University of Michigan Law School

University of Michigan Law School Scholarship Repository

Articles

Faculty Scholarship

1986

\title{
The Supreme Court and State Protectionism: Making Sense of the Dormant Commerce Clause
}

Donald H. Regan

University of Michigan Law School, donregan@umich.edu

Available at: https://repository.law.umich.edu/articles/344

Follow this and additional works at: https://repository.law.umich.edu/articles

Part of the Constitutional Law Commons, Courts Commons, Legislation Commons, State and Local Government Law Commons, and the Supreme Court of the United States Commons

Recommended Citation

Regan, Donald H. "The Supreme Court and State Protectionism: Making Sense of the Dormant Commerce Clause." Mich. L. Rev. 84 (1986): 1091-287.

This Article is brought to you for free and open access by the Faculty Scholarship at University of Michigan Law School Scholarship Repository. It has been accepted for inclusion in Articles by an authorized administrator of University of Michigan Law School Scholarship Repository. For more information, please contact mlaw.repository@umich.edu. 


\title{
THE SUPREME COURT AND STATE PROTECTIONISM: MAKING SENSE OF THE DORMANT COMMERCE CLAUSE
}

\author{
Donald H. Regan* \\ for Eric Stein
}

This essay was originally intended for the Michigan Law Review's recent Festschrift for Eric Stein. In the end, the essay was too long and too late. But even as a straggler, I wish to pay tribute to an admired and loved colleague. The Festschrift, marking Eric's retirement, appeared prematurely anyway. Eric has not retired, except in the myopic view of the bureaucrats, and shows no signs of doing so.

\section{TABle of CoNTENTS}

I. INTRODUCTION ............................. 1092

A. The Temporal Scope of the Thesis .............. 1093

B. What Is "Protectionism"? ..................... 1094

C. What Are "Movement-of-Goods" Cases? How and Why Are They a Doctrinally Significant Class? ..... 1098

D. What Is "Balancing"? ....................... 1101

E. The Arguments Ahead, and the Connections Between Them .................................. 1108

II. Theory: What The Court Should Do .......... 1110

A. The Case Against Protectionism, and the Primacy of Purpose ................................ 1110

B. In Praise of Motive Review, Particularly Under the Dormant Commerce Clause .................... 1143

C. Against the Carolene Products Theory of the Dormant Commerce Clause and Open-Ended Private Interest Balancing ......................... 1160

D. Interlude: Variations on the Theme of AntiProtectionism............................. 1167

E. The Irrelevance of National Interest Balancing to Movement-of-Goods Cases ...................... 1174

* Professor of Law and Professor of Philosophy, University of Michigan. B.A. 1963, Harvard University; LL.B. 1966, University of Virginia; M.Phil. (Economics) 1968, Oxford University; Ph.D. (Philosophy) 1980, University of Michigan. - Ed. I am grateful to Alex Aleinikoff, Vince Blasi, Terry Sandalow, and Fred Schauer for very helpful criticism of various drafts; also to the Guggenheim Foundation, which thought it was supporting something else. 
F. National Interests in Transportation Cases, Taxation Cases, and Maybe Some Others............... 1182

G. The State as Market Participant and Related Matters .......................... 1193

H. The Anti-Protectionism Principle and the Privileges and Immunities Clause ..................... 1202

III. Practice: What The Court Is DoIng ............ 1206

A. The Leading Precedents for Balancing: Pike, Hunt, and Dean Milk .......................... 1209

B. A Selection of Cases Upholding State Laws: Exxon, Clover Leaf, Breard, and Commonwealth Edison ... 1233

C. "Golden Oldies": Baldwin, Henneford, Eisenberg, Hood, et al. ............................. 1245

D. A Post-Pike Survey: Filling in the Gaps ......... 1268

E. Why Does the Court Not Preach What It Practices? .................................... 1284

\section{INTRODUCTION}

For almost fifty years, scholars have urged the Court to "balance" in dormant commerce clause cases; and the scholars have imagined that the Court was following their advice. ${ }^{1}$ The Court has indeed claimed to balance, winning scholarly approval. But the Court knows better than the scholars. Despite what the Court has said, it has not been balancing. It has been following a simpler and better-justified course.

In the central area of dormant commerce clause jurisprudence, comprising what I shall call "movement-of-goods" cases (Pike v. Bruce Church, Inc. ${ }^{2}$ may be taken as paradigmatic), the Court has been concerned exclusively with preventing states from engaging in purposeful economic protectionism. Not only is this what the Court has been doing, it is just what the Court should do. This and no more.

In cases other than movement-of-goods cases - cases involving regulation of railroads or highways, cases about taxation - the Court has had certain limited goals over and above preventing protectionism. Indeed, in cases dealing specifically with regulation of the transporta-

1. E.g., Blasi, Constitutional Limitations on the Power of States to Regulate the Movement of Goods in Interstate Commerce, in 1 CourTs AND FREE MARKETS: PERSPECTIVES FROM THE UNITED STATES AND EUROPE 174 (T. Sandalow \& E. Stein eds. 1982); Brown, The Open Economy: Justice Frankfurter and the Position of the Judiciary, 67 YALE L.J. 219 (1957); Dowling, Interstate Commerce and State Power, 27 VA. L. REV. 1 (1940); Henkin, Infallibility Under Law: Constitutional Balancing, 78 CoLUM. L. REv. 1022, 1037-41 (1978).

2. 397 U.S. 137 (1970). 
tion system, the Court may even engage in a very particular balancing task. But in no area has the Court engaged in the sort of open-ended balancing the scholars have recommended.

In this essay, I shall concentrate on the movement-of-goods area. The claim I am most concerned to establish is my claim that in this area the Court is concerned and should be concerned only with preventing purposeful protectionism. In fact, the discussion in Part III of what the Court is doing will be limited almost entirely to the movement-of-goods area. In Part II, where I discuss what the Court should be doing, it is again the movement-of-goods area that interests me most; but the argument establishing that, in this area, the Court should be concerned only with preventing protectionism will reveal quite naturally why certain other areas involve additional, but always limited and specific, judicial tasks. ${ }^{3}$

\section{A. The Temporal Scope of the Thesis}

That part of my thesis which is about what the Court is actually doing is meant to apply only to the modern era of dormant commerce clause jurisprudence. The modern era is defined by the abandonment

3. (A bibliographic note situating my claims in the literature.) In the last few years a number of scholars have argued that under the dormant commerce clause the courts should be concerned only with preventing discrimination by one state against other states or against interstate commerce. Black, Perspectives on the American Common Market, in Regulation, Federalism, AND INTERSTATE COMMERCE 59 (A. Tarlock ed. 1981); Maltz, How Much Regulation Is Too Much - An Examination of Commerce Clause Jurisprudence, 50 GEo. WASH. L. REv. 47 (1981); Sedler, The Negative Commerce Clause as a Restriction on State Regulation and Taxation: An Analysis in Terms of Constitutional Structure, 31 WAYNE L. REV. 885 (1985); Smith, State Discriminations Against Interstate Commerce, 74 CALIF. L. REv. (forthcoming). Even the relevant chapter in G. GUNTHER, CONSTITUTIONAL LAw (11th ed. 1985), has been reorganized to give the anti-discrimination theme greater prominence.

None of these authors, to my mind, gives a really clear account of what "discrimination" means in the dormant commerce clause context. Aside from that, my own position goes well beyond the trend these articles represent in at least three respects: (1) in my view protectionism (or discrimination in the relevant sense) is primarily a matter of legislative purpose; (2) I claim that the Court has in fact recognized this implicitly, that bad purpose is what the Court has been attending to in the central line of cases; and (3) I attach much greater importance than other commentators do to the distinction between movement-of-goods cases and other sorts of cases. (Maltz sometimes appears to share my view about the theoretical importance of purpose, but he is not willing to be as definite about it as I am. Indeed, Maltz' article contains many insights, but it lacks an adequate theoretical structure.)

There has been another significant recent development in dormant commerce clause scholarship: a spate of articles advancing what I call the "Carolene Products theory of the dormant commerce clause" (which others might call the process theory or the representation-reinforcing theory). I shall cite the main articles and discuss the theory (and why I reject it) in Part II.C. I mention this development here because it might occur to some readers that the Carolene Products theory also refiects a heightened concern with discrimination. That is true in a sense. But in fact the Carolene Products theory of the dormant commerce clause, even if it starts from an antidiscrimination premise of a sort, ends up being appealed to in support of balancing. So the thrust of this development is really quite different from that of the development summarized in the first paragraph of this note. 
of the "direct/indirect burdens" test and therefore cannot be given a precise beginning date. The direct/indirect test was criticized by Justice Stone in dissent in 1927.4 Cases were decided in the 1930 s that paid only lip service to the test. ${ }^{5}$ An important article criticizing the test was published by Professor Noel Dowling in $1940 .^{6}$ Finally, a new balancing approach was announced by then Chief Justice Stone for the Court in $1945 .^{7}$ This was the coup de grâce. Note that to say it was Stone who finally dispatched the direct/indirect test is not yet to accept his description of what replaced it. By 1945, then, the direct/ indirect test was dead, except in the area of state taxation of interstate commerce, where it hung on a bit longer. ${ }^{8}$ I shall discuss no case from before 1935. If my thesis holds good for the modern era, we can reasonably assume that old cases inconsistent with the thesis are no longer significant precedents. ${ }^{9}$

\section{B. What Is "Protectionism"?}

First off, when I say the dormant commerce clause forbids states from engaging in protectionism, I mean protectionism directed at other states. The commerce clause restrains the states also in their powers with regard to international trade, but the commerce clause is not the only clause relevant to that, nor has international trade figured largely in dormant commerce clause jurisprudence. International trade will not concern us in this essay.

The quintessential instrument of protectionism is the protective tariff, a duty on imports of a certain good imposed for the purpose of securing a greater share of the home market for domestic producers of the good. Heuristically, we can think of my definition of protectionism, given in the next paragraph, as simply a generalization from this paradigm case.

I shall say that a state statute (or administrative regulation, or local ordinance, or whatever) is protectionist if and only if:

(a) the statute (or whatever) was adopted for the purpose of improving the competitive position of local (in-state) economic actors,

4. Di Santo v. Pennsyivania, 273 U.S. 34, 43 (1927) (Stone, J., dissenting).

5. E.g., Baldwin v. G.A.F. Seelig, Inc., 294 U.S. 511 (1935); Milk Control Bd. v. Eisenberg Farm Prods., 306 U.S. 346 (1939).

6. Dowling, supra note 1 .

7. Southern Pac. Co. v. Arizona ex rel. Sullivan, 325 U.S. 761 (1945).

8. E.g., Freeman v. Hewit, 329 U.S. 249 (1946); see Hellerstein, Federal Limitations on State Taxation of Interstate Commerce, in 2 CouRTS AND FREE MARKETS, supra note 1, at 440-41.

9. Cf. the treatment of Public Utils. Commn. v. Attleboro Steam \& Elec. Co., 273 U.S. 83 (1927), in Arkansas Elec. Coop. v. Arkansas Pub. Serv. Commn., 461 U.S. 375 (1983). 
just because they are local, vis-à-vis their foreign (by which I mean simply out-of-state) competitors; and

(b) the statute (or whatever) is analogous in form to the traditional instruments of protectionism - the tariff, the quota, or the outright embargo (all of which can be on imports or exports).

The doctrine that states may not engage in protectionism (may not adopt protectionist legislation as I have defined it) I shall refer to as the "anti-protectionism principle."

The anti-protectionism principle has obvious historical roots, and that is part of what recommends it. But there is also a nonhistorical, theoretical case to be made for the anti-protectionism principle. The main body of that case, concerned with justifying part (a) of my definition, is set out in section II.A. below. Part (b) of the definition, which may seem more ad hoc, is necessary in part to account for the Court's recent decisions on the state-as-market-participant; but it is necessary for other reasons as well, and it has its own theoretical justification, which is discussed in section II.G. As it happens, all the state laws involved in what the reader would think of as standard cases under the dormant commerce clause satisfy part (b) of the definition, and the reader would do well to forget about part (b) until I remind her of it. Part (a) is what is central.

The aspect of my definition of protectionism that is most to be emphasized is this: for a statute to be protectionist, it must have a protectionist purpose. We can of course define the phrase "protectionist effect," and it will be useful to do so: a protectionist effect is any improvement (caused by the statute) in the competitive position of some class of local economic actors vis-à-vis their foreign competitors. But protectionist effect does not make a statute protectionist under my definition; nor does protectionist effect have any constitutional significance in itself. The Court both is and should be concerned with purpose. Protectionist effect is significant evidence on the issue of protectionist purpose; but it is just that, evidence and no more.

I shall explain why purpose is central as part of the general analysis of protectionism in section II.A. By recommending judicial inquiry into legislative purpose, $I$ raise the broader issue of what has come to be known as motive review, which I shall discuss in section II.B.

A further important feature of my definition of protectionism is this: not just any purpose to advantage local economic actors at the expense of foreign actors is protectionist. The purpose must be to advantage local actors at the expense of their foreign competitors. (Similarly, protectionist effect is defined as an improvement in the competitive position of local actors vis-à-vis foreign competitors.) 
From the point of view of economic theory, producers compete with producers (both as purchasers of inputs to the production process and as sellers of goods), workers compete with workers, distributors compete with distributors, consumers compete with consumers, and so on. (The fact that consumers compete with other consumers means, incidentally, that laws seeking the competitive advantage of local consumers vis-à-vis their foreign consumer competitors come within my definition of protectionism. They may not come within the standard historical notion of protectionism. Whether the anti-protectionism principle ought to extend to such consumer protectionism is a topic I shall discuss briefly in sections II.A. and II.D.)

Of course, to be competitors actors need not be alike in every respect. If the statute about milk containers that was upheld in Minnesota v. Clover Leaf Creamery Co. ${ }^{10}$ had been passed for the purpose of diverting business from foreign producers of plastic resins to local producers of wood pulp, it would have been protectionist on my definition. Plastic resins and wood pulp compete, derivatively but genuinely, in the market for milk containers. Also, an actor may occupy more than one role and may, for example, compete both with producers (as a producer) and with distributors (as a distributor).

But producers (as such) do not compete with distributors (as such) or with consumers (as such). Thus the scheme upheld in Parker $v$. Brown, ${ }^{11}$ for example, which advantaged local growers of raisins at the expense of (mostly foreign) distributors and consumers, was not protectionist in purpose or in effect.

The reader may wonder why a purpose to favor local actors at the expense of foreign actors is constitutionally permissible provided the foreign actors are not the locals' competitors. I shall address this question in due course. History is justification enough for taking as our starting point for analysis a definition of protectionism that focuses on injury to competitors. I shall assume through sections II.A. and II.B. that injury to competitors is part of what we mean by protectionism. In sections II.C. and II.D. I shall consider whether we should relax that restriction in any way.

Three final points will conclude this section:

(1) Notice that being against protectionism as I have defined it is not at all the same thing as being in favor of total economic laissezfaire. Many sorts of regulation are inconsistent with laissez-faire that are not protectionist and that are therefore permitted by my theory.

10. 449 U.S. 456 (1981).

11. 317 U.S. 341 (1943). 
The scheme in Parker v. Brown, which I mentioned just a moment ago, is an example. The tendency to conflate opposition to protectionism with commitment to laissez-faire is encouraged by the ambiguity of the phrase "free trade," which is commonly used both as an antonym for protectionism and as a synonym for laissez-faire. But in these two usages, the phrase "free trade" just has two different meanings. I shall say more later on about the difference between being against protectionism and favoring laissez-faire; but I mention it now because failure to appreciate the distinction could occasion serious misunderstanding. ${ }^{12}$

(2) Notice also that my definition of protectionism speaks of a purpose to improve the competitive position of local economic actors. A law may be protectionist under my definition even though it does not aim at putting local actors in a better competitive situation than their foreign competitors. All that is necessary for the law to be protectionist is that it aim at putting local actors in a better competitive situation (vis-à-vis their foreign competitors) than they would have enjoyed without the law. Imagine a law that aims only at eliminating some (independently existing) competitive disadvantage suffered by local actors. This law has a protectionist purpose. It cannot be defended by saying it aims only at putting local actors and their foreign competitors on a footing of competitive equality.

For convenience, I shall refer to this point by saying that a law may be protectionist even though it does not aim at securing for local actors an "absolute" competitive advantage. "Absolute" reflects the "better situated than foreign competitors" goal, which is not essential to protectionism, as opposed to the "better situated than in the absence of the law" goal, which is essential.

Perhaps confusion about the point I have just made is unlikely but this point is related to another point that I think has caused confusion. The new point is about the connection between protectionism and "local preference." I shall sometimes speak of protectionism as essentially involving local preference; I shall sometimes say that because a law does not involve local preference, it has no protectionist purpose. But "preference" is ambiguous. So let me clarify my meaning. One might say that a law manifested local preference only if it "created a preference" for local actors, in the sense of giving locals an

12. Consider Eule, Laying the Dormant Commerce Clause to Rest, 91 YALE L.J. 425, 425-35 (1982), who in the process of arguing correctly that the Constitution does not incorporate laissezfaire appears also to say, as if it were the same thing, that the Court should not concern itself with state protectionism. But Eule does not doubt the Court should suppress protectionism in my sense. Indeed, as a Carolene Products theorist (see Part II.C. infra) he wants the Court to do even more than that. 
absolute competitive advantage. Obviously, that is not the way I use "preference," since I have just said both (a) that to be protectionist a law must involve local preference, and (b) that a law may be protectionist even though it does not aim at giving locals an absolute competitive advantage. What I shall mean by "local preference" is just a purpose to promote the interests of local actors as such, in preference to the interests of foreign actors. In this sense, local preference is manifested by a law which aims at no absolute competitive advantage for locals, but which purposefully removes some competitive disadvantage suffered by locals. This sense of preference (my sense) is broader than the absolute-advantage sense. If there is no local preference in my sense, then indeed there is no protectionist purpose. I shall suggest much further on that confusion about these two meanings of "preference" may contribute to the difficulty many people have in seeing the difference between Baldwin v. G.A.F. Seelig, Inc. ${ }^{13}$ (in which there is no preference in the absolute-advantage sense but there is reason to presume local preference in the broader sense) and Henneford v. Silas Mason Co. ${ }^{14}$ (in which there is no preference in either sense). ${ }^{15}$

(3) Notice finally that even though we adopt my purpose-based anti-protectionism principle as the proper doctrinal embodiment of our concern about protectionism, we are not thereby committed to thinking that courts should sift the evidence looking for purpose case by case without the help of per se rules or evidentiary presumptions. I think the Court both should use and does use some per se rules or presumptions in its search for protectionist purpose. The Court does not always explain adequately the basis for the per se rules or presumptions it uses; but we shall see that the per se rules or presumptions the Court uses can be justified by a purpose-based theory, and are in fact better justified by a purpose-based theory than by any other. So the Court's use of per se rules or presumptions casts no doubt on my descriptive claim that the Court not only should be concerned with purpose, but is so concerned.

\section{What Are "Movement-of-Goods" Cases? How and Why Are They a Doctrinally Significant Class?}

The class of movement-of-goods cases is defined by exclusion. Movement-of-goods cases are all dormant commerce clause cases except: (1) cases involving state regulation of the instrumentalities of

13. 294 U.S. 511 (1935).

14. 300 U.S. 577 (1937).

15. In the Appendix to section III.C., I discuss, inter alia, the views on Henneford of Ernest Brown and Walter Hellerstein. 
interstate transportation, such as railroads or trucking; ${ }^{16}(2)$ cases involving state taxation of interstate commerce; and (3) cases involving the state as market participant (Hughes v. Alexandria Scrap Corp. ${ }^{17}$ and its progeny).

These are substantial exclusions, but they are not arbitrary. What is left after these exclusions is what most people would regard as the central line of dormant commerce clause cases in the modern era, running from Baldwin v. G.A.F. Seelig, Inc. ${ }^{18}$ through H.P. Hood \& Sons v. Du Mond, ${ }^{19}$ Dean Milk Co. v. City of Madison, ${ }^{20}$ and Breard v. Alexandria, ${ }^{21}$ on through Pike v. Bruce Church, Inc., ${ }^{22}$ right up to Hunt v. Washington State Apple Advertising Commission, ${ }^{23}$ Exxon Corp. v. Maryland, ${ }^{24}$ Philadelphia v. New Jersey, ${ }^{25}$ and Minnesota v. Clover Leaf Creamery $\mathrm{Co}^{26}$ Cases such as these are what I call movement-ofgoods cases.

My central thesis, as I mentioned earlier, is that in movement-ofgoods cases what the Court should do and is doing is to prevent state protectionism. That and no more. What makes movement-of-goods cases special is not that the anti-protectionism principle applies to them. Rather, what makes movement-of-goods cases special is that in them the anti-protectionism principle exhausts the grounds for judicial review under the dormant commerce clause.

The anti-protectionism principle applies to all dormant commerce clause cases. State regulations of the instrumentalities of transportation or state taxes on commerce will be struck down if they violate the anti-protectionism principle. Somewhat more broadly (since "the anti-protectionism principle" refers specifically to my own version of the more general idea that states should not be allowed to discriminate against interstate commerce), whatever form the no-discriminationagainst-interstate-commerce principle takes, there is no reason to

16. E.g., Kassel v. Consolidated Freightways Corp., 450 U.S. 662 (1981); Southern Pac. Co. v. Arizona ex rel. Sullivan, 325 U.S. 761 (1945). Cases involving airlines, pipelines, communications facilities, and the like would count too, but apparently these instrumentalities are so thoroughly regulated by federal law that challenges to state laws tend to generate preemption cases, not commerce clause cases.

17. 426 U.S. 794 (1976).

18. 294 U.S. 511 (1935).

19. 336 U.S. 525 (1949).

20. 340 U.S. 349 (1951).

21. 341 U.S. 622 (1951).

22. 397 U.S. 137 (1970).

23. 432 U.S. 333 (1977).

24. 437 U.S. 117 (1978).

25. 437 U.S. 617 (1978).

26. 449 U.S. 456 (1981). 
think it less applicable to cases involving transportation or taxation than to movement-of-goods cases. On a different tack, it might seem that acts by the state as market participant are not subject to the antiprotectionism principle, since purposefully discriminatory market behavior by the state may be upheld. But even that is consistent with the anti-protectionism principle. Actions of the state as market participant are put outside the scope of the principle's prohibition by part (b) of my definition of protectionism. ${ }^{27}$

So, being subject to the anti-protectionism principle is something movement-of-goods cases have in common with all other cases. What is distinctive about movement-of-goods cases is that protectionism is the only issue they present. Once we have decided a movement-ofgoods statute is not protectionist, that is the end of the matter. The statute should be upheld. There is nothing else to consider and no balancing to be done. In transportation cases and taxation cases, however, a decision that the statute is not protectionist does not end the matter. There are further issues to consider.

Why is there this difference between movement-of-goods cases and transportation or taxation cases? Schematically put, the reason is this. Dormant commerce clause review protects various national interests against damage from state legislation. One national interest, which may be involved in any sort of dormant commerce clause case, is the national interest in avoiding state protectionism. As it happens, this is the only national interest involved in movement-of-goods cases. ${ }^{28}$ That is why, once we have decided there is no protectionism in some movement-of-goods case, we are done. In contrast, there are other national interests that may be involved in transportation or taxation cases. ${ }^{29}$ Hence, the anti-protectionism principle does not exhaust the appropriate grounds for review in those cases.

Three minor points remain:

First, in case it earlier seemed paradoxical that I should offer the tarriff, which is a form of tax, as the paradigm of protectionism, and should then exclude taxation cases from the range of cases (the movement-of-goods cases) that are the subject of my central thesis, the reso-

27. See section II.G. infra. Strictly speaking, the state-as-market-participant cases are like the movement-of-goods cases in the respect that the anti-protectionism principle exhausts the appropriate grounds of commerce clause review. The state-as-market-participant cases differ, however, in involving the special issue of what counts as being a market participant - or more precisely, the issue of what sort of behavior is allowed despite protectionist motive by part (b) of my definition of protectionism. It is therefore most satisfactory for heuristic purposes to define movement-of-goods cases as excluding cases on the state as market participant, especially if we want the movement-of-goods cases to be the generally recognized central line of cases.

28. See sections II.C., II.D., and especially II.E. infra.

29. See section II.F. infra. 
lution of that paradox should now be obvious. Because the antiprotectionism principle applies to taxation, there is no oddity in a tax being one of the paradigm cases of protectionism. In fact, the special feature of tax cases that makes it necessary to split them off as a category from movement-of-goods cases happens not to be relevant to tariffs at all.

Second, in case it occurs to any reader to wonder, I do not treat as a special category cases involving state attempts to give their own citizens preferred access to local natural resources (for example, Pennsylvania v. West Virginia ${ }^{30}$ or Hughes v. Oklahoma ${ }^{31}$ ). Cases about natural resources may, because of further special features, fall into any of the three exclusions from the movement-of-goods category that I have defined; but if they do not, they are treated as ordinary movement-of-goods cases. I shall say a few words in sections II.A. and II.D. about why that treatment is appropriate.

Finally, I see no need to break the class of movement-of-goods cases down further, into cases on incoming commerce versus outgoing commerce, cases where the local goal is health or safety versus cases where the local goal is economic (but nonprotectionist), or whatever. What the Court should do and is doing does not depend on any such distinctions.

\section{What Is "Balancing"?}

I have used "balancing" as a generic term to refer to all the things the Court should not and does not do, but which other commentators have thought the Court either should or does do. I must now be more precise about the variety of possible judicial approaches I mean to reject. The distinctions I shall make between variants of balancing really ought to have been introduced into the literature by some proponent of balancing, but so far as I am aware they have not been. ${ }^{32}$

I shall distinguish "open-ended private interest balancing," "national interest balancing," and "protectionist effect balancing" (which comes in two subspecies). I shall also mention some further approaches that do not really involve balancing in any sense but that have more the feel of balancing than of my purpose-based approach

30. 262 U.S. 553 (1923).

31. 441 U.S. 322 (1979).

32. Blasi, supra note 1 , at $185-87$, may be the only balancer who even recognizes the need for clarification of what balancing means. (Henkin, supra note 1 , has usefully distinguished balancing as a mode of constitutional interpretation from balancing as constitutional doctrine, that is, as a constitutionally mandated mode of deciding individual cases; but that still leaves the problem of what precisely balancing as a mode of deciding individual cases comes to. It is that problem I now address.) 
and that therefore recommend themselves to some people who are particularly anxious to avoid motive review.

(1) The sort of balancing I am most concerned to deny, in both my prescriptive and descriptive theses, is what I shall call "open-ended private interest balancing." Open-ended private interest balancing has its proponents in most areas of constitutional law, and it wears a variety of theoretical disguises, but in essence the open-ended private interest balancer is the person who thinks that any cost imposed by a statute on any private party can be advanced as an argument against the constitutionality of the statute (not just against the wisdom of the statute). The open-ended private interest balancer recognizes that not just any cost to a private party is enough to invalidate a statute, but he thinks that all such costs count. They all deserve some weight in the balance. They all give rise to a need for legislative justification, which it is up to the courts to see is present.

In the context of the dormant commerce clause, the open-ended private interest balancer concentrates on costs imposed on economic actors and mediated by economic relationships. He may also think that some costs to foreign (out-of-state) actors must be shown in order to trigger judicial review. But once review is triggered, all private costs anywhere are normally treated as relevant.

Let us have an example. In 1971, the State of Oregon enacted the nation's first statute designed to protect the environment by discouraging the use of nonreturnable, nonreusable beverage containers. ${ }^{33}$ The statute imposed a specified refundable deposit on beverage containers, repayable by retailers to consumers and by distributors to retailers upon return of the container. Lower deposits could be authorized administratively for containers accepted for reuse by more than one manufacturer. "Pull-top" metal cans were flatly prohibited. These provisions of the statute tended to encourage the use of glass bottles instead of metal cans. Since bottles are heavier than cans, and since reusable containers need to be transported both to the consumer and back to the bottler, the statutory scheme increased transportation costs. This tended to favor Oregon bottlers over foreign bottlers.

Opponents of the Oregon bottle law argued that it was unconstitutional under the dormant commerce clause on a number of grounds. First, they argued that the law was passed for the purpose of advantaging Oregon bottlers at the expense of foreign bottlers. ${ }^{34}$ This is a perfectly appropriate argument, in my view; but the Oregon Court of

33. The statute was upheld in American Can Co. v. Oregon Liquor Control Commn., 15 Or. App. 618, 517 P.2d 691 (1973).

34. 15 Or. App. at $638-39,517$ P.2d at 701 , especially n.6. 
Appeals rejected the factual premise. The court found that there was no protectionist purpose. ${ }^{35}$ Opponents of the law also argued, at least implicitly, that because of the protectionist effect of the statute, the court should inquire whether there were good effects from the statute sufficient to justify the protectionist effect. This argument is a call for protectionist effect balancing, which I shall consider in a moment.

Finally, the opponents of the statute pointed to all sorts of economic costs to individuals, both within and without Oregon, that would result from the enforcement of the statute. ${ }^{36}$ Canning companies (both local and foreign) complained that they would lose substantial business. Can manufacturers likewise. Even bottle manufacturers complained that they would sell fewer bottles if the bottles they sold had to be reusable. Brewers (foreign) complained that their Oregon sales would be reduced and that the price of beer would be elevated. Soft drink manufacturers complained that the growth of their industry would be curtailed. These dire predictions were summed up in the claim that the Oregon bottle law would require the reorganization of an entire national distribution scheme, especially if other states followed Oregon's example.

The arguments summarized in the last paragraph are the arguments of the open-ended private interest balancer. They are arguments fully meet for legislative consideration. They are also, as the Oregon court implicitly recognized, constitutionally irrelevant.

Before 1937, the open-ended private interest balancer could make his arguments against economic regulation under the rubric of economic due process. At present, the principal theoretical defense of open-ended private interest balancing is what I shall refer to as "the Carolene Products theory of the dormant commerce clause." The central idea of the Carolene Products theory of the dormant commerce clause is that the courts should supervise state economic regulation in order to guarantee that out-of-state interests, which are unrepresented in the legislature that produced the regulation, are fairly treated. I shall explain in section II.C. why the Carolene Products theory of the dormant commerce clause is unacceptable. To be sure, one particular mode of unfair treatment of foreign interests, namely purposeful protectionism, is constitutionally forbidden. But we shall see that forbidding purposeful protectionism is a far cry from imposing a general requirement of fair treatment for foreign interests.

(2) Another type of balancing suggested by much of the rhetoric

35. 15 Or. App. at 639 n.6, 644, 517 P.2d at 701 n.6, 703.

36. 15 Or. App. at $625-27,517$ P.2d at 695-96. 
surrounding the dormant commerce clause is "national interest balancing." The basic idea here is that state regulation may interfere with certain interests of the nation as a whole (as opposed to mere private interests), and that if it does so interfere, then judicial inquiry into the justification for the interference is appropriate. The national interests most commonly asserted in movement-of-goods cases, in addition to the interest in avoiding state protectionism, are interests in economic union, in the free movement of goods throughout the country, in access to markets, in uniformity of commercial regulation, and in efficiency.

It is easy to slide in argument from a premise of national interest balancing to a practical application that amounts to open-ended private interest balancing. It is easy, for example, to treat the claimed national interest in access to markets as if it were fully embodied in the private interests of foreign producers (say beer can manufacturers) who want to be allowed to sell in a market from which some statute (say the Oregon bottle law) excludes them. Despite the ease of this slide from national interest balancing to private interest balancing, there is a distinction in principle that is worth keeping in mind.

Now, I do not reject national interest balancing out of hand, as I reject open-ended private interest balancing. To the extent there are genuine national interests threatened by some form of state regulation, and to the extent the protection of such genuine national interests requires balancing, national interest balancing makes sense.

However, there is no place for national interest balancing in movement-of-goods cases. As I have mentioned previously, there is only one genuine national interest threatened by state regulation of the movement of goods, and that is the interest in avoiding state protectionism. That interest does not require balancing, however. It is properly protected by judicial inquiry into legislative purpose. Laws with protectionist purpose are invalid (leaving aside cases of the state as market participant); laws without protectionist purpose (and regulating the movement of goods, remember) are valid. No balancing required. As to the other national interests that are regularly asserted in movement-of-goods cases - interests in economic union, in the free movement of goods, and so on - we shall see in section II.E. that these are either identical to the interest in avoiding protectionism or they are not genuine national interests at all.

In transportation and taxation cases, there are genuine national interests other than the interest in avoiding state protectionism. As it happens, the national interest peculiar to tax cases does not require balancing for its protection; but the national interest peculiar to trans- 
portation cases does. So there is at least one area where national interest balancing is genuinely appropriate. ${ }^{37}$

(3) Now, as to protectionist effect balancing. The basic idea is simple enough: if the statute has a protectionist effect (that is, if its effect is to improve the competitive position of some local economic actors vis-à-vis their foreign competitors), then the court must look to see whether it also has good effects adequate to justify the (bad) protectionist effect. Something like this seems to be the Court's currently favored official test. There are, however, three different possible lines of argument in justification of protectionist effect balancing, and there are two different formulations of the test to be found in the opinions of the Court.

Let us look first at the supposed justifications. The first possibility is that protectionist effect balancing is a limited version of private interest balancing. On this view, private costs imposed by the statute are what the court ought to weigh in the balance against the statute, but for some reason only the private costs associated with the existence of protectionist effect deserve consideration. This will not do. Not only is there no justification for private interest balancing of any kind under the dormant commerce clause; 38 but even if private interest balancing were appropriate, there would be no reason, or at least no reason from within the standard theories that call for private interest balancing, for thinking that private costs associated with protectionist effect have any special significance.

The next possibility is that protectionist effect balancing is a version of national interest balancing. This justification of protectionist effect balancing requires the premise that there is a national interest in the avoidance of protectionist effect (even absent protectionist purpose), or, in other words, that protectionist effect is a constitutional disvalue in itself. But we shall see in section II.A. that protectionist effect is not a constitutional disvalue in itself. ${ }^{39}$ So this justification of protectionist effect balancing also fails.

Finally, we might engage in protectionist effect balancing, not because of the constitutional disvalue of protectionist effect or the private costs associated with it, but simply as a means of smoking out protectionist purpose. Protectionist purpose is constitutionally objectionable (except in special cases), and protectionist effect is always some evidence (though often very weak evidence) of protectionist pur-

37. See section II.F. infra.

38. See section II.C. infra.

39. See especially subsection II.A.2. infra. 
pose. If we distrust the courts' ability to ascertain legislative purpose, or if we think inquiry into purpose is improper for some other reason, we might recommend protectionist effect balancing as a rule of decision that would approximate the results of successful inquiry into purpose while avoiding some of the attendant problems.

For myself, I see no well-founded objection to judicial review of legislative purpose, at least in the dormant commerce clause area..$^{40} \mathrm{I}$ therefore think there is no need for protectionist effect balancing. I also think that the Court is not engaged in protectionist effect balancing, despite the appearance of versions of the idea in various opinions. But this much I will say in favor of protectionist effect balancing. If we must have some form of balancing (which I deny), then protectionist effect balancing as a stand-in for purpose inquiry is by far the most defensible. Furthermore, if the Court is engaged in any sort of balancing (which I also deny), then protectionist effect balancing is what it is engaged in.

I have mentioned that the Court has produced two formulations of protectionist effect balancing. What I shall call "strict" protectionist effect balancing is represented by the following quotation from Chief Justice Burger's opinion in Hunt v. Washington State Apple Advertising Commission:

When discrimination against commerce of the type we have found [i.e., protectionist effect] is demonstrated, the burden falls on the State to justify it both in terms of the local benefits flowing from the statute and the unavailability of nondiscriminatory alternatives adequate to preserve the local interests at stake. ${ }^{41}$

Another possibility that is much more favorable to the state and that I shall call "weak" protectionist effect balancing appears in Justice Stewart's famous opinion in Pike v. Bruce Church, Inc.:

Where the statute regulates evenhandedly to effectuate a legitimate local public interest, and its effects on interstate commerce are only incidental, it will be upheld unless the burden imposed on such commerce [i.e., the protectionist effect] is clearly excessive in relation to the putative local benefits. ${ }^{42}$

The immediate context of this quote from Stewart does not indicate (as the immediate context of the quote from Burger does) that the only sort of burden on commerce Stewart has in mind is protectionist effect. But the opinion as a whole makes it clear that protectionist effect is the only sort of burden Stewart saw in Pike. ${ }^{43}$ In any event, there is no

40. See section II.B. infra.

41. 432 U.S. 333,353 (1977).

42. 397 U.S. 137, 142 (1970) (emphasis added).

43. See the extended discussion of Stewart's opinion in section III.A. infra. 
doubt that protectionist effect is included among the burdens Stewart has in mind (if they are in fact plural), so the weak "clearly excessive" standard is meant by Stewart to apply where there is protectionist effect. That is the main point of interest at present.

As a stand-in for purpose inquiry, strict protectionist effect balancing seems too strict. To say that a state legislature whose act causes protectionist effect should be assumed to have acted with bad purpose unless the Court in a de novo balancing regards the value of the good effects actually achieved as at least equal to the disvalue of the protectionist effect presupposes an extremely skeptical view of state legislatures' likely motives.

Weak protectionist effect balancing, because it is skewed in favor of the state, is a more plausible stand-in for purpose inquiry. And so, I think that if the Court is engaged in any sort of protectionist effect balancing at all, it is engaged in weak protectionist effect balancing. In the end, though, I think the Court is not engaged in protectionist effect balancing of any kind. It is engaged in purpose review, as I shall show in Part III.

Incidentally, Burger's formulation of strict protectionist effect balancing makes reference to less restrictive alternative analysis, and so does a later sentence of the passage in Stewart's opinion that I quoted from. ${ }^{44}$ Less restrictive alternative analysis can itself be part of an indirect approach to the question of legislative purpose. ${ }^{45}$ Otherwise, it is simply a wrinkle in whatever balancing test it is joined to, a form of balancing at the margin. If there is no balancing, there will be no less restrictive alternative analysis. The less restrictive alternative idea therefore requires no systematic treatment in this essay. It will pop up from time to time as we discuss other things.

(4) I said at the beginning of this section that I would mention some other approaches that do not involve balancing but that have some similarity to balancing and that might recommend themselves to people anxious to avoid motive review.

One such possibility is to inquire simply into whether the state statute under review has any good effects, without attempting to quantify them, evaluate them, or compare them to supposed bad effects on commerce. If the statute has any good effects, it is upheld. This minimalist version of effects review may represent the Court's actual decision process in some of the transportation cases; ${ }^{46}$ but we are not

\footnotetext{
44. 397 U.S. 137, 142 (1970).

45. Cf. the extended discussion in section III.A. infra of Burger's opinion in Hunt.

46. See section II.F. infra.
} 
primarily concerned with how the Court has decided those cases. I shall argue in section II.A. that even this minimalist approach has no justification in the movement-of-goods area, except to the extent that looking for good effects is part of an inquiry into purpose.

Another possible approach is what I shall call the "hypothetical innocent legislature test." Admitting that protectionist purpose is what we really object to, but recoiling from open review of legislative purpose, the court might undertake to ask itself, "Is it plausible to suppose that a state legislature might have passed this law without being motivated by protectionist purpose?" The inadequacy of this superficially appealing subterfuge is explained in section II.B.

\section{E. The Arguments Ahead, and the Connections Between Them}

The remainder of this essay is in two parts. Part II contains a reasonably complete discussion of dormant commerce clause theory, not limited to movement-of-goods cases. I have already mentioned most of the sections of Part II in the course of the Introduction. There are two items I have not had occasion to mention. Congress' power to authorize state protectionism will be discussed (along with much else) in section II.A. ${ }^{47}$ and the relation of the anti-protectionism principle to the privileges and immunities clause of article IV will be discussed in section II.H. A few theoretical questions of secondary importance - such as the status of unilaterally imposed reciprocity provisions, or the true ground of the old quarantine cases, or the significance of discrimination that is not in terms of state lines but rather in terms of city lines or multi-state regions - will be discussed only in connection with particular cases as they appear in Part III of this essay.

Part III contains a discussion of the Court's actual practice in the modern era. This discussion is limited to movement-of-goods cases, and it reveals that despite the Court's talk of balancing, the Court has been doing nothing more in this area than implementing the anti-protectionism principle. This is not a thesis that can be demonstrated just by looking at the results of the cases. I shall analyze the major opinions in some detail. We shall see that in some of the older opinions that are thought to exemplify balancing, such as Baldwin v. G.A.F. Seelig, Inc. ${ }^{48}$ and H.P. Hood \& Sons v. Du Mond, ${ }^{49}$ there is in fact no reference to balancing at all; the passages that are now quoted as balancing language are simply being taken out of context and misread. In

47. In particular, subsection II.A.3.

48. 294 U.S. 511 (1935).

49. 336 U.S. 525 (1949). 
some major recent opinions also, such as Exxon Corp. v. Maryland ${ }^{50}$ and Commonwealth Edison Co. v. Montana, ${ }^{51}$ there is no balancing language at all. Finally, even where balancing language does appear, as in Pike v. Bruce Church, Inc. ${ }^{52}$ or Hunt v. Washington State Apple Advertising Commission, ${ }^{53}$ it is but the thinnest veneer. The underlying concern with suppressing protectionism is perfectly visible to whoever will look. Despite all this, there is enough reference to balancing in the cases taken together so that it is worth explaining why balancing language appears, sometimes, if the Court never actually balances. I shall offer an explanation in section III.E.

The arguments of Parts II and III are mutually reinforcing. First, consider how the theoretical conclusions of Part II reinforce the argument of Part III. Interpretive claims are never (or very rarely) demonstrable conclusively. In the present context, the difficulty of distinguishing between a judicial practice of balancing (particularly protectionist effect balancing) and a judicial practice based on antiprotectionism is such that after the evidence of the cases and opinions is in, some readers will still regard it as uncertain what the Court is doing. But there is a Principle of Charity in Interpretation: other things being equal, we should interpret the behavior of a presumptively rational entity so that the behavior makes the best sense possible. ${ }^{54}$ What that means here is that if we are uncertain whether the Court is balancing or merely suppressing protectionism, and if what the Court should be doing is the latter, we have reason to conclude that what it is doing is the latter. Thus does Part II reinforce Part III.

As to how Part III reinforces Part II - Part II argues from constitutional first principles to establish that all the Court should do in movement-of-goods cases is suppress protectionism. But in a system of precedent, what the Court does can change what it should do. If the Court had been balancing in these cases for half a century, as is widely believed, then arguably the Court should continue to balance now whether or not first principles justified it in balancing when it began. However, since the Court has not been balancing, as I show in Part III, there is no reason for it to do so now.

50. 437 U.S. 117 (1978).

51. 453 U.S. 609 (1981). (I shall explain the use of a tax case.)

52. 397 U.S. 137 (1970).

53. 432 U.S. 333 (1977).

54. The phrase "Principle of Charity" is most closely associated with the philosopher Donald Davidson, but the basic idea is no one's invention and belongs to no one. My favorite embodiment of the idea is a motto confided to a friend of mine many decades ago by her Latin tutor. Apropos of my friend's attempts to construe a difficult bit of Vergil, the tutor observed: "If what you come up with doesn't make sense, it can't be right." 
In saying that the arguments of Parts II and III reinforce each other, I am not saying that the conclusions of the two Parts stand or fall together. The conclusion of either could be true and the other false. I am saying only that each Part tends to support the conclusion of the other. The argument of each Part should be evaluated in light of the evidence the other provides.

\section{Theory: What the Court Should Do}

\section{A. The Case Against Protectionism, and the Primacy of Purpose}

This section (II.A.) comprises three subsections. The first subsection sets out the basic case for judicial suppression of state protectionism. For purposes of making the basic case, protectionism is taken to be adequately represented by the classical instruments of protectionism - the tariff, the embargo, and the quota. The second subsection asks what feature or features of these classical protectionist instruments provides the crucial grounding for the case against protectionism, an inquiry that is necessary before we can decide what sorts of law other than the pure classical instruments should be regarded as protectionist. The conclusion of the second subsection is that protectionist purpose is the crucial feature. The third subsection then considers whether the definition of protectionist purpose put forward in the Introduction (I.B.) requires emendation in certain details, in view of the nature of the case against protectionism.

In a moment, I am going to ask the reader to imagine that she is drafting a constitution for the United States in the economic and social conditions of 1986. I shall not ask her to start from scratch. Since what we are interested in is the dormant commerce clause, we will ignore aspects of the constitution-writer's problem that do not bear on the issue of economic regulation; and we will run very rapidly through setting up the general federal framework that constitutes the background for the specific problem of what powers of economic regulation states should have. We will assume so much and go so fast in the beginning that the whole exercise of imagining that the reader is writing a constitution may seem empty. But I urge the reader to think in these terms in order to emphasize an important point about the nature of my argument. Let me explain.

My main thesis is that we should limit state powers to regulate the economy (specifically to regulate the movement of goods) by a prohibition on protectionist purpose rather than by any sort of balancing; 
and part of my case is a general objection to judicial balancing, just as part of most people's case for balancing is a general objection to judicial review of legislative purpose. But what I want to emphasize is that issues about judicial competence, or other issues about the appropriateness of certain sorts of judicial inquiry, are secondary.

The first question we should ask is how the drafter of the constitution would want to distribute governmental powers in an ideal scheme, if she could assume the existence of some magical enforcement device that would guarantee her scheme was perfectly followed. Of course, there is no magical enforcement device. Our main device for enforcing the constitution-writer's intentions is judicial review, which is far from magical. But before we worry about how the constitution-writer might adjust her scheme to take account of imperfections in the enforcement device, it surely makes sense to ask what her ideal scheme would be.

I claim the constitution-writer would formulate her ideal scheme for limiting state power to regulate the economy in terms of purpose. If courts are better at ascertaining purpose than at balancing (as I shall argue in section II.B. that they are), that merely reinforces a case for focusing on purpose that is independently grounded.

Notice, incidentally, that if the argument for suppressing state protectionism can be brought out in the exercise of imagining oneself a constitution-writer, it is necessarily a structural argument. I have no doubt the strongest argument for forbidding state protectionism is a structural argument. As I expound the structural argument I will make passing reference to the framers' intentions; and after the structural argument is complete I shall consider whether there is any textual basis for judicial review based on the dormant commerce clause.

Very well. Imagine you are writing a constitution for a federal union to be composed of fifty separate "sovereign" states. The states share a common primary language and a common background culture. On the other hand, the states vary greatly in their material circumstances and in their political and economic histories. As a result, the states often disagree significantly about those concrete value questions that are the stuff of ordinary legislative decisionmaking.

You have decided to establish a central legislature that will have broad powers, enabling it to deal with matters that touch on the general interests of the union or that the states for some reason cannot deal with effectively on their own. You have decided further that in the circumstances of 1986, this general description of the powers of the central legislature entails that the central legislature should have an essentially unlimited power to regulate economic activity (as well as 
much else, of course). Clearly, the central legislature (hereafter "Congress") must be supreme so long as it acts within its powers. To enforce this supremacy, and perhaps for other reasons as well, you have decided to institute a strong federal judiciary, which we shall refer to simply as "the Court."

It now occurs to you to wonder whether the constitution you are writing ought, in addition to creating a broad central power over economic activity, to limit the states' power in that area. This is of course the question of what content, if any, to give to the "dormant commerce clause." Many of the same considerations that argue for the essentially unlimited central power - in a nutshell, the complexity and pervasiveness of modern economic activity - argue strongly against treating the central power as exclusive. So, even though you are aware that much local economic regulation has nonlocal consequences, you have decided that there shall be no general prohibition on economic regulation by the states.

But perhaps there should be some specific prohibitions on economic regulation by the states. And so you ask yourself: Is there any sort of regulation the states might engage in that is sufficiently undesirable and also sufficiently amenable to judicial identification so that you want to direct the Court to watch out for and prevent such regulation without waiting for Congress to forbid it? ("Regulation" is here used in a broad sense, and includes taxing and spending programs.) Notice that if the Court is given any warrant to supervise state economic regulation when Congress is silent, then state courts will have such a warrant and duty as well, by virtue of the general principle elsewhere decided on that makes federal law supreme.

One bit of content for the dormant commerce clause occurs to you immediately. The Court should prevent states from engaging in protectionism directed against other states.

Now, what is protectionism, and why is it so obviously undesirable? The first question, about what protectionism is, does not require a detailed answer at this point. We all have an intuitive idea of the core behavior we think of as protectionist. It is the imposition of tariffs, embargoes, quotas, and the like, for the purpose of protecting local producers (farmers, manufacturers, laborers) against foreign competition. Even a tariff or an embargo justified by, say, an infant industry argument is not a core case, given that we normally think of protectionism by states as unequivocally bad. So, let us focus for the present on the true core cases, and let us consider why protectionism practiced by one state against others seems clearly unacceptable.

There are three objections to state protectionism, which I shall call 
the "concept-of-union" objection, the "resentment/retaliation" objection, and the "efficiency" objection.

The concept-of-union objection is so obvious that it is easily overlooked. State protectionism is unacceptable because it is inconsistent with the very idea of political union, even a limited federal union. Protectionist legislation is the economic equivalent of war. It is hostile in its essence.

In saying protectionist legislation is hostile, I do not mean that the harm to the foreign victims is necessarily valued for itself. The ultimate goal may be only promotion of local well-being. But the harm to foreign interests is also not merely incidental. The immediate intended means to improvement of local well-being is the transfer of certain profitable activities from foreign to local hands. Protectionism does not merely harm some foreign interests in the process of conferring an independent local benefit. Rather, it takes away from the foreigners in order to give to local residents exactly what has been taken away. Nations under arms are often no more hostilely disposed to their enemies than this. Such behavior has no place in a genuine political union of any kind.

Notice I have not said that all legislation that distinguishes between locals and foreigners is objectionable. A state does have a special relationship to its own citizens. Alaska may provide that only Alaskans can run for governor or share in the distribution of the state's oil royalties. Such legislation is not hostile to non-Alaskans in the way protectionism is hostile. It takes nothing away from nonAlaskans that we would normally think they have as much right to as Alaskans have.

The reader might wonder whether protectionist legislation is any more hostile than ordinary competitive economic behavior. When the Coca-Cola Company introduced its new flavor of Coke, it was trying to take business away from Pepsi-Cola and transfer that business to itself. We would not normally characterize Coca-Cola's behavior as hostile. We even tend to assume behavior like this is socially valuable.

Now, states do not ordinarily compete with each other for customers in the way Coca-Cola and Pepsi-Cola compete, but states do sometimes try to help local businesses compete by what we would think of as normal marketing techniques. Thus, the State of Michigan advertises Michigan as a vacation paradise for boaters and fishermen, hoping thereby to benefit the Michigan tourist industry, and recognizing that any benefit will come at least in part at the expense of other states' tourist industries.

Such behavior by Michigan is perfectly permissible. In my techni- 
cal scheme, Michigan's advertising fails to count as protectionist because of part (b) of the definition of protectionism. Advertising as a technique for seeking competitive advantage is not formally analogous to the tariff, the embargo, or the quota. The full explanation of part (b), and thus of why advertising and other standard competitive techniques do not seem as hostile as protectionism, must wait for section II.G. But for the present, developing our war analogy, we might say that protectionism takes over a market share by force; it is like acquiring territory by armed conquest. Advertising, like product improvement and other standard market ploys, uses no force; it encourages a free transfer of allegiance. It is like acquiring territory by plebiscite of the inhabitants.

The next objection to protectionism is the resentment/retaliation objection. If protectionism is conceptually inconsistent with political union, it is also practically inconsistent. Protectionist impositions cause resentment and invite protectionist retaliation. If protectionist legislation is permitted at all, it is likely to generate a cycle of escalating animosity and isolation (and even of hostility in the strongest sense, where the harm to foreign interests is valued as such), eventually imperiling the political viability of the union itself.

The people who wrote our actual Constitution in 1787 were well aware of this danger. They saw states enacting protectionist restrictions; they saw other states retaliating; and they feared not merely for the economic health, but also and even more for the political viability of the infant United States. ${ }^{55}$ Two centuries later, the prohibition on

55. The claims in the text that the framers saw protectionism and retaliation around them are part of the conventional wisdom about the origins of the commerce clause. Edmund Kitch has recently argued (following William Zornow, citations to whose work may be found in Kitch) that in fact there was almost no actual experience of protectionism and retaliation under the Articles of Confederation. Kitch, Regulation and the American Common Market, in RegulaTION, FEDERALISM, AND INTERSTATE COMMERCE, supra note 3, at 17-20. A superficial survey of the standard and easily accessible primary and secondary sources does nothing to undermine Kitch's claim. Surprising as it is, it may be true. For my purposes, however, it is more important what the framers feared (or what they thought they saw) than what they actually experienced. Kitch seems to concede that the framers (or at least the authors of The Federalist) feared interstate protectionism. Id. at 18 . That is enough for me, especially since my reliance on the framers' intentions is subsidiary to a structural argument based on our present understanding of federalism.

Since we have taken a peek behind the conventional wisdom, it may be worth mentioning another subtlety. Discussions of state protectionism tend to lump together three sorts of state behavior: (1) state impositions (tariffs, embargoes, and the like) on goods going to or from foreign nations; (2) state impositions (taxes, tolls) on transportation through their territories; and (3) state impositions (tariffs, and so on) on goods going to or from other states. These three behaviors are formally and functionally distinct, though they are also functionally interchangeable for some state purposes and in some contexts. There can be no doubt that the framers' primary concern was with the first sort of behavior (and its companion behavior, regulation of international shipping). THE FEDERALIST No. 22 (A. Hamilton). Equally, there can be no doubt the framers' next concern was with the second sort of behavior. Id. No. 42, at 267-68 (J. 
protectionism is so firmly entrenched in our constitutional jurisprudence that it is hard to be certain what might happen if it were suddenly abandoned. But one does not need to be especially cynical about the ways of politics to see a genuine danger that after state legislatures had waked up to the new possibilities open to them, and despite all that now binds the states together, the protectionist impulse would be strong enough to generate behavior that would seriously embitter our political life, making the prospects of wise government substantially less than they already are. 56

The third objection to protectionism is that it is inefficient. Now, "efficiency" is a treacherous notion. Let us pause to be sure we know what we are saying. Why exactly is protectionism inefficient? The obvious answer is that tariffs, embargoes, quotas, and the like interfere with efficiency in the production of goods; they divert business from low-cost (foreign) to high-cost (local) producers.

For some purposes, the statement that protectionism is inefficient because it diverts business from low-cost (foreign) to high-cost (local) producers would be perfectly adequate. But for our purposes, it is inadequate. It tells part of the story, but not the whole story, of why

Madison) (C. Rossiter ed. 1961). There is extremely little direct evidence of specific concern with the third sort of behavior. Some evidence may be found, however, in THE FEDERALIST Nos. 6, 7 (A. Hamilton) (note the general analogy of unfederated states to independent nations) and also in No. 11 (A. Hamilton) (note the concern for the advantages of circulation among the states of the products of the states). Also, see 2 THE RECORDS OF THE FEDERAL CONVENTION OF 1787, at 441 (M. Farrand rev. ed. 1937) for a specific reference by Madison to the third sort of behavior during the Convention, and, for references to instances of the behavior, 3 id. at 548; C. WARREN, The MAKING OF THE CONSTITUTION 567-68 \& n.1 (1937). In sum, though the evidence is not what one would like, I think there is sufficient evidence of concern on the part of the framers with state behavior of the third sort (which is my principal concern here in section II.A. and throughout this essay except when I discuss transportation in section II.F.) so that I am willing to rely on the conventional claims about the framers' intentions insofar as I am concerned with constitutional origins at all.

Incidentally, as to the claim in the text that the framers were worried about commercial rivalry as a threat to the political viability of the new union, see THE FEDERALIST Nos. 6, 7 (A. Hamilton).

56. Kitch, supra note 55, disagrees with this proposition as well. "Free trade among decentralized authorities will result from voluntary cooperation, motivated by the fact that free trade will produce greater wealth for all to share." Id. at 13-14. Indeed, Kitch's primary interest in the experience under the Articles of Confederation is not for the light it throws on the framers' intentions, but rather for its force as an example for the proposition that decentralized authorities will achieve free trade. Id. at 19. Kitch's claim seems to me utopian Coaseism. Whatever may have been the experience of the Confederation, the state of modern international trade suggests that while decentralized authorities will have some incentive to achieve free trade and will make some attempts, they will be only partially successful. If the experience of the Confederation is to the contrary, that may be partly because interstate trade was relatively undeveloped, for technological reasons.

Incidentally, part of the difficulty in achieving free trade is that Kitch's decentralized authorities are not monoliths negotiating simply with each other; rather they are entities with internal politics and with factions favoring and opposing free trade (product by product) within each entity. 
classical protectionist measures seem so self-evidently objectionable on efficiency-related grounds.

The first problem with the statement as it stands is this: It suggests that every law which diverts business away from the producers who currently have it is necessarily diverting business from low-cost to high-cost producers and impairing efficiency. But that need not be so.

Consider the Oregon bottle law. ${ }^{57}$ That law diverted business from can manufacturers to bottle manufacturers and, because of the increased transportation cost associated with heavier containers, from out-of-state bottlers to in-state bottlers. But there is no reason to think the Oregon bottle law impaired productive efficiency. The object of the law was to discourage a mode of production, the packaging of beverages in nonreusable and nonreturnable cans, that created costs (in the form of litter) not accounted for by market mechanisms. In other words, the object of the law was to improve productive efficiency by correcting an inefficiency that resulted from an external cost of the existing productive process.

Oregon attempted to correct the inefficiency partly by requiring internalization (the provisions about mandatory refunds for returned containers) and partly by prohibiting outright certain specially obnoxious modes of production (packaging in pull-top cans). Oregon's methods may not have been theoretically ideal; but they were perfectly reasonable. States are not required to legislate only in ways that would be approved by a committee of theoretical welfare economists. In sum, even though the Oregon bottle law diverted some business from (foreign) producers who currently had it to other (local) producers, there is no reason to condemn the law as inefficient.

We can make the same point about the Oregon bottle law in the language of "low-cost" and "high-cost." Our belief in the general responsiveness of market behavior gives us reason to assume that packaging beer in lightweight nonreturnable metal cans outside Oregon (for the most part) and shipping it into Oregon is the low-cost method of distributing beer in Oregon if costs are evaluated by the scheme implicit in the legal status quo prevailing before the bottle law. But that scheme takes no account of the cost of litter. Oregon decided that the cost of litter was significant and should be assigned to the modes of production that caused it. The same belief in the responsiveness of markets that leads us to assume that filling metal cans outside Oregon was the low-cost mode of packaging under the old cost-assignment scheme should equally lead us to assume that filling glass bottles

57. Discussed in section I.D. supra. 
within Oregon (to a greater extent than before) is the low-cost mode of packaging under the new cost-assignment scheme. So, just as the Oregon law diverts business from low-cost producers to high-cost producers under the old scheme, it diverts business from high-cost producers to low-cost producers, a clear gain, under the new scheme. Neither scheme has any preferred status from the point of view of constitutional law or economic theory. There is therefore no warrant at all for criticizing the Oregon law on the ground that it diverts business from low-cost producers to high-cost producers.

Our discussion of the Oregon bottle law makes it clear that we cannot be satisfied with a statement of the efficiency objection to protectionism that suggests that every law that diverts business away from (foreign) producers who currently have it impairs productive efficiency and thus shares the evil of protectionism. How shall we reformulate the efficiency objection in order to avoid this suggestion?

We could say that protectionism is inefficient because it diverts business from producers who are the low-cost producers under the cost-assignment scheme implicit in the legal status quo, without the state's even claiming the justification, which Oregon claimed for its bottle law, that that cost-assignment scheme is defective. Or, compressing what we have just said: protectionism is inefficient because it diverts business away from presumptively low-cost producers without any colorable cost-based justification.

This reformulation of the efficiency objection is an improvement, but it is still not fully acceptable. The change we have made, focusing as it does on cost-based justification, responds too exclusively to the Oregon bottle law. We can see the need for further reformulation by considering a somewhat different case, Exxon Corp. v. Maryland. ${ }^{58}$ If we give the Maryland legislature the benefit of any doubts about its purpose, the object of the Maryland law forbidding ownership of retail service stations by producers or refiners of petroleum was to secure fairer treatment of independent service station operators. Is that a "cost-based justification" for the diversion of retail business away from vertically integrated oil refiners? There may be room for someone to argue that this fairness justification for the Maryland law is not costbased; but if there is room, that merely shows that a formulation of the efficiency objection in terms of cost-based justification is still not the right formulation. Whether or not we regard the claimed justification for the Maryland law as cost-based, the justification prevents the law from being self-evidently and unambiguously objectionable in the way

58. 437 U.S. 117 (1978). 
a classical tariff is. (Remember we are assuming innocent purpose.) To be certain we exclude the Maryland law from the scope of the efficiency objection, we need to state the efficiency objection to protectionism more narrowly still, if we can find a way to do so.

Here is the proper formulation: protectionism is inefficient because it diverts business away from presumptively low-cost producers without any colorable justification in terms of a benefit that deserves approval from the point of view of the nation as a whole. Or, again compressing slightly: protectionism is inefficient because it diverts business away from presumptively low-cost producers without any colorable justification in terms of a "federally cognizable benefit."

Consider once more the classical tariff, and see how this reformulated efficiency objection fits it. The classical protectionist tariff diverts business away from those producers who currently have it, and the only benefit sought by the state imposing the tariff is a transfer of welfare from foreign producers (firms or workers) to their local counterparts. This transfer is a benefit from the narrowly self-interested viewpoint of the state imposing the tariff; but by its very nature this benefit to the imposing state is balanced by an equal loss to some other state or states. From the point of view of the nation as a whole, such a bare transfer of welfare between similarly situated parties in different states creates no benefit at all.

It is clear, then, that a classical tariff aims at no federally cognizable benefit, no benefit that deserves approval from the point of view of the nation as a whole. But what about the Oregon bottle law, or the Maryland law about service stations? Must there be a national policy in favor of reducing the litter in Oregon's parks and highways, or must we be able to say there should be such a national policy, before we can say the Oregon law seeks a federally cognizable benefit? No. The states are independent entities. Part of the point of federalism is to allow states to make their own decisions about such matters as what sort of an environment they value and want to maintain. So long as there is no constitutionally stipulated policy against minimizing litter (that is, no constitutionally stipulated policy in favor of litter as such), the elimination of litter from Oregon's parks and highways is a good thing from the federal viewpoint if Oregon says it is. Similarly, so long as there is no constitutional policy against fairer treatment (or what Maryland views as fairer treatment) for independent service stations, securing fairer treatment for independent service stations in Maryland is a good thing from the federal viewpoint if Maryland says it is.

I say that in the absence of a contrary constitutional policy, litter reduction in Oregon (for example) is a good thing from the federal 
viewpoint if Oregon says it is. I mean, of course, that it is a good thing from the federal viewpoint for purposes of constitutional law issues if Oregon says it is. There may be a national policy in favor of litter that is not constitutionally stipulated but that emanates from Congress. In that case, the Oregon law may be invalid, but its invalidity is a matter of statutory preemption. And even then, the invalidity is not strictly a matter of Oregon's pursuing an inadmissible policy. It is a matter of Oregon's attempting to enforce a law whose effects are inconsistent with a congressional policy. Notice also that in saying litter reduction in Oregon is a good thing for constitutional law purposes if Oregon says it is, I am not saying Oregon may seek to reduce litter by violating independent constitutional rights or by legislating in terms of forbidden classifications. Those limitations are effective even when the state is pursuing genuine values.

So, the Oregon bottle law and the Maryland service station law seek federally cognizable benefits; the classical tariff, embargo, and quota do not. So far so good for our latest formulation of the efficiency objection, according to which protectionism is inefficient because it diverts business away from presumptively low-cost producers without any colorable justification in terms of a federally cognizable benefit.

There is one last sort of law on which we ought to test this formulation of the efficiency objection. Up to this point, when we have talked about tariffs we have had in mind classical protectionist tariffs - tariffs passed for the protectionist purpose of aiding local producers in their competition with foreign producers. But imagine now a tariff which the legislature claims is passed, not for protectionist reasons, but solely to raise revenue. This hypothetical revenue-tariff may seem to create a problem for our formulation of the efficiency objection. On the one hand, we have no doubt that this revenue-tariff must be unconstitutional; and we must be able to brand it unconstitutional without any investigation into the relative importance in the legislature's motivational scheme of the claimed revenue purpose and the anti-competitive purpose which is almost certainly also present to some degree. On the other hand, it seems that raising revenue for the state treasury is a federally cognizable benefit. So how can we say without a searching investigation into the legislature's motives that the revenue-tariff is inefficient, if that requires that it have no colorable justification in terms of a federally cognizable benefit?

First off, let there be no doubt that raising revenue for the state treasury is, in my view, a federally cognizable benefit. A private-topublic transfer of resources must be regarded as a benefit from the 
federal point of view if the state says it is. (Again, that does not mean there are no limits on how this benefit may be sought.)

But even though raising revenue for the state treasury is a federally cognizable benefit, this benefit does not justify the revenue-tariff. What makes the revenue-tariff a tariff and not a general tax is its discriminatory aspect, its taxing the products only of foreign producers. This discriminatory aspect of the tariff not only does not promote the revenue purpose, it wars against it. The failure to tax local products decreases revenue. Furthermore, it is only by virtue of this discriminatory aspect that the tariff diverts business from foreign producers to local. So, the feature of the tariff that common sense recognizes as the essence of its tariff-ness, and which causes the diversion of business, makes no contribution to raising revenue. The point of the feature is rather to assure that what revenue is raised is raised at foreign expense. This purpose, to raise revenue for the state at the expense of foreigners specifically, is not a federally cognizable benefit. ${ }^{59}$

In sum, the discriminatory aspect of the revenue-tariff, which is the aspect that makes it a tariff and not a general tax, is objectionable under our formulation of the efficiency objection to protectionism. The discriminatory aspect of the tariff causes a diversion of business away from presumptively low-cost foreign producers, without any colorable justification in terms of a federally cognizable benefit. For this reason and other reasons indicated by our other objections to protectionism, the discriminatory aspect of the tariff is unconstitutional. (Whether the court should cure the unconstitutionality by striking down the tariff as a whole or by merely eliminating the discrimination and turning the tariff into a general tax is a question to be decided by ordinary principles about severability.)

The reader may wonder whether my analysis of the revenue-tariff has any relevance to actual problems or whether it is merely a logical complication created by my own theory. The answer is that it has definite relevance to actual problems. To be sure, no state legislature would think of passing a tariff and defending its constitutionality on the ground that it raised revenue. But the State of New Jersey did something exactly analogous when it passed the statute forbidding the

59. Will someone object that the revenue is not raised at foreign expense because the tariff is paid by local actors such as importers and ultimately paid by the local consumer? This overlooks the fact that in the final analysis the burden is almost certainly shared by all parties, including producers. And the point of the discriminatory aspect of the tariff is to see that insofar as the burden of the tariff is borne by producers, it is borne by foreign producers and not by local. The only way to de-emphasize this purpose to externalize a part of the revenue burden is to deemphasize the revenue aspect of the tariff entirely. But then the point of the tariff must be to shift business from foreign producers to local. In short, we are looking once again at a classical protectionist tariff. 
import of foreign waste that was invalidated in City of Philadelphia $v$. New Jersey. ${ }^{60}$ New Jersey defended that statute on the ground that it was designed to conserve scarce landfill space, which is certainly a federally cognizable benefit. The objection to the law was that the burden of conservation was thrown entirely on foreigners, who were singled out just because they were foreigners. Conserving privately owned landfill space for local use by denying access only to foreign users is precisely like raising revenue for the state treasury by taxing only foreign producers. Just as the discriminatory aspect of the revenue-tariff is both the source of the diversion of business and inimical to revenue-production (inasmuch as local products are exempted from the tariff), so also the discrimination between local and foreign garbage sources was both the source of the diversion of landfill space from foreign to local users and inimical to conservation (inasmuch as locals were allowed totally unrestricted access). The Court correctly held that the discrimination could not be justified by pointing to the conservation purpose. 61

There is one more issue I want to raise about the revenue-tariff: Does the revenue-tariff count as being motivated by protectionist purpose, under the definition of protectionist purpose in section I.B.? Obviously this issue takes us beyond the question about the formulation of the efficiency objection that made us notice the revenue-tariff. But discussing this new issue now will save us bringing up the revenuetariff again later.

We have seen that the revenue-tariff in its discriminatory aspect is subject to the efficiency objection to protectionism. That is, it diverts business without aiming at any federally cognizable benefit. But someone might still suggest that the revenue-tariff is not motivated by protectionist purpose as I have defined protectionist purpose. Specifically, someone might suggest that even though the revenue-tariff does in fact improve the competitive position of local producers, and with no colorable justification, still the revenue-tariff does not have the specific purpose of improving the locals' competitive position.

I want to resist this suggestion. For reasons of theoretical econ-

60. 437 U.S. 617 (1978).

61. For a fuller discussion of Philadelphia v. New Jersey, see section III.D. infra. Incidentally, New Jersey's landfill statute was different from the revenue-tariff in one respect. The revenue-tariff discriminates between local and foreign producers, while the New Jersey landfill law discriminated between local and foreign consumers. Whether "consumer protectionism" ought to be covered by the anti-protectionism principle is a topic reserved for discussion in subsection II.A.3. infra. I shall conclude, as the Court has concluded, that consumer protectionism should be covered. With that understanding, the New Jersey landfill law and the revenue-tariff are precisely analogous. 
omy (and, to a lesser extent, for reasons of expository convenience), I want it to be the case that the revenue-tariff and analogous laws like the New Jersey landfill law can be condemned under the purposebased anti-protectionism principle as I have already stated it.

One way to resist the suggestion that the revenue-tariff is not motivated by specifically protectionist purpose is to argue that any actual revenue-tariff or analogous law almost certainly would be sufficiently motivated by protectionist purpose as I have defined it to come under the anti-protectionism principle. When $I$ address the question of multiple legislative purposes (in section II.B.), I shall argue that a law should be struck down if a protectionist purpose "contributed substantially" to its adoption. As a practical matter, it seems very unlikely that even a self-proclaimed revenue-tariff would ever be so purely motivated by revenue considerations that the legislators' perception of the obvious and immediate competitive advantage to local producers would not have "contributed substantially" to the statute's adoption. But I am prepared to save us worrying about this practicality by stipulating, just in case there would otherwise be any doubt, that the revenue-tariff (or more specifically, the discriminatory aspect thereof) counts as having protectionist purpose. This stipulation is justified by the following considerations: (1) It seems inconceivable that the legislature adopting the revenue-tariff, which legislature is by hypothesis engaged in one sort of purposeful discrimination in favor of local producers and against foreign (that is, with regard to who shall bear the burden of the revenue-raising program), would not also be motivated to some degree by the prospect of the competitive gain for local producers. (2) If the legislature had some other permissible purpose, we might not want its ability to pursue that purpose to be frustrated by a minor taint of protectionist purpose; but we have seen that in the case of the revenue-tariff, the discriminatory aspect is not justified by any permissible purpose. Since there is bound to be some taint of protectionist purpose and there is no permissible purpose, it seems reasonable to say that the whole purpose of the discriminatory aspect of the tariff is protectionist.

The same considerations that support my stipulation that the revenue-tariff counts as having protectionist purpose also support a further stipulation, which I now make, that any law analogous to the revenuetariff, such as the New Jersey landfill law in Philadelphia v. New Jersey, counts as having protectionist purpose. This stipulation is almost certainly not necessary to justify us in claiming that there was protectionist purpose in Philadelphia v. New Jersey. It is even harder to imagine legislators distinguishing between the (not specifically pro- 
tectionist) purpose to protect local consumers' access to landfill and the (specifically protectionist) purpose to give local landfill consumers a competitive advantage over foreign consumers than it is to imagine legislators distinguishing between the (not specifically protectionist) purpose to spare local producers from a tax and the (specifically protectionist) purpose to increase local producers' share of the market. And I suspect that most real-world cases are more like Philadelphia v. New Jersey in this respect than like the revenue-tariff. But in any event, the stipulation applies to all cases which are analogous to the revenue-tariff in the respects we have discussed. (Notice that although both the revenue-tariff and the New Jersey landfill law discriminate explicitly by state lines, explicitness is not an essential feature from the point of view of our present discussion.)

By a mixture of argument and stipulation, we have now settled the issue whether the revenue-tariff and analogous laws count as having protectionist purpose. They do (in their discriminatory aspect).

Throughout the discussion of the revenue-tariff and analogous laws we have also been arguing in effect for the following important claim, which I hope will now seem obvious: To the extent that our efforts to suppress protectionism should focus on legislative purpose (and I shall argue in subsection II.A.2. that purpose is precisely what our efforts should focus on), a law is unconstitutional if any feature of the law (like the discriminatory aspect of the revenue-tariff) is motivated by protectionist purpose.

Note that the "any feature" issue is not the same as the multiple purpose issue which I shall discuss in section II.B. The multiple purpose issue can arise in connection with a law which is formally perfectly unitary, that is, which does not present any distinct or potentially severable "features." And similarly, a distinguishable feature of a law may have a perfectly unitary purpose. Of course, a distinguishable feature may also seem to reflect in itself multiple legislative purposes, in which case the analysis of the multiple purpose issue discussed in section II.B. must be applied to the individual feature in order to decide whether that feature should be treated as motivated by protectionist purpose. But all I am now saying is this: Once we have decided that any particular feature of a law counts as being motivated by protectionist purpose, then the law cannot stand with that feature intact. Either the law as a whole must be struck down, or the objectionable feature must be excised. ${ }^{62}$

Returning now to our point of departure for the revenue-tariff dis-

62. What I say in the text does not apply without qualification to cases involving the state as market participant (or more generally, to laws which are exempted by part (b) of my definition of 
cussion, we have seen that the efficiency objection to protectionism comes to this: protectionism is inefficient because it diverts business away from presumptively low-cost producers without any colorable justification in terms of a federally cognizable benefit.

I have put the efficiency objection last, even though it would occur first to many constitutional scholars, because it deserves to be downplayed. The relevant sense of "efficiency" turns out to be much weaker than one might at first assume; and the objection also was not primary in the framers' thinking. The people who wrote our Constitution were by no means thoroughgoing free traders. They envisaged a mercantilist foreign trade policy for the United States as a whole. One reason they wanted to locate the power to regulate commerce with foreign nations in Congress was that independent regulation of such commerce by the states prevented the implementation of an optimal national mercantilist policy. ${ }^{63}$ The framers did have some efficiencyrelated objection to interstate protectionism. They argued that eliminating preferential state regulation of trade would encourage agriculture and industry. ${ }^{64}$ But that is a much narrower claim than is suggested by modern apostles of efficiency, who operate with a strong presumption in favor of total economic laissez-faire. The framers would have recognized many good reasons for state economic regulation, and they would have recognized that the states must be the primary judges of what are good reasons. To the extent the framers were concerned with efficiency, it seems reasonable to think of their objection as being the objection I have formulated.

The structural argument against state protectionism is now complete. It remains only to consider whether there is a textual argument as well. In my opinion, the structural argument does not need to be supported by an argument from any single short bit of text (which is what lawyers normally mean by a "textual" argument), so long as there is no short bit of text that contradicts the structural argument (and there is none). Even so, let us see what we make of the text in bits.

Does the constitutional text include any bit that prohibits state protectionism? That depends, not surprisingly, on how the bits are approached. If we ask whether there is any bit of text that, taken by itself, naturally suggests to a modern reader that the states are forbidden to engage in protectionism against other states, the answer is easy:

protectionism). The special circumstances under which protectionist purpose may be permitted are discussed in section II.G. infra.

63. See The Federalist Nos. 11, 22 (A. Hamilton).

64. The Federalist No. 12 (A. Hamilton). 
No, there is not. But there is another question, still about bits of text, that may be of interest. Is there any bit of text that might have suggested to a reader in 1787 that state protectionism was forbidden? Or, what is almost the same question, is there any bit of text that we could reasonably take to embody a final intention of the framers to forbid state protectionism, if we have independent reason to think the framers intended to forbid it and intended the text to say so? Here, the answer is: Yes. The relevant bit of text is the words, "The Congress shall have power ... to regulate commerce . . . among the several states ....".65

There is much evidence that the main point of this grant (unlike the grant of power over foreign commerce) was not to empower Congress, but rather to disable the states from regulating commerce among themselves. ${ }^{66}$ The type of commercial regulation uppermost in the framers' minds was what we might categorize generally as mercantile regulation - regulation of navigation, customs regulation, and the like. ${ }^{67}$ The framers wanted commerce among the states to be free of state-originated mercantilist impositions. Giving Congress the power to regulate internal commerce was one way of denying states that power, under the view, much more natural to the framers than to us, that granted regulatory powers were exclusive. I have remarked previously that as Congress' power over interstate commerce is now understood, we cannot treat that power as exclusive. But that does not mean the framers could not have regarded as exclusive the much narrower power they were thinking of. There is considerable evidence that they did so regard it. 68

It is time now to consider what should count as protectionism. We have made the case against protectionism without benefit of a precise definition of the phenomenon, by taking the classical core cases of protectionist legislation as representative of the whole category. We now

65. U.S. CoNST. art. I, $\S 8$, cl. 3.

66. See Abel, The Commerce Clause in the Constitutional Convention and in Contemporary Comment, 25 MinN. L. REV. 432, $481-94$ (1941).

67. Id. at 442-64.

68. Id. at 481-94. Of course, if the commerce clause forbids state mercantilist legislation, then it also provides a ground for judicial review to prevent such legislation. But notice that this argument for judicial review extends only so far as state legislation is flatly prohibited, which is to say, only so far as Congress' power is exclusive. This argument provides no ground for judicial review of all state legislation which is "commercial" in the sense that it duplicates what Congress might do under its (largely nonexclusive) commerce power as presently interpreted. (It is a very natural extension of the mercantilist exclusion, however, to say the Court may suppress what is superficially ordinary commercial legislation if that legislation has a protectionist purpose.) 
want to know what sorts of law other than the classical tariff, embargo, and quota fall under the same condemnation.

The classical tariff or embargo or quota joins three features: (1) It is explicit; that is, it legislates expressly in terms of state lines. (2) It is motivated by protectionist purpose; its object is to improve the competitive position of local economic actors, just because they are local, visà-vis their foreign competitors. (3) It produces a protectionist effect; it diverts some business from foreign economic actors to their local competitors.

Can we identify one of these three features of classical protectionist measures as central? Yes, we can. If we consider in turn our three objections to protectionism - the concept-of-union objection, the resentment/retaliation objection, and the efficiency objection - we shall see that in connection with each of these objections the centrally relevant feature of classical protectionist legislation is protectionist purpose.

Note that for the present I am still interested in the constitutionwriter's ideal scheme. I want to consider the three features of classical protectionism (explicitness, purpose, effect) in light of the three objections to protectionism without worrying either about judicial competence to ascertain whether any particular (nonclassical) law has the features or about other possible drawbacks to particular judicial inquiries. Clearly, it will be easier for a court to identify laws that speak explicitly in terms of state lines or laws that have some protectionist effect than to identify laws enacted with protectionist purpose. I shall discuss the significance of that fact in due course. But for now, $I$ just want to ask which feature of the core instances of protectionism makes them so obviously bad.

Let us consider first the concept-of-union objection. If we ask which feature makes protectionist legislation antithetical to the very idea of federal union, the answer is obvious. It is the protectionist purpose, the unvarnished intention of taking something away from other states just to enjoy it at home. ${ }^{69}$

As to explicitness and the concept-of-union objection - states legislate in terms of state lines for many perfectly acceptable reasons. I

69. It is true that in one special class of cases, Hughes v. Alexandria Scrap Corp., 426 U.S. 794 (1976), and its progeny, the Court does not seem to regard protectionist purpose as inconsistent with the concept of union. As I have said already, I will discuss this exception to the ban on protectionist purpose in section II.G. Put very crudely, the point about these cases is that they do not involve the state taking away anything from out-of-staters. (That claim requires development; it will receive it in due course.) For the present, we are concerned with the question of what aspect of classical protectionism is crucial for grounding the objections to it. We can deal adequately with that issue while ignoring the Alexandria Scrap exception. 
have noted previously that only Alaskans may be Governor of Alaska, and only Alaskans may share in the distribution of Alaska's oil royalties. Even a law regulating private behavior that is indistinguishable on its face from an embargo might be not merely consistent with union but actually motivated by interstate comity. Imagine that Illinois has a drinking age of twenty-one and Wisconsin, which borders on Illinois, has a drinking age of eighteen. Illinois eighteen-to-twenty-yearolds flock to Wisconsin to drink. Out of deference to Illinois' policy regarding Illinois residents, Wisconsin passes a law forbidding the sale of alcohol in Wisconsin to Illinois residents (but not Wisconsin residents) under twenty-one. There is now an explicit discrimination in Wisconsin law between nineteen-year-olds from Wisconsin and nineteen-year-olds from Illinois. The law has the form of an embargo; the same law might even be passed as an embargo if there were a shortage of beer halls in Wisconsin serving the eighteen-to-twentyyear-old population and this resource were being conserved for Wisconsinites. But the law as I have imagined it involves no protectionist purpose. It involves rather the most sensitive concern on the part of Wisconsin for its neighbor's policy. This is just what a federal union needs. (I am sure some readers will think my Wisconsin statute violates the equal protection clause or the privileges and immunities clause of article IV. I think it does not. But it is enough for now to say the statute quite obviously does not contradict the very idea of federal union as protectionism does.)

Protectionist effect, considered in itself, is also perfectly consistent with the concept of union. Remember the Oregon bottle law. If we believe, as the Oregon appellate court held, that the statute was passed not from any protectionist impulse but from a genuine concern with the Oregon environment, then the legislation is fully consistent with the idea of union. Oregon cannot be forbidden to follow a sensible and innocent policy for its internal regulation just because implementing the policy causes some harm in neighboring states, nor even because the harm takes the form of diversion of business from foreign bottlers to Oregon bottlers. There is nothing in the idea of federal union that suggests Oregon's laws must be as favorable as possible to foreign bottlers in their overall effect; and there is nothing that makes sacrosanct that particular level of success in the Oregon market that foreign bottlers enjoyed just before Oregon decided nonreturnable containers were an environmental nuisance. Therefore there is nothing in the idea of union that prevents Oregon from enacting a law that diminishes foreign bottlers' success in the Oregon market, provided the law 
does not have the diminution of foreigners' success in the market as its object.

Someone might urge that even if protectionist effect is not absolutely inconsistent with the concept of union, still the concept of union requires that protectionist effect at least be regarded as (in itself) a constitutional disvalue. The argument for this claim goes as follows. Federal union implies economic union and a common market. It implies that any producer, anywhere in the country, should have access to all the country's markets when he comes to selling his product. But the Oregon bottle law denies certain foreign container manufacturers and bottlers access to the Oregon market. If union requires access and the Oregon law denies it, then surely that denial must at least count against the constitutional validity of the Oregon law.

This argument rests on a misunderstanding. When we say every producer ought to have access to all the country's markets, what we mean is just that he should not be shut out of any market by preferential trade regulations directed against him as a foreigner. ${ }^{70} \mathrm{We}$ do not mean that he has a right to deal with would-be customers in any state in disregard of that state's general legislation about what products are appropriate for sale there. When Oregon passed its bottle law, it decided that certain containers (pull-top cans) and certain modes of beverage distribution (sale in nonreturnable containers) were not wanted in Oregon. On such a matter, it is the state's prerogative to speak for all its citizens. (This is what is entailed by the concept of a federal union.) No citizen of Oregon has a right to ignore Oregon's decision; and no foreign producer has a right to deal with citizens of Oregon who are dissatisfied with their state's decision. The foreign producer of pull-top cans and the foreign bottler in nonreturnable containers have no constitutional interest at all in being able to sell in Oregon in defiance of Oregon's ban. If the bottle law incidentally diverts some business to local producers, that is a matter of no constitutional significance. ${ }^{71}$

In sum, it is protectionist purpose that grounds the concept-ofunion objection to protectionism.

Let us turn now to the efficiency objection to protectionism and

70. The idea that access to markets is a central value received its most famous expression in Justice Jackson's opinion in H.P. Hood \& Sons v. Du Mond, 336 U.S. 525, 539 (1949). But Jackson meant no more by his talk of access than what I suggest we should mean in the text. See the extended discussion of Jackson's opinion in section III.C. infra.

71. For related discussion, see section II.E. infra, especially the passage on the supposed value of the "free movement of goods." And if the reader wonders why Oregon may speak for its citizens in rejecting certain kinds of beer cans but not in rejecting foreign-bottled beer as such, she should see note 163 infra. 
consider what feature of classical protectionism gives rise to this objection. (We shall come back to the resentment/retaliation objection presently.) Remember that a law is inefficient in the relevant sense if it diverts business from presumptively low-cost producers without any colorable justification in terms of a benefit that deserves approval from the point of view of the nation as a whole (what $I$ have referred to as a federally cognizable benefit).

A law which is an explicit embargo in form may aim at an undoubted national benefit. Imagine that the State of Wyoming is home to an animal called the wuzzie, which has something in common with the Japanese blowfish. The meat of the wuzzie is a great delicacy, known until recently only to connoisseurs in Wyoming. But the meat of the wuzzie is fatally poisonous unless it is properly cured by a complex and delicate process. There are a small number of competent wuzzie curers in Wyoming and none elsewhere. The fame of wuzzie meat is beginning to spread; people in other states want to try it. Some wuzzies have been shipped out-of-state, where the meat has been improperly cured, resulting in two deaths. Wyoming now passes a law forbidding the export of wuzzies or uncured wuzzie meat. The export of cured wuzzie meat is allowed. Wyoming is not trying to keep the wuzzie meat, nor even the wuzzie curing business, for itself; it is only trying to see that wuzzie meat is cured by competent curers, all of whom happen to be in Wyoming. In form, this is an explicit embargo. (And it is no less an embargo for allowing the export of wuzzie meat after curing.) But there is no doubt the law, with the purpose I have specified, aims at a national good. And if we think only about the short run, it is probably the best way to pursue that good, being simpler administratively than the obvious alternatives. So, this explicit embargo has a colorable justification in terms of a federally cognizable benefit and escapes the efficiency objection. ${ }^{72}$

As to protectionist effect, we already know that protectionist effect by itself does not trigger the efficiency objection. Remember our discussion of the proper formulation of the objection. The precise basis of dissatisfaction with our first, crude formulation was that it seemed to condemn all laws with protectionist effect, including laws like the

72. Will someone object that Wyoming has no business trying to protect out-of-state consumers of wuzzie meat against the incompetence of out-of-state curers (and therefore that this is not a federally cognizable benefit when Wyoming seeks it)? The objection is frivolous. Surely Wyoming could flatly forbid all home consumption or export of wuzzies or their meat on the ground that even after the most expert curing the residual danger is too high. No out-of-stater and no other state which thought differently from Wyoming could assert a constitutional right of access to Wyoming wuzzie meat. But Wyoming would have no ground for the no-export aspect of this scheme except its desire not to contribute to harm occurring elsewhere. So we must admit that this is a perfectly good ground. 
Oregon bottle law which produced some protectionist effect incidentally to the pursuit of federally cognizable benefits. The whole point of reformulating the objection was to guarantee that certain laws with protectionist effect escaped it.

If neither explicitness nor protectionist effect is what is important for the efficiency objection, we can conclude that once again the crucial feature is protectionist purpose. Consider. If a law which diverts business from foreign producers to local producers is motivated by protectionist purpose, it aims only at transferring welfare from foreigners to their local counterparts. That is not a federally cognizable benefit. ${ }^{73}$ On the other hand, if the law is not motivated by protectionist purpose, it must have some other purpose. That other purpose, whatever it is, will provide a colorable justification in terms of a federally cognizable benefit, since anything else the state aims at by way of economic regulation must be counted a benefit from the national point of view for constitutional law purposes. (What I say here is of course limited by the dormant commerce clause context. A state law that aims at suppressing political speech by Democrats, or at demeaning racial minorities, or whatever, aims at no federally cognizable benefit. But these limitations do not stem from the commerce clause. Those objects would be federally cognizable benefits if the dormant commerce clause were the only clause of the Constitution that restricted state legislation.) In sum, it is protectionist purpose that is crucial for the efficiency objection.

The reader might suggest that protectionist effect, even if it is not a sufficient condition for inefficiency in our sense (as we have seen), is still a necessary condition, since a law without protectionist effect does not divert any business. This is true, but it is a quibble. It is most unlikely that a law passed with protectionist purpose would have no protectionist effect. It is equally unlikely, for logically related reasons, that a court that found no protectionist effect from a law would believe the law was passed for a protectionist purpose. In any event, a law with protectionist purpose, even if it has no protectionist effect, is inconsistent with the concept of union and invites retaliation (if resentment is not overwhelmed by contempt for the would-be protectionist legislature's incompetence). A law with protectionist purpose deserves condemnation regardless of effect.

73. In the text I implicitly assume pure protectionist motivation; the possibility of multiple purposes is discussed in section II.B. infra. I also implicitly exclude the state-as-market-participant cases, in which, because the state is spending its own resources, pure protectionist purpose does not imply a mere attempt to transfer welfare from foreigners to locals. For full discussion of these cases, see section II.G. infra. 
The reader might make a different suggestion which is not a quibble. Remember that a law is subject to the efficiency objection if it diverts business from presumptively low-cost producers without any colorable justification in terms of a federally cognizable benefit. Now, if we limit ourselves to asking which of explicitness, protectionist purpose, and protectionist effect is the crucial variable for the efficiency objection, the correct answer is protectionist purpose, as we have seen. But, the reader might say, why not look at another variable, specifically, at the achievement vel non of some actual good effect by the law under consideration. Why limit ourselves to inquiring whether there is a colorable justification for the diversion of business (a formulation that directs us to a purpose inquiry); why not look for an actual justification?

This suggestion can be interpreted in more than one way. If the suggestion is that the court should identify and quantify and evaluate the good effects of the statute to see whether they actually justify the cost of the statute in diversion of business, then what is suggested is a species of balancing. This would be inappropriate. The court has no warrant for second-guessing the legislature either about what counts as a good effect (provided the legislature is not aiming at something forbidden, which gets us back to the purpose inquiry), or about the valuation of the good effect (for example, how much diversion of business a certain improvement in Oregon's litter problem is worth), or about just how much of the good effect is actually achieved. For that matter, the court has no basis for deciding how bad is what would have to be regarded as the bad effect in a balancing analysis, namely the diversion of business; we have established in discussing the concept-of-union objection that protectionist effect (diversion of business) is not a constitutional disvalue in itself.

In response to my claim that diversion of business is not a constitutional disvalue in itself, the reader might retort that it has to be some sort of disvalue, else the efficiency objection to protectionism makes no sense at all; and if it is some sort of disvalue, is there not reason for the court to see that it is only incurred with adequate justification? The reader's assumption that diversion of business must be some sort of disvalue is plausible but mistaken. The premise of the efficiency objection ("this law diverts business without ...") is not so much an assertion of the disvalue of diversion of business as it is a very weak presumption in favor of the economic status quo. But this presumption is so weak that it can be overcome by any legislative preference for a different economic situation, so long as that preference is not based on an impermissible purpose. It is easy to see that the presump- 
tion cannot properly be any stronger than this. The economic status quo is itself the product of a host of legislative decisions, some of which, considered individually, will have diverted business out-of-state just as others no doubt diverted business in-state. Whatever new law is presently under review is not the first legislative intrusion into a previously unregulated economy. So, any presumption in favor of the status quo presupposes that what legislatures do is generally all right. The same presumption ought to attach to the new law unless there is some specific complaint to be made against it; and its merely altering the status quo, even in a way that is incidentally harmful to foreign business, quite obviously cannot be such a complaint. If this seems to leave the efficiency objection a mere shadow of itself, my answer is that that is all it deserves to be.

So, the efficiency objection does not require the court to identify and evaluate good effects and balance them against the diversion of business. There is, however, a much more limited task that the reader might still suggest the court should undertake. Perhaps the court should investigate the effects of the statute only to the extent of confirming that there is some actual effect (in some degree) that might be regarded as a good effect. It is important to see that this is not a balancing inquiry. If the court decides there is some effect from the statute that the legislature might permissibly have evaluated positively, then the inquiry is at an end.

Now, this test as it stands is no test at all. Every law will produce some effect the legislature might permissibly have evaluated positively. We can assert of any law that it passes this test without even looking at the law's actual effects. The test would cease to be vacuous if we required that the law produce some good effect the achievement of which was among the legislature's articulated purposes. But there is no good general ground for requiring legislatures to articulate their purposes; ${ }^{74}$ and in any event, if the articulated purpose is the real purpose, the probability of the law's achieving the articulated purpose to some degree is so high that it is not worth the judicial effort to confirm some good effect. Legislatures do not miss the broad sides of barns.

Despite what I have said, I agree that it is often worth looking to see whether the law achieves anything that is among the legislature's articulated purposes. The reason is that this is a useful step in smoking out illegitimate purpose. If the law seems to achieve nothing, or even very little, in the way of its articulated purpose (if it has one) or

74. See J. Ely, Democracy and Distrust: A Theory of Judicial Review 125-31 (1980); Linde, Due Process of Lawmaking, 55 NEB. L. REv. 197, 222-35 (1976). 
in the way of any plausible permissible purpose we can imagine for it, that is evidence that the law was passed with bad purpose. So, for that matter, is the fact that the law diverts business in-state, if the diversion is significant. Thus it is really concern with purpose that both grounds our weak presumption in favor of the economic status quo and that inclines us to check whether the law produces some good effect.

In sum, we cannot and should not replace the inquiry into purpose with any inquiry into the effects of a law, not even the most limited inquiry and not even for purposes of the efficiency objection. Inquiry into effect is relevant, but only as an aspect of the inquiry into purpose.

It remains to consider what feature of protectionism is crucial for the resentment/retaliation objection. Our conclusions here cannot be so definite as in connection with the other two objections, because we are dealing in part with the psychological reactions of "victim" states against whom protectionism is directed. Even here, however, it is clear that purpose is the most important variable.

Protectionist purpose will certainly inspire resentment in victim states, probably even in the unlikely but imaginable case where the protectionist purpose produces no protectionist effect. Explicitness and protectionist effect will also tend to inspire resentment, if only because they will be taken as evidence of protectionist purpose. This evidentiary significance of explicitness and effect is not something we can ignore, but let us set it aside for a moment. If we assume that victim states somehow know with certainty whether or not a law has been passed with protectionist purpose, will they resent explicitness or protectionist effect in themselves, in cases where they know purpose was absent?

Explicitness, I think, will not be resented for itself. Illinois nineteen-year-olds may resent Wisconsin's law explicitly excluding them from Wisconsin bars even if they understand that the motive is comity; but the State of Illinois will not resent the law.

Protectionist effect, however, may be resented for itself. If the Oregon bottle law costs Washington bottlers business, the State of Washington may resent the law even though it concedes that Oregon had no protectionist purpose. It may feel that Oregon is too finicky about its environment and is insufficiently sensible of the merits and deserts of hardworking bottlers.

Still, even if protectionist effect may be resented for itself, it seems less likely to cause resentment, and likely to cause less resentment, than protectionist purpose. Protectionist purpose involves a pure preference for local residents on the part of the legislating state; protectionist effect arising from a law without protectionist purpose does not. 
The victim state will also be less resentful if it reflects that it sometimes passes laws for its own nonprotectionist purposes that have some protectionist effect. And if resentment is not much weakened by this reflection, the impulse to retaliate ought to be, since one does not wish to set an example of retaliation for something one may do oneself in the future.

Let us now relax the assumption that victim states will know for certain whether seemingly protectionist laws are motivated by protectionist purpose. Recognizing that explicitness and protectionist effect will be taken by victim states as evidence of protectionist purpose and will tend to inspire resentment for that reason, let us ask how this affects the appropriate judicial response to explicitness and protectionist effect.

Explicitness, in a law that has the general form of a tariff or embargo or the like, is very strong evidence for protectionist purpose, both from the point of view of the victim state and from the point of view of a reviewing court. Laws that look like explicit tariffs (or whatever) are rarely the natural way to achieve innocent purposes. Indeed, the courts would probably want to adopt a very strong presumption against explicit tariffs and the like without reference to how victim states will respond to explicitness as evidence of purpose. Considering just the concept-of-union objection and the efficiency objection, and considering the significance of explicitness as evidence of bad purpose just from the courts' point of view (as opposed to the less disinterested point of view of the victim states), it is still easy to conclude that explicit tariffs and the like should be "virtually per se illegal." (This mildly oxymoronic phrase comes from Justice Stewart's opinion in Pike v. Bruce Church, Inc. ${ }^{75}$ )

In support of the per se rule there is not merely the statistical point that explicitness in a law will reflect bad purpose much more often than not; there is the equally important point that the existence of the per se rule will stop many explicit laws with bad purpose from being passed. Indeed, this forestalling effect of the per se rule may have the consequence of weakening the purely statistical argument for the per se rule. It may be that some substantial fraction of those explicit tariffs or whatever that are actually passed in the teeth of the per se rule have an innocent purpose. Even so, the forestalling effect, and our assumption about what the statistics would be in the absence of the per se rule, justify having the rule.

For myself, I would stop with a "virtual" per se rule. I would not

75. 397 U.S. 137,145 (1970). 
make explicit tariffs and the like absolutely illegal. There is room for innocent explicit embargoes, as we have seen. ${ }^{76}$ In order to preserve the forestalling effect of the per se rule, we should put a heavy burden on the state that would persuade a court of the innocence of its purpose. I should say that an explicit tariff or whatever should not be upheld unless the state shows by clear and convincing evidence that its purpose was innocent. One could argue for a stricter or more complex standard short of total prohibition of explicitness (in tariffs and the like), but I shall not pursue the matter. Before one moved very far from the standard I have suggested, it would be clear we should just make the per se rule absolute and have done with it.

While we are discussing the per se rule against explicitness, notice a different, important point. No criterion stated in terms of explicitness, not even an absolute prohibition on explicit embargoes and the like, can be our only criterion of judicial review. States can achieve almost any desired discrimination by some ingenious nonexplicit law. There must therefore be some further test.

It may seem that in this discussion of the per se rule we have wandered a bit from the precise question at hand, namely the significance of victim states' responses to explicitness as evidence. We have wandered a bit - but with the purpose of showing that we would want to impose a rule against explicitness, which is highly relevant to dealing with victim states' likely responses, even without referring to those responses as justification for the rule. The one question that remains (consideration of which will get us firmly back on our path) is whether consideration of the victim states' responses justifies making our per se rule absolute.

To my mind, consideration of the victim states' responses does not justify an absolute rule against explicit tariffs and the like. (I cannot claim to feel strongly, however, that an absolute rule would be a mistake.) To be sure, if we permit any explicit tariffs (or whatever), we run the risk of creating resentment. Even though evidence that convinces a court of the enacting state's innocence ought to tend to convince a victim state as well, it is nonetheless the victim state whose ox is gored; the enacting state may persuade the court without persuading the victim. So, resentment is possible even after judicial supervision has done all it will. Still, the occasions will be rare (since explicit laws will rarely be upheld); the resentment ought to be palliated by at least

76. A class of cases in which explicit import embargoes have been often upheld are the quarantine cases. For my view of these cases and why they are consistent with my general approach, see the discussion of City of Philadelphia v. New Jersey, 437 U.S. 617 (1978), in section III.D. infra, especially the text following note 463 . 
some doubt about whether it is justified; and retaliation will in any event be forbidden.

Protectionist effect cannot be treated like explicitness. It cannot be made virtually per se illegal. It cannot even be the subject of a strong negative presumption. There are just too many possible laws that are within the states' power on any reasonable standard and that have some protectionist effect.

Of course significant protectionist effect will always be evidence of protectionist purpose. Although it does not follow from this that significant protectionist effect must lead to a finding of bad purpose unless there is opposed evidence of good purpose, the state that passes a law with significant protectionist effect would be well advised to offer the court some innocent explanation. Still, to treat protectionist effect as evidence of purpose is to admit that the ultimate question is about purpose, not effect.

Now, not forbidding protectionist effect absolutely has the same consequence regarding resentment as not forbidding explicitness absolutely. There will be occasions when the court is persuaded the protectionist effect results from an innocent purpose but the victim state is not. On such occasions, the law will be upheld, and it will be resented. Because laws with protectionist effect will be upheld more often than explicit laws, there may be more occasions for this resentment than for resentment caused by explicitness (though of course it should be easier to persuade the victim state that there was no bad purpose when the evidence for bad purpose is protectionist effect than when the evidence is explicitness, for the same reasons it will be easier to persuade the court). Does the greater danger of resentment here suggest that we should do more with protectionist effect than just treat it as evidence of bad purpose? Should we, for example, say that a law with significant protectionist effect is invalid unless that effect is justified by counterbalancing good effects actually achieved by the law?

I think we should not. I have commented on the defects of the protectionist effect balancing approach in a different context just a few pages back. Beyond that, the need for balancing is not great. The occasions for resentment will be infrequent if the courts do their job properly and if victim states are not obsessively self-involved. And retaliation will be forbidden in any event. Even if we went beyond the purpose inquiry and engaged in protectionist effect balancing, there would still be occasions when the reviewing court was persuaded a law was justified and the victim state was not so persuaded. Given the uncertainty about what protectionist effect balancing could amount to, it 
is not even clear that it would reduce the frequency of disagreement between court and victim state.

In sum, we can attempt to minimize resentment and we can see that resentment does not issue in retaliation, but we cannot hope to eliminate all possible occasions for resentment. If we reconcile ourselves to that fact, there is no strong reason to give protectionist effect more than evidentiary significance, at least so long as we prescind from any doubts we may have (we, not victim states) about judicial competence to ascertain legislative purpose.

So far, we have been focusing on the resentment aspect of the resentment/retaliation objection. But it is the cycle of retaliation, and further retaliation by the original enacting state, and so on, that poses the greatest danger to the nation's political life. We should therefore notice that although there is no necessary conceptual connection between purpose and resentment (because even unintended protectionist effect may be resented), there is a necessary conceptual connection of a different sort between retaliation and purpose. To say that a victim state "retaliates" is to say that it acts with hostile purpose, whether the retaliation is directed against protectionist purpose or against mere explicitness or effect. Retaliation by the victim state in the form of protectionist measures therefore has protectionist purpose. So, in order to suppress the cycle of retaliation, which is the greatest problem, it suffices to suppress laws with protectionist purpose. The first attempted retaliation will be such a law. There is no reason even to consider treating protectionist effect as anything but evidence in this connection.

The discussion to this point strongly indicates that if our basic worry is protectionism, then it is protectionist purpose we really care about. Unless there is some good general objection to judicial review of legislative purpose, the desire to suppress state protectionism should lead the Court to a rule against laws passed with protectionist purpose. The rule will be implemented in part by a very strong presumption against explicit embargoes and the like. Protectionist effect will matter only as evidence of protectionist purpose. As evidence, protectionist effect may matter a great deal, since effect is often the best evidence of purpose. But purpose will be the key.

Whether there is any good general objection to judicial review of legislative purpose is the topic for section II.B. But before we turn to that, let us consider briefly whether our notion of protectionist purpose needs refining. 
We have said that a law has protectionist purpose if it was adopted for the purpose of improving the competitive position of local economic actors, just because they are local, vis-à-vis their foreign competitors. Now, the phrase "adopted for the purpose of . . ." is ambiguous. It can refer to an ultimate purpose or a merely intermediate purpose. For example, I might put on my shoes in the morning for the purpose of going to the grocery store to buy a loaf of bread. But going to the grocery store to buy bread is not my ultimate purpose. My ultimate purpose is to have toast for breakfast. Notice that even though going to the grocery store is only an intermediate purpose, a means to a further purpose, there is nothing odd about saying I put on my shoes for the purpose of going to the store. (The locution "for the purpose of ..." is a bit fancy for the context, but perfectly appropriate in meaning.) So, when we talk about doing something for the purpose of something else, the something else may be either an intermediate purpose or an ultimate one. Our definition of protectionist purpose would therefore seem to say that a law has protectionist purpose if it was adopted for the purpose of improving the competitive position of local actors, whether that competitive improvement was the ultimate purpose or only an intermediate purpose.

There is no doubt that a purpose to improve the competitive position of local actors (which I shall refer to for the present as a "protective purpose") can logically be merely intermediate. For example, a tariff passed to protect an infant industry has a short-term protective purpose. But the legislature that passes it could claim that the ultimate long-term purpose is not local advantage but the promotion of efficient production. Infant industries aside, a protective tariff might in some circumstances be defended as a means to short-term efficiency - the legislature might claim the tariff counteracts a local consumer preference for high-cost foreign manufactures that is based on an illusory belief in their superior quality. Even a tariff that makes no pretense of promoting efficiency might be cloaked in an innocentsounding ultimate purpose. The legislature might claim, say, that the local economy is particularly depressed in comparison to the rest of the country and thus deserving of special consideration.

The observation that protective purpose might be merely intermediate brings with it a further realization, that when we discussed how protectionist purpose grounded the three objections to protectionism, we were implicitly assuming that protectionist purpose was an ultimate protective purpose (or at least that the ultimate purpose was a bare transfer of welfare). If the protective purpose is not ultimate, the 
objections may not apply. Consider: Long-run efficiency, short-run efficiency, and perhaps even redistribution of welfare to particularly needy areas are federally cognizable benefits. So in the examples I have described where the protective purpose is intermediate, the law is not inefficient in our sense (it aims ultimately at a federally cognizable benefit), and it is arguably perfectly consistent with the concept of union. The protective purpose might still provoke resentment and retaliation. But even so, the law escapes two of the three objections to protectionism.

The question now is, should we restrict our definition of protectionist purpose to exclude these cases and others we might imagine, by stipulating that we have "protectionist purpose" only when there is protective purpose and when that protective purpose (or the bare transfer of welfare from foreigners to locals that it entails) is the ultimate purpose of the law, unsupported by any further claims about efficiency or special need?

I think we should not restrict our definition in this way. We should regard protective purpose as triggering the constitutional ban on protectionism whether it is the ultimate purpose or merely an intermediate purpose. The main reason is that if we do not - if we say that a claim of innocent ultimate purpose beyond the protective purpose can save the state law - we will be creating a range of defenses that are relevant to virtually every instance of protective purpose. Observe the difference between claiming a law with protectionist effect was actually passed to protect the local environment and claiming it was passed to protect an industry that needs protection only in the short run, or claiming the beneficiaries are particularly needy. The claim about environmental protection can be dismissed out of hand unless the law has something to do with the environment. This claim cannot be trotted out in every case, or in many cases, to hide a bad purpose. But the claims that protection is only for the short run (or whatever) can be trotted out in defense of almost any law at all. These all-purpose defenses of protective laws would significantly increase the burden of judicial review. They would also probably produce the very hardest cases for judges on the issue whether the claimed innocent motives were genuine. Finally, the availability of these defenses would invite self-deception by legislators much more than does the possibility of hiding protectivist motivation under a disguise of concern for the environment, or whatever. The all-purpose defenses should not be recognized. ${ }^{77}$ (Having decided that we should ban protective purpose

77. The Court rejected an infant industry defense in Bacchus Imports, Ltd. v. Dias, 468 U.S. 263 (1984), discussed in section III.D. infra. 
whether it is ultimate or merely intermediate, I shall revert to calling it protectionist purpose, which now expressly means "protective purpose, ultimate or intermediate," as the definition always suggested.)

What the possibility of genuine infant industry cases and the like does suggest is that perhaps Congress ought to be able to authorize protectionist state laws - in other words, the doctrine of Prudential Insurance Co. v. Benjamin. ${ }^{78}$ Protectionist measures that aim at nothing but a bare transfer of welfare to the enacting state are unlikely to win Congress' approval; and so long as Congress permits protectionism only rarely, retaliation and counter-retaliation cannot get out of hand.

The doctrine of Prudential v. Benjamin should not be deduced unthinkingly from the fact that the commerce clause is in terms a grant of power to Congress and is thus an odd source for a restriction on Congress. We have seen that the dormant commerce clause embodies national values that even Congress should not ignore. These values were expounded in the structural argument developed in subsections II.A.1. and II.A.2. And if, as I suggested in the brief textual argument at the end of subsection II.A.1., the framers' main object in granting Congress power over interstate commerce was to disable the states from certain sorts of regulation, then it is reasonable to conclude both that the framers recognized these values and that they did not mean to invite Congress to ride over them roughshod.

A part of me that believes strongly in judicial review wants to say that if we have the doctrine of Prudential v. Benjamin, the Court should at least reserve a residual power to see that Congress does not abuse its freedom to authorize protectionism. But that may not be realistic. In any event, if the infant industry defense and related defenses of protectionism are to be recognized at all, it is Congress that should do it. The Court should not recognize these defenses if Congress is silent. ${ }^{79}$

We have considered one respect in which our definition of protectionism might seem too broad. Let us turn now to another.

Our definition of protectionism covers legislation that improves the competitive position of local consumers vis-à-vis foreign consumers. Consumers compete with each other, from the point of view of economic theory; and there is nothing in the definition to exclude them from coverage. The definition also covers legislation designed to guar-

78. 328 U.S. 408 (1946).

79. For further observations on the Prudential doctrine, see section II.F. infra at note 175; section II.H. infra at notes 238-40; and section III.D. infra at notes 501-03. 
antee local actors special access to local natural resources. Again, this is a possible form of local preference, and there is nothing in our definition to exclude it. But neither protecting local consumers nor guaranteeing locals special access to local natural resources is part of what we might think of as the historical core of protectionism. So it is worth asking whether these types of protectionism really ought to be covered by our definition, or whether the definition should be narrowed. Notice that protection of consumers and guaranteeing local actors access to local resources are logically separable matters; either can occur independently of the other. But they often occur together, as in the recent Oklahoma minnow case, ${ }^{80}$ and they raise similar issues for present purposes.

With regard to both consumer protectionism and resource protectionism (as I shall call them), we can argue that the standard objections to protectionism do not apply with full force.

Consumer protectionism seems inconsistent with the concept of union, in some ideal sense; but if consumer protectionism is not traditionally disfavored, or is viewed with ambivalence, then it is to that extent not inconsistent with our operative concept of union. Also, consumer protectionism threatens inefficiency from the economist's point of view; but what it threatens is inefficiency in distribution, not production, and it is efficiency in production that people opposed to protectionism normally focus on. ${ }^{81}$ Finally, consumer protectionism may be less likely than other sorts of protectionism to produce focused resentment and a political impulse to retaliate, just because consumers as a group are less likely to be organized politically than farmers, manufacturers, or workers.

As to resource protectionism, we seem to have some idea that citizens of a state have a special claim on the state's natural resources. To the extent that idea has force, resource protectionism is not inconsistent with the concept of union and is less likely to provoke resentment or hostility.

On the other side, theoretical simplicity argues in favor of not excepting consumer and resource protectionism. After all, we did not

80. Hughes v. Oklahoma, 441 U.S. 322 (1979).

81. Indeed, all of our formulations of the efficiency objection to protectionism, which talked of diverting business away from presumptively low-cost producers, presupposed that it was efficiency in production we were thinking about. Even so, the generalization of the efficiency objection that would be necessary to make it relevant to consumer protectionism is completely obvious. To state the objection, not in its general form (which would have to be a bit ungainly), but in a form directly applicable to consumer protectionism: (Consumer) protectionism is ineffcient because it diverts goods away from presumptively high-utility consumers without any colorable justification in terms of a federally cognizable benefit. 
formulate our definition of protectionism specifically to include them. We formulated a natural, simple definition to cover the obvious standard cases of protectionism, and we discovered that consumer and resource protectionism were covered by that natural formulation. Also, to say the objections to protectionism do not apply to these two cases with full force is not to say they do not apply at all. Our concept of union, and consequently our inclinations to feel resentment at acts inconsistent with that concept, are to some degree fluid. They can respond to theoretical insight by expanding to cover cases other than the cases from which the theory started.

If I were a Supreme Court Justice confronting as a matter of first impression the question whether consumer and resource protectionism are forbidden by the Constitution, I do not know how I would come out. Neither including these forms of protectionism under the constitutional ban, nor excluding them, would be obviously wrong. But in fact, this is not a matter of first impression. It is already settled by existing decisions of the Court that both consumer protectionism and resource protectionism are forbidden by the dormant commerce clause. ${ }^{82}$ As long as that is theoretically reasonable doctrine - and it is - I shall tailor my definition of protectionism to reflect it - and I have. No revision of the definition is necessary.

Let us now quickly review the argument of this section of the essay (that is, all of section II.A.). We have set out the case against state protectionism from the point of view of someone writing a federal constitution. We have established that the crucial aspect of traditional protectionism is the protectionist purpose. We have decided upon reflection that our original definition of protectionist purpose is satisfactory; it picks out correctly the laws that our general concern with protectionism leads us to want to forbid. ${ }^{83}$

As we said some pages back - unless there is a good general ob-

82. E.g., New England Power Co. v. New Hampshire, 455 U.S. 331 (1982); Hughes v. Oklahoma, 441 U.S. 322 (1979); Pennsylvania v. West Virginia, 262 U.S. 553 (1923). Notice that what is forbidden is consumer and resource protectionism, no more. The Court has made it clear that so far as the dormant commerce clause is concerned states can tax and regulate natural resources as they please, provided only that they do so even-handedly. See, e.g., Commonwealth Edison Co. v. Montana, 453 U.S. 609 (1981) (discussed in sections II.D., II.F., III.B., and III.C. infra); Cities Serv. Gas Co. v. Peerless Oil \& Gas Co., 340 U.S. 179 (1950) (discussed in section III.C. infra). With regard to the special and unsettled problem of access to state-owned natural resources, see the discussion in Varat, State "Citizenship" and Interstate Equality, 48 U. CHI. L. REV. 487, 554-60 (1981), with which I am in general (not necessarily complete) agreement.

83. I remind the reader that the original definition of protectionist purpose may have been modified very slightly by a stipulation about the purpose of revenue-tariffs and analogous laws. I explained that stipulation in subsection II.A.1. (text following note 61 supra), even as I argued that the stipulation was probably not necessary in light of other features of my theory and the facts about legislative behavior. 
jection to judicial review of legislative purpose, the anti-protectionism principle is properly embodied in the doctrine that state laws are invalid if and (so far as anti-protectionism is in issue) only if they were motivated by protectionist purpose as we have defined it. ${ }^{84}$

\section{B. In Praise of Motive Review, Particularly Under the Dormant Commerce Clause}

(Before we begin, a note on terminology. In this section I shall use the phrase "motive review" instead of "purpose review," even though I have previously talked of purpose. "Motive review" is both better entrenched and more euphonious than the alternative. There is no useful distinction to be made between motive and purpose in the present context. ${ }^{85}$ )

Throughout its history the Court has engaged sporadically in motive review; ${ }^{86}$ but lately it has been unusually forthright about it. ${ }^{87}$ The commentators these days generally approve. ${ }^{88}$ Given this happy concurrence of Court and commentators on the propriety of motive review in certain areas, I am tempted to treat it as settled that there is no good general objection to motive review. Nonetheless, I shall pause over the question of the propriety of motive review, for two reasons.

First, I want to emphasize the positive case for motive review. Proponents of motive review now argue nearly unopposed, but they still tend to argue from a defensive posture, which makes the case for motive review seem weaker than it is.

Second, I want to emphasize that the specifics of the arguments for and against motive review depend on the area of law we focus on. Little attention has been paid to the dormant commerce clause in the

84. I must mention yet again that discussion of the state-as-market-participant cases is postponed to section II.G. infra.

85. See Ely, Legislative and Administrative Motivation in Constitutional Law, 79 YALE L.J. $1205,1217-21$ (1970).

86. See id. at 1208-12. For earlier indications, consider the quotation from McCulloch $\mathbf{v}$. Maryland, 17 U.S. (4 Wheat.) 316 (1819), discussed in the text at note 104 infra; Willson v. Black Bird Creek Marsh Co., 27 U.S. (2 Pet.) 245 (1829); and Lochner v. New York, 198 U.S. 45 (1905).

87. The most striking development has been the emphasis on purpose in (constitutional) discrimination cases. Personnel Administrator v. Feeney, 442 U.S. 256 (1979) (sex); Village of Arlington Heights v. Metropolitan Hous. Dev. Corp., 429 U.S. 252 (1977) (race); Washington v. Davis, 426 U.S. 229 (1976) (race). For a recent case in which the Court relies explicitly and solely on motive review to invalidate a state law under the establishment clause, see Wallace v. Jaffree, 105 S. Ct. 2479 (1985).

88. E.g., J. ELY, supra note 74, at 136-45; Brest, Palmer v. Thompson: An Approach to the Problem of Unconstitutional Legislative Motive, 1971 SUP. CT. REV. 95; Clark, Legislative Motivation and Fundamental Rights in Constitutional Law, 15 SAN DIEgo L. REV. 953 (1978); Ely, supra note 85; Simon, Racially Prejudiced Governmental Actions: A Motivation Theory of the Constitutional Ban Against Racial Discrimination, 15 SAN DIEgo L. REV. 1041 (1978). 
recent literature on motive review; but in my opinion the justification for motive review in this area is unusually strong.

The most important point in favor of motive review is this: From the point of view of the constitution-writer, who is attempting to define for herself, in abstraction from particular legislative problems, what the legislature ought and ought not to be able to do, it turns out that in some areas motive is precisely the crucial variable.

For example, we have seen already that motive is the crucial variable for the constitution-writer attempting to formulate for herself the prohibition she wants to impose against state protectionism. Let me restate our main conclusions briefly, with an eye to facilitating comparison between the reasons purpose is central in dealing with protectionism and the reasons it is central in certain other areas.

Explicitness is not the crucial variable - both because there are some laws the constitution-writer would want state legislatures to be able to pass despite their explicitness, and, more important, because even a total ban on explicit embargoes and the like would not constrain clever legislatures enough.

Effect is also not the crucial variable. A total ban on laws with protectionist effect would constrain state legislatures much too much. Nor will the constitution-writer want to say, even just to herself, that a state legislature can pass a law with protectionist effect if and only if the law has good effects that outweigh the protectionist effect. This balancing presupposes that the protectionist effect and the good effects can be assigned reasonably definite values. But the constitution-writer would deny that such an assignment of values is appropriate even in principle. With regard to what is supposed to be the negative side of the balance, the constitution-writer would understand that there is no reason to regard protectionist effect as a constitutional disvalue in itself. Nor is it possible to assign definite values to the good effects on the positive side of the balance. The good effects are things like a litter-free environment, better treatment for retail gasoline dealers, freedom from unwanted door-to-door solicitation, ${ }^{89}$ and so on. The whole point of having legislatures is to allow them to decide how these effects should be valued, after the constitution-writing stage. And the whole point of having fifty separate state legislatures is to allow one state to value these effects differently than another.

What the constitution-writer finds she can say, and wants to say, is that state legislatures must not pass laws motivated by protectionist purpose. It is the possibility of protectionist purpose dressed up in

89. As in Breard v. Alexandria, 341 U.S. 622 (1951). 
neutral terms that makes a mere prohibition on explicit embargoes and the like inadequate; stating the prohibition in terms of purpose solves that problem. On the other hand, a prohibition stated in terms of protectionist purpose does not interfere with the state legislatures' freedom to value the ordinary goals of legislation as they will. Protectionist purpose seeks no federally cognizable good; it seeks only a transfer of welfare from foreigners to their local competitors, which is an improper goal for a state in the context of federal union. Let the state avoid this improper goal, and it can do what it wants (subject, of course, to other constitutional limits having nothing to do with protectionism). In sum, bad motive is just what the constitution-writer would want to focus on.

Let us now compare protectionism with race discrimination, another area where the Court engages in motive review. ${ }^{90}$ Once again, there are three main variables we might build a test on: explicit racial classification, racially discriminatory purpose, and racially discriminatory effect ("disparate impact").

In dealing with race discrimination, just as in dealing with protectionism, it obviously is not enough to forbid explicitness. In both areas, however, we make a beginning on the problem with a "virtual per se rule" against explicitness. (With regard to race, we say race is a "suspect classification.") Are the reasons for this virtual per se rule the same in both areas? Not precisely. In connection with protectionism, I have argued already that explicit classification by reference to state lines is not a constitutional disvalue in itself. We presumptively forbid explicit embargoes and the like because explicitness is all but conclusive evidence of bad purpose. In contrast, the history and present state of our society with regard to race give us good reason to treat explicit racial classification as constitutionally disvaluable in itself. ${ }^{91}$ It is this which accounts for the extraordinary strength of the presumption against (non-affirmative action) racial explicitness.

As previously noted, we must do more than simply forbid explicitness. The choice for further action is between forbidding bad motive and forbidding disparate impact. (We could have both a motive test and an impact test; but the adoption of either makes the other less necessary and therefore less appealing.) If we forbid bad racial motive, we can forbid it absolutely. Racial disparate impact, in contrast, we cannot forbid absolutely any more than we could forbid protectionist effect absolutely. If we forbid racial disparate impact, we must for-

90. See note 87 supra.

91. Cf. Brest, The Supreme Court, 1975 Term - Foreword: In Defense of the Antidiscrimination Principle, 90 HaRv. L. REv. 1 (1976). 
bid it only presumptively, and we must stand ready to engage in balancing that allows a real possibility of justification (unlike the "balancing" triggered by racial explicitness). The Court has opted to forbid bad racial motive and to treat racial disparate impact as no (constitutional) disvalue in itself, but only as evidence of motive.

I am inclined to think this is the right solution, as it is in connection with protectionism, but again the different subject matter makes some difference. There is no case at all, in my opinion, for treating protectionist effect as a disvalue in itself. But there is a good deal to be said for treating racial disparate impact as a disvalue in itself, at least at present. Arguably any law that tends in any way to exacerbate the racial polarization of our society ought to bear a special burden of justification. So, people who are unhappy with the Court's decision to focus on bad racial motive to the exclusion of disparate impact (in constitutional law) have some reason to be unhappy - much more reason than they have to be unhappy with the parallel choice regarding protectionism.

There are many other areas aside from race discrimination where the distinguishable but connected problems arise of whether the Court should engage in motive review and whether, if it does so, it ought to engage in some form of balancing review as well. In addition to other areas of anti-discrimination law, there are the areas of freedom of speech and the establishment of religion. But I shall not stop to comment on those areas. In pausing over race discrimination at this point, my object has been merely to give some indication of how the propriety and adequacy of motive review depend on the specific area of law we are dealing with. I have not exhausted what could be said even about the comparison between protectionism and race discrimination. Indeed, I shall make occasional further comments about that comparison as we proceed. But no present purpose would be served by branching out into other areas, however important and interesting they are in themselves.

I have argued that the constitution-writer would want to define her objection to protectionism, at least for herself, in terms of motive. But of course the constitution-writer must speak in the end to legislatures and courts (among others). My readers are probably impatient to get on to the question of whether motive review is appropriate for courts; but we should pause for a moment over a logically prior matter.

As Hans Linde has reminded us, the commands of the Constitution are addressed primarily to legislatures. ${ }^{92}$ The business of the

92. Linde, supra note 74 , at $206-07$. 
courts (when they are engaged in judicial review) is to see that legislatures do their duty. It follows that the Court's standards for reviewing legislation ought to suggest (in fact, ought to originate in) prescriptions for legislative behavior that it is reasonable to expect legislatures to comply with. The requirement of avoiding protectionist purpose is such a prescription, and that is another positive argument for motive review.

I do not say it is easy for an individual or for a multimember body always to be sure just what its purposes are. On occasion, another person or body (perhaps a court?) may even be a better judge of true purpose. Still, there is no doubt about the appropriateness of instructing a person or a legislative body to take care for its purposes, and most especially to avoid forbidden purposes so far as it can. Doing one's best not to aim at what is forbidden is part of any conception of responsible agency. We would want to adjure legislatures to keep to permitted purposes even if we thought legislative motive was judicially unreviewable. ${ }^{93}$

In contrast, judicial balancing of a law's benefits against its protectionist effect does not reflect a proper underlying prescription for legislative behavior. A legislature may quite properly adopt a law without specifying precisely what it expects in the way of benefits and indeed without a detailed inventory of expected effects good or bad. Furthermore, if protectionist effect is not a constitutional disvalue in itself, the legislature is in no better position than the constitution-writer to assign protectionist effect an "appropriate" negative value for balancing purposes. In short, the legislature need not and cannot balance, and the Court should not adopt a mode of review that suggests the legislature should have balanced.

We turn now to the question whether legislative motive is really meet for judicial review. Let us consider first what is known as the "ascertainability" problem: Can a court really figure out what the legislature's motive was? Others before me have argued that the court can figure out the legislative motive well enough, ${ }^{94}$ and of course I agree. But in keeping with my program of making the positive case for motive review, I will go further and assert that motive review is a much more appropriate exercise for a court to engage in - it is a much more judicial enterprise - than the only alternative, which is some sort of balancing. ${ }^{95}$

93. Cf. Brest, The Conscientious Legislator's Guide to Constitutional Interpretation, 27 STAN. L. REV. 585, 589-91 (1975).

94. E.g., Brest, supra note 88, at 119-24; Simon, supra note 88, at 1097-1107.

95. Cf. Brest, Reflections on Motive Review, 15 SAN Diego L. REv. 1141, 1143-44 (1978). 
(At this point a third alternative may suggest itself. The court could eschew both straightforward motive review and balancing in favor of what I have called the "hypothetical innocent legislature test." That is, the court could ask itself, "Is it plausible to suppose that a state legislature might have passed this law without being motivated by protectionist purpose?" I shall argue later on that this alternative is specious - that no one could accept the consequences of this test's being taken seriously and applied honestly. For now, let us put the hypothetical innocent legislature test to one side.)

Before pursuing the ascertainability issue, I should formulate precisely the question I would have the court ask itself when it is engaged in motive review under the dormant commerce clause, and I should specify the standard of proof. In my view, the court should strike down a state law if and only if it finds by a preponderance of the evidence that protectionist purpose on the part of the legislators contributed substantially to the adoption of the law or any feature of the law. 96

Only two aspects of this formulation, the meaning of "contributed substantially" and the appropriateness of the "preponderance of the evidence" standard, will require any extended discussion. As to the other elements: "Protectionist purpose" means of course protectionist purpose as we have defined it. I add "on the part of the legislators" (a qualification I shall not bother to repeat hereafter) to emphasize that lobbying pressure from local interests favoring protectionism is not itself enough to invalidate a law. The question is whether legislators shared the protectionist purpose. The legislators might have passed the law for other, permissible reasons. "Legislators" and "laws," of course, include any government body or official and any of their actions that come under judicial scrutiny. Finally, the reference to "any feature of the law" merely reminds us of my earlier conclusion that the anti-protectionism principle applies both to the law as a whole and to individual features of the law. 97 This also is something I shall generally leave implicit as I talk about applying the purpose test to "laws."

Now, as to "contributed substantially." The main point of the "substantial contribution" test is to avoid requiring the court to look for a sole or dominant legislative motive. It is obvious why we do not limit ourselves to concern with protectionist purpose that is the sole motive for a law (or feature); protectionist purpose can be influential

96. Yet again I must note that the state-as-market-participant issue is held in abeyance. Also, the test stated in the text assumes the law under review does not discriminate explicitly by state lines, so our per se rule against explicitness is not triggered.

97. See the two paragraphs of text immediately preceding note 62 supra. 
enough to be objectionable without being unalloyed. It is less obvious that we should not be looking for dominant motive. To be candid, I would not be troubled by looking for dominant motive. I think the inquiry is manageable, and I suspect that if people kept in mind that the anti-protectionism principle applies not just to the law as a whole but to any feature of the law, the consensus against looking for dominant motive would evaporate. The "any feature" provision makes it unnecessary to speculate, for example, about whether the dominant motive of some tariff taken as a whole was revenue or protectionism. It suffices that protectionism is the dominant motive of the discriminatory aspect. But inquiry into dominant motive has such a bad press that I shall not argue for it here. ${ }^{98}$

Aside from the fact that a motive can "contribute substantially" to the adoption of a law (or feature) without being the dominant motive, what else can I say about how much contribution is substantial? Not much. This is the sort of question where precision is impossible. I can say this: the fact that some motive is a but-for cause of the adoption of the law (or feature) is not sufficient to make that motive count as contributing substantially. If only one legislator out of many is motivated by protectionist purpose, then protectionist purpose does not contribute substantially even though that legislator's vote is crucial. Is it then necessary that the protectionist purpose be a but-for cause before it counts as making a substantial contribution? Yes and no. No, in the sense that the court should not be required to ask in every case whether the protectionist motive was a but-for cause and to invalidate the law only if it can find that it was. Yes, in the sense that if the state can persuade the court that protectionist motivation which appears to have contributed substantially was not a but-for cause - that is, if the state can persuade the court that the adoption of the law was overdetermined and that the legislature would have done just what it did even if protectionist motive had been completely absent - then the

98. E.g., Brest, supra note 88, at 119-20; Ely, supra note 85, at 1213-14, 1266-68. Since I say in the text that I would be willing to state the test in terms of dominant purpose (even though in the end I do not), let me mention two explanatory points. First, my willingness to require dominant purpose applies to the dormant commerce clause area. It might not apply to other areas, such as race, for reasons alluded to in the text immediately following note 100 infra. Second, a purpose can be the dominant purpose of a law without being the dominant purpose of a majority of the legislators who vote for the law. Thus, if a few legislators want some law for protectionist reasons and many other legislators vote for the law just to go along with their colleagues, the dominant purpose of the law is protectionist. Similarly if all of the legislators voting for the law do so because their constituents want the law on protectionist grounds and the legislators just want to stay in office. The point of these examples, which I shall not elaborate, is that some possible purposes of individual legislators (going along with a colleague, staying in office) are not even candidates for the status of "the purpose of the legislature" or "the purpose of the law." And what ultimately counts as the purpose of the legislature or the purpose of the law must first be a candidate for being that purpose. 
law should be upheld. Needless to say, this is a hard thing for the state to prove.

It might occur to the reader to wonder whether a test stated in terms of substantial contribution as opposed to dominant motivation is fully congruent with the argument against protectionism in section II.A. If protectionist purpose only contributes substantially to the adoption of a law, there may be other substantial, permissible purposes as well; and that requires some weakening of the claim that what we count as protectionist legislation (or some feature thereof) is inefficient in the sense of aiming at no independent good. But so long as protectionist purpose contributes substantially to the adoption of the law (or feature), even the enacting legislature has not unambiguously endorsed the law (or feature) as achieving any independent good. Given the other objections to protectionist purpose, which are weakened hardly at all by requiring only substantial contribution, it seems proper to strike down the law on the substantial contribution test.

Paul Brest has suggested that a law should be invalidated if an impermissible purpose "played an affirmative role in the decisionmaking process" or if it "may have affected the outcome of the process."99 Given the unavoidable imprecision of attempts to say how much influence of an impermissible purpose is too much, I am not certain that Brest means to require less influence than I do, but it would appear that he does. If so, this may reflect another difference between race discrimination (on which Brest focuses) and protectionism. Certainly a law should not be invalidated because of a trivial suggestion of bad purpose. (On this Brest and I agree. ${ }^{100}$ ) Considered as a mechanism for generating political choices, the legislative process rarely produces a perfect run. But when it comes to saying how much of bad purpose is too much, we may well think it more important where race is involved that the process appear to be free of bias at any level that rises above the trivial or that threatens at all to affect results.

So much for what counts as substantial contribution; let us consider now the standard of proof. I have suggested that the standard of proof of bad motive, at least when the motive in question is protectionism, should be the preponderance of the evidence. Here also I differ from Brest, who argues for a "clear and convincing evidence" standard. ${ }^{101}$ To some extent, Brest's exacting standard of proof may be intended to offset his low threshold for the degree of influence of bad

99. Brest, supra note 88 , at 130,131 .

100. Id. at 119 ("nontrivial").

101. Id. at 130 . 
purpose. (Actually, there seems to be some internal tension in Brest's position that a law should be invalidated if it is shown by "clear and convincing evidence" that impermissible purpose "may have affected the outcome.")

There is another possible explanation of the disagreement between Brest and myself about the standard of proof, again tied to the difference between race discrimination and protectionism. A purpose to harm or demean one race is not only constitutionally impermissible, it is also morally wicked. Therefore, one might well think that before a court imputes bad racial purpose it should be unusually sure of its ground. Protectionist purpose, while it is constitutionally forbidden, does not seem wicked. Most people would probably think the legislator who promotes protectionism is no more than understandably and forgivably overzealous in pursuit of his constituents' interests. If so, there is no reason for the courts to be specially reluctant to impute protectionist purpose.

The feeling that protectionist purpose is understandable and forgivable reflects in part the fact that protectionism is a permanent temptation to which state legislatures give in remarkably frequently considering the clarity of the prohibition against it. That fact itself argues against an extraordinary standard of proof such as the "clear and convincing" standard. The "clear and convincing" standard would be more appropriate when an act of Congress is under review (say, when the question is whether Congress forbade the burning of draft cards in order to suppress criticism of the Viet Nam War ${ }^{102}$ ), since Congress is relatively conscientious about its constitutional responsibilities. As I have said before, the appropriateness and the proper implementation of motive review may vary with the context.

So, my claim (suppressing mention of niceties I said I would suppress mention of) is that a court should invalidate a state law if it finds by a preponderance of the evidence that protectionist purpose contributed substantially to the adoption of the law.

I see no reason to think courts cannot manage this inquiry into purpose. Courts regularly inquire into legislative purpose in the course of interpreting statutes. There are many sorts of evidence that can be brought to bear on the question of purpose, over and above the often powerful evidence of effect and even in the absence of recorded legislative debates or explicit statements of bad purpose. I shall not repeat the details of arguments others have already made. ${ }^{103}$ There is

102. Cf. United States v. O'Brien, 391 U.S. 367 (1968).

103. See authorities cited in note 94 supra. 
of course no mechanical procedure for uncovering and weighing the evidence relevant to legislative motive, and different people looking at the same record may come to different conclusions. Even so, the intractability of the issue has been overstated.

The fact is, this is just the kind of problem courts are best at. Courts must ascertain the purpose with which some agent (individual or corporate body) acted in many areas of law - criminal law, contracts, trusts and estates, income taxation, to say nothing of ordinary statutory interpretation. In deciding what was the agent's purpose, the court does not need to inquire into the effects of the act beyond asking in general terms what sort of effects the agent probably expected. Nor does the court need to value the effects beyond asking how the agent appears to have valued them. In short, the court does not need to consult either the future or its view of social morality. The court needs only to look at something that was done in the past and to interpret what was done in light of the surrounding events and judicial knowledge of the proclivities of the sort of agent involved. Such projects are the judge's daily fare.

Chief Justice Marshall himself pronounced explicitly in favor of judicial review even of Congress' motives, in a passage from $\mathrm{McCul}$ loch v. Maryland that is widely reproduced but insufficiently appreciated: "[S]hould Congress, under the pretext of executing its powers, pass laws for the accomplishment of objects not entrusted to the government; it would become the painful duty of this tribunal, should a case requiring such a decision come before it, to say that such an act was not the law of the land." ${ }^{104}$ It is possible, in considering this quotation, to be bemused by the ambiguity of the word "objects," which could conceivably refer either to legislative purposes or to something like dealings with specified subject matters of regulation. There is no ambiguity, however, about the word "pretext." A pretext is precisely a cover for a purpose one wishes to hide. Marshall is talking about motive review.

A paragraph back, when I noted that motive review did not require courts to predict uncertain future effects and also did not require courts to value such effects, I was of course implicitly contrasting motive review with balancing, which requires both of those things. There is a standard case against judicial balancing, oft repeated, which convinces those who are already convinced and leaves others unmoved. I shall not belabor the standard case. But even here, I think there are a few significant points that often go unnoticed. It is a commonplace

104. McCulloch v. Maryland, 17 U.S. (4 Wheat.) 316, 423 (1819). 
that legislatures have better resources for ascertaining legislative facts than do courts (although legislatures do not always use well what they have). It is also frequently noticed that a state's legislators are likely to have, collectively, more accumulated direct acquaintance with many social and economic systems than judges do. It is rarely remarked, however, that the legislature has a further advantage, if it behaves wisely. It can choose its own time for acting on any particular problem. It can postpone acting until it knows as much as it wants to know. The court exercising judicial review, in contrast, must act when a case appears before it. The court cannot (or cannot regularly) put off decision just because it would like more facts than the parties have presented or more time to think.

Another commonplace is that we think attaching values to social and economic consequences is something normally best done by legislatures. That would be true even in a unitary system. But, as I have suggested, it is specially inappropriate for any body other than Congress to attempt to evaluate from a national point of view effects that we have specifically chosen, by having a federal system, to leave to varying state evaluations in the normal course.

The standard defense of balancing is that, for better or worse, courts do it all the time and we really could not get along without it. In support of these claims, the balancer points both to judicial review under, say, the first amendment, and to accepted common law judicial lawmaking. Now, I agree that courts engaged in judicial review balance frequently (or at least say they are balancing frequently). ${ }^{105} \mathrm{I}$ also agree that in some areas we truly cannot dispense with judicial balancing. For example, the first amendment value of free speech requires special judicial protection, and certain hard cases cannot be decided without balancing of some sort. But the fact that we accept balancing in some areas does not vitiate the case against balancing. It proves only that sometimes there is a stronger case still in favor of balancing. We should balance where balancing is necessary, and only there. Balancing is not necessary to enforce the constitutional command against state protectionism, which calls directly for motive review. In this area, therefore, we should not balance. ${ }^{106}$

105. Indeed, courts balance or claim to balance even more frequently than many of us may realize. See Aleinikoff, Constitutional Law in the Age of Balancing, 96 YALE L.J. (forthcoming).

106. Someone might suggest that the objections to balancing are less if what is in question is not case-by-case balancing but rather "definitional balancing," which uses balancing arguments to justify categorial rules. I agree that where balancing is inevitable, definitional balancing has some important advantages, mainly in terms of clarity and the avoidance of "chilling" effects. But with regard to their own capacities, courts are no better situated to announce categorial rules on balancing grounds than they are to decide individual cases on such grounds; indeed, because of the way information reaches courts, they may be worse situated for definitional balancing. In 
Incidentally, the claim that judicial lawmaking under the common law involves balancing is mostly just not true. The courts that made the greatest common law revolution of this century, culminating in the modern law of products liability, were not balancing. They were responding to the perception that it was unfair for manufacturers to send goods into the marketplace without bearing any responsibility for harm those goods caused if defective. Even the commentators' contribution, the argument that manufacturer liability encourages efficient accident avoidance, can be adopted by courts without detailed inquiry into or evaluation of particular effects. And there was no need to balance efficiency against fairness, since they point the same way. Even to the extent common law judicial lawmaking does involve balancing, it is still less problematic than a balancing approach to the dormant commerce clause. Common law judicial lawmaking, expansive as it is, deals with a range of issues more within the judge's knowledge than the issues raised by state laws regulating commerce (if these laws are treated under a balancing mode of review). One reason is that common law judges have a power that we have mentioned legislatures have and judges exercising judicial review do not have, namely, the power to select the problems they will make far-reaching decisions about.

All of this adds up to the conclusion that motive review is a much more appropriate judicial enterprise than balancing, at least for implementing the dormant commerce clause's prohibition of state protectionism. And we can summarize a good bit of the argument in a way that emphasizes the parallelism between the reasons courts should prefer motive review and the reasons the constitution-writer would focus on legislative motive in formulating her own view about the proper scope of legislative power: in each case, the object is to place limits on the legislature without displacing the legislature from making those judgments it can make best.

Let us consider now the "hypothetical innocent legislature test." I shall not examine in detail what circumstances should trigger the test and how precisely it should be formulated - the problem with the test is not a matter of detail. I shall assume that whenever a law with nonnegligible protectionist effect is challenged on dormant commerce clause grounds, the court is to ask itself, "Is it plausible to suppose that a state legislature might have passed this law without being significantly motivated by protectionist purpose?"

any event, there is no suggestion of definitional balancing in the dormant commerce clause opinions. Even the per se rule against explicitness should not be understood as an instance of definitional balancing, as I shall explain in the discussion of Pike v. Bruce Church, Inc. in section III.A. 
It is important that the question is framed in terms of " $a$ " state legislature, and not "this" state legislature. The whole point of the test is to avoid motive review, to avoid looking at the actual legislature's actual purpose.

Now, the proponent of the hypothetical innocent legislature test must claim that the test will produce much the same results as straightforward motive review. The test is proposed as a substitute for motive review, after all. The proponent of the test admits that motive is what the constitution-writer would care about - specifically, the actual legislature's actual motive. But to avoid judicial inquiry into actual motive, we adopt the indirect, hypothetical approach.

Unfortunately, the hypothetical innocent legislature test fails totally as an approximation of ordinary motive review in certain circumstances. As long as the courts treat actual motive as relevant (and the Court has said sufficiently often that actual protectionist motive is relevant), ${ }^{107}$ application of the hypothetical innocent legislature test to the cases that actually arise, with their actual records, would produce much the same results as ordinary motive review. But if the Court abandoned motive review in favor of the hypothetical innocent legislature test, then different cases would arise, with different records, and as applied to some of these cases, the hypothetical innocent legislature test would have disastrous results.

Consider Exxon Corp. v. Maryland, ${ }^{108}$ in which the Court upheld a law forbidding producers or refiners of petroleum to own retail service stations in Maryland. The Court plainly thought the Maryland legislature was innocent of significant protectionist motivation. A fortiori, the Court found it plausible to suppose that some state legislature might have passed the law without significant protectionist motive. So the Court would have upheld the law under the hypothetical innocent legislature test. But now suppose the hypothetical innocent legislature test were the Court's announced criterion for review. Once the Maryland law had been upheld, every other state legislature would be free to pass the same law, and to pass it openly and expressly as a protectionist measure. If we take the hypothetical innocent legislature test seriously, which means we do not concern ourselves with actual motive, the Court would be committed by its upholding of the Maryland law to uphold all these other instances of avowed protectionism.

107. The famous Pike test itself requires that a state law have "a legitimate local purpose," with the strong implication that protectionism is not such a purpose. Pike v. Bruce Church, Inc., 397 U.S. 137, 142 (1970). What the Pike test lacks in absolute explicitness (as a condemnation of protectionist motive) it makes up for in ubiquity.

108. 437 U.S. 117 (1978). 
Not all states would choose to exploit the opportunity for open protectionism now offered them, but some would. And the legislatures would not merely have no reason to conceal their protectionist motivation; they would have positive reason to avow it. They would want to be sure of getting full political credit from those the protectionism benefits. This is surely unacceptable.

Notice, incidentally, that we cannot reconcile ourselves to the upholding of all these protectionist laws by saying there is no harm in upholding laws that have good effects on balance even if they were passed for bad reasons. The Court, if it upholds the Maryland law under the hypothetical innocent legislature test, has not held that the law has good effects on balance, or indeed that it has any good effects at all. The Court has only held that some state legislature might have thought so.

The mildly paradoxical conclusion is this: The hypothetical innocent legislature test seems like an appealing substitute for motive review only so long as it is not the Court's actual criterion of review. If it once became the actual criterion of review, its inadequacy would be revealed in short order.

The hypothetical innocent legislature test is a sham in other ways as well. If it is to be any test at all, it must sometimes invalidate a state law. Sometimes, that is, the court must be willing to say, "It is not plausible to suppose a state legislature could have passed this law without bad purpose." But that entails, "It is not plausible to suppose this legislature could have passed this law without bad purpose," which is tantamount to saying the legislature under review had bad purpose. So, whenever a court invalidates a law under the hypothetical innocent legislature test, it will in effect be finding that the actual legislature had an actual bad motive and it will be offering whatever insult such a finding involves. Such a finding and such insult are just what the hypothetical innocent legislature test is supposed to avoid. What is worse, the court that takes the test seriously will be making the finding and offering the insult without doing the legislature the courtesy of looking to see whether inspection of the legislature's actual decision process, so far as it is discoverable, might change the court's mind.

What this all adds up to is the not very surprising lesson that if what we are ultimately concerned about is bad motive, it is foolish to close our eyes to direct evidence of the legislature's decision process just because such evidence will often be inconclusive. When the direct evidence is sparse or nonexistent, motive review will effectively reduce to the hypothetical innocent legislature test. But when the direct evi- 
dence has some weight - and I emphasize that it can point either way - it is wrong to ignore it.

This discussion of the hypothetical innocent legislature test suggests a positive argument for motive review that we have not previously noted. One effect of motive review is to encourage legislatures that are acting on impermissible motives to conceal their motives. Alexander Bickel thought this disincentive to candor was a defect of motive review; ${ }^{109}$ and given the general value of candor on the part of government officials, any sensible person must have some inclination to agree. But candid avowal by legislators of bad motives is not necessarily a good thing.

Whether courts engage in motive review or not, legislators will not often avow bad motives that in addition to being bad are unpopular with their constituents. So, avoiding motive review is not likely to produce the happy result of a legislature's revealing its bad motives to an electorate who thereupon throw the rascals out. What legislators will be candid about, if there is no motive review, is bad motives that their constituents approve of. This candid avowal may have various undesirable effects.

Candid avowal of bad motives by legislators may reinforce the bad motives of their constituents. This was surely one effect of the railing against integration by the Mayor of Jackson, Mississippi, before he closed the swimming pools in 1963.110 Candid avowal of bad motives may also hurt or offend the people against whom the bad motives are directed. And, as we have noted, candid avowal of bad motives may increase the likelihood that the badly motivated legislators get political credit from their badly motivated constituents, thus reinforcing the legislators' bad motives. All in all, candor about bad motives may be something we should discourage. Just consider: If the Court had been willing to engage in motive review, the Mayor of Jackson could have railed against integrated pools, or he could (perhaps) have got away with closing the pools. He could not have done both. ${ }^{111}$

To finish off, I shall mention or discuss briefly some standard and some not-so-standard objections to motive review that $I$ have not yet touched on:

109. A. Bickel, The Least Dangerous Branch 216 (1962).

110. Cf. Palmer v. Thompson, 403 U.S. 217 (1971).

111. Justice $O^{\prime}$ Connor appears to make a similar point in her concurrence in Wallace $v$. Jaffree. Responding to the claim that motive review in establishment clause cases will merely encourage legislative dissimulation, $O^{\prime}$ Connor observes (in part): "It is not a trivial matter ... to require that the legislature manifest a secular purpose and omit all sectarian endorsements from its laws." 105 S. Ct. 2479, 2500 (1985) (O'Connor, J., concurring). 
The "futility" objection has been fully dealt with by Paul Brest."12

I would say the same about the "insult to the legislature" objection, ${ }^{113}$ except that Kenneth Karst has recently given that old objection a new and interesting twist. ${ }^{114}$ Karst argues, not that a court should be unwilling to point out bad purpose where it exists, but that courts will be unwilling to accuse a legislature of bad purpose when there is any room for doubt. Hence, if litigation focuses on purpose, legislatures will be given more freedom than they should enjoy, because of judicial scruples. Furthermore, if litigation focuses on purpose, it will be specially acrimonious, with accusations of turpitude met by outraged denial. The hostility engendered by such a controversy will embitter relations between parties who need ideally to work together on a continuing basis outside the courtroom - institutional plaintiffs like the NAACP and defendants like city councils and school boards.

These are weighty arguments in the context of race discrimination, where Karst raises them; they have much less weight as applied to protectionism. I have remarked already that protectionist purpose is not condemned morally as racist purpose is. Courts will therefore not be as reluctant to find the former as to find the latter (if the belief in the general impropriety of motive review is laid to rest). Karst's second point, about poisoning ongoing relations, also has less force in the protectionism context, where the parties are more various and out-ofcourt interaction less pervasive and less delicate. ${ }^{115}$

Turning to another matter, the most impressive recent argument against judicial inquiry into legislative purpose is an essay by Hans Linde, and in the course of the essay, Linde makes some observations about the difficulty of ascertaining legislative purpose. ${ }^{116}$ But the significance for us of those observations is much diminished if we remember the context in which they occur. Linde is not attacking motive review, at least not primarily. ${ }^{117} \mathrm{He}$ is attacking "rationality review," which proceeds by checking the "fit" of legislative means against some

112. Brest, supra note 88 , at $125-27$.

113. Id. at $128-30$.

114. Karst, The Costs of Motive-Centered Inquiry, 15 SAN DIEGo L. REv. 1163 (1978).

115. But cf. Kitch, supra note 5S, at 45 (suggesting that the inefficiency of state regulation of interstate commerce is mitigated by ongoing negotiation between state enforcement officials and regulated businesses).

116. Linde, supra note 74 , especially at 207-12.

117. Linde may be mildly ambivalent about motive review. He notes that even a Court nominally engaged in motive review can manipulate results by choosing what "purposes" it will see. Id. at 213. But at many points Linde appears to take the propriety of motive review (that is, invalidating laws which have impermissible purposes) for granted. E.g., id. at 212, 219, 221. 
judicially created canonical formulation of the legislative purpose. Linde is right that rationality review, if it is not a cover for some other form of review, ${ }^{118}$ is foolishness. But the main reason (and I think Linde would agree about this) is not the difficulty of divining legislative purpose. Rather, it is the indefensibility of attributing to the legislature a purpose to which their chosen means do not rationally conduce. ${ }^{119}$ Legislatures sometimes have impermissible purposes, and of course they sometimes act on false empirical assumptions. But, remembering that their purposes are usually complex, legislatures do not act irrationally, as rationality review defines rationality. This argument against rationality review obviously does not touch motive review at all.

Even though Linde is not attacking motive review, some aspects of his argument suggest possible objections to motive review beyond the standard ascertainability objection. For example, Linde emphasizes that state legislatures often do not agree on any clear statement of their purposes in passing a law and often fail to make any sort of record showing why they expect the law to promote whatever goals they have in mind. ${ }^{120}$ To point this out is not to criticize state legislatures; they have a perfect constitutional right to behave as they do, and there are good reasons for such an "unscientific" approach to lawmaking. Indeed, someone might object to motive review precisely on the ground that in effect it requires legislatures to make a record in defense of certain of their enactments.

To my mind, this objection to motive review has more force than some of the standard objections. But it has less force than may at first appear, and it does not overcome the arguments in favor of motive review. Motive review never requires the making of a record, strictly speaking. Failure to make a record is never grounds for invalidation in itself. Motive review requires the making of a record only in the sense that if there is no record rebutting an inference of bad purpose, certain state laws will be struck down. The laws that are imperilled by absence of a record are those laws, and only those laws, that carry such a strong suggestion of bad purpose on their face as to make it seem more probable than not, in the absence of other evidence, that they were substantially motivated by bad purpose. Very few laws, other than explicit embargoes and the like, satisfy this description. As

118. E.g., City of Cleburne v. Cleburne Living Center, 105 S. Ct. 3249 (1985); Reed v. Reed, 404 U.S. 71 (1971).

119. The classic exposition of this point is Robert Nagel's Note, Legislative Purpose, Rationality, and Equal Protection, 82 YALE L.J. 123 (1972).

120. Linde, supra note 74 , at 222-35. 
to those few that do, it seems reasonable that the legislature should have to offer some evidence of innocent motivation before such laws are sustained.

Linde's essay suggests another possible objection to motive review, the last I shall consider. In the course of his essay Linde appears to advance against rationality review the following argument: because of the vagaries of the process by which the legislature's purpose is identified, rationality review might lead to some statute's being upheld while an identically worded statute from another legislature was struck down. ${ }^{121}$ If this possibility of different treatment of identically worded statutes were a genuine objection to rationality review, it would be an objection to motive review as well, since motive review can plainly lead to such different treatment.

But Linde at least does not think that different treatment of identically worded statutes is an objection in itself. His own proposed theory of the "due process of lawmaking," which would have the court review certain aspects of legislative procedure, ${ }^{122}$ can produce just this consequence. So, of course, can balancing, since identically worded statutes can have different effects when passed in different states. In fact, our earlier discussion of the "hypothetical innocent legislature test" shows how disastrous it might be to have a test that could not lead to different treatment of identically worded statutes. To be sure, if we made it a requirement that any acceptable test treat identically worded statutes identically, we could find a test satisfying this requirement that was preferable to the hypothetical innocent legislature test. But any such test would be a very blunt instrument for dealing with the problem of bad purpose (or the analogous problem of deficient legislative procedure), and there is no adequate reason to impose the requirement.

\section{Against the Carolene Products Theory of the Dormant Commerce Clause and Open-Ended Private Interest Balancing}

Up to this point, I have been presenting what I regard as the fundamentals of dormant commerce clause theory. The discussion has been expansive, perhaps at times extravagant. In the rest of Part II, I shall be treating either opposing theories or else aspects of my own theory that, while they may be important, are in some sense peripheral. The discussion will be more succinct. I hope the reader who has

121. Id. at 211-12, 218-19.

122. Id. at $235-51$. 
followed me this far will be able to fill out the arguments for herself to the extent it seems necessary.

The basic idea of the Carolene Products ${ }^{123}$ theory of the dormant commerce clause is simple enough: When states adopt economic regulations that affect out-of-state interests, those out-of-state interests are likely to be shortchanged because they are not represented in the political process that produces the regulations. But everyone who is affected ought to be represented. Therefore we have judicial review of state economic regulation that affects out-of-state interests in order to give those interests "virtual representation."124

The Carolene Products theory of the dormant commerce clause fits neatly, of course, with the Carolene Products theory of judicial review in general, which has achieved considerable current popularity as the "process-based" or "representation-reinforcing" theory of judicial review. ${ }^{125}$ I regard the Carolene Products theory of judicial review in general as quite unsatisfactory, but I shall not discuss it here. I would have little enough to add to what others have said already. ${ }^{126}$ I shall assume that the Carolene Products theory of the dormant commerce clause gets little support from the general Carolene Products theory.

Even if we set aside the Carolene Products theory of judicial review in general, the Carolene Products theory of the dormant commerce clause is still worth discussing. The dormant commerce clause itself seems to embody some notion of judicial protection for out-of-state interests - some notion, one might think, of virtual representation for foreigners.

Now, in discussing the Carolene Products theory of the dormant commerce clause (which I shall refer to hereafter as just the "Carolene

123. The reference is of course to United States v. Carolene Products Co., 304 U.S. 144 (1938), especially its famous footnote four.

124. Carolene Products theorists of the dormant commerce clause include: J. ELY, supra note 74 , at $83-84$ (whence the phrase "virtual representation" in the present context); Eule, supra note 12 (preferring to rely on the article IV privileges and immunities clause, but still very much a Carolene Products theorist); O'Fallon, The Commerce Clause: A Theoretical Comment, 61 ORE. L. REv. 395 (1982); Tushnet, Rethinking the Dormant Commerce Clause, 1979 WIS. L. REV. 125. (In view of Tushnet's later criticisms of Carolene Products theorizing, see note 126 infra, it seems unlikely that this article represents his current view. It could still represent his view of the best sense to be made of the dormant commerce clause if the constitutional tradition made sense.)

125. The dominating statement of this approach is J. ELY, supra note 74 .

126. E.g., Ackerman, Beyond Carolene Products, 98 HARv. L. Rev. 713 (1985); Brest, The Substance of Process, 42 OHIO ST. L.J. 131 (1981); Laycock, Taking Constitutions Seriously: A Theory of Judicial Review (Book Review), 59 TexAS L. REv. 343 (1981); Sandalow, The Distrust of Politics, 56 N.Y.U. L. Rev. 446 (1981); Sandalow, Judicial Protection of Minorities, 75 MicH. L. Rev. 1162 (1977); Tribe, The Puzzling Persistence of Process-Based Constitutional Theories, 89 YALE L.J. 1063 (1980); Tushnet, Darkness on the Edge of Town: The Contributions of John Hart Ely to Constitutional Theory, 89 YALE L.J. 1037 (1980). 
Products theory," leaving the limitation to the dormant commerce clause understood), the first thing we need to do is to be clear about the scope of judicial review that the theory is supposed to justify.

The Carolene Products theorist might argue only for judicial application of the anti-protectionism principle as I have developed it. This would put him on solid ground, but it would rob his theory of any interest. Certainly the Carolene Products theory entails the anti-protectionism principle as a consequence. There would be no protectionist legislation (in my sense) if foreign interests were represented equally with the local interests they compete against. However, the idea of virtual representation is not necessary to justify the anti-protectionism principle. My own argument for the anti-protectionism principle made no use of the idea of virtual representation. (The idea that one state may not behave hostilely to another is a much more limited idea, as is the idea that state regulation producing protectionist effect must aim at some federally cognizable benefit.) If virtual representation is the central idea of the Carolene Products theory, then the Carolene Products theory is not necessary to ground the anti-protectionism principle, and acceptance of the anti-protectionism principle does not commit us to the Carolene Products theory.

The Carolene Products theory is interesting only if it entails more than the anti-protectionism principle - specifically, if it entails that economic regulation that affects foreign interests should be reviewed by courts applying a balancing methodology. Open-ended private interest balancing is what virtual representation requires, and it is what most Carolene Products theorists have argued for. ${ }^{127}$ (The balancing that is required is private interest balancing because it is private interests that are supposed to deserve virtual representation.)

Now, one problem with the Carolene Products theory is that if it justifies balancing at all, it requires balancing over a much broader range of cases than its proponents usually recognize. Justice Stone, the original Carolene Products theorist (in the dormant commerce clause area as elsewhere), suggested that judicial review would not be necessary if there were in-state interests functionally equivalent to the damaged out-of-state interests. ${ }^{128}$ Julian Eule suggests that judicial review is necessary only if out-of-state interests are disproportionately burdened. ${ }^{129}$ But neither of these restrictions is defensible. If any foreigners are harmed, then representation of those foreigners in the

127. Eule, O'Fallon, and Tushnet (as of 1979) all argue for balancing, with various wrinkles. Ely does not. See materials cited in note 124 supra.

128. South Carolina State Highway Dept. v. Barnwell Bros., 303 U.S. 177, 187 (1938).

129. Eule, supra note 12 , at $460-85$. 
political process of the enacting state might have shifted the political balance and prevented the adoption of the regulation. This is true even if there are already similarly burdened local interests, and even if these local interests are more heavily burdened than the foreign. Perhaps we can limit review to cases where the out-of-state damage is nontrivial in magnitude; but we cannot limit it by either Stone's criterion or Eule's consistently with the underlying idea of securing virtual representation for unrepresented interests. ${ }^{130}$

This means the Carolene Products theory requires review of laws no one would normally think of as requiring judicial scrutiny. If Minnesota adopts an advertising campaign to try to discourage smoking among its population, or if it forbids smoking in enough stores, offices, and places of public assembly to affect significantly the total number of cigarettes smoked, then the law should be judicially inspected to see that it does not unjustly harm tobacco growers in North Carolina. If a major city adopts a rent control ordinance, judicial review is required to protect the interests of people living elsewhere who might have moved to the city except for the increased difficulty of securing housing. ${ }^{131}$ If a state has a stingy workmen's compensation program that attracts employers, the courts must stand ready to consider whether representation in that state's legislature of foreign workers might not have produced a program that was more generous.

My last example might elicit the response that review is not required because the foreign workers are not objecting to the program as it exists so much as they are objecting to the state's failure to have a more generous program. This raises an interesting question about what counts as action by a state and what is a mere omission. But even if we could make that distinction perfectly clear, it would not help the Carolene Products theorist. On his theory, the courts ought to review legislative omissions as freely as they review positive legislative action. After all, representation of foreign interests would not result only in blocking legislation. Sometimes it would tip the balance in favor of legislation where none was otherwise forthcoming. Thus, under the Carolene Products theory, courts ought to be willing to pro-

130. O'Fallon, supra note 124 , at 409,413 , gets this point exactly right. To put the point in a general context: If we regard legislation as a procedure for weighing and combining pressures from constituents and generating laws which point in the direction of the resultant vector (the standard modern "pluralist" view) as opposed to regarding it as a procedure for considering all significant arguments and generating results which are right for the polity in some deeper sense (the classical view), then virtual representation of the classical sort defended in eighteenthcentury English parliamentary theory will not suffice (as the colonists thought it did not). Rather, the scheme of virtual representation must respond as accurately as possible to the sheer numerical magnitude of all affected interests.

131. This example is borrowed from Kitch, supra note 55 , at 31 . 
tect eastern interests by reviewing any western state's failure to prohibit industrial processes which cause acid rain. ${ }^{132}$

Carolene Products theorists tend to overlook the breadth of review required by their theory. They take for granted a range of cases that we would all recognize as standard dormant commerce clause cases, and they discuss the merits of their theory as applied to those cases. But that range of cases is picked out by a different implicit justification for judicial review, which Carolene Products theorists are not entitled to rely on to limit their theory's application. (Incidentally, if the Carolene Products theorist of the dormant commerce clause purports to deduce his theory from the Carolene Products theory of judicial review in general, then his situation is even worse. He cannot limit his focus to economic regulation or regulation with significant out-of-state economic effects. He must call for balancing review of any state regulation that has significant out-of-state effects of any kind.)

Now, even if the Carolene Products theory is much broader than its proponents usually recognize, what's wrong with that? What is wrong with that is just what is wrong with balancing everywhere. I have explained already why balancing is undesirable even though it is sometimes indispensable. ${ }^{133}$ The broader the scope of balancing, where it is not indispensable, the more undesirable it is.

Overbreadth, however, is not the most fundamental problem with the Carolene Products theory of the dormant commerce clause. The Carolene Products theory assumes that out-of-state interests really ought to be represented - the theory assumes it is a defect in our system that the system denies foreigners representation, as it is a defect if racial minorities or women are unrepresented or represented ineffectively. But that assumption is not warranted. Nonrepresentation of foreign interests follows from the simple fact that there are separate

132. I do not mean to conceal the fact that under my own purpose-based approach also, legislative omissions are reviewable in principle. An omission, like a positive action, may be impermissibly motivated. But because there are always plausible explanations for an omission in terms of permissible motives (such as the press of other legislative business), occasions for serious motive review of legislative omissions will be very rare. There is no comparable ground for claiming that challenges to legislative omissions can generally be ignored or quickly dealt with under a Carolene Products balancing test.

Just as a curiosity, it is worth noting that in a very real sense what the Court was reviewing in Kassel v. Consolidated Freightways Corp., 450 U.S. 662 (1981), was not the Iowa law against sixty-five-foot double-trailer trucks, but rather Iowa's failure (omission) to repeal that law. The Iowa Legislature at one point tried to repeal the law, but they were frustrated by a gubernatorial veto of the repealing act. The Governor's veto was therefore the determining cause of the failure to repeal the old law and permit sixty-five-foot doubles, and the Governor's motives were highly suspect, to say the least. See 450 U.S. at 666 nn.6 \& 7, 677 n.23.

133. See sections II.A. \& B. supra. 
states; and the existence of separate states, while it might be a defect in an ideal political system, can hardly be treated as a defect in ours.

I suggest that with regard to treatment by the states of out-of-state interests, our system embodies the following compromise between unlimited state autonomy and perfect national unity. The states may not single out foreigners for disadvantageous treatment just because of their foreignness. But, provided they do not single out foreigners, the states need not attend positively to the foreign effects of laws they adopt nor to the distribution between locals and foreigners of the benefits and burdens of those laws. "Singling out" foreigners does not necessarily involve explicitness. It does involve purpose. The state legislature that simply fails to attend to foreign interests or to any local/foreign distinction may do as it pleases. This is the message of the dormant commerce clause, as it is the general message of the privileges and immunities clause of article IV. ${ }^{134}$

Clearly, this is a compromise. If the states were perfectly autonomous, they would be free to single out foreigners for disadvantageous treatment. If, on the other hand, we had perfect national unity, there would be no states at all, except perhaps as administrative departments, and all interests throughout the nation would be taken into account in any significant legislative decision. Giving foreign interests virtual representation in the actual independent state legislatures may be thought of as an attempt to mimic a regime of perfect national unity. But in view of the compromise I have described, such "virtual" perfect unity is not required. ${ }^{135}$

The autonomy interest of the states that we protect by not requiring virtual representation may seem like just a freedom to harm foreigners with impunity so long as it is done by inadvertence. This is not an interest one can feel much enthusiasm for. But in fact, there is more at stake.

By not requiring state lawmakers to be always looking over their shoulders for foreign interests and always calculating the proportionate incidence of benefits and burdens, we make legislation a possible

134. Cf. Varat, supra note 82. The "no-singling-out" idea is discussed further in section II.D. infra; it is limited by the state-as-market-participant exception discussed in section II.G. infra.

135. Cf. Maltz, supra note 3, at 80 . Because Varat, supra note 82 , at 516 , also speaks of a federalist "compromise," it is worth noting that the compromise he is primarily concerned with is a ramification of the more basic compromise I am concerned with. I am presenting the principle that foreigners may not be singled out for disadvantageous treatment as a compromise between perfect state autonomy and perfect national unity. Varat tends to take this principle as obvious (and I do not really mean to disagree), and he then views this principle as compromised in favor of state sovereignty by the idea that the state may favor its own residents in distributing benefits, an idea which is relevant to my purposes only in section II.G. 
task for lawmakers with less expertise and less administrative support available to them than Congress has. We also avoid a massive transfer of power to the courts, federal and state. And we avoid the tendency to homogenization of values that commitment of economic regulation to the courts, under the general supervision of the Supreme Court, would tend to bring about. It is worth remembering that states can disagree about issues with significant interstate aspects for reasons having nothing to do with hostility to, or even indifference to, foreigners as such.

If the interstate costs of allowing states to pursue their own values without worrying about foreign effects become too great, Congress can intervene. But some interstate costs - even some costs that Congress would regard as unjustified except that they are too small to get Congress's attention - are worth tolerating in the interest of state, and legislative, independence.

(My talk of state autonomy might stimulate in the reader the thought that if states are allowed to pass laws with significant out-ofstate effects, that is an incursion on the autonomy of the other states which are affected. So we might argue for judicial review as a protection for the autonomy of those other states. This argument, that courts should protect other states' interests, falls between the stools of "private interest balancing" and "national interest balancing," but I shall discuss it, and reject it, at the end of section II.E., devoted to spurious national interests.)

Three final points:

(1) We have seen that the Carolene Products theory of the dormant commerce clause is interesting only if it entails more than antiprotectionism, that is, if it entails balancing review of the effects of laws. It is ironic that if we engage in effects review under the dormant commerce clause, we will be giving out-of-state economic interests more protection than the Supreme Court has deemed appropriate for racial minorities and women under the equal protection clause. ${ }^{136}$ of course, the Court may be wrong to limit itself to motive review where race or sex is involved; but it would be hard indeed for anyone who approves the Court's equal protection doctrine to argue for dormant commerce clause balancing.

(2) I suspect a major source of appeal of the Carolene Products theory of the dormant commerce clause is the belief that the Court is balancing and that the Carolene Products theory provides the best available justification for this judicial behavior. If the Court were bal- 
ancing in movement-of-goods cases, the Carolene Products theory probably would be the best justification. But we shall see in Part III that the Court does not balance in movement-of-goods cases. And in transportation cases, where the Court may balance, there is another and better justification available. ${ }^{137}$

(3) For all that I have said about a state being entitled to ignore out-of-state effects, I do not deny that interstate comity should prevent a state from passing a law which it knows will impose large costs outof-state and which secures only a trivial local benefit. In fact, interstate comity probably does prevent states from doing this. (Classical protectionist legislation, which states demonstrably are not prevented by comity from passing, is not a counterexample to my claim, since protectionist legislation produces mainly a transfer of welfare from foreigners to locals.) Interstate comity should be approved and encouraged, but it should not be judicially enforced in the present context. It should not be enforced by balancing for all the reasons we have discussed elsewhere in arguing against balancing; and there is no other plausible way to enforce it which would add anything in practice to the principle forbidding purposeful discrimination against foreigners, for which we already have other theoretical justifications. ${ }^{138}$

\section{Interlude: Variations on the Theme of Anti-Protectionism}

The astute reader will have noticed that the limiting principle on state laws that I put forward in section II.C. as the result of a compromise between complete state independence and perfect national unity

137. See section II.F. infra. It is worth mentioning that there is a certain amount of Carolene Products rhetoric in dormant commerce clause cases, from Barnwell (see text at note 128 supra) right up to Kassel v. Consolidated Freightways Corp., 450 U.S. 662, 675-76 (1981). This rhetoric is not pervasive; and it can be seen in context as nothing more than overbroad justification for suppressing protectionism or for protecting the national interest in an effective transportation network. Compare the discussion of the rhetoric of free trade and national economic union in section II.E. infra.

138. My colleague Richard Lempert suggested to me a possible standard for dormant commerce clause review which might be thought to embody the principle of comity: A state law which does not purposefully discriminate is nonetheless unconstitutional if it strains credulity to imagine that the law would have been passed if all the effects of the law, for good and ill, were felt in-state.

From a practical point of view I would have no great objection to this test if it were applied as stated, since I expect that it would make no practical difference whatever. Notice that this test is vastly more permissive than what we normally think of as balancing. Applied as stated, this test would allow the state the widest fairly imaginable range for making its own value judgments. Also, the result of a case under this test could not turn on any but the grossest determinations of actual effects. But I see no adequate theoretical justification for the test. And I would resist adoption of the test because of the possibility that it would be misapplied. Courts would be hard pressed to resist the inevitable temptation to preserve a recognized bit of doctrine from desuetude; and even if courts successfully resisted, litigants would be encouraged to engage in pointless litigation. 
is not exactly the same as the anti-protectionism principle I have hitherto espoused. In section II.C., I said that a state could not single out foreigners for disadvantageous treatment. I did not restrict this "nosingling-out" principle to forbid only singling out of foreign competitors of similarly situated locals. But the anti-protectionism principle is limited to purposeful attempts to advantage locals vis-à-vis foreign competitors. This is a clear difference between the no-singling-out principle and the anti-protectionism principle. The import of the difference can be clarified by two examples. (Both examples, as it happens, will be based on transportation cases, but that will not matter to the discussion.)

Consider a schematized version of the facts of Brotherhood of Locomotive Firemen v. Chicago, Rock Island \& Pacific Railroad. ${ }^{139}$ (I emphasize that the facts are altered and simplified; I am interested in a kind of case, not in this actual case nor in the Court's disposition of it.) The State of Arkansas had a full-crew law covering railroads that owned more than fifty miles of track. Short-haul railroads, with fewer than fifty miles of track, were exempted from the law's coverage. All of the exempted short-haul railroads were local operations. All but one of the covered long-haul railroads were interstate carriers.

If (contrary to what the Court believed) the Arkansas legislature had created the short-haul exemption for the purpose of sparing local railroads, just because they were local, from a burden imposed on interstate railroads, then the legislature would have been engaged in singling out foreigners as such for disadvantageous treatment. But even so, the legislature might not have been violating the anti-protectionism principle. They would not have been violating the anti-protectionism principle if short-haul railroads and long-haul railroads did not compete significantly in practice. Of course, the fact that there was no effect on competition would not mean that Arkansas had no motive at all for making a local/foreign distinction. The legislature might have been in favor of the extra safety achieved by full-crew requirements just so long as the burden could be imposed on foreign enterprise.

For a somewhat different case, consider a schematized version of Kassel v. Consolidated Freightways Corp. ${ }^{140}$ The State of Iowa forbade the operation in Iowa of sixty-five-foot double-trailer trucks, a widely used truck configuration. The Governor of Iowa supported the ban on the explicit ground that it diverted interstate truck traffic away from Iowa and into neighboring states. ${ }^{141}$ The costs imposed by interstate

139. 393 U.S. 129 (1968).

140. 450 U.S. 662 (1981).

141. 450 U.S. at 666 n.7, 677 n.23 (1981). 
trucking - traffic hazards, road wear, aesthetic pollution, and the like - were thus shifted to road users and taxpayers in neighboring states. This does not violate the anti-protectionism principle, since neither the road users of Missouri (as road users) nor the taxpayers of Missouri compete with their Iowa counterparts. But if the object of the Iowa law was just to divert some costs from Iowans to similarly situated Missourians, then the law violated the no-singling-out principle.

Note that the Iowa law against sixty-five-foot doubles does not unambiguously reveal a bad purpose on its face any more than does the Arkansas full-crew law. (I assume for the moment that a purpose that violates the no-singling-out principle but not the anti-protectionism principle is still a "bad purpose.") It is true that the law forbids sixty-five-foot doubles only in Iowa; but that limitation flows simply from the limits on Iowa's territorial jurisdiction. If the Iowa legislature believed that sixty-five-foot doubles should be forbidden everywhere, then its forbidding them only in Iowa would not constitute singling out of foreigners in any significant sense - not even if the effect of the law was to divert traffic into other states (which could forbid the long doubles also, but choose not to). If, however, Iowa did not believe sixty-five-foot doubles should be prohibited everywhere (and remember that Iowa consumers benefit to some degree from the use of long doubles for shipping through other states), but merely wanted to prohibit them in Iowa while they were used elsewhere, so that traffic diversion was an important goal, then the purpose was objectionable.

In a case like Kassel, it may be very difficult to distinguish between an innocent and an objectionable purpose. Statements by legislators about "getting these trucks off Iowa's highways," for example, should not by themselves be taken to show a diversionary purpose. But there is a kind of purpose that may exist here - a specific purpose to divert traffic into other states - that seems objectionable if it can be shown.

Perhaps, then, we should replace the anti-protectionism principle with the (broader) no-singling-out principle. Before I discuss whether that would be sensible, let me point out a still broader principle that might suggest itself, which I shall call the "no-hostile-treatment" principle.

The no-hostile-treatment principle would apply to a class of cases that escape the no-singling-out principle. Commonwealth Edison Co. v. Montan ${ }^{142}$ provides a current example. (Nothing I say will turn on

142. 453 U.S. 609 (1981). 
the fact that this is a taxation case. Parker v. Brown ${ }^{143}$ would serve equally well as an example, but it is less current and less well known.) Montana, which has a significant fraction of the nation's coal reserves, imposes a severance tax on coal ranging up to thirty percent of the contract price of the coal. Ninety percent of the coal mined in Montana is shipped out of state. The severance tax is perfectly neutral in its application; it makes no distinction between coal destined for instate and out-of-state use. But of course all the revenue from the tax goes into the Montana state treasury, where it will benefit primarily present and future citizens of Montana. It is therefore possible to regard the tax as a measure designed to exploit foreign coal users (because they are foreign) for the benefit of Montana citizens. The nohostile-treatment principle would forbid such exploitation.

The no-hostile-treatment principle is broader than the no-singlingout principle. It would be unnatural to describe the Montana coal severance tax as "singling out" foreigners for disadvantageous treatment, even if the tax is motivated by a desire to exploit foreigners as such. No foreigners are treated differently than locals who are similarly situated. Foreign and local coal users are treated the same (qua coal users). It is local citizens in general who are benefited at the expense of foreign coal users. But citizens and coal users occupy such functionally dissimilar roles that even if the latter are exploited to benefit the former, and even if we disapprove the exploitation, we would not describe it as "singling out."

Let me emphasize that I have brought up the Montana coal tax as a law that might violate the no-hostile-treatment principle and that thus reveals the greater breadth of the no-hostile-treatment principle as compared to the no-singling-out principle. I have not said the Montana tax does violate the no-hostile-treatment principle. I think it probably does not. Severance taxes are a standard type of tax. Montana almost certainly would have some severance tax on coal even if the proportion of coal going out of state were much less, and Montana cannot be denied all power to tax just because the coal goes mostly out of state. So, the real issue about whether the tax was hostilely motivated must be whether the level of the tax was substantially influenced by a desire to prosper at the expense of foreigners. (This issue is still not special to tax cases: compare the matter of setting the price of raisins in Parker v. Brown ${ }^{144}$ or setting the minimum wellhead price of natural gas in Cities Service Gas Co. v. Peerless Oil \& Gas Co. ${ }^{145}$ )

143. 317 U.S. 341 (1943).

144. 317 U.S. 341 (1943).

145. 340 U.S. 179 (1950). 
It is tempting to look at the high apparent rate of the tax and at the proportion of coal going out of state and to assume the tax rate just has to represent the rapacity of a state that has monopoly power in a resource other states need. Anyone who thinks the issue is that simple should read the sympathetic presentation by Mike McGrath and Walter Hellerstein of Montana's point of view. ${ }^{146}$ In general, figuring out whether a tax rate or a minimum price was substantially influenced by a desire to exploit foreigners as such is likely to be very difficult probably even more difficult than figuring out just what sort of attitude about traffic diversion underlies laws like Iowa's ban on sixty-five-foot double-trailer trucks.

We now have, in addition to the anti-protectionism principle, two broader variants: the no-singling-out principle and the no-hostiletreatment principle. On the other side of the anti-protectionism principle from these broader variants is a (narrower) principle we might call the "historically restricted anti-protectionism principle." I have mentioned that protectionism as historically conceived probably did not include either protection of local consumers or protection of locals' access to local natural resources. That is to say, probably only protection of local producers was condemned as protectionism, and probably even that was not condemned when it took the form of protecting local producers' access to local resources. The "historically restricted anti-protectionism principle" prohibits only laws falling under this narrow conception of protectionism. It does not forbid what we have called consumer protectionism and resource protectionism.

We can now set out a spectrum of possible prohibitions on state commercial regulation hostile to foreigners:

(1) the historically restricted anti-protectionism principle;

(2) the anti-protectionism principle proper, as we have defined it (in another context this might be called the "generalized competitionpreserving anti-protectionism principle");

(3) the no-singling-out principle; and

(4) the no-hostile-treatment principle.

These four principles form a hierarchy; they are listed in order of increasing breadth, and each is strictly included in its successor. ${ }^{147}$

146. McGrath \& Hellerstein, Reflections on Commonwealth Edison Co. v. Montana, 43 MONT. L. REV. 165 (1982).

147. Notice that as we move from (2) to (3) we incidentally leave behind any necessary restriction to what we would normally think of as commercial regulation. Whether we would wish to reimpose such a restriction on principle (3) or (4) if we adopted either of them is one of many further subtleties I shall ignore; I shall discuss only commercial examples. Even if we do not 
Notice that despite their differences all four principles involve motive review. Under all four principles it is purposeful discrimination against, or hostile treatment of, foreigners that is forbidden. Any of the four principles could play the role of the no-singling-out principle in the compromise between complete state independence and perfect national unity that I described in section II.C. Even the broad nohostile-treatment principle stops far short of the sort of judicial review required by the Carolene Products theory of the dormant commerce clause. The Carolene Products theory, with its idea of virtual representation, requires attention to foreign interests. But the legislature that simply does not attend to foreign interests cannot on that ground be said to treat foreign interests hostilely.

(Perhaps I should also mention that all four principles are limited, as the anti-protectionism principle is limited, by whatever idea it is that generates the "state-as-market-participant" exception, still to be discussed.)

Now, I think it is much more important that we adopt some one of these four principles, as opposed to the Carolene Products approach, than it is which one we adopt. Similarly, within this hierarchy of four principles, I think there is a much stronger case for adopting either (2) or (3), and thus for rejecting (1) and (4), than there is for preferring either of (2) or (3) to the other. In the end, of course, I tend to prefer (2) - the anti-protectionism principle as I have defined it.

I shall sketch very quickly my reasons for gradually paring down the choices within the hierarchy in this way. My arguments against the Carolene Products theory I shall not repeat.

The main objection to the historically restricted anti-protectionism principle is that the Court has plainly gone beyond it. The Court has struck down both consumer protectionism and resource protectionism. ${ }^{148}$ Also, the step from the historically restricted anti-protectionism principle to the anti-protectionism principle proper is an easy and natural generalization. Indeed, the exclusion of consumer protectionism and resource protectionism from the scope of the competition-preserving anti-protectionism idea seems arbitrary; it seems to have nothing but a reading of history to recommend it.

At the other end of the hierarchy, the no-hostile-treatment principle requires particular judgments about legislative purpose that are too hard to make. (Note that to say a court can reliably answer some

limit principles (3) and (4) to commercial regulation, they remain far less broad than the Carolene Products theory for reasons discussed immediately in the text.

148. See note 82 supra. 
questions about purpose, as I do, is not to say it can answer every question about purpose we think up.) In cases falling under the nohostile-treatment principle but not under the no-singling-out principle (cases like the Montana tax case), the chances of the court's being justified in finding substantial bad purpose are so small that it is better to foreclose consideration of such cases by rejecting the broader principle entirely. Also, we do not need the no-hostile-treatment principle to explain any Supreme Court decision. In fact, the Court seems to have rejected the principle implicitly by effectively ignoring the issue about purpose that accepting the principle would raise in the Montana tax case and other cases like it. ${ }^{149}$

A defender of the no-hostile-treatment principle might point out that in section II.C. I said a state could legislate as it pleased if it did not attend to the implications for out-of-state interests; and this defender might then observe that in cases like the Montana tax case it is simply impossible that the legislature should be totally unaware of the pattern of commerce in coal and thus of the special significance the tax has for foreign interests. But I never said nonattending to foreign interests was a necessary condition for the legislature's behavior to be acceptable. I said it was a sufficient condition, as it is (insofar as we are concerned with any variant of the anti-protectionism principle). Nor should we make nonattention to foreign interests a strictly necessary condition. If the legislature really cannot be totally unaware of the impact on foreign interests in a case like the Montana tax case, then in merely being aware of that impact it has not yet gone any distance out of its way to behave hostilely to foreign interests. The inevitable awareness of the foreign impact in cases like this is one of the things that makes the relevant purpose inquiry specially difficult. (Judicial balancing would not be a satisfactory way around the problem. It is hard to imagine a question less suited to judicial determination than the question what is a fair tax on coal or a reasonable price for raisins or natural gas.) ${ }^{150}$

So much for the principles at the two extremes of our hierarchy. As between the anti-protectionism principle proper and the no-singling-out principle, I prefer the former partly because of its closer connection with the historical notion of protectionism (the no-singling-out

149. See the cases discussed in subsection III.C.2. infra.

150. The fact that the Montana legislature must have been aware of the foreign effects of its tax means that I could distinguish the Montana tax case and cases like it from other cases where the foreign effects are not so obtrusive, and I could then give these "inevitable awareness" cases to the Carolene Products theorist. (That is, I could countenance balancing to protect foreign interests where legislative awareness of substantial foreign effects is inevitable.) I am not inclined to do this, nor has the Court done it. But such a position might appeal to some readers. 
principle is even more of a generalization), and partly because the questions about legislative purpose made relevant by the no-singlingout principle seem likely to be more difficult than the questions under the anti-protectionism principle. ${ }^{151}$ Also, the anti-protectionism principle is all we need to explain the Court's decisions. The only evidence of judicial adoption of the no-singling-out principle as opposed to the anti-protectionism principle is Justice Brennan's concurrence (signed also by Justice Marshall) in Kassel v. Consolidated Freightways Corp. ${ }^{152}$ But if the no-singling-out principle had been clearly unavailable, Brennan and Marshall could easily have joined in Justice Powell's plurality opinion, which rested on other grounds (specifically, on antiprotectionism in my sense and on transportation-balancing).

On the side of the no-singling-out principle, one might think it has greater theoretical integrity than the anti-protectionism principle. Why, after all, is discrimination against foreign competitors specially objectionable? And as to history, one might find the no-singling-out principle in the article IV privileges and immunities clause and one might then let the privileges and immunities clause swallow up the dormant commerce clause entirely. (My thoughts about that possibility I reserve for section II.H.)

As I have indicated, the choice between the anti-protectionism principle and the no-singling-out principle could plausibly go either way. Sometimes I even find myself preferring the no-singling-out principle. What I never doubt is that these two principles are the real candidates, with the no-hostile-treatment principle a distant third, just barely in the race.

\section{E. The Irrelevance of National Interest Balancing to Movement-of-Goods Cases}

Among the versions of balancing I discussed in the Introduction there were only two potentially wide-ranging forms of balancing: open-ended private interest balancing and national interest balancing. Open-ended private interest balancing we have already dealt with. The only remotely plausible justification for such balancing is the

151. I have in mind specifically cases like Kassel (though not Kassel itself) where a goal like "getting these dangerous trucks off our roads" is so perfectly ambiguous between the acceptable goal of "getting them off that portion of everyone's roads which is under our control" and the unacceptable goal of "getting them off our roads and onto someone else's instead." (This suggests a distinction we might make between Kassel and Brotherhood of Locomotive Firemen, and that distinction suggests a corresponding limited version of the no singling-out-principle; but that is another subtlety I shall not pursue.)

152. 450 U.S. 662,679 (1981) (Brennan, J., concurring). Another case that might be cited in this connection is Sporhase v. Nebraska ex rel. Douglas, 458 U.S. 941 (1982). On Sporhase, see section III.D. infra, especially note 472 . 
Carolene Products theory of the dormant commerce clause. In showing that the Carolene Products theory is untenable, we effectively excluded open-ended private interest balancing from the range of defensible possibilities.

National interest balancing we cannot reject so definitively. There may be cases in which national interest balancing is appropriate. But we shall see in this section that national interest balancing is not appropriate in movement-of-goods cases. There is no genuine national interest implicated in movement-of-goods cases that requires balancing for its vindication.

There is one genuine national interest implicated in movement-ofgoods cases, which we have already discussed at length. It is the interest in preventing state protectionism. But this national interest does not require balancing to vindicate it. State protectionism involves impermissible legislative purpose. No law should be struck down except on grounds of bad purpose; and if bad purpose is found, then the law should be struck down without worrying about what local interests it might promote. In short, no balancing is necessary.

(In the preceding paragraph I spoke of the "national interest in preventing state protectionism." What I now mean to refer to by this phrase is the national interest in preventing state behavior that purposefully and improperly disadvantages foreigners. This interest might be embodied in any of the four principles discussed in section II.D. Since all four of the principles focus on legislative purpose, what I have said about the lack of need for balancing remains true whichever of the principles we adopt. Hereafter I shall refer to the relevant national interest simply as the interest in avoiding state protectionism. Another point - there is an exception to the rule that if bad purpose is found the law should be invalidated forthwith. That is the exception represented by the cases on the state as market participant. But we shall see in section II.G. that even that exception does not involve the court in balancing.)

Aside from the interest in avoiding state protectionism, which requires no balancing, there simply are no genuine national interests involved in movement-of-goods cases. I shall consider a number of supposed national interests - such as the interest in efficiency, or the interest in uniform commercial regulation - and I shall explain why they are all spurious. Let me emphasize that in saying these supposed interests are not genuine national interests, I am not impugning the power of Congress to pursue them. Congress can of course legislate to promote efficiency, or to promote uniformity of commercial regulation, or whatever; and if Congress does so, then these become national 
interests in a sense, to the extent Congress has chosen to pursue them. What I am saying, when I deny that these are genuine national interests, is this: I am saying they are not interests with a constitutional status. They are not interests that require or justify judicial concern if Congress has not acted. They are not, in short, interests relevant to the dormant commerce clause.

In dormant commerce clause opinions and in the scholarly literature, there is much rhetoric about national interests in "economic nationhood," a "national common market," "free trade," the "free movement of goods," and "access to markets" or the freedom of a producer in one part of the country to send his products into any market in the country. These phrases are all ambiguous. Each of them could be taken to refer to nothing more than the national interest in avoiding state protectionism. One rhetorically satisfying way of decrying protectionism is to say it is inconsistent with economic nationhood. (I have said something like that myself.) Similarly with each of the other phrases. We can praise free trade or access to markets and mean nothing more than that trade or access should not be constrained by preferential local regulation. Unfortunately, if each of these phrases can refer merely to the absence of protectionism, each of them also suggests something more. And the rhetoric has acquired a life of its own. We have repeated the phrases so often we tend to assume they must mean something more than the absence of protectionism, at least if we do not pause to ask just what else they could mean.

Before I look at the phrases individually to show that none of them names any genuine national interest other than the interest in avoiding protectionism, let me comment on the origins of our current rhetoric. There are two opinions that are almost invariably cited when the rhetoric of economic nationhood or whatever is brought forward. They are Cardozo's opinion in Baldwin v. G.A.F. Seelig, Inc. ${ }^{153}$ and Jackson's opinion in H.P. Hood \& Sons v. Du Mond. ${ }^{154}$ But as I shall show in section III.C., Baldwin and Hood are both about protectionism as I have defined it. I am not saying just that the cases as limited by their facts are about protectionism. The opinions are about protectionism, and nothing more. Both Cardozo and Jackson produce some purple prose; but it is later judges and scholars who have taken Cardozo's and Jackson's phrases out of context and repeated them with almost no thought for what they might concretely mean, and certainly without ever giving them any concrete meaning beyond anti-protectionism.

153. 294 U.S. 511 (1935).

154. 336 U.S. 525 (1949). 
Now, turning to the specific phrases. Talk of economic nationhood and of a national common market tends to suggest that there is a national interest in uniformity of commercial regulation. But there is no such interest. Indeed, to suggest that there is such an interest, especially in view of the breadth of "commercial regulation" as we now understand it, is very nearly to make nonsense of the whole idea of federal union. The reason for having separate states is to allow diversity - diversity of commercial regulation as much as diversity in other spheres. Of course, diversity has its costs, and Congress exists in part to see that the costs of diversity do not become intolerable. But the most fundamental features of our polity are inconsistent with the idea that we value uniformity of state regulation just for the sake of uniformity.

Uniformity may in some circumstances acquire a derivative value, derivative from other national interests. For example, I shall suggest in section II.F. that there may be a genuine national interest in the existence of an effective transport system extending throughout the nation. The effectiveness of the transport system is endangered by certain nonuniform state regulation, such as varying state regulation of maximum train lengths. ${ }^{155}$ So there is some derivative national interest in uniformity of regulation of the means of transportation. But that does not suggest at all a national interest in uniform regulation in other areas. ${ }^{156}$

Turning to another of our phrases, talk of free trade suggests a national interest in economic laissez-faire. But that is a notion we buried in the 1930s. There is one form in which claims of a general right to be free from economic regulation still may have a sympathetic ring; that is when they appear as complaints about being required to change

155. Cf. Southern Pac. Co. v. Arizona, 325 U.S. 761 (1945).

156. In case it occurs to some reader to suggest that at least uniformity is desirable in areas where states just want to have some law but do not care about the precise content: The answer is that if states really do not care about the content, they will have no difficulty achieving uniformity by interstate agreement without judicial assistance. So there is still no argument for judicial review.

I shall make some further brief comments on the significance (or rather the irrelevance) of uniformity in connection with the discussion in section II.F. infra of the requirement that taxes on interstate commerce be fairly apportioned.

I have excluded international trade from the scope of this essay. But it is worth mentioning that even though there is no national interest in uniformity as such when we are talking about state regulation or taxation of interstate commerce, there could still be such an interest where state regulation or taxation of foreign commerce is involved. Cf. Japan Line, Ltd. v. County of Los Angeles, 441 U.S. 434 (1979). Of course, to say that the Court may have identified a genuine national interest in Japan Line is not to approve the Court's rather conclusory analysis of the case; nor is it to approve the Court's further casual assumption that because multiple taxation by the states of interstate commerce is an appropriate judicial concern (as I agree it is, see section II.F. infra) the same must be true of multiple taxation of foreign commerce caused by overlapping state and foreign tax schemes. 
an established way of doing business. Purveyors of beverages in metal cans complained that the Oregon bottle law would require them to restructure an entire industry. But there is no general constitutional right to be allowed to go on doing as one has done in the past, and there is no genuine national interest in allowing people to go on doing as they have done in the past. To recognize such a right or such an interest would be to say that almost all legislation requires judicial scrutiny; and that is just the claim we rejected a half century ago. Although talk of a requirement that legislation be rationally related to some permissible purpose lingers on, there is nothing in it. Every purpose is permissible that is not impermissible, and all legislation is rationally related to its actual purpose, which is usually complex. Courts sometimes strike down statutes under the "minimum rationality" test, ${ }^{157}$ but when they do so, it is pretense.

There is another sort of case that might suggest the Court attaches special disvalue to legislative interference with established behavior. Consider Hunt v. Washington State Apple Advertising Commission. 158 There the Court emphasized that the North Carolina statute would require Washington apple growers to change their packaging practices. But the real point was not that Washington growers would be required to change; it was that Washington growers would be required to change and that North Carolina growers would not. It was this differential impact that attracted the Court's special attention. ${ }^{159}$

Moving on to our next phrase, talk about the free movement of goods is multiply ambiguous. Like talk about economic nationhood or whatever, it may refer to nothing more than the national interest in avoiding protectionism. It could also refer to a national interest in the existence of an effective transportation network, which I have conceded may be a genuine national interest but which is not implicated in movement-of-goods cases. If "free movement of goods" is to refer to something other than these two interests, it must be to the idea that the movement of goods across state lines is worth encouraging in itself. The interest in the transportation network is an interest in the possibility of movement, which will allow movement to occur if social and economic conditions make it desirable; to be different, the interest in the free movement of goods must be an interest in actual movement, committing us to the belief that movement of goods across state lines is to some extent to be promoted even if social and economic conditions make it otherwise undesirable.

157. See cases cited in note 118 supra.

158. 432 U.S. 333 (1977).

159. 432 U.S. at 351. Hunt is analyzed at length in section III.A. infra. 
The notion that there might be an interest in the movement of goods as I have defined it is not totally silly. One might think that the interstate circulation of goods - the consumption in Tennessee of shoes manufactured in Maine using leather from Texas or Montana would tend to bind the union more closely together. For some years the Court of Justice of the European Economic Community appeared to be going beyond merely suppressing protectionism in its decisions about what economic regulations by member states were forbidden by the Treaty of Rome. ${ }^{160}$ The object may well have been to promote the movement of goods as such and thus to increase European interdependence, perhaps with an eye to making another intra-European war impossible or perhaps to encourage even closer political integration in the future. But there is negligible utility in promoting the free movement of goods as such in the contemporary United States. Our attempt at union has succeeded beyond the framers' wildest dreams. (Quite possibly beyond their wishes.) Interstate commerce will be vast if the courts merely suppress protectionism, and the states are tied together by much more than economic bonds. Whatever benefits in integration might be brought about by judicial supervision of state regulation going beyond the anti-protectionism principle would not be worth the extra judicial effort or the other costs.

Incidentally, if there were a national interest in the movement of goods as such, then there might be a derivative interest (again) in uniformity of commercial regulation, since uniformity would tend to promote circulation. This may partly explain the zeal of European Communitarians for harmonization, which seems surprisingly strong to an American. ${ }^{161}$ (Another explanation may be the desire to enlarge markets and achieve economies of scale.) But again, since there is no national interest in the movement of goods as such in the American context, there is no derived interest in uniform regulation.

The last item on our list, access to markets or the freedom of producers to send their goods anywhere in the country, we have already discussed in section II.A. If access to markets stands for anything more than the interest in suppressing protectionism, it must stand for the right of beer distributors to sell beer in metal cans in Oregon even though Oregon has decided such cans are pernicious. But there is no such right, and there is no national interest in recognizing any such right. Talk of access to markets might also suggest a national interest

160. See generally Schermers, The Role of the European Court of Justice in the Free Movement of Goods, in 1 CoURTS AND FREE MARKETS, supra note 1, at 222.

161. Cf. Stein \& Sandalow, On the Two Systems: an Overview, in 1 CoURTS AND FREE MARKETS, supra note 1 , at 23. 
in minimizing protectionist effect resulting from state regulation, but again, we have seen in section II.A. that there is no such interest. Protectionist effect that occurs without protectionist purpose is not a constitutional disvalue in itself.

So much for the spurious national interests suggested by the traditional rhetoric of the dormant commerce clause. A few other candidates for the status of national interests remain to be considered.

First, there is efficiency. This also we have discussed to some extent in section II.A., and we have seen that there is no hope of giving "efficiency" any significant content for constitutional purposes. When people complain that some statute causes inefficiency, they frequently mean only that it will raise the price of goods or lower production. But there is no constitutional interest in low prices or high production, either of which may have to be sacrificed in the pursuit of other values (including Pareto optimality if the low prices or high production result from uncorrected externalities). The mere fact that a statute raises prices or reduces production is not an adequate justification for judicial reexamination of the legislative decision that the statute is a good thing. ${ }^{162}$

At the other extreme of sophistication in definitions of efficiency is the idea that efficiency is Pareto optimality. But legislatures are not constitutionally required to pursue Pareto optimality. Legislatures are not even required to avoid what we might call "anti-Pareto shifts," that is, changes in the status quo that make someone worse off without making anyone at all better off. For example, there is no constitutional ban on a legislature's pursuing economic equality for its own sake, which might well require anti-Pareto shifts. (I am not, of course, recommending such a course to any legislature.)

Granted that there is no national interest in efficiency, what about something more amorphous, like a healthy economy? Now of course a healthy economy is a good thing, but it is clearly something to be pursued by legislatures; and it therefore is not a national interest of the sort we are looking for. A healthy economy is an economy that produces what we want, and the specification and ordering of social wants are legislative functions. In general, if a legislature (even a state legislature) acts to pursue some object, then that object is ipso facto something "we want" for constitutional law purposes. The inference fails only if the legislature's purpose is positively forbidden, which means, in the dormant commerce clause context, only if the purpose is protectionist.

162. Cf. Maltz, supra note 3, at 79-80. 
There is one last national interest that might be thought to require judicial protection in movement-of-goods cases, and it is, paradoxically, the interest in state autonomy - not the autonomy of the state whose law is under review, but the autonomy of other states where incidental effects are felt. If Oregon forbids metal beer cans, this will have effects in Washington (let us say) where there are firms and workers who up to now have put beer into metal cans for sale in Oregon. There are effects in Washington, but Washington has nothing to say about them. For that matter, Oregon's bottle law might cause the price of beer in metal cans to rise in Idaho if it prevents the full achievement of economies of scale in metal can distribution in the northwest market. But Idaho also has nothing to say about it.

There is a sense in which Oregon's power to produce incidental effects in Washington and Idaho does not interfere with those states' autonomy at all. Oregon has a right to speak for its own consumers (or, in a different context, for its own producers, or whatever), and the effects produced in Washington and Idaho are simply the results of market adjustment to the "virtual decision" by all Oregon consumers which the Oregon legislature has announced. We do not normally regard harm caused by market adjustment to other actors' economic decisions as an infringement of the autonomy of those who are harmed. 163

If this argument seems inadequate - if we insist that the autonomy of the State of Washington qua legislative sovereign has been diminished by the act of the State of Oregon qua legislative sovereign then the answer is that liability to such diminutions of autonomy was one of the burdens Washington accepted as part of the basic federalist compromise described in section II.C. Notice that one of the benefits Washington got in that basic federalist compromise was the power to diminish Oregon's autonomy in comparable ways. Surely both states, qua legislative sovereigns, prefer this trade of burdens and benefits (with each state's power to diminish the other's autonomy limited by

163. The argument in the text invites the following objection: If Oregon can speak for its consumers in rejecting beer in metal cans, why cannot Oregon speak for its consumers in rejecting foreign goods as such? In other words, why does not this power to "speak for" justify, say, explicit import embargoes? One possible answer is that while there is nothing objectionable in a private decision to eschew beer in cans (and therefore the state can require such decisions en masse if it chooses), there is something objectionable in a private decision to avoid foreign goods as such (and therefore the state cannot require such decisions even though we do not bother to forbid private local/foreign discrimination as long as it remains private). I am moderately content with this answer. But if the reader is not - if the reader insists that private local/foreign discrimination is totally unproblematic - I could retreat to the claim that while pure theory suggests Oregon is equally entitled to speak for its consumers on both issues (beer in cans or antiforeign prejudice), we simply cannot allow the latter sort of decision at the state level because of the much greater danger it poses to political union. 
the anti-protectionism principle, and with the supervising power of Congress in the background) to the only alternative, which is a general licensing of judicial intervention to protect nonlegislating states' "autonomy" whenever some state enacts a law with incidental out-of-state effects. So, however we look at it, the autonomy of nonlegislating states is not a national interest that deserves judicial protection in this context. ${ }^{164}$

As I said at the beginning of this section, there is no genuine national interest implicated in movement-of-goods cases that requires balancing for its vindication.

\section{F. National Interests in Transportation Cases, Taxation Cases, and Maybe Some Others}

In this section I shall discuss areas in which the Court appears to do more under the dormant commerce clause than merely suppress state protectionism. The principal areas are state regulation of the means of interstate transportation and state taxation of interstate commerce. As we shall see, the analysis leaves room for the possibility that there are other special areas as well.

Let me emphasize the very limited nature of my claims. (For the sake of concreteness, I shall speak for the moment about transportation cases, but the general idea applies to any other special areas also.) I do not mean to insist either that the Court should go beyond suppressing protectionism in the transportation area, or that it actually does go beyond suppressing protectionism. What I mean to insist on is this: First, there is much more reason to think the Court goes beyond merely suppressing protectionism in transportation cases than in movement-of-goods cases. Second, if we think the Court is doing more than just suppressing protectionism in transportation cases, there is a plausible justification for the Court's doing so that is specific to the transportation area and that does not suggest that the Court should be doing more than suppressing protectionism in movement-ofgoods cases. Third, even in the transportation area, the Court is not engaged in open-ended private interest balancing, nor in any wideranging national interest balancing. The Court is engaged in protecting one very specific national interest that is threatened when the states regulate interstate transportation.

So much for introduction. Let us consider now the transportation

164. There is, of course, a state autonomy interest (which deserves and receives judicial protection) in not being burdened by genuinely extraterritorial legislation of other states. But extraterritoriality, properly understood, is not a commerce clause concern, as I shall explain in section III.D. in the discussion of Edgar v. MITE Corp., 457 U.S. 624 (1982). 
cases, and let us start with the question of what the Court is actually doing.

The case in which a majority of the Supreme Court first endorsed a balancing approach was a transportation case, Southern Pacific Co. v. Arizona. ${ }^{165}$ Any argument that Southern Pacific was really about protectionism would be quite strained. Fourteen years later, in $B i b b v$. Navajo Freight Lines, ${ }^{166}$ the Court struck down another apparently nondiscriminatory regulation of transportation, which Justice Douglas characterized as one of the rare statutes that should be struck down despite being nondiscriminatory. 167

On the other hand, the important transportation cases of the last two decades can be seen as being just about protectionism. In Brotherhood of Locomotive Firemen v. Chicago, Rock Island \& Pacific Railroad, 168 the Court decided that Arkansas' full-crew law did not discriminate against interstate commerce and upheld the law, refusing to balance the cost to the railroads against the possible safety gain from full-crew laws. In Raymond Motor Transportation, Inc. $v$. Rice, ${ }^{169}$ a unanimous Court struck down a Wisconsin truck length regulation, ostensibly on the ground that the safety justification was totally illusory. There was much evidence in the record that the law was in fact protectionist, and there is considerable evidence in the opinions that the Court was moved by the appearance of protectionism. ${ }^{170}$ In the very similar Kassel v. Consolidated Freightways Corp., ${ }^{171}$ the plurality of four Justices repeated the theory of Raymond, while Justices Brennan and Marshall, concurring in the result, relied explicitly on the single ground that the Iowa statute under review had the impermissible purpose of diverting truck traffic to other states. ${ }^{172}$

In sum, we cannot plausibly claim that in transportation cases in the modern era the Court has been concerned only with protectionism. Southern Pacific and probably Bibb undermine that claim (though Raymond and Kassel suggest ways of reanalyzing Bibb). One might well argue that for the past twenty years the Court has been doing no more in transportation cases than suppressing protectionism, especially if the opposition to protectionism is thought to be embodied in

165. 325 U.S. 761 (1945).

166. 359 U.S. 520 (1959).

167. 359 U.S. at 529.

168. 393 U.S. 129 (1968).

169. 434 U.S. 429 (1978).

170. E.g., 434 U.S. at $446-47$.

171. 450 U.S. 662 (1981).

172. 450 U.S. at 685 (Brennan, J., concurring). 
the no-singling-out principle as opposed to the anti-protectionism principle proper. For myself, however, I am inclined to concede that the Court has been doing more than suppressing protectionism, even in the recent decades.

It is worth noting that even if the Court has been doing more than suppressing protectionism, it has probably not been balancing in the fullest possible sense. Quite possibly the effective rule for the whole of the modern era has been the rule Justice Powell states in Raymond and Kassel, namely, that the state law will be upheld unless the purported safety justification is totally illusory. Obviously this rule does not require the Court to balance in the sense of comparing costs to (nonzero) benefits. On the other hand, it still involves "balancing" in the general sense of being effects-based. It requires the Court to look at the actual consequences of the legislation, not just at what the legislature intended.

Assuming the Court is going beyond suppressing protectionism in the transportation area, there is a simple and straightforward justification: In these cases, unlike the movement-of-goods cases, there is a genuine national interest (of constitutional status) to put into the balance. Specifically, there is a national interest in the existence of an effective transportation network linking the states. Of course, the Constitution does not say that explicitly. My suggestion is that the existence of an effective transportation network is essential to genuine political union just as the suppression of protectionism is essential to genuine political union (and as economic efficiency, unlimited access to potential markets, and the actual movement of goods are not).

Let me indicate two sorts of reason for the special importance of an effective transportation network. First, from the point of view of the nation as a whole, an effective transportation system (in which I include the instrumentalities of communication) is essential to the creation and maintenance of a genuine national culture. Only if we protect the infrastructure which provides opportunities for material and intellectual exchange can we be a nation. For all our greater territorial expanse and population, we are a more unified nation now than we were in 1787; and two centuries of shared historical experience are only part of the explanation. The steamboat, the railroad, the airplane, and the television have been equally important. Second, from the point of view of the individual states, an aspect of political union is that two states should be free from barriers to their mutually desired interactions erected by a third state - barriers of the sort which could result if states were free to regulate transportation across their territories as they pleased. 
To repeat something I have said previously, I do not insist that the importance of transportation to political union justifies judicial balancing in transportation cases. There are objections to any sort of judicial balancing, and there may be special difficulties in the transportation area because of the importance of uniformity in the regulation of interstate instrumentalities like trains and trucks. Uniformity is not easy to bring about by the technique of judicial review. ${ }^{173}$ But if the Court is engaged in some sort of balancing in the transportation area, the national interest in an effective transportation network provides a plausible justification - a justification, moreover, that does not suggest balancing in movement-of-goods cases and that suggests at most a very restricted balancing, focusing on one specific national interest, in transportation cases.

Two final points regarding transportation: (1) Assuming we have decided in favor of balancing in transportation cases, then at least in theory a state law could generate a transportation case (for our purposes) even though the law on its face did not regulate transportation at all. Thus, if some state decided to dam a navigable waterway to generate electric power (and if that decision were not already subject to review under innumerable federal statutes and regulations), the effect of the state's decision on the transportation network would, if significant, give rise to a transportation case. ${ }^{174}$ (2) To the extent the Court is engaged in balancing in the transportation area, the case for a congressional power to overturn the Court's decisions is obviously even stronger than the case for a congressional power to authorize state protectionism. It is no accident that scholars sometimes express doubts about Prudential Insurance Co. v. Benjamin ${ }^{175}$ but never express doubts about Pennsylvania v. Wheeling \& Belmont Bridge Co. 176

Turning now to the taxation area, my treatment will be brief and considerably oversimplified. The Court has done much in recent years to clarify dormant commerce clause doctrine in the taxation area, but no one would claim it has completed the task of clarification. This much is clear: Although the Court is concerned to suppress protectionism in the taxation area, its concerns go beyond that. Specifically, the Court's insistence that taxes levied on interstate enterprises must

173. See Justice Rehnquist's dissent in Kassel v. Consolidated Freightways Corp., 450 U.S. 662,687 (1981).

174. For another possible example, see note 341 infra.

175. 328 U.S. 408 (1946).

176. 59 U.S. (18 How.) 421 (1856). This is of course the second Wheeling \& Belmont Bridge case, in which the Court upheld a congressional statute authorizing a bridge that the Court had previously declared an unconstitutional impediment to navigation in Pennsylvania v. Wheeling \& Belmont Bridge Co., 54 U.S. (13 How.) 518 (1852). 
be fairly apportioned cannot be explained by reference to the anti-protectionism principle or any variant of that principle. ${ }^{177}$

(Some readers might think the requirement of fair apportionment does not come from the commerce clause at all, but rather from the due process clause. ${ }^{178}$ If that were so, then possibly the Court would be doing nothing under the dormant commerce clause beyond suppressing protectionism. The Court has located the roots of the fair apportionment idea both in the commerce clause and in the due process clause. ${ }^{179}$ For myself, I think the idea is best regarded as belonging to the commerce clause alone. Congress ought to be able to overturn judicial decisions about what constitutes fair apportionment. In the present state of doctrine, such a power of Congress is more consistent with a commerce clause basis for the fair apportionment idea than with a due process basis. I shall therefore assume that the fair apportionment requirement flows from the commerce clause.)

The basis for the fair apportionment requirement is clear. The requirement is necessary to avoid a situation in which businesses that operate in more than one state are taxed more heavily, just because they operate in more than one state, than businesses operating in a single state. States are accustomed to taxing businesses in certain ways - on total capital, total revenues, total profits, and so on - that raise no problem when the business taxed operates entirely in one state, but that produce multiple taxation when the business operates in many states that tax in such a way. In order to prevent such multiple taxation, the Court has required that taxes be fairly apportioned; the states may not levy taxes on the total operations of interstate business. As in the transportation cases, to the extent the Court goes beyond suppressing protectionism it does so in the service of a particular, welldefined, national interest that we can plausibly claim is central to genuine political union. That interest is the interest in allowing interstate commerce to develop and flourish on the same terms as intrastate commerce without suffering special disadvantages merely because of its interstate character.

As it happens, the national interest just identified does not require balancing. It is adequately protected (not fully protected, but protected as fully as it is reasonable for the Court to try to protect it) ${ }^{180}$ by

177. On the fair apportionment requirement, see generally L. TRIBE, AMERICAN CoNsTITUTIONAL LAW § 6-19 (1978); Hellerstein, supra note 8, at 445-48, 451-53.

178. See, e.g., Sedler, supra note 3, at 912-13.

179. See Hellerstein, supra note 8 , at $443-44$.

180. What the Court might do, but has notably declined to do (see Moorman Mfg. Co. v. Bair, 437 U.S. 267 (1978)), is to require uniformity in fair methods of apportionment. Nonuniformity in methods that are perfectly fair considered individually can result in adventitious 
the fair apportionment rule, which does not require the Court to balance. Furthermore, this interest is not implicated in movement-ofgoods cases, and it therefore suggests no reason for the Court to go beyond suppressing protectionism in those cases.

It might seem that the interest in not subjecting interstate firms to special disadvantage just because they are interstate is implicated in movement-of-goods cases. The firm that sells in more than one state may have to comply with divergent packaging regulations; the firm that has production operations in more than one state may need to have various types of safety equipment; and so on. Are these not disadvantages that fall on interstate firms just because they are interstate? No, not in the relevant sense. It is true that the firm could avoid these disadvantages by confining its operations to one state. Even so, the disadvantages do not arise just because the firm is interstate. They arise because the states the firm operates in have divergent substantive views about packaging, or safety, or whatever. The existence of such diversity can hardly be thought to create a constitutional problem. As I have argued previously, uniformity of commercial regulation is not a constitutional value.

There is a deep difference between the problem of divergent substantive regulations and the problem of unapportioned taxes. The problem created by divergent substantive regulations is a problem of uniformity or the lack of it. The problem of unapportioned taxes is not. If all states had the same packaging regulations, for example, then whatever special problems packaging regulations create for firms that operate across state lines would disappear. That shows there is nothing intrinsically problematic in any particular packaging regulation (and if different states happen to prefer different regulations, well, they're entitled). The problem of unapportioned taxes, in contrast, would not be solved by persuading all states to enact the same unapportioned tax. Perfect uniformity in unapportioned tax laws would still leave interstate firms facing a special disadvantage just because of their interstate organization. So there is something specially objectionable in each and every unapportioned tax. The unapportioned tax is a special problem, implicating a special national interest and justifying a special solution.

The national interest in not subjecting interstate commerce to special disadvantage just because of its interstate character may account for some other hard-to-classify doctrines in addition to the Court's fair

burdening of interstate commerce. But this the Court has quite reasonably decided not to worry about. Compare the remarks in the text immediately following this note on uniformity in a different context. 
apportionment rule. For example, this interest may account for the rule of Freeman v. Hewit ${ }^{181}$ that an interstate sale may not be taxed by the state of the seller. The Court had already effectively decided that such sales could be taxed by the state of the buyer. So prohibiting taxation by the seller state was a way of preventing cumulating taxes. ${ }^{182}$ Also in the tax area, this same national interest can explain the unconstitutionality of flat-rate license taxes on door-to-door salesmen. ${ }^{183}$ Such flat-rate taxes, if adopted by many cities and states, bear much more heavily in the aggregate on a firm that sells in many places than on a firm otherwise identical (and in particular, with the same total quantity of sales) that sells in only one place. To prevent disadvantaging operations that straddle political boundaries, we ban such flat-rate taxes.

Outside the tax area, the national interest in not disadvantaging interstate commerce as such provides the best dormant commerce clause explanation of a case like Allenberg Cotton Co. v. Pittman. ${ }^{184}$ (The ensuing discussion of Allenberg may seem, if not strictly digressive, then disproportionately long in the present context. But if I did not discuss Allenberg fully here, I would have to do so in section III.D.) Allenberg was a Tennessee firm that bought some cotton in Mississippi through an independent Mississippi cotton broker, temporarily stored the cotton in a Mississippi warehouse that it did not own, and then shipped the cotton interstate to its customers. When Allenberg tried to sue a Mississippi seller of cotton in a Mississippi court, it was denied access to the court on the ground that it had not qualified to do business in Mississippi. In a brief and unenlightening opinion by Justice Douglas, the Supreme Court held that Mississippi could not deny Allenberg access to its courts; Allenberg's connections with Mississippi lacked the "sort of localization or intrastate character" that was necessary for Mississippi to be able to subject Allenberg to its qualification requirements. ${ }^{185}$

Douglas purported to rely on the dormant commerce clause, but he did not explain how that clause generated the result. Plainly, the case does not turn on discrimination by Mississippi. The burdens of qualification imposed on foreign firms were not greater than other bur-

181. 329 U.S. 249 (1946).

182. See T. Powell, Vagaries and Varieties in Constitutional INTERPRetation 190 (1967).

183. See Nippert v. City of Richmond, 327 U.S. 416 (1946).

184. 419 U.S. 20 (1974).

185. 419 U.S. at 33. 
dens placed on domestic firms. ${ }^{186}$

To my mind, it seems best to regard Allenberg not as a commerce clause case but as one of the many doctrinal orphans created by the much-evaded rule that the article IV privileges and immunities clause does not apply to corporations. After all, would the proper result be different if Allenberg had engaged in no commerce in Mississippi but had been refused access to the Mississippi court when it tried to sue to establish title to a parcel of land someone had given it?

Still, if we must take Douglas' claim to rely on the commerce clause at face value, we can notice that a proliferation of qualificationto-do-business requirements applied to firms with minimal local contacts could have the effect (like the flat-rate drummer's tax or the unapportioned tax on some aspect of business operations) of disadvantaging interstate commerce just because such commerce straddles political boundaries. This is the best commerce clause explanation of Allenberg. ${ }^{187}$

Notice that with the drummer's tax and the qualification-to-dobusiness requirement, as with the unapportioned tax on gross revenue or whatever, uniformity or lack of it in the laws of different states is not the issue. A proliferation of perfectly uniform drummer's taxes and qualification requirements would still disadvantage interstate commerce as such.

So much for the transportation and taxation areas and the national interests to which they lead us. In the title of this section I referred to national interests in "transportation cases, taxation cases, and maybe some others." I certainly want to hold open the possibility that there are some others, though there may not be. I do not think there are any national interests besides those $I$ have discussed that are recognized in the cases, but there is nothing to prevent us from recognizing hitherto unnoticed national interests in response to new sorts of state legislation.

Vincent Blasi has posed a hypothetical that puzzled me for years. ${ }^{188}$ Blasi asks what the Supreme Court would do if some state were to enact a general price stabilization law setting maximum prices

186. Sedler, supra note 3, at $905 \mathrm{n.76}$, appears to suggest that Allenberg is a discrimination case - that Mississippi is discriminating against Allenberg by imposing on it, a foreign firm, an unconstitutional prerequisite to suit while no unconstitutional prerequisite is imposed on local firms. But this analysis begs the real question in issue: Why is the prerequisite that is imposed on Allenberg unconstitutional in the first place?

187. L. TRIBE, supra note 177 , at $344 \mathrm{n} .12$, mentions this explanation of Allenberg, though he gives greater prominence to another proposed explanation, that the Court was trying to protect the national futures market in cotton. Id. at 343-44.

188. Blasi, supra note 1 , at 191 . 
for a wide range of goods - not as a response to a problem in some particular industry or market, but as a general anti-inflationary measure. Blasi does not say the Court would strike down such a law, but he suggests that it might and that its doing so would not seem clearly at odds with established doctrine. If Blasi is right about that - and I am prepared to concede for purposes of argument that he is - then we seem to have a counterexample to my claim that the Court is concerned only with suppressing protectionism in movement-of-goods cases. (This case would be a movement-of-goods case since it does not involve transportation, taxation, or the state as market participant.) The price stabilization law is not protectionist. It need not be just an attempt to make firms charge their overhead to consumers in other states - the state legislature might be happy to see the law enacted everywhere. But it still might be struck down.

Here is the answer to Blasi's puzzle: if the state law were struck down, it would show that the Court had recognized a national interest (with constitutional status) in a uniform national monetary policy. As with the other genuine national interests we have considered, this interest would be implicated only in a limited class of cases. It suggests no interest in uniformity of commercial regulation in general; and it would have no bearing on most commerce clause cases. (Incidentally, it is not even clear that we would need to allocate a judicial decision based on the interest in uniform monetary policy to the commerce clause. There are other clauses of the Constitution that suggest such an interest quite directly - clauses that give Congress the power to coin money and to regulate its value, ${ }^{189}$ and that forbid the states to coin money, emit bills of credit, or make anything but gold and silver coin legal tender. ${ }^{190}$ )

If we recognize a commerce clause-based national interest in uniform monetary policy (or, for that matter, if we treat Allenberg as a commerce clause case implicating the national interest in not disadvantaging interstate commerce just because it is interstate), then in order to preserve my claim that in movement-of-goods cases the Court is concerned only with suppressing protectionism, we must expand the list of exclusions by which movement-of-goods cases are defined. Specifically, we must stipulate that cases involving state laws setting monetary policy (or involving state laws other than tax laws that tend to disadvantage interstate commerce as such) are not movement-of-goods

189. U.S. CoNST. art. I, § 8, cl. 5.

190. U.S. CONST. art. I, $\S 10$, cl. 1 . 
cases, just as transportation cases and taxation cases already are not movement-of-goods cases.

In fact what we really want to say, given the potential open-endedness of the list of genuine national interests, is that movement-of-goods cases are just those cases in which no national interest other than the anti-protectionism interest is implicated. (The state-as-market-participant cases continue as a special, separate exclusion.) At that point, the claim that in movement-of-goods cases the Court is concerned only to suppress protectionism is nearly tautological. (The claim is not entirely tautological, since it still excludes the possibility of private interest balancing.) But even to the extent it has become tautological, the claim remains an interesting tautology; it reminds us that national interests ought to be specifically identified and that many of the supposed national interests suggested by standard commerce clause rhetoric are impostors.

As to other possible national interests, two further possibilities (or perhaps one further possibility and a conjectural subspecies of it) deserve mention. Ernest Brown has suggested that there is a national interest in seeing that states do not unreasonably exploit their geographic position. ${ }^{191}$ The reference to exploitation suggests purposebased review under the no-hostile-treatment principle; but it seems to be balancing that Brown really has in mind. ${ }^{192}$ This interest (among others) is protected with regard to international commerce by the import/export clause. ${ }^{193}$ Brown points out that the interest may be implicated also when states regulate interstate commerce, for example, by taxing transportation through their territory. Brown concludes that the Court must stand ready to review for reasonableness even nondiscriminatory taxes on transportation.

Assuming Brown is right about this, his particular conclusion is already covered in our analysis by the national interest we have recognized in an effective transportation system. The interest in an effective transportation system is broader than Brown's interest, since some threats to transportation are not exploitations of geographic position in any natural sense. On the other hand, our interest does seem to include Brown's; it is hard to see what besides an imposition on transportation (in some form) could count as an exploitation of position. For Brown, the example about exploiting position by taxing transportation is the centerpiece of an argument for balancing in all sorts of

191. Brown, supra note 1 , at 228-33.

192. Compare the references to judicial identification and evaluation of "interests," $i d$. at 228, 234.

193. U.S. CONST. art. I, $\S 10$, cl. 2. 
commerce clause cases. But in extending his conclusion to cases other than transportation and taxation cases, ${ }^{194}$ Brown overgeneralizes and reveals a preference for laissez-faire that has no constitutional grounding.

I mentioned a "conjectural subspecies" of the interest in preventing exploitation of geographic position. Someone might suggest that states have their various natural resources (like Montana's coal) by virtue of geographic position, and that in order to prevent exploitation of position the Court should insist that out-of-staters be granted access to these resources on reasonable (as opposed to merely nondiscriminatory) terms. The Court has not taken this view, ${ }^{195}$ nor should it. The Court has decided in effect that access for out-of-staters on nondiscriminatory terms is essential to political union, at least when the issue arises in an economic context. ${ }^{196}$ But access to resources on terms that, in addition to being nondiscriminatory, are judicially certified as reasonable is not necessary to union. Uniform national policy with regard to resource use is no more a constitutional value than is uniform commercial regulation in general. 197

In the course of this section, a definite theme has emerged. I shall state it and be done. Genuine national interests for dormant commerce clause purposes are those interests, and only those, that, like the interest in preventing state protectionism, are fundamentally related to the existence and political viability of federal union. The interest in an effective transportation network, the interest in protecting interstate commerce from special disadvantage that flows just from its being organized across state lines, and perhaps the interest in a uniform national monetary policy, are such interests. No others that might be thought of as falling under the dormant commerce clause come to mind.

194. That is, in his discussion of Baldwin v. G.A.F. Seelig, Inc., 294 U.S. 511 (1935), and Henneford v. Silas Mason Co., 300 U.S. 577 (1937). Brown, supra note 1, at 233-36. Baldwin does not involve transportation or taxation in any sense; Henneford involves a tax, but it does not involve the national interest in avoiding multiple taxation which makes tax cases special. I discuss Baldwin and Henneford in section III.C. infra.

195. See Commonwealth Edison Co. v. Montana, 453 U.S. 609 (1981); Cities Serv. Gas Co. v. Peerless Oil \& Gas Co., 340 U.S. 179 (1950).

196. The restriction to an economic context is suggested by Baldwin v. Fish \& Game Commn., 436 U.S. 371 (1978).

197. As Justice Marshall says in Commonwealth Edison Co. v. Montana, 453 U.S. 609,619 (1981): "We are not convinced that the Commerce Clause, of its own force, gives the residents of one State the right to control in this fashion the terms of resource development and depletion in a sister State." 


\section{G. The State as Market Participant and Related Matters}

At last we come to the exceptional case of the state as market participant and, more broadly, to the explication of the second half of our definition of protectionism. The second half of the definition, remember, made it a necessary condition for a statute (or administrative order, or whatever) to count as protectionist that, in addition to having a protectionist purpose, it be "analogous in form to the traditional instruments of protectionism [such as the tariff]." We shall now see what laws are not analogous in form to the traditional instruments of protectionism and why those laws deserve special treatment.

There is no doubt that a state can favor its own citizens in certain contexts. Alaska can limit the distribution of its oil royalties to its own citizens, as it can limit the payment of welfare benefits from the state treasury. (In the present context, where we are worrying about discrimination against people or entities belonging to other states and not about discrimination against aliens, I shall simply include aliens resident in Alaska within the reference of "citizens" of Alaska to the extent the Supreme Court has held that resident aliens must be treated like citizens.)

The state can go further. There are ways in which it can favor its own citizens even in the pursuit of a protectionist purpose. (There is no protectionist purpose in the discriminatory distribution of oil royalties or welfare benefits, since citizens and welfare recipients do not compete as such with their foreign counterparts.) For example, the state can purchase goods and services only from local providers. ${ }^{198}$ The state can advertise on television on behalf of the state's tourist industry. The state can waive property taxes on new manufacturing plants, thereby securing jobs for local workers at the expense of foreign. The state can operate an agricultural extension service that provides advice only to local farmers. Under White v. Massachusetts Council of Construction Employers, 199 the state can require private contractors to give a hiring preference to local workers in connection with state-funded construction.

There is an obvious feature that is common to all these instances of permissible discrimination in favor of locals: The state is spending money. (The property tax waiver I am regarding as a "tax expenditure." Whatever we think of that concept in general, there can be no doubt that the tax waiver is different in its direct fiscal effect from an

198. American Yearbook Co. v. Askew, 409 U.S. 904 (1972) (mem.), affg. 339 F. Supp. 719 (M.D. Fla. 1972).

199. 460 U.S. 204 (1983). 
ordinary regulation or from a tariff, which generates revenue.) So, as a first approximation to what we mean by the "analogous in form" requirement in the second half of the definition of protectionism, we might consider this: a discriminatory law is not analogous in form to the traditional instruments of protectionism if the discrimination consists solely in channeling to locals benefits purchased with (or simply consisting of) state funds.

Now, why should it matter under the dormant commerce clause whether the discriminatory state law involves spending as opposed to mere regulation or the positive imposition of a tax? Here are some possible reasons:

(1) For the most part, state spending programs are less coercive than regulatory programs or taxes with similar purposes. If a state's advertising for the local tourist industry seduces away tourists from neighboring states, at least no tourist has been forced to patronize the local attractions. If a tax waiver induces a manufacturer to locate instate, he has never been forced to prefer local workers. Because spending programs are less coercive, they seem to interfere less, or less objectionably, with the ordinary workings of the market economy.

(2) Partly because they are less coercive, and partly because it just seems obvious that when states distribute benefits they can prefer their own citizens, discriminatory spending programs seem less hostile to other states and less inconsistent with the concept of union than discriminatory regulation or taxation.

(3) Many spending programs are positively beneficial from the point of view of the nation as a whole - agricultural extension services, advertising (to the extent it has information content), certainly welfare programs. But many of these programs would not exist if the state could not channel the primary benefits to locals. Even the construction involved in White v. Massachusetts Council of Construction Employers, to the extent it was a public works program, created an unquestioned benefit and probably would not have existed if the local preference aspect had been forbidden.

(4) The very fact that spending programs involve spending and are therefore relatively expensive as a way of securing local benefit makes them less likely to proliferate than measures like tariffs. They are therefore less likely to damage the economy seriously in the aggregate, -if they damage it at all.

(5) Because spending programs are perceived as less hostile to other states than tariffs and the like, they are less likely to produce resentment and retaliation. Also, because the only permitted retaliation would be in the form of spending, the expensiveness of retaliation 
is itself a deterrent. And even if retaliation occurs, the combined effect of spending and retaliatory spending (for example, on advertising) will often be to cancel out or to create a small net benefit (in this case, of information dissemination). The original program and the retaliatory response will often not cumulate as tariffs and retaliatory tariffs do in their tendency to partition the economy.

Now, not all of these reasons for the permissibility of discrimination in spending programs are relevant to all the examples of permissible discrimination that I listed above; but each of the examples receives support from some of the reasons. I shall not pause to analyze each of the examples individually. I eschew fine-grained analysis partly in the interest of brevity and partly because there is an excellent analysis of discriminatory spending by a state, under both the commerce clause and the privileges and immunities clause, in an article by Jonathan Varat. ${ }^{200}$ I do not agree with all the details of Varat's analysis; but I agree with quite enough to render superfluous a detailed analysis of my own.

To give just a little more substance to my catalogue of reasons why spending is special, let me explain why Reeves, Inc. v. Stake, ${ }^{201}$ which divided the Supreme Court five to four (as dormant commerce clause cases rarely do), is a genuinely difficult case. In Reeves the Court upheld South Dakota's policy of preferring South Dakota buyers in selling the output of a state-owned cement plant. There should be no doubt that a state can build and operate a cement plant and can choose to sell the output of the plant only to local purchasers - at least provided the policy of local preference is pursued consistently from the founding of the plant. But South Dakota did not pursue its local preference policy consistently. By selling cement to foreign users when cement was plentiful, South Dakota both invited foreigners to rely on its cement production and quite possibly prevented the emergence of private suppliers for the foreign demand it was supplying. Obviously the usual state-created benefit scheme that limits the benefit to locals neither encourages foreign reliance nor displaces private suppliers for the foreign demand. For the state that has encouraged reliance and displaced alternative suppliers (even unintentionally) now to discriminate against foreigners seems much more hostile than the normal scheme involving state spending for locals.

Furthermore, the current benefit that is distributed on a discriminatory basis may seem to cost the state essentially nothing. The oper-

200. Varat, supra note 82, at 487.

201. 447 U.S. 429 (1980). 
ating costs of the plant are presumably covered by the selling price of the cement, which foreigners are eager to pay but are not allowed to. The state's original investment in the plant has probably been long since recouped, in part from foreign purchasers of cement during the years when the plant sold to all comers. If we think it important that the benefits that are limited to locals be expensive for the state (and I tend to think this is quite important), then South Dakota's behavior is very troublesome indeed. For myself, I probably would have decided Reeves, Inc. v. Stake differently than the Court; that is, I probably would have invalidated South Dakota's local preference. But in any event, it is a difficult case.

If I am right that the expensiveness to the state of the benefit being distributed should matter, then I have another theoretical bone to pick with the Court, though one that may matter little in practice. The Court can be taken to suggest that a straightforward production subsidy for local producers is constitutionally permissible. ${ }^{202}$ This is troublesome. A carefully calibrated subsidy that was passed on to consumers in a relatively competitive market could achieve a substantial redirection of business to local producers at very little cost. The state might get so much market distortion for its subsidy dollar that the expense of providing this benefit to locals would not be an effective constraint. In principle, I think such direct subsidies should probably be forbidden. On the other hand, such direct subsidies are rare in practice. (I am tempted to say they do not exist, in our context, but such statements are dangerous and certainly would require more precise definition.) The explanation that springs to mind is this: the informational demands for designing the dangerously cost-effective subsidy are just too great; states cannot ordinarily design just the right subsidies in just the right markets. If that is why there are so few direct subsidies, then there may be no practical problem, but the Court should stand ready to reconsider what it has said about direct subsidies if and when states actually start using them. ${ }^{203}$

The approach I have suggested to Reeves, Inc. v. Stake and to subsidies would substantially increase the difficulty of case-by-case adjudication. That suggests that perhaps we should just have a flat rule:

202. The seeming permissibility of straightforward production subsidies results from the Court's not squarely relying, in Hughes v. Alexandria Scrap Corp., 426 U.S. 794 (1976), on the claim that the commerce affected by the state's bounty scheme was "created" by the state. 426 U.S. at 809 n. 18 .

203. The result in Hughes v. Alexandria Scrap Corp. itself is almost certainly correct, both on the ground that the bounty scheme did create the relevant commerce (cf. note 202 supra) and on the ground that Maryland had no purpose to give local scrap processors a competitive advantage. Maryland's purpose was simply to make it more likely that the hulks it procured the processing of came from Maryland. 
anything that is plausibly characterizable as a spending program escapes the commerce clause prohibition on local preference. But it is doubtful we could live with all the consequences of this rule, even if we were prepared to accept its validation of direct subsidies and South Dakota's behavior in Reeves, Inc. v. Stake. Suppose, for example, that in the basic situation of White v. Massachusetts Council of Construction Employers, the City of Boston had required of contractors for public construction projects that they give a hiring preference to locals even on some number of privately funded projects? That requirement would be part of a spending program, but it would be very hard to swallow. ${ }^{204}$ If we attempt to forbid that requirement by saying the state may not require private parties to discriminate in their dealings with other private parties, ${ }^{205}$ then we apparently forbid the hiring preference requirement upheld in White itself, since construction workers are private parties. But White seems correctly decided.

It looks like we are going to have to do some line-drawing somewhere. For myself, I would wade in and attempt to decide what should count as a spending program (or what requirements on participants should count as sufficiently closely related to the spending aspect . of the program) in light of the reasons I have given for regarding spending programs as special.

Notice that this line drawing, though it is a different sort of exercise from the inquiry into purpose which settles ordinary movementof-goods cases, still involves no balancing. The applicability to a particular state program of the various reasons for the spending exception can ordinarily be decided just by looking at the general structure of the program, without worrying about precise effects. On occasion we may find ourselves "balancing" structural reasons for regarding something as a spending program against other structural reasons for not so regarding it, but that is not at all the same thing as evaluating and balancing social costs and benefits. Even where we may have to give some thought to the program's effects (for example, if we take seriously the idea that a spending program should involve significant expense relative to the possible magnitude of market distortion benefits), we are not engaged in evaluating and comparing local benefits and out-of-state or national burdens. The inquiry is more focused and

204. The Court has rejected analogous far-reaching conditions attached to dealings with the state in Hicklin v. Orbeck, 437 U.S. 518 (1978) (decided under the privileges and immunities clause), and South-Central Timber Dev., Inc. v. Wunnicke, 467 U.S. 82 (1984) (plurality opinion of White, J.).

205. This suggestion is considered in Smith, supra note 3 . 
more concerned with the structure of the program itself than is any wide-ranging balancing inquiry.

I shall not claim that the Court is following my approach in the state-as-market-participant area, though the results of the few decided cases would certainly be consistent with the claim that the Court is feeling its way towards a position like mine. At this point it is clear that the Court as a body has no consistent theoretical position at all. Consider: The first major case was Hughes v. Alexandria Scrap Corp., ${ }^{206}$ in which the Court upheld a Maryland law making it easier for local scrap-processors than for foreign scrap-processors to secure a bounty paid by Maryland on the processing of Maryland-titled automobile hulks. The opinion of the Court was written by Justice Powell; Justice Stevens wrote a supplementary concurring opinion. In Reeves, Inc. v. Stake, ${ }^{207}$ a five-to-four decision, Justice Blackmun wrote the majority opinion and treated Reeves as a straightforward application of the principle of Hughes. Powell and Stevens both dissented. In White v. Massachusetts Council of Construction Employers, ${ }^{208}$ decided by a seven-to-two margin (on the basic commerce clause issue), Justice Rehnquist, writing for the majority, regarded the case as directly controlled by a proposition common to Hughes and Reeves. Blackmun wrote the dissent. The latest case is South-Central Timber Development, Inc. v. Wunnicke, ${ }^{209}$ which involved an Alaska requirement that purchasers of state-owned timber partially process the timber within Alaska before exporting it. Strictly speaking, the Court as a whole decided nothing at all about the state-as-market-participant aspects of Wunnicke; but there was a plurality opinion disapproving the Alaska scheme written by Justice White, who dissented in Hughes, Reeves, and White. Rehnquist, who had just written for the Court in White, dissented in Wunnicke. So far, in short, whoever writes for the majority in one case can be counted on to dissent in the next. If there is a common theory developing here, it is still in a formative stage..$^{210}$

206. 426 U.S. 794 (1976).

207. 447 U.S. 429 (1980).

208. 460 U.S. 204 (1983).

209. 467 U.S. 82 (1984).

210. There is one later case worth mentioning; the case involves the state-as-market-participant doctrine but does not involve the central problem of definition. Wisconsin Dept. of Indus., Labor \& Human Relations v. Gould, 106 S. Ct. 1057 (1986). In Gould the Court, unanimous at last, decided that the state-as-market-participant doctrine did not extend to allowing Wisconsin to "enforce" the National Labor Relations Act by refusing to make purchases from three-time violators of the Act. The Act's enforcement provisions were held to preempt supplementary state enforcement mechanisms, even mechanisms using the state's purchasing power. Gould is correct. The fact that the nondiscrimination principle embodied in the dormant commerce clause has a greatly reduced application when the state is spending its own resources does not imply that the state can spend as it pleases, in contravention of valid federal statutes. Incidentally, 
I should say that to my mind Wunnicke, like Reeves, is a hard case. It is no disgrace to the Court to be split by it. Wunnicke calls for just the sort of line-drawing that I said was unavoidable a couple of paragraphs back. For myself, I would probably come out the same way the plurality did. (Of course, when I say Wunnicke is a hard case, I mean on the state-as-market-participant issue. Once it is decided that the state has gone beyond what that doctrine allows, Wunnicke is an easy case, as White says, ${ }^{211}$ on the issue of whether the export embargo on unprocessed logs violates the commerce clause. ${ }^{212}$ )

We should also take note of United Building \& Construction Trades Council v. Mayor of Camden. ${ }^{213}$ Camden was not a commerce clause case at all. On its facts, it was essentially identical to White $v$. Massachusetts Council of Construction Employers, but it was litigated under the privileges and immunities clause. It is easy to read Camden superficially and to conclude that Camden effectively overrules White by holding that the state-as-market-participant idea is irrelevant under the privileges and immunities clause, which therefore condemns the local-hiring requirement. That seems paradoxical. The air of paradox is increased by the fact that even though Camden seems effectively to overrule White, the opinion of the Court is written by the same person as in White (Rehnquist) and the dissent is written by the same person as in White (Blackmun). Happily, things are not quite as confused as they look. Blackmun's Camden dissent turns on an issue that had not previously been important in this line of cases, namely, the significance of discrimination by city lines instead of state lines. ${ }^{214}$ More important, the Court does not really hold in Camden that the state-as-market-participant idea is irrelevant to the privileges and immunities clause. Let me explain.

For one thing, with regard to the result in the case, the Court does not invalidate the Camden ordinance; it merely remands the case for further consideration. If anything, the Court seems to lean more towards upholding the ordinance than towards invalidating it. The Court also makes it clear that the sort of considerations that $I$ have suggested underlie the state-as-market-participant doctrine under the commerce clause are relevant on remand under the privileges and im-

Gould reveals that the state-as-market-participant doctrine is not aptly regarded as a doctrine about "state sovereignty".

211. 467 U.S. at 99 (opinion of White, J.).

212. Cf. the extended discussion of Pike v. Bruce Church, Inc., 397 U.S. 137 (1970), in section III.A. infra.

213. 465 U.S. 208 (1984).

214. For my view on city-line discrimination, see the discussion of Dean Milk Co. v. City of Madison, 340 U.S. 349 (1951), in section III.A. infra. 
munities clause. ${ }^{215}$

Aside from the result, when the Court says that the state-as-market-participant doctrine does not apply to privileges and immunities cases in exactly the same way as to commerce clause cases, ${ }^{216}$ that actually makes sense - not for the reason the Court gives, but for two other reasons. First, remember that the person speaking for the Court is Rehnquist; and Rehnquist's mechanical approach to the state-asmarket-participant doctrine, which allows a state to impose on parties with whom it has contractual dealings any conditions it has the market power to secure, ${ }^{217}$ is not really appropriate anywhere, not even under the commerce clause. Any avenue of retreat from this position has something to recommend it. Second, from the point of view of ideal doctrine, there are some benefits which the state should not be able to reserve for its own citizens even though the state provides them at substantial expense. Examples of these benefits are roads and courts. The privileges and immunities clause is a historically apt ground for limiting the state-as-market-participant idea (which we have seen is fundamentally a state-as-distributor-of-state-purchasedbenefits idea) where such special benefits are in question. ${ }^{218}$

There is one last type of case to discuss briefly in this section which superficially has no connection at all with the matter of the state as market participant. Imagine that a state's cantaloupe growers have been packing cantaloupes deceptively, putting good fruit in the visible top layers of a crate and hiding bad fruit inside. This practice, which even honestly disposed growers are forced into because of their local competitors' behavior, is giving the state's cantaloupe a bad reputation in both local and out-of-state markets. In order to improve the local fruit's reputation, the state adopts a statute and an administrative scheme to stop deceptive packaging. Notice it is perfectly possible, and $I$ mean to assume in this hypothetical, that the state cares not at all for the interests of deceived cantaloupe purchasers, local or foreign, as such. The point of the quality control scheme is just to help local growers by protecting the local fruit's reputation. (Notice also that this case is not Pike v. Bruce Church, Inc., ${ }^{219}$ though I have made it

215. 465 U.S. at $221-23$.

216. 465 U.S. at $219-220$.

217. See Rehnquist's dissent in South-Central Timber Dev., Inc. v. Wunnicke, 467 U.S. 82, 101 (1984).

218. Cf. Maltz, supra note 3, at 71-72. Incidentally, although the privileges and immunities clause seems the historically right source for this limitation, we cannot rely on the privileges and immunities clause exclusively for the limitation so long as we are saddled with the doctrine that the privileges and immunities clause does not protect corporations.

219. 397 U.S. 137 (1970). 
similar to Pike so that I can refer to it when I discuss Pike in Part III.)

Now, the scheme I have described would not strike anyone as subject to serious challenge under the dormant commerce clause. Nor should it. But the scheme does have a protectionist purpose, a purpose to improve the competitive position of local cantaloupe growers vis-àvis their foreign competitors. The scheme does not count as protectionist because of the second half of our definition of protectionism. The scheme is not analogous in form to the traditional instruments of protectionism.

So, the second half of the definition of protectionism is relevant to more than just the state as market participant. Indeed, there are likely to be many laws like the cantaloupe quality control scheme once we start looking for them. Despite the obvious differences, there is an analogy between the state-as-market-participant cases and the state-asimposer-of-competitively-motivated-standards cases. It is not an accident that these two sorts of cases fall under one "exception" in our definition of protectionism. When the state imposes standards for competitive reasons, it is interfering in the market with no purpose but to improve local competitors' prospects. But no one is coerced except those whose advantage is being sought; there is in all likelihood a benefit from the program to some foreign parties (cantaloupe purchasers); and the advantage to local producers is bought at significant direct local expense, not in the form of money from the state treasury, but in the form of higher costs and changed behavior from the local cantaloupe growers themselves.

I said in the Introduction (I.B.) that all the state laws involved in what the reader would think of as standard dormant commerce clause cases are sufficiently analogous in form to the traditional instruments of protectionism so that they count as protectionist if they have a protectionist purpose. I shall not argue specifically for this claim; I hope it is clear intuitively in light of the discussion of this section. We have seen that there are some regulatory schemes like the cantaloupe quality control scheme that, despite protectionist purpose, escape condemnation because of the second half of the definition of protectionism. But schemes of the sort we normally worry about - the labeling restrictions of Hunt v. Washington State Apple Advertising Commission, ${ }^{220}$ the laws at issue in Exxon Corp. v. Maryland ${ }^{221}$ and Minnesota v. Clover Leaf Creamery Co. ${ }^{222}$ (if they are considered as possibly hav-

220. 432 U.S. 333 (1977).

221. 437 U.S. 117 (1978).

222. 449 U.S. 456 (1981). 
ing bad purpose), the laws in City of Philadelphia $v$. New Jersey ${ }^{223}$ or Great Atlantic \& Pacific Tea Co. v. Cottrell, ${ }^{224}$ the law in Baldwin v. G.A.F. Seelig, Inc. ${ }^{225}$ and the administrative order in H.P. Hood \& Sons v. Du Mond ${ }^{226}$ — all of these are obviously sufficiently analogous in form to tariffs, embargoes, or quotas to be impermissible if they were adopted with bad purpose. We can see this directly by seeing that these laws impose coercive barriers to trade in a way the cantaloupe packing law does not; or we can see it by reflecting that the reasons for allowing the spending exception and the quasi-spending exception that covers the cantaloupe packing law apply to these traditionally problematic laws either weakly or not at all.

\section{H. The Anti-Protectionism Principle and the Privileges and Immunities Clause}

Recently both Charles Black and Julian Eule have suggested that perhaps the anti-discrimination idea which we now locate in the dormant commerce clause should be located instead in the privileges and immunities clause of article IV.227 The dormant commerce clause could then be dispensed with entirely.

Now, I am inclined to reject this doctrinal reconstruction, for ream sons I shall sketch presently; but I am not vehemently opposed. Since my argument for the anti-protectionism principle (in whatever variation we adopt it) is primarily structural, I am not overly concerned with what textual hook we hang the principle on. The truth is, I think it can be a mistake to insist too strongly on identifying a particular textual hook. Associating a structural idea with any particular bit of text may have incidental doctrinal consequences, because of other uses that have been made of the same bit of text, that we do not want. Also, the fact that the dormant commerce clause and the privileges and immunities clause are both prohibitions on discrimination against foreigners does not mean they have or should have the same scope. It may be useful to keep more than one anti-discrimination weapon in our arsenal, with different weapons for different tactical purposes.

Turning to specifics: There are significant doctrinal hurdles in the present state of privileges and immunities doctrine that must be got over before the privileges and immunities clause can subsume the dormant commerce clause. At present, the privileges and immunities

223. 437 U.S. 617 (1978).

224. 424 U.S. 366 (1976).

225. 294 U.S. 511 (1935).

226. 336 U.S. 525 (1949).

227. Black, supra note 3, at 65; Eule, supra note 12, at 446-55. 
clause does not protect corporations, and it protects only "fundamental" rights. ${ }^{228}$ The first of these doctrines, that the privileges and immunities clause does not protect corporations, ought to be abolished, but the Court has been reluctant to abolish it officially. As to the doctrine that privileges and immunities include only fundamental rights, I am not certain that doctrine should be abolished. For example, I have some inclination to think Baldwin v. Fish \& Game Commission ${ }^{229}$ was rightly decided - not just because of any state spending on wildlife management, but because Montanans may be entitled to benefit specially from a state policy of general nondevelopment that they specially bear the opportunity costs of. In any event, I doubt that I should have to make up my mind about Baldwin v. Fish \& Game Commission in order to be sure what I may think about Baldwin v. G.A.F. Seelig, Inc. ${ }^{230}$ Nor can we solve this problem by just asserting that all rights to engage in any kind of economic activity are fundamental. The right to seek a job may be fundamental;231 but not the right to buy space in a landfill, ${ }^{232}$ at least not if "fundamental" means anything at all. In truth, we probably believe that "fundamental" should not mean anything at all in the economic sphere - that is to say, we probably do not think any requirement of "fundamentality" should limit our economic anti-discrimination principle. But that just means we have reason to keep our economic anti-discrimination principle distinct from our noneconomic one. ${ }^{233}$

Black and Eule are aware of these doctrinal hurdles, and presumably they are either able to jump them or willing to knock them down. Waiving these issues, there is a different and serious textual obstacle to

228. Baldwin v. Fish \& Game Commn., 436 U.S. 371, 387-88 (1978) (on fundamental rights approach).

229. 436 U.S. 371 (1978).

230. 294 U.S. 511 (1935).

231. Cf. Supreme Court v. Piper, 470 U.S. 274 (1985); Hicklin v. Orbeck, 437 U.S. 518 (1978).

232. Cf. City of Philadelphia v. New Jersey, 437 U.S. 617 (1978).

233. Not only is there a difference between our economic anti-discrimination principle and our noneconomic anti-discrimination principle that may be captured by the "fundamental rights" idea, there is another distinction that may be captured by that idea that is important to the scope of a limitation on the general anti-discrimination theme. As we saw in section II.G., we are willing to countenance discrimination by the state with regard to benefits the state creates (roughly); except that some state-created benefits, such as roads and courts, are so fundamental that as to them the state may not discriminate even though it is paying the bill. Needless to say, ensuring nondiscrimination with regard to roads and courts is right at the center of the historical purposes of the privileges and immunities clause. I shall not analyze either application of the fundamental/nonfundamental distinction in detail; nor do I necessarily claim that we would spell out the distinction exactly the same way for each application considered separately. My point is simply that doctrinal resources should not be thoughtlessly abandoned. They should be husbanded and, if possible, put to good use. 
Black's and Eule's approach. The privileges and immunities clause says that the citizens of each state shall be entitled to all privileges and immunities of citizens "in the several states." 234 (The emphasis is mine.) Consider now a central commerce clause case such as Pike $v$. Bruce Church, Inc. ${ }^{235}$ Does Arizona's ban on the export of unpacked cantaloupes violate the privileges and immunities clause? It hardly seems that it can, if we take the text seriously. Bruce Church was free to do anything in Arizona that anyone else was. Bruce Church's complaint was precisely that Arizona was insisting it do something in Arizona (namely, pack its cantaloupes) that it wanted to do in California instead. ${ }^{236}$

It may seem that my argument here is captious, that it trades on a mere accident in the choice of a preposition. I think not. I do not claim the framers were thinking specifically about cases like Pike and chose "in" with the consequences for such cases in mind. I would claim, however, that the framers had a general picture in mind of the sort of effect they intended the privileges and immunities clause to have. The general picture involved foreigners traveling through a state, or seeking to own property, or pursuing a common calling, or appealing to a court. "In" fit naturally as part of a description of that general picture. A case like Pike is not covered by the general picture, in part because it does not involve discrimination against Bruce Church with regard to how it is treated in Arizona. Confirmation of the fact that the choice of "in" was not an accident can be found by considering article IV of the Articles of Confederation (on which the privileges and immunities clause is based).237 The earlier and much wordier provision grants to out-of-staters the privileges and immunities of citizens "in" the several states; it talks about free ingress to and

234. U.S. CoNST. art. IV, § 2, cl. 1.

235. 397 U.S. 137 (1970).

236. Another sort of case that raises a problem about whether the objectionable discrimination occurs in the legislating state is Kassel v. Consolidated Freightways Corp., 450 U.S. 662 (1981), at least if we take the diversion of traffic into neighboring states to be the real harm and citizens and road users in neighboring states to be the real victims.

237. Article IV of the Articles of Confederation reads in part as follows:

The better to secure and perpetuate mutual friendship and intercourse among the people of the different States in this Union, the free inhabitants of each of these States, paupers, vagabonds, and fugitives from justice excepted, shall be entitled to all privileges and immunities of free citizens in the several States; and the people of each State shall have free ingress and regress to and from any other State, and shall enjoy therein all the privileges of trade and commerce, subject to the same duties, impositions and restrictions, as the inhabitants thereof respectively, provided that such restriction shall not extend so far as to prevent the removal of property imported into any State, to any other State of which the owner is an inhabitant; provided also that no imposition, duties, or restriction, shall be laid by any State on the property of the United States, or either of them.

ART. OF CONFEDERATION art. IV, cl. 1. 
regress from the states, thus emphasizing the locational aspect of the topic under discussion; and it talks about equal privileges of trade and commerce "therein" (meaning, in the foreign state where one finds oneself). Article IV of the Articles specifically addresses the matter of removing property from a state (the issue in Pike), and it guarantees a right to remove property imported into that state. Pike is once again strikingly outside the scope of the guarantee.

Supposing that we have surmounted this textual obstacle, it is worth considering briefly what the general doctrinal consequences would be of dropping the dormant commerce clause in favor of the privileges and immunities clauise. Seemingly, the main advantage of the privileges and immunities clause from Black's and Eule's point of view is that it is explicitly about discrimination and only about discrimination. I take it, then, that they would not be tempted to revise privileges and immunities clause doctrine so as to relax that limitation of focus. But I have suggested that in certain areas it may be appropriate for the Court to do more under the dormant commerce clause than simply prevent discrimination. The transportation area is a possibility; the taxation area is a possibility (a certainty unless we decide to locate the fair apportionment principle in the due process clause); and there may be others. These special cases cannot be accommodated under a privileges and immunities clause concerned only with discrimination.

A second doctrinal consequence of reliance on the privileges and immunities clause is that such reliance would strongly suggest going beyond the anti-protectionism principle proper (concerned only with discrimination between competitors) to either the no-singling-out principle or the no-hostile-treatment principle. This may be an advantage of the privileges and immunities analysis - certainly I have no more to say than what I said in section II.D. to anyone who so regards it.

There is a third doctrinal consequence of relying on the privileges and immunities clause that I agree with Charles Black is an unambiguous advantage. As Black says, the "impersonally peremptory language" of the privileges and immunities clause makes that clause a more plausible source than the dormant commerce clause for an antiprotectionism principle that binds Congress as well as the states. ${ }^{238}$ Those of us who are made uncomfortable by sweeping assertions of Congress' power to authorize state discrimination must approve.

But there is another side even to this coin. The same peremptory language that makes it easier to see in the privileges and immunities 
clause some limit on the doctrine of Prudential Insurance Co. v. Benjamin $^{239}$ threatens to overturn Prudential entirely. Given the peremptory language, how can Congress authorize discrimination at all? If we are not totally opposed to Prudential but would just like to retain a possibility of judicial review in case Congress goes overboard (and Black seems to join me on this middle ground), ${ }^{240}$ then neither the peremptory language of the privileges and immunities clause nor the authorization-to-Congress language of the commerce clause is ideal.

Where does all this leave us? It leaves me thinking we should let sleeping dogs lie. The privileges and immunities clause has some attractions, but it can hardly be viewed as a perfect textual basis for antiprotectionism that we have hitherto unaccountably overlooked. Since the Court has been doing reasonably well with the dormant commerce clause (better than the scholars have realized), and since the consequences of doctrinal avulsion are always unpredictable, my vote is for things as they are.

\section{Practice: What the Court Is Doing}

In this final part of the essay I shall look at how the Court has actually been deciding cases. I write separately of theory and practice because the questions what the Court should do and what it is doing are in principle distinct. But my claim, remember, is that in the dormant commerce clause area, and most particularly in movement-ofgoods cases, the Court has been doing just what it should do. In what follows, I shall concentrate exclusively on the claim in regard to movement-of-goods cases, although I shall discuss a few tax cases incidentally, for the light they throw on the anti-protectionism principle.

My thesis, of course, is that in movement-of-goods cases the Court is doing nothing but preventing state protectionism, where protectionism is defined in terms of purposeful favoring of locals over their foreign competitors. Implicit in this thesis are a positive claim and a negative claim. The positive claim, that the Court is engaged in the suppression of purposeful protectionism, is simple and straightforward. The negative claim, that the Court is not engaged in balancing, is actually a bundle of claims corresponding to the various forms of balancing I have previously identified. It would pointlessly complicate the exposition if $I$ attempted to marshal separately the evidence for the various specific negative claims. For the most part, therefore, I shall concentrate on the positive claim and let the negative claims take care

239. 328 U.S. 408 (1946).

240. Black, supra note 3, at 65-66. 
of themselves. By the time I have finished, it should be overwhelmingly clear that the Court is not engaged in any wide-ranging balancing. That is, the Court is not engaged in open-ended private interest balancing and it is not engaged in national interest balancing (in movement-of-goods cases). If the Court is engaged in any sort of balancing, it is engaged in protectionist effect balancing or it is applying just the minimalist effects test of checking to make sure there are some good effects before the law is upheld. But these versions of balancing are best understood as belonging to a purpose-based inquiry, as I have argued elsewhere. ${ }^{241}$

I shall not attempt to establish my thesis by looking just at the Court's results; I shall analyze the major opinions in some detail. The reason is that while the results of the cases are all consistent with my thesis (and rather more clearly consistent with my thesis than with any other), it is not possible to prove my thesis just by looking at the results. Let us see why.

Even proponents of balancing allow that protectionist purpose on the part of the state is a sufficient condition for the unconstitutionality of a law. For example, the famous test formulated in Pike v. Bruce Church, Inc. requires that a state law be aimed at "a legitimate local public interest" and that it have "a legitimate local purpose."242 (The Court has exhibited a remarkable reluctance to rely on explicit findings of protectionist purpose; but that is a separate matter, which I shall explain in section III.E.) So, the only issue between the balancer and myself is whether protectionist purpose is a necessary condition for the unconstitutionality of a law. I say it is necessary; the balancer denies this.

It follows that there is only one kind of case about which the balancer and I disagree, namely, the case where there is no protectionist purpose, but where there are bad effects (whether on foreign private interests or on some putative national interests) that are not justified on balance by the good effects of the law in question. I say the Court

241. See section I.D. and subsection II.A.2. supra. Incidentally, since my main object is to show that the Court is concerned with legislative purpose, I shall ignore in the text the question whether the Court is really limiting itself to the anti-protectionism principle proper (defined in terms of purpose to aid locals vis-à-vis foreign competitors) or whether the Court is perhaps following the no-singling-out principle described in section II.D. as a slightly broader alternative (but one which still focuses on legislative purpose). I shall write as if the Court has adopted the anti-protectionism principle if it is concerned with purpose at all. My justification for doing this, aside from my own variable preference for the anti-protectionism principle over the no-singlingout principle, is that the cases all fit comfortably under the anti-protectionism principle, with only one or two possible minor exceptions that suggest the no-singling-out principle. These exceptions I have mentioned in section II.D. (see text at note 152 supra) or will mention below (see note 472 infra).

242. 397 U.S. 137,142 (1970). 
would uphold such a law; the balancer says the Court would strike it down.

Now, under what circumstances would my position be vindicated just by the result in some case? We would have to find a case where there was no bad purpose, but where there were bad effects on balance, and where the law was nonetheless upheld. The trouble is, it is impossible to identify such a case definitively. It is always open to the balancer to say of any case where the Court upholds the state law that the Court must have decided the effects of the law were acceptable on balance. And the balancing criterion is so mushy that there is hardly any point to insisting that the Court could not have so decided. In sum, even if my thesis is correct, it cannot be proved just by reference to the results in the cases. Hence my excursion through the opinions.

It is worth noting that the situation is not symmetrical: if the balancer were right, it ought to be possible to prove him right (and me wrong) just by reference to the results in the cases. What it would take to prove him right is a case in which there was no protectionist purpose, but the law was nonetheless struck down (in which case the reason would have to be that the Court had disapproved of the balance of effects). Such a case ought to be identifiable with reasonable certainty, if it existed, because the issue of purpose is not nearly so mushy as the issue of the balance of effects. But there is no such case. The fact that there are no results proving me wrong, despite the fact that if I were wrong there ought to be such results, is significant negative evidence in favor of my thesis. ${ }^{243}$

What follows is divided into five sections. In section III.A. we shall consider the leading supposed precedents for balancing in movement-of-goods cases, Pike v. Bruce Church, Inc., ${ }^{244}$ Hunt v. Washington State Apple Advertising Commission, ${ }^{245}$ and Dean Milk Co. v. City of Madison. ${ }^{246}$ We shall see that in all three of these opinions the balancing language is only a veneer which has virtually nothing to do with the Court's effective decision process as revealed in the parts of the opinions where the cases are actually disposed of. In section III.B.

243. Some reader might suggest that Dean Milk Co. v. City of Madison, 340 U.S. 349 (1951), involved no protectionist purpose and is therefore a case of the sort I say does not exist. But the ordinance in Dean Milk was an explicit import embargo, and this explicitness raised a presumption of bad purpose which the otherwise equivocal evidence on purpose was inadequate to rebut. See the extended discussion of Dean Milk in subsection III.A.3. If the reader thinks she has some other counterexample to the claim in the text, the case in question will almost certainly be discussed somewhere below.

244. 397 U.S. 137 (1970).

245. 432 U.S. 333 (1977).

246. 340 U.S. 349 (1951). 
we shall consider four cases in which state laws are upheld. In these cases, ranging from Breard v. Alexandria ${ }^{247}$ up to Exxon Corp. v. Maryland, ${ }^{248}$ Minnesota v. Clover Leaf Creamery Co., ${ }^{249}$ and Commonwealth Edison Co. v. Montana, ${ }^{250}$ there is hardly any suggestion of balancing. (In some of them there is no suggestion of balancing at all.) Section III.C. will be occupied principally with three famous old cases, Baldwin v. G.A.F. Seelig, Inc., ${ }^{251}$ Henneford v. Silas Mason Co., ${ }^{252}$ and H.P. Hood \& Sons v. Du Mond. ${ }^{253}$ Scholars and judges have made these three into "balancing cases," despite the total absence from the opinions of any discussion or endorsement of balancing, by taking quotations out of context. In section III.D. we shall survey briefly the movement-of-goods cases decided since Pike and not already discussed. Finally, in section III.E. I shall offer some explanation of why the Court persists in (sometimes) claiming to balance, even though in fact it never balances.

A. The Leading Precedents for Balancing: Pike, Hunt, and Dean Milk

Pike v. Bruce Church, Inc. ${ }^{254}$ illustrates the neglected adage, "Odd cases make bad law." Pike is not a particularly hard case, but it is decidedly odd, and Stewart, who writes for the Court, is bemused by the oddity. Let us therefore begin not with the opinion, but with the facts of the case and the application to the facts of the anti-protectionism theory.

In issue is the constitutionality of an order by an Arizona agricultural supervisor forbidding Bruce Church to transport cantaloupes grown by it in Arizona into California for packing. The effect of the order is to require that Arizona-grown cantaloupes be processed and packed in Arizona.

As a consequence of being packed in Arizona, these cantaloupes will end up labeled as coming from Arizona. The Court is not clear whether it is an independent requirement of Arizona law that canta-

247. 341 U.S. 622 (1951).

248. 437 U.S. 117 (1978).

249. 449 U.S. 456 (1981).

250. 453 U.S. 609 (1981).

251. 294 U.S. 511 (1935).

252. 300 U.S. 577 (1937).

253. 336 U.S. 525 (1949).

254. 397 U.S. 137 (1970). 
loupes packed in Arizona be so labeled, or whether it is merely standard practice of the industry. But the entire discussion proceeds on the assumption that cantaloupes packed in Arizona will be labeled as Arizona cantaloupes and cantaloupes packed in California will be labeled as California cantaloupes. ${ }^{255}$ In fact, the asserted purpose of the Supervisor's order is precisely to guarantee that these Arizona-grown cantaloupes end up labeled as the product of Arizona. Stewart quotes from the brief for the Supervisor: "It is within Arizona's legitimate interest to require that interstate cantaloupe purchasers be informed that this high quality Parker fruit was grown in Arizona."2s6

Now, applying the anti-protectionism theory, the first question is whether Arizona's purpose is protectionist. The answer is clearly, Yes. This is not a matter of disbelieving the Supervisor's claim. The asserted purpose is protectionist. Why does the Supervisor want interstate cantaloupe purchasers to be informed about the origin of this fruit? Neither the Supervisor nor the purchasers regard that bit of knowledge as valuable in itself. The Supervisor wants purchasers to know where these cantaloupes came from because they are unusually good cantaloupes, and knowledge that they came from Arizona will dispose purchasers of them to buy other cantaloupes from Arizona. If the cantaloupes are labeled as coming from California, California will reap the reputational benefit. In short, the Supervisor wants these cantaloupes labeled as Arizona cantaloupes because that will improve the competitive position of the Arizona cantaloupe industry, in general and as compared to its California competition. Arizona's avowed purpose is protectionist.

On the other hand, this purpose of promoting the reputation of local products is a protectionist purpose that states are often allowed to pursue, because it is often pursued by permissible techniques such as media advertising paid for by a state agency. ${ }^{257}$ What about the technique in this case?

The technique in this case turns out to be a forbidden one - an explicit embargo on the export of unprocessed goods. There is no doubt about that technique's being sufficiently like the traditional weapons of protectionism to be forbidden. It is one of the traditional weapons of protectionism. Some people, including even Stewart in the early portions of his opinion, seem to miss the fact that the Supervisor's order is an explicit embargo. Perhaps they miss this because the

255. 397 U.S. at 144.

256. 397 U.S. at 144.

257. Cf. section II.G. supra. 
order does not distinguish in terms between packers who operate in Arizona and packers who operate in California. The order may therefore seem to confer no advantage on local actors. But the order does confer advantage on locals. The order is stated explicitly in terms of state lines. Its immediate effect is to require packing in Arizona and its inevitable tendency is to advantage Arizona packing workers. In addition, the usual effect of a statute like this, expectable just from its language and with no further empirical knowledge, would be to advantage packing companies that operate in Arizona. If this order will not, it is only because Bruce Church has said that if it is required to conform to the order it will itself become a packing company that operates in Arizona (by building a new packing shed there). This order is an entirely different kettle of fish from the facially neutral statutes with protectionist effect involved in, say, Hunt or Exxon.

So, the Supervisor's order promotes a protectionist purpose by a standard protectionist technique. Under the anti-protectionism theory, the order is unconstitutional.

The conclusion that the order is unconstitutional may, however, be a little harder to swallow than our analysis suggests. Let us see why the case may seem less straightforward than our analysis so far makes it appear. There is a protectionist purpose in Pike, and there is a standard protectionist technique. But the relationship between purpose and technique is nonstandard. The embargo technique usually aims at promoting local business or employment directly; in Pike the embargo (supposedly) promotes local business or employment indirectly through the medium of product reputation. This peculiar indirect relation of technique to ultimate purpose is the main thing that makes Pike odd. And there are subsidiary aspects of the situation that contribute to the oddity. If we rule against Arizona here, it seems that we are ruling against the dissemination of true information, which is normally a great constitutional good. (Ironically, the information in this case, about the origin of these particular cantaloupes, will tend to be misleading if it persuades consumers that all Arizona cantaloupes are exceptionally good. It seems to be agreed these cantaloupes are special. Still, the pure factual information is indisputably true.) Furthermore, Arizona would be perfectly free to disseminate information about the quality of its cantaloupes by normal advertising. Also, the local packing requirement is imposed by the Supervisor under a longexisting statutory scheme whose general purpose is to maintain the reputation of Arizona cantaloupes by preventing deceptive packing. Such a scheme, we have seen, is another standard instance of permissi- 
ble protectionism. ${ }^{258}$

None of the above considerations should incline us to alter our conclusion that the Supervisor's order is unconstitutional. In striking down the order, we would not be disfavoring information, but only the embargo as a technique of disseminating information. State advertising and schemes to promote honesty in packing are permissible, despite protectionist purpose, just because they do not involve any technique like an embargo that is coercive and hostile and that produces substantial market effect at slight expense to the state. The fact that Arizona claims to be interested only in the remote (informational and reputational) effects of its embargo does not alter the coerciveness of the embargo with regard to packers, nor does it raise the cost of the embargo to the state.

And to tell the truth, it is hard to believe that Arizona is motivated only by the remote effects of its embargo, when the immediate effects are similarly pro-local and much more certain. If we had no direct evidence at all concerning Arizona's purpose, the Supervisor's order would fall under the per se rule against explicit embargoes that we discussed in section II.A. It would be supremely silly to say Arizona can avoid the effect of that per se rule by proving a nonstandard, but still protectionist, purpose aiming only at remote protectionist effects. ${ }^{259}$

We are ready now to consider Stewart's opinion, which is as odd in

\section{Section II.G. supra.}

259. Alex Aleinikoff has suggested an illuminating hypothetical. Suppose Arizona required each cantaloupe exported from the state to bear a sticker saying "Grown in Arizona"? Would this embargo on the export of unstickered cantaloupes be unconstitutional on my theory? Subject to certain further assumptions, my intuition says this embargo should not be unconstitutional; and that is also what my theory entails, despite first appearances. As to the further assumptions: First, I simply assume away any possible first amendment issue about compelled speech. Second, I assume that the application of stickers can be done independently of the general packing process without serious loss of efficiency. If this were not the case, the sticker requirement would have the predictable effect of causing the general packing to be done in Arizona, and we would be justified in regarding the sticker requirement, at least presumptively, as a mere cover for an explicit embargo on the export of unprocessed goods like the actual order in Pike. Finally, I assume that sticker applying either is not a part of the normal packing process or else is a sufficiently trivial part so that no state would require local sticker application for the purpose of bolstering the local sticker applying business or local employment in that business. This third assumption (along with the second assumption above) guarantees that Arizona's concern really is with the information content of the stickers. And this third assumption also explains why the sticker law is permissible. The law is exempted from condemnation as protectionist by part (b) of the definition of protectionism. Even though the sticker law can be formulated linguistically as an export embargo, it is not truly analogous to a classical embargo since, by hypothesis, it does not have the immediate effect of capturing any sort of economically significant activity for local actors. (Notice that in this respect the sticker law is different from the actual order in Pike. Notice also that I have no brief for the verisimilitude of my second and third assumptions above. They are made for the sake of the hypothetical. If either is dropped, the sticker law is unconstitutional.) 
its way as the case itself. Despite his talk of balancing, Stewart actually decides the case by virtually the same analysis we have generated in applying the anti-protectionism principle.

After stating the facts and disposing of the Supervisor's contention that his order has nothing to do with interstate commerce because it affects only what is done in Arizona, Stewart states the famous Pike test. I reproduce it here, complete with all citations:

Although the criteria for determining the validity of state statutes affecting interstate commerce have been variously stated, the general rule that emerges can be phrased as follows: Where the statute regulates evenhandedly to effectuate a legitimate local public interest, and its effects on interstate commerce are only incidental, it will be upheld unless the burden imposed on such commerce is clearly excessive in relation to the putative local benefits. Huron Cement Co. v. Detroit, 362 U.S. 440, 443. If a legitimate local purpose is found, then the question becomes one of degree. And the extent of the burden that will be tolerated will of course depend on the nature of the local interest involved, and on whether it could be promoted as well with a lesser impact on interstate activities. Occasionally the Court has candidly undertaken a balancing approach in resolving these issues, Southern Pacific Co. v. Arizona, 325 U.S. 761, but more frequently it has spoken in terms of "direct" and "indirect" effects and burdens. See, e.g., Shafer v. Farmers Grain Co., [268 U.S. 189].260

Note in passing that none of the cases Stewart cites gives any support to balancing in movement-of-goods cases. Huron Cement and Southern Pacific are both transportation cases. The third case, Shafer, Stewart cites mainly as an example of misleading language. Stewart does not explicitly disapprove the argument or result of Shafer; and he may think Shafer is a balancing case beneath its obsolete rhetoric. But if Stewart thinks that, he is almost certainly mistaken. The Court in Shafer does not discuss at all the local benefits claimed for the statute under review. Indeed, the Court explicitly refuses to consider these benefits: "If the [local] evils suggested [by North Dakota] are real, the power of correction does not rest with North Dakota but with Congress ...."261 Shafer was written before the modern era by a Justice (Van Devanter) who believed in the direct/indirect test; it was decided by a Court that believed in the test; and by modern standards, mine or Stewart's, it was probably decided wrongly. To repeat, Stewart's precedents give no support to balancing in movement-of-goods cases.

Having stated his famous test, Stewart proceeds virtually to ignore it. (In fairness, he may not have known it was destined to become

260. 397 U.S. at 142.

261. Shafer v. Farmers Grain Co., 268 U.S. 189, 202 (1925). 
famous.) The first question raised by Stewart's test as he states it is whether the order regulates "evenhandedly"; but Stewart skips over that question without comment. This would be understandable if it were obvious that the order was evenhanded. But in fact it is obvious that it is not. The order is an explicit embargo; it requires that certain cantaloupes, which could be well packed in California, be packed in Arizona instead. What is more, Stewart's eventual resolution of the case is going to turn on the fact that the order is thus un-evenhanded. Already we wonder what is going on.

Instead of considering at this point whether the order is evenhanded, Stewart embarks on a meandering discussion of the purpose of the Supervisor's order and the purpose of the statute on which the order is based. ${ }^{262}$ This discussion of purpose takes up more than half of the remainder of the opinion. Stewart's attention to purpose does not prove he is following the anti-protectionist approach; purpose is central under the anti-protectionist approach, but it is relevant also to Stewart's test, both because the state is required by Stewart's test to have a legitimate purpose and because the purpose is a good guide to what is actually accomplished. Even so, Stewart's perplexity about the legitimacy of the purpose parallels very closely our own discussion from the anti-protectionist point of view. Stewart regards the specific purpose here as a manifestation of a general purpose, to enhance product reputation, which he can neither reject nor endorse without qualification. The reason, we know, is that such a purpose is acceptable if pursued by certain means, but objectionable if pursued by other means such as the order in the case at hand.

In the end Stewart writes: "Although it is not easy to see why the other growers of Arizona are entitled to benefit at [Bruce Church's] expense from the fact that [Bruce Church] produces superior crops, we may assume that the asserted state interest is a legitimate one."263 Notice that Stewart is plainly viewing even the reputation enhancement purpose as protectionist; he speaks of the growers of Arizona benefiting at Bruce Church's expense. (The unfairness is magnified by the fact that they are capitalizing on the quality of Bruce Church's fruit.) Notice also that Stewart cannot bring himself to say the reputation enhancement purpose in the present context is legitimate; he only "assumes" so. And he reveals some doubt about the Supervisor's bona fides, referring for the first time to the reputation enhancement purpose as "asserted."

262. 397 U.S. at 142-44.

263. 397 U.S. at 145. 
Stewart has now brought us to the crux of his opinion. After the quoted sentence in which he assumes that the asserted state interest is legitimate, he continues:

But the State's tenuous interest in having the company's cantaloupes identified as originating in Arizona cannot constitutionally justify the requirement that the company build and operate an unneeded $\$ 200,000$ packing plant in the State. The nature of that burden is, constitutionally, more significant than its extent. For the Court has viewed with particular suspicion state statutes requiring business operations to be performed in the home State that could more efficiently be performed elsewhere. Even where the State is pursuing a clearly legitimate local interest, this particular burden on commerce has been declared to be virtually per se illegal. Foster-Fountain Packing Co. v. Haydel, 278 U.S. 1; Johnson v. Haydel, 278 U.S. 16; Toomer v. Witsell, 334 U.S. 385. ${ }^{264}$

In these four sentences, the case is effectively decided. And if we look closely, we will see a balancing opinion turn into an anti-protectionist opinion before our very eyes.

The first sentence, which concludes with a reference to the $\$ 200,000$ cost to Bruce Church, could be the start of open-ended private interest balancing. But we are told in the next sentence that the nature of the burden is more significant than its extent. Already, then, the balancing is not simply a matter of totting up costs and benefits. Some costs are special. Incidentally, the famous Pike test from earlier in Stewart's opinion says nothing about the nature of the burden being significant. It says the nature of the local interest is significant, but not the nature of the burden. This is one more example of the general lack of connection between the stated test and Stewart's actual process of decision.

Very well, what burdens are specially problematic? The third sentence tells us. The specially suspect statutes are those "requiring business operations to be performed in the home State. . ." (Let me ignore for the moment Stewart's reference to efficiency. I shall return to it.) So, the burden that is specially problematic, at least in the context of this case, is protectionist effect. Or rather, under the broadest possible interpretation of Stewart's language, it is protectionist effect. There is a splendid triple ambiguity in Stewart's word "requiring." "Requiring" could mean "having the purpose of bringing it about that [business operations are performed in-state]"; or it could mean "formulated in terms which explicitly direct that [business operations be performed in-state]"; or it could mean "producing the effect that [business operations are performed in-state]." In other words, statutes that "require" business operations to be performed locally might be (1)

264. 397 U.S. at 145. 
statutes with protectionist purpose, or (2) statutes that (purpose aside) make explicit reference to state lines, or (3) statutes that (purpose and explicit language aside) have protectionist effect.

Perhaps the fourth and final sentence will clarify the meaning of "requiring." The fourth sentence claims to find in Foster-Fountain Packing Co. v. Haydel, Johnson v. Haydel, and Toomer v. Witsell the rule that "this particular burden on commerce" (that is, whatever burden it is that we are talking about) is "virtually per se illegal." So the question becomes, what rule could those cases be thought to establish? Keeping in mind that if we are going to infer a per se rule from only three cases that do not explicitly announce any rule we should be conservative in our inference, the answer is: at most a per se rule against statutes that explicitly require that business operations be performed locally.

In all three cases, the statutes under review were explicit. There was no question of mere protectionist effect from a facially neutral ("evenhanded") statute. As it happens, the Court probably also thought there was protectionist purpose in all three cases. The Court is completely explicit about finding protectionist purpose in the two Haydel cases. ${ }^{265}$ In Toomer the Court is nowhere explicit about its view of the purpose of the local processing requirement; but the Court clearly believes the general scheme under review, which includes discriminatory licensing provisions, has a protectionist purpose. ${ }^{266}$ The Toomer Court never focuses on whether bad purpose is necessary to the result. The reason the Court can ignore this issue about the role of purpose, so interesting to us, is not that the case is decided by pure balancing. It is rather that South Carolina practically conceded the existence of protectionist purpose by relying primarily on the argument that even purposeful protectionism is permitted in a state's dealings with local fish and wildlife. ${ }^{267}$

In sum, we might well say that Stewart's cases establish a per se rule only against statutes with protectionist purpose. But that would be no per se rule at all, since it is apparently agreed on all hands that protectionist purpose is objectionable in itself. Let us concede one more step. Let us allow that the cases establish a per se rule against explicit embargoes. (We have seen that such a per se rule is justified whether these cases establish it or not.) But Stewart's cases most certainly do not justify a per se rule covering facially neutral statutes with

265. Foster-Fountain Packing Co. v. Haydel, 278 U.S. 1, 10 (1928); Johnson v. Haydel, 278 U.S. 16, 17 (1928).

266. Toomer v. Witsell, 334 U.S. $385,388,397 \&$ especially n.30 (1948).

267. See 334 U.S. at 404-05. 
an incidental "embargo effect." Granting Stewart the benefit of the doubt about his precedents, what he has established, and what he relies on to decide Pike, is a per se rule against explicit embargoes. ${ }^{268}$

To complete our analysis of Stewart's crucial four sentences, we must tie up one loose end. In the third sentence of the four, Stewart describes as specially suspect statutes requiring local performance of business operations "that could more efficiently be performed elsewhere." I have so far ignored this qualification, which may seem to sound a balancing note. I wanted to get on and see that Stewart is moving toward a per se rule. Once we know Stewart is moving toward a per se rule, it becomes clear that an inquiry into efficiency can be no part of the actual rule of decision Stewart is suggesting. The question where some business operation can most efficiently be performed is the sort of question that requires a complex investigation. Efficiency is simply not the right sort of thing to use as a trigger for a per se rule. (Explicitness, in contrast, is the right sort of thing, precisely because explicitness is easy to identify.) The reader might suggest that Stewart is not really talking about efficiency in any sophisticated sense; Stewart is merely pointing to the fact that the Supervisor's order will increase Bruce Church's short-term packing costs. Such a cost increase may be easy enough to identify, but there are other reasons for not regarding it as part of the per se rule Stewart is aiming at. A per se rule triggered simply by a cost increase standing alone would be much too restrictive. And if we make the rule less restrictive by adding explicitness (the obvious candidate) as a further necessary trigger, then we find we can dispense with reference to the cost increase. We have a per se rule (in terms of explicitness alone) that is already satisfactory without bothering about the cost increase.

So, efficiency plays no role in Stewart's actual rule of decision. But Stewart does refer to efficiency. What do we make of that? The reference may well be mere window dressing. References to efficiency often are. But there is one other possibility we should at least consider, namely, that efficiency is part of the underlying justification for the per se rule against explicit embargoes that Stewart ends up with.

Now, we know that if the underlying justification that moves Stew-

268. Incidentally, two other pre-Pike cases in which laws were upheld make it certain that the Court had established no "virtual per se rule" against laws with the effect of requiring business operations to be performed locally. Breard v. Alexandria, 341 U.S. 622 (1951) (upholding an ordinance with the effect of requiring much retail selling to be done by locals) (discussed further in subsection III.B.3.); Pacific States Box \& Basket Co. v. White, 296 U.S. 176 (1935) (upholding a law with the effect of encouraging use of local materials in fruit containers). These cases also make it tolerably clear that there was not only no virtual per se rule, there was not even any significant presumption against laws with the effect of requiring local operations. 
art is the anti-protectionism theory, then efficiency indeed is a part of that justification. ${ }^{269}$ I have argued that the role of efficiency in antiprotectionism theory is minor and that the relevant sense of efficiency is weak. But there is enough connection between concern for efficiency and the anti-protectionism principle so that a reference to efficiency in this context is perfectly consistent with the notion that Stewart's underlying theory is anti-protectionism.

One might argue, of course, that the reference to efficiency suggests that the underlying justification for the per se rule against explicit embargoes, in Stewart's mind, is a balancing justification. Notice, however, that the balancing justification for a per se rule against explicit embargoes must itself depend on the anti-protectionist's assumption that explicit embargoes will normally reflect protectionist purpose. After all, if states never had bad purpose, then the only explicit embargoes would be laws like the Wyoming embargo on the export of unprocessed wuzzie meat or the Wisconsin law excluding eighteen-yearold residents of Illinois from Wisconsin bars (both discussed in section II.A.). It is far from clear that such laws would be bad on balance more often than not; so it is far from clear that a per se prohibition on explicit embargoes would be justified by a balancing analysis if bad purpose is not assumed. But if the balancing argument against explicit embargoes depends on the likelihood of bad purpose, while the antiprotectionist argument, which makes purpose central, depends not at all on claims about the balance of effects (remember the minor role played in the anti-protectionist analysis by a special notion of effciency), then is not the anti-protectionist analysis to be preferred? And is not the anti-protectionist analysis what we should attribute to Stewart as his underlying analysis, given that his opinion makes no serious attempt to ground the per se rule against explicit embargoes (except in precedent)?

To summarize our discussion of Stewart's crucial paragraph: In the space of four sentences, Stewart goes from a beginning that looks like open-ended private interest balancing to a conclusion based on a per se rule against explicit embargoes that is best justified by an antiprotectionism analysis. At this point, the case is effectively decided. Pike is meet for decision by a per se rule against explicit embargoes because, as we have noted, the Supervisor's order is an explicit embargo. What Stewart ignored before (the un-evenhandedness of the order) he relies on now.

There are two further paragraphs in Stewart's opinion. In the par-

269. See generally section II.A. supra. 
agraph that follows immediately the passage we have been dissecting, Stewart addresses the Supervisor's claim that the Haydel cases and Toomer are distinguishable from Pike because they involved statutes with express or concealed purpose to promote local employment while the Supervisor's order does not. ("Employment" must be taken to cover not only the existence of jobs but also general business activity if the Supervisor's claim is to be evidently true about the three precedents.) Stewart does not respond, as he might, that the Supervisor's order has the same ultimate purpose, only pursued indirectly. Instead, Stewart says that the Toomer Court "indicated" that bad purpose was unnecessary. 270 Presumably Stewart says "indicated" out of awareness that the Toomer Court does not say this explicitly. Indeed, I think the Toomer Court does not say this even implicitly. As I have mentioned, the role of purpose was not the issue in Toomer. The passage Stewart quotes from Toomer has some language that suggests a balancing approach;271 but taken as a whole, and especially in the context of the whole Toomer opinion, the passage suggests only our per se rule against explicit embargoes.

(Of course, if we have a per se rule against explicit embargoes, then when the per se rule is triggered it is not necessary for the party challenging the state law to adduce further positive proof of bad purpose. In that sense, bad purpose is unnecessary when the per se rule is triggered. But nonnecessity of bad purpose in that sense is consistent with, indeed flows from, the general purpose-based anti-protectionism approach, and it does nothing to suggest that balancing is ever appropriate.)

In his next and final paragraph, Stewart does a remarkable aboutface. The paragraph continues the discussion of Toomer and of Pike's relation to Toomer, and it concludes with an argument $a$ fortiori:

If the Commerce Clause forbids a State to require work to be done within its jurisdiction to promote local employment, then surely it cannot permit a State to require a person to go into a local packing business solely for the sake of enhancing the reputation of other producers within its borders. ${ }^{272}$

In the first clause, Stewart implicitly describes Toomer as involving the purpose "to promote local employment." There is no evidence this is an assumption Stewart has made only for purposes of argument. This is the last sentence of Stewart's opinion; we may assume it reflects what Stewart really thinks about Toomer. So, Stewart thinks of

270. 397 U.S. at 145.

271. 397 U.S. at $145-46$ (quoting 334 U.S. at 403-04).

272. 397 U.S. at 146. 
Toomer as involving protectionist purpose, and he here makes use of just the fact about Toomer that he said in his previous paragraph was irrelevant.

This last sentence of the opinion includes what looks like a limited reappearance of the balancing motif, when the state's interest in product reputation is compared unfavorably to the state's interest in employment. But the force of the comparison in context is just to say that an explicit embargo with the purpose of promoting reputation fares no better than an explicit embargo with the purpose of promoting jobs directly. That, of course, is just what we decided at the end of our analysis of the facts of Pike under the anti-protectionist approach.

Considering now the whole opinion: What is Stewart doing in Pike? At some level, Stewart may think he is balancing; but read as a whole, the opinion strongly suggests that Stewart is moved by more specific considerations. (I am willing to claim that even Stewart would have seen this, if he had read the opinion dispassionately.) Certainly there is no trace of the open-ended private interest balancing or the wide-ranging national interest balancing that the much-quoted Pike test might lead us to expect. The only thing that appears in the balance against the Supervisor's order (supposing for the moment that there is balancing at all) is protectionist effect; and it is important to Stewart that this is, "the nature of the burden." The weight of what goes into the other side of the balance is also determined by anti-protectionist considerations. After a longish discussion of the Supervisor's purpose, revealing the same perplexity we would expect from an anti-protectionist, Stewart grudgingly decides to assume that the reputation enhancement purpose is legitimate (as it is, considered in itself). But he is troubled by the fact that it is protectionist (recall his observation that the other growers of Arizona benefit at Bruce Church's expense); and in his final sentence he sums up his opinion by telling us with a rhetorical flourish that this protectionist purpose cannot be pursued by the protectionist technique of an embargo. (He does not use the word "protectionist," but he says everything necessary to make it clear that the word applies to both purpose and technique.) In between, after revealing that he suspects the Supervisor of even more flagrant protectionist purpose (remember "asserted"), Stewart decides the case by reference to a per se rule against a standard protectionist technique. This per se rule is better justified by anti-protectionist considerations than by balancing; and Stewart infers it from cases that he later reveals he understands as involving protectionist purpose.

This, I submit, is not a balancing opinion. 
In Hunt v. Washington State Apple Advertising Commission, ${ }^{273}$ the Supreme Court struck down a North Carolina statute that was ostensibly aimed at preventing confusion in the marketing of apples and that forbade the use of any grades other than USDA grades on closed containers of apples offered for sale in North Carolina. ${ }^{274}$ The effect of the statute was to deny Washington State apple growers the use in North Carolina of their highly respected state grades and to disadvantage them in other ways as well.

Writing for the Court in Hunt, Chief Justice Burger explicitly disclaims reliance on a finding of protectionist purpose: "[W]e need not ascribe an economic protection motive to the North Carolina Legislature to resolve this case . . ."275 Burger sometimes talks as if he is engaged in wide-ranging national interest balancing: "[W]e are confronted with the task of effecting an accommodation of the competing national and local interests." 276 But in the end, what Burger really claims to be engaged in is protectionist effect balancing: "When discrimination against commerce of the type we have found [i.e., protectionist effect] is demonstrated, the burden falls on the State to justify it both in terms of the local benefits flowing from the statute and the unavailability of nondiscriminatory alternatives adequate to preserve the local interests at stake."277

Protectionist effect balancing is what Burger puts forward as the operative test, and it is clear that if Burger is balancing, it is this very limited sort of balancing that he is engaged in. For that matter, it is clear that if Burger is engaged in protectionist effect balancing, it is as a form of indirect motive review. We have observed previously that the only colorable justification for protectionist effect balancing is as a stand-in for motive review. ${ }^{278}$ Burger does not say this, but he offers no other justification for protectionist effect balancing. And it is not only charity in interpretation that suggests that the motive review justification is what Burger has in mind. We shall see that every section of Burger's opinion reveals at least an indirect concern with legislative motive.

In truth, however, what Burger's opinion really suggests is not protectionist effect balancing as an indirect form of motive review. What

273. 432 U.S. 333 (1977).

274. 432 U.S. at 339 (quoting the statute).

275. 432 U.S. at 352 .

276. 432 U.S. at 350.

277. 432 U.S. at 353.

278. See especially subsection II.A.2. supra. 
the opinion suggests is that Burger is engaged in direct motive review and either does not choose to admit it or, perhaps, does not fully realize it. Everything in the opinion (except for the explicit disavowal of direct motive review and the assertion of the protectionist effect balancing test) reads naturally as part of an exercise in direct motive review. Numerous sections of the opinion not only read naturally but also make best sense on the assumption that direct concern with motive is what drives the argument. And in the extreme case, Burger's discussion of less restrictive alternatives is incoherent unless we read into it a direct concern with the legislature's purpose.

Let us proceed section by section.

As Burger is wrapping up the preliminaries, just before he begins the focused discussion of the case at hand, he attempts to justify a balancing approach. He attempts to explain why the Court must stand ready to "effect an accommodation of the competing national and local interests." $279 \mathrm{He}$ first observes that, despite the commerce clause, the states retain some power to affect interstate commerce by legislating on matters of local concern. But, says Burger, "a finding that state legislation furthers matters of legitimate local concern . . . does not end the inquiry [into the validity of the statute]." 280 If it did, then the commerce clause would be virtually toothless, invalidating legislation only in "the rare instance where a state artlessly discloses an avowed purpose to discriminate against interstate goods."281 In order to avoid this virtual elimination of the dormant commerce clause, Burger indicates, the Court must stand ready to balance.

What Burger says we cannot accept is a commerce clause that comes into play only when a state "artlessly discloses" an avowed protectionist purpose. This description of the problem reveals unmistakably that what Burger is worried about is state laws that have a protectionist purpose but that conceal it instead of disclosing it. Burger is right, of course, to regard such laws as presenting a problem. But the natural corrective for this problem is not balancing; it is motive review. (And the most natural corrective is direct motive review.) When Burger says the Court must engage in balancing lest the commerce clause be rendered toothless, he perpetrates a non sequitur. In sum, even Burger's argument for balancing tends much more naturally to support motive review. And if Burger rejects direct motive review

279. 432 U.S. at 350.

280. 432 U.S. at 350.

281. 432 U.S. at 350 (quoting Dean Milk Co. v. City of Madison, 340 U.S. 349, 354 (1951)). 
(which he seems to do implicitly for the present), he has at least made it clear, right at the outset, that motive is his underlying concern.

With the preliminaries out of the way, Burger turns to the focused discussion of the case before him. The very first thing he does is to emphasize that the North Carolina statute has protectionist effect: "[T]he challenged statute has the practical effect of not only burdening interstate sales of Washington apples, but also discriminating against them."282 Burger elaborates on this point, that the statute is not merely burdensome but discriminatory in its effect, for nearly two pages. It is plainly essential to his view of the case that the bad effects of the statute have the form of protectionist effect.

For all the importance he attaches to showing that the bad effects have the form of protectionist effect, Burger never explains why protectionist effect is specially problematic. He does observe that the North Carolina statute gives the North Carolina apple industry "the very sort of protection against competing out-of-state products that the Commerce Clause was designed to prohibit."283 But he says nothing about just what makes this "the very sort of protection" that is objectionable, and what the objection is.

There is, of course, an obvious reason for thinking it significant that the statute has protectionist effect as opposed to other possible burdensome effects on commerce. Protectionist effect, and only protectionist effect, suggests protectionist purpose.

Not only is this the obvious reason for caring whether the "burden" has the form of protectionist effect; it is the only good reason. We have seen that protectionist effect is not a constitutional disvalue in itself. ${ }^{284}$ Beyond that, even if we were wrong to reject review based on the Carolene Products theory or supposed national interests like general laissez-faire or the interstate movement of goods, these interests and forms of review are too broad to account for Burger's belief in the special status of protectionist effect. If the Court had a mission to promote economic laissez-faire in general, then any sort of interference with the free market would be a relevant burden, not just interferences producing protectionist effect. If the Court had a mission to promote the movement of goods across state lines, as such, then any sort of impediment to movement would be a relevant burden, not just impediments with protectionist effect. If the Court had a mission, as suggested by the Carolene Products theory of the commerce clause, to see

282. 432 U.S. at 350 .

283. 432 U.S. at 352.

284. Subsection II.A.2. supra. 
to it that out-of-state interests were not harmed unjustifiably, then any sort of harm to an out-of-state interest would be relevant, not just harms in the form of protectionist effect. And so on. If the only reason for being specially concerned about protectionist effect is fear of protectionist purpose, then Burger's special concern about protectionist effect is more evidence that his underlying concern is with purpose.

Of course, at this point Burger could still be concerned with purpose only indirectly. Protectionist effect is obviously highly relevant to a direct inquiry into legislative purpose, but it is still possible that Burger genuinely wishes to eschew direct motive review in favor of protectionist effect balancing as a stand-in operational criterion.

I must say, however, that even this section of the opinion, nominally just about protectionist effect, does not read like part of a protectionist effect balancing opinion to me. Burger has not yet introduced his statement of the protectionist effect balancing test. If that were the test that was really guiding his decision, we might expect him to introduce it first and then marshal the evidence and arguments it makes relevant. Instead, Burger has plunged into a discussion of protectionist effect that seems primarily designed to show actual bad purpose on the part of the North Carolina legislature. Only at the end of this discussion does he catch himself up and deny that that is what he is really about. (As we shall see, stronger confirmation of Burger's direct concern with purpose follows his denial.)

After the discussion of protectionist effect, and still before Burger states the protectionist effect balancing test, there is a paragraph devoted explicitly to the issue of protectionist purpose. ${ }^{285}$ It is true that Burger concludes this paragraph by saying he can resolve the case without a finding of bad purpose. But the paragraph strongly suggests both that Burger thinks there was bad purpose and that he wants the reader to share his view. Burger quotes from the record a "glaring"286 statement of the North Carolina Agriculture Commissioner which suggests that the Commissioner viewed the statute as having a protectionist purpose. The statement of the North Carolina Commissioner also reveals that apple producers in North Carolina were the main proponents of the legislation. This does not prove that the legislature's motive was protectionist, but it is suggestive.

Burger goes out of his way to bring these facts to our attention. The statement of the North Carolina Commissioner is the only bit of evidence Burger brings in that is not either mentioned or represented

285. 432 U.S. at 352-53.

286. 432 U.S. at 352. 
by a finding in the district court's opinion. ${ }^{287}$ The district court made no finding on the actual purpose of the statute; indeed it said it was unable to determine the true legislative purpose. ${ }^{288}$ But it also rather pointedly referred to the statute's "purported" purpose of eliminating deception and confusion, on the way to observing that the purported purpose was "irrationally implemented."289 Burger does the same. Though he recoils from openly ascribing a protectionist purpose, he never betrays any inclination to believe that the purpose was innocent. Certainly he never says it was innocent. And he refers more than once to the statute's "ostensible" consumer protection purpose. 290

It seems probable that Burger thought the statute was protectionist but that he was embarrassed by the absence of any finding to that effect in the district court's opinion. That would explain Burger's rehearsing evidence of protectionist purpose from the record at large even as he claimed to decide the case on another ground.

At this point in the opinion, perhaps having come too close to explicit motive review for his own comfort, Burger finally states his protectionist effect balancing test, which I have already quoted. The protectionist effect balancing test requires Burger to consider whether there are any permissible benefits from the statute and whether these benefits could be achieved by means less restrictive of commerce (less productive of protectionist effect).

Notice before we go on that both the inquiry into permissible benefits and the inquiry into less restrictive alternatives are relevant to direct motive review quite as much as to indirect review by protectionist effect balancing. If the statute does little or nothing to secure the benefits North Carolina says it was aiming at, that suggests North Carolina may have been aiming at something else it could not mention. Similarly, if there are other ways to achieve the benefits North Carolina says it was aiming at with less protectionist effect, then perhaps North Carolina chose the means it did because the protectionist effect was one of the things it was after.

But we are not limited to observing that the issues of permissible benefits and less restrictive alternatives are relevant to direct motive review. It turns out, paradoxically, that these portions of Burger's opinion, and especially the discussion of less restrictive alternatives, contain the strongest evidence of all that Burger is looking at legisla-

287. Washington State Apple Advertising Commn. v. Holshouser, 408 F. Supp. 857 (E.D.N.C. 1976).

288. 408 F. Supp. at 861 .

289. 408 F. Supp. at 861 .

290. 432 U.S. at $352,353$. 
tive purpose directly and not just through the lens of protectionist effect balancing.

The most striking aspect of Burger's discussion of the putative benefits of the statute is that the discussion is almost entirely a priori. Except for one offhand footnote reference to a district court finding, ${ }^{291}$ Burger's argument appeals not to evidence about what effects the statute does have, but rather to logical claims (or at least a priori probability claims) about what effects the statute, drawn as it is, must have or not have. Burger argues that a statute forbidding the use of superior Washington grades and allowing the sale of entirely ungraded apples could not produce better informed purchasers; and he argues that a statute regulating the labeling of closed containers could not encourage sophistication in consumers, who never see those containers. ${ }^{292}$ What accounts for this preference for $a$ priori argument? Why is Burger not content to rely on the district court's factual finding? Here is a possible explanation: It is much less plausible to suppose the North Carolina legislature was ignorant of obvious a priori arguments than it is to suppose the legislature made a mistake about a controvertible matter of fact. Therefore the availability of $a$ priori arguments that there could be no good effect tends to show bad purpose much more clearly than would empirical evidence that no good effect had come about. In short, it appears that Burger's mode of argument is dictated by an implicit (but direct) concern with legislative purpose.

Finally, we come to Burger's less restrictive alternative analysis. The first thing to notice is this. I have talked about less restrictive or less discriminatory alternatives, because that is the standard form of the analysis Burger is appealing to. Burger, however, talks about nondiscriminatory alternatives. ${ }^{293}$ This is language apparently more favorable to the State, since adequate nondiscriminatory alternatives will be available less often than adequate less discriminatory alternatives. But when we see Burger's application of the language, we wonder.

Burger says there are nondiscriminatory alternatives to the North Carolina statute, and the first one he mentions is requiring foreign growers who label their apples with a state grade to label them with the applicable USDA grade as well. ${ }^{294}$ On the face of it, however, there is no reason to think this alternative would be nondiscriminatory - no reason, that is, to think it would have no discriminatory effect.

291. 432 U.S. at 354 n.8.

292. 432 U.S. at $353-54$.

293. 432 U.S. at $353,354$.

294. 432 U.S. at 354. 
Judging from the findings of the district court, Washington growers who use Washington grades are not required by Washington law to use USDA grades too. ${ }^{295}$ So Burger's supposedly nondiscriminatory alternative might well require some Washington growers to change their practices; and if it did, it would have some discriminatory effect just as the actual statute does. Burger's alternative would probably be less discriminatory, but it would not be nondiscriminatory, as he claims. Burger's second suggested alternative, forbidding the use of state grades that are not demonstrably equal or superior to the corresponding USDA grades, ${ }^{296}$ would also be likely to have some discriminatory effect. Growers from some states might well be required to stop using perfectly reasonable state grades that just happen not to be directly comparable with the USDA grades.

What accounts for Burger's problematic claims that his proposed alternatives are nondiscriminatory? The answer is obvious. Burger is not talking about effect, but about purpose. When Burger argued earlier that the actual North Carolina statute was discriminatory, he claimed to be talking not about purpose, but about effect. We therefore naturally read "nondiscriminatory," in the context of the less restrictive alternative analysis, as also referring to effect. But that makes a shambles of the argument because, as we have seen, the proposed alternatives have discriminatory effect. What Burger must mean by "nondiscriminatory" in his less restrictive alternative' analysis is "without discriminatory purpose." But then the failure of the actual statute to be nondiscriminatory must be a matter of purpose also. Since the actual statute and the alternatives alike have discriminatory effect, there is no distinction to be drawn between them unless the discriminatoriness of the actual statute resides in its purpose.

It may seem that I have read too much into Burger's use of "nondiscriminatory" instead of "less discriminatory" in his less restrictive alternative analysis; but we shall see the same thing happening in Stevens' opinion for the Court in Exxon Corp. v. Maryland 297 and in Brennan's opinion for the Court in Minnesota v. Clover Leaf Creamery Co., ${ }^{298}$ independently of any less restrictive alternative analysis. The statutes in Exxon and Clover Leaf are both facially neutral (like the statute in Hunt), and both have protectionist effect (like the statute in Hunt). But Stevens and Brennan both distinguish Hunt on the ground that the statute in Hunt was discriminatory in a way the statutes con-

295. 408 F. Supp. at 859 (finding no. 6).

296. 432 U.S. at 354.

297. 437 U.S. 117 (1978).

298. 449 U.S. 456 (1981). 
fronting them are not. They claim not a difference of degree but a difference of kind. The only way to make sense of that distinction is to assume that Stevens and Brennan both remembered the statute in Hunt as involving bad purpose, just as Burger seems to when he is writing the last paragraphs of his Hunt opinion.

To summarize: Burger's entire opinion is of a piece. Both in the passage where Burger attempts to justify his approach and in the pages where he applies it, there is balancing talk on the surface and concern with purpose immediately underneath. If Burger is balancing at all, he is engaged only in protectionist effect balancing, and that as an indirect form of motive review. But the opinion coheres best on the assumption (which one part of the opinion absolutely requires) that Burger is responding directly to perceived bad motive. And so he should be.

Dean Milk Co. v. City of Madison ${ }^{299}$ combines aspects of Pike and Hunt. In Dean Milk the Court struck down an ordinance of the city of Madison, Wisconsin, that made it unlawful to sell milk as pasteurized unless the milk had been pasteurized and bottled at a plant within five miles of the center of Madison. The plant had also to have been inspected by Madison inspectors. The City argued that the five-mile limit facilitated convenient and economical plant inspection.

In his opinion for the Court, Justice Clark never puts forward any canonical formulation of a test for cases such as Dean Milk. If we insist on finding a test, it would be in the following passage:

In thus erecting an economic barrier protecting a major local industry against competition from without the State, Madison plainly discriminates against interstate commerce. This it cannot do, even in the exercise of its unquestioned power to protect the health and safety of its people, if reasonable nondiscriminatory alternatives, adequate to conserve legitimate local interests, are available. ${ }^{300}$

This passage might be taken to require protectionist effect balancing.

Whatever Clark's operative test, it is clear that his underlying concern is with protectionist purpose. After Clark has laid out the factual background of the case, at the point where he begins the legal analysis under the commerce clause, Clark's first observation is that there can be no objection "to the avowed purpose of this enactment." 301 We are

299. 340 U.S. 349 (1951).

300. 340 U.S. at 354 (footnote omitted).

301. 340 U.S. at 353. 
put on notice immediately that Clark has doubts about whether the avowed purpose is the actual purpose.

In the next paragraph, after the passage I have already quoted that suggests protectionist effect balancing, Clark goes on to explain why such an approach is necessary:

A different view, that the ordinance is valid simply because it professes to be a health measure, would mean that the Commerce Clause of itself imposes no limitations on state action other than those laid down by the Due Process Clause, save for the rare instance where a state artlessly discloses an avowed purpose to discriminate against interstate goods. ${ }^{302}$

This is the passage Burger quotes from in Hunt. Clark is plainly afraid that state legislatures (which are rarely "artless") will hide protectionist purpose behind "professions" of good purpose.

Further on, Clark writes: "To permit Madison to adopt a regulation not essential for the protection of local health interests and placing a discriminatory burden on interstate commerce would invite a multiplication of preferential trade areas destructive of the very purpose of the Commerce Clause."303 The picture called up by Clark's phrase "would invite a multiplication of preferential trade areas" is a picture of states purposefully rushing to take advantage of a lapse in the Court's anti-protectionist vigilance. It is not the tamer picture of a certain number of innocently motivated but ineffective statutes with incidental protectionist effect being allowed to stand. Again, what concerns Clark is the threat of unchecked protectionist purpose.

Now, even if Clark's underlying concern is protectionist purpose, he might still adopt protectionist effect balancing as the means of smoking out bad purpose. But I have argued that a more direct concern with purpose is preferable. As it happens, there is a completely natural reading of Clark's opinion that makes it fit under my preferred approach.

The crucial point is that the ordinance in Dean Milk is an explicit embargo, or the equivalent of an explicit embargo. There is no reference to a state line; indeed there is no explicit use of any political boundary. Instead of saying no milk may be sold in Madison that has not been pasteurized in Dane County, the ordinance says no milk may be sold in Madison that has not been pasteurized within five miles of the center of Madison. But this sort of purely geographical classification in terms of arbitrary distances from politically defined points is a sufficiently obvious and dangerous method of simulating classification by political boundaries so that if we have a virtual per se rule against

302. 340 U.S. at 354 .

303. 340 U.S. at 356 . 
embargoes in terms of political boundaries, we ought to apply it to arbitrary geographical embargoes as well.

As to the fact that the geographical area does not even begin to approximate the State of Wisconsin, but rather approximates the County of Dane, and the fact that many Wisconsin milk companies are excluded from dealing in Madison quite as much as the Illinois company Dean Milk, Clark expressly and rightly says that is irrelevant. ${ }^{304}$ A government cannot validate discrimination against a protected class (in this case non-Wisconsin firms) simply by subjecting some members of the nonprotected class to the same burden. (A state could not conserve gas by closing gas stations to all blacks and to whites with odd numbered license plates.) It also bears mention that if all the cities in Wisconsin did what Madison has done, then the whole state would be closed in effect to foreign milk. The entire Wisconsin market would be reserved for Wisconsin processors (and incidentally partitioned among them). ${ }^{305}$

So, the virtual per se rule against explicit embargoes ought to cover the Madison ordinance just as it covered the Arizona Commissioner's order in Pike. The Madison ordinance is of course an embargo on the import of processed goods; this has the same effect of requiring local processing as the Arizona embargo on the export of unprocessed goods.

Now, Clark nowhere speaks of a per se rule against explicit embargoes. But there is much evidence in his opinion that he is responding to the explicitness of the Madison ordinance. In presenting the facts of the case, Clark emphasizes that Dean Milk was forbidden to sell in Madison "solely because its pasteurization plants were more than five miles away." 306 In a passage I have already quoted, Clark describes Madison as "erecting an economic barrier protecting a major local industry against competition from without the State," and as "plainly discriminat[ing] against interstate commerce." 307 This is strong language. It is not at all what one would naturally come up with to describe a law one saw as having merely incidental protectionist effect.

304. 340 U.S. at 354 n.4.

305. The Court again confronted the city-line discrimination issue, and again decided that such discrimination was constitutionally equivalent to state-line discrimination, in United Bldg. \& Constr. Trades Council v. Mayor of Camden, 465 U.S. 208 (1984) (under the privileges and immunities clause). For the mirror image issue of regional discrimination, see the discussion of Northeast Bancorp v. Board of Governors of the Fed. Reserve Sys., 105 S. Ct. 2545 (1985), and Metropolitan Life Ins. Co. v. Ward, 105 S. Ct. 1676 (1985), in section III.D. infra (text at notes 499-508).

306. 340 U.S. at 352 .

307. 340 U.S. at 354. 
If Clark is not thinking here that the ordinance has a bad purpose, then he must at least be focusing on the explicitness of the ordinance. Further on, Clark refers to "the discrimination inherent in the Madison ordinance." 308 "Inherent" makes sense only because the ordinance is explicitly discriminatory. Finally, when Clark comes to describing nondiscriminatory alternatives that Madison might have adopted to guarantee the safety of its milk ("nondiscriminatory" is Clark's word, ${ }^{309}$ as it was Burger's), his first suggestion is that Madison should be willing to inspect pasteurization plants anywhere, charging to the plants the reasonable cost of inspection, presumably including travel costs. ${ }^{310}$ But that alternative is not nondiscriminatory in effect - less discriminatory perhaps, but not nondiscriminatory. Distant plants will have to pay more to be inspected. What the alternative is is either nonpurposeful, or at least nonexplicit. So when Clark talks about discrimination, he is talking about purpose, or at least about explicitness.

We have seen that Clark's underlying concern is with protectionist purpose; we have seen that the Madison ordinance is an explicit embargo and would therefore be forbidden by our virtual per se rule against explicit embargoes (which is best explained as part of a purpose-based anti-protectionism approach); and we have seen that Clark seems to be responding to the explicitness of the ordinance.

In addition to all this, there is evidence in Clark's opinion that he is responding more directly still to perceived bad purpose. Just as Burger in Hunt brings forward a damning statement from the North Carolina Agriculture Commissioner, so Clark gives much play to the opinions of both the Health Commissioner of Madison and the milk sanitarian of the Wisconsin State Board of Health that inspection of pasteurization plants by Madison inspectors was not necessary to protect the safety of Madison's milk. ${ }^{311}$ This testimony, highly suggestive of bad purpose, is also relevant of course to the issue of whether the Madison ordinance has any good effect. But Clark's discussion of the testimony is intertwined with his discussion of nondiscriminatory alternatives, which we have seen cannot be just about discriminatoriness in effect.

A final aspect of Clark's opinion also suggests direct concern with legislative purpose. In his exposition of the facts, Clark mentions that milk from the Madison milkshed is not U.S. Grade "A" milk, but that

308. 340 U.S. at 354.

309. 340 U.S. at 354.

310. 340 U.S. at 354-55.

311. 340 U.S. at 355-56. 
the Dean Milk Company's milk is Grade "A."312 Clark does not say why these facts are relevant, nor does he refer to them explicitly in his legal analysis of the case. Now, these facts could be relevant simply to the question whether the Madison ordinance has any good effect, since they tend to suggest that Dean Milk's milk is at least as good as what is already sold in Madison. Against that interpretation is the following comment by Clark: "However, Madison contends and we assume that in some particulars its ordinance is more rigorous than that of Chicago." 313 The fact that Dean Milk's milk is Grade "A" while Madison's milk is not might also be relevant to purpose, and relevant otherwise than just as evidence that the health benefits of the Madison ordinance are supposititious. The difference in grades might explain why Madison milk producers are worried about the foreign competition in the first place. There is no difficulty understanding the political power of the local dairy industry in Madison politics. It is easy to assume that the dairy industry could get legislative protection if it wanted it. But without knowing about this distinction in U.S. grades between the local and foreign milk, we might wonder why foreign milk would pose a threat in the Madison market. Do Newcastle's collieries need protection against foreign coal?

Lest I seem to have overargued my case on Clark's direct concern with legislative purpose - I do not claim that Clark's opinion in Dean Milk contains as much evidence of direct concern with purpose as Burger's opinion in Hunt. Clark does not engage in a priori argument against the possibility of good effects from the ordinance; and "nondiscriminatory" in the context of Clark's discussion of nondiscriminatory alternatives could mean either "without discriminatory purpose" or just "not explicit." ("Nondiscriminatory" could not mean just "not explicit" in Burger's discussion of nondiscriminatory alternatives. Nonexplicitness would not distinguish Burger's suggested alternatives from the actual statute in Hunt, which was itself nonexplicit, unlike the ordinance in Dean Milk.)

But if there is somewhat less evidence of a direct judicial response to perceived bad purpose in Dean Milk, that is explainable consistently with the anti-protectionism theory by the fact that a direct perception of bad purpose is not necessary to decide Dean Milk (under the antiprotectionism theory) as it was necessary to decide Hunt. We have seen that the ordinance in Dean Milk comes under a strong negative presumption, the "virtual per se rule" against explicit embargoes. 
There was no such presumption applicable to the law in Hunt. All Clark has to do to strike down the Madison ordinance is decide that the evidence about legislative proceedings, putative good effects, and less restrictive alternatives does not make such a clear showing of innocent purpose as to rebut the presumption against the ordinance. Burger, in contrast, had to be positively persuaded by the evidence before him of the existence of bad purpose (as I have argued that he was).

In sum, Dean Milk was correctly decided, even though it is possible that the Madison ordinance was innocently motivated. The proper analysis of Dean Milk is in terms of a strong presumption against explicit embargoes, plus a decision that the evidence does not rebut the presumption in this case. Clark does not make this analysis explicit. But then, he does not make any analysis explicit. Clark does seem to be responding both to the explicitness of the ordinance and to the strong suggestion in the facts of bad purpose. Clark's opinion is best read as embodying implicitly the analysis I have proposed.

There they are - Pike, Hunt, and Dean Milk. Who would imagine, if he did not know it to be true, that these are the balancer's prime exhibits?

\section{B. A Selection of Cases Upholding State Laws: Exxon, Clover Leaf, Breard, and Commonwealth Edison}

In this section I shall discuss four leading cases upholding state laws - Exxon Corp. v. Maryland, ${ }^{314}$ Minnesota v. Clover Leaf Creamery Co., ${ }^{315}$ Breard v. Alexandria, ${ }^{316}$ and Commonwealth Edison Co. v. Montana. ${ }^{317}$

These cases do not constitute a completely natural grouping. $E x$ xon, Clover Leaf, and Breard are the leading cases upholding state laws with protectionist effect. Of these, Exxon and Clover Leaf are recent decisions, while Breard provides a connection with an earlier period, the period of Dean Milk and H.P. Hood \& Sons v. Du Mond. ${ }^{318}$ Commonwealth Edison Co. v. Montana is like Exxon and Clover Leaf in being an obviously important recent case, and that is why I discuss it here. But it involves a statute with no protectionist effect at all. The reader will remember that in section II.D. we used the Montana coal severance tax as an example of a statute that might violate the "no-

314. 437 U.S. 117 (1978).

315. 449 U.S. 456 (1981).

316. 341 U.S. 622 (1951).

317. 453 U.S. 609 (1981).

318. 336 U.S. 525 (1949). 
hostile-treatment" principle but that could not violate the "no-singling-out" principle (or, a fortiori, the anti-protectionism principle) since no parties similarly situated except for their political allegiance were treated differently, even in effect.

Commonwealth Edison also differs from the other three cases in being a tax case, but that is of no significance. What is striking about Commonwealth Edison is that the Court so clearly eschews balancing and the Carolene Products approach. There is no reason why these approaches, if they were relevant to movement-of-goods cases, should not be relevant to tax cases as well. So the fact that the Court avoids them in a tax case is evidence of their irrelevance to movement-ofgoods cases.

Exxon Corp. v. Maryland ${ }^{319}$ came as a shock to believers in balancing. The statute under review prohibited producers or refiners of petroleum from operating service stations in Maryland. Maryland defended the statute as a means of preventing discrimination against independent service station operators by producers or refiners during times of oil shortage. The Court upheld the statute even though it may well have caused significant inefficiency in gasoline distribution in return for very slight benefits. Even more remarkable, in the face of a vigorous balancing dissent, ${ }^{320}$ seven Justices signed an opinion that engaged in no balancing, that dismissed as irrelevant the sort of considerations balancers think must be balanced, and that did not even cite Pike v. Bruce Church, Inc. Stevens wrote the opinion of the Court; Burger, Brennan, Stewart, White, Marshall, and Rehnquist signed on without writing any qualifying concurrences; Powell took no part; and Blackmun was the lone dissenter.

Why does Stevens uphold the statute? He says the statute neither discriminates against nor burdens interstate commerce. ${ }^{321}$ But given the statute's obvious effects on interstate commerce, which must include substantial diversion of retail business from out-of-state to instate actors, at least in the short run, how can he say that?

Stevens appears to have two principal arguments. First, he emphasizes that because there are no producers or refiners of petroleum in

319. 437 U.S. 117 (1978).

320. 437 U.S. at 134-52 (Blackmun, J., dissenting).

321. 437 U.S. at 128-29. The reader might notice that on certain occasions Stevens says the statute does not impermissibly burden commerce. 437 U.S. at 127. But at pages 128-29 Stevens more than once says simply that there is no burden. See especially the passage quoted in the text at note 333 infra; see also note 333, where I comment further on the significance of the omission of "impermissibly." 
Maryland, the statute will not affect the total volume of gasoline flowing into Maryland from out-of-state. ${ }^{322}$ (This is not strictly true if the statute raises prices, unless demand is perfectly inelastic; but we can ignore this point and treat what Stevens says as true, since it turns out not to be essential.) Second, Stevens points out that the statute does not discriminate explicitly against out-of-state firms. The avowed purpose is not protectionist; the statute makes no distinction on its face between local and foreign firms; and indeed foreign retail chains are still perfectly free to sell gasoline at retail in Maryland, so long as they are not affiliated with a producer or refiner. ${ }^{323}$

These arguments, even taken together, cannot constitute a complete explanation of the validity of the statute. We have only to imagine that the very same statute, with the same avowed purpose, is passed by some state like Maryland for the actual purpose of diverting retail business away from foreign firms (as foreign) and to local retailers (as local). The statute would still not diminish the flow of gasoline into the state; it would still not discriminate avowedly or explicitly; and it would still leave open the possibility that foreign retail chains might enter the market. But the statute would be unconstitutional because of its protectionist purpose, as Stevens himself would surely agree. ${ }^{324}$

If Stevens agrees that protectionist purpose, even if dissimulated, invalidates a statute, he must have believed as he wrote Exxon that there was no protectionist purpose. Indeed, he clearly attributes an innocent purpose to the Maryland legislature in the brief section of his

322. 437 U.S. at 125,126 n.16.

323. 437 U.S. at 125-26.

324. If evidence is required that Stevens would agree about the unconstitutionality of this hypothetical statute adopted with protectionist purpose, it can be found in his dissent in Minnesota v. Clover Leaf Creamery Co., 449 U.S. 456, 477-89 (1981) (Stevens, J., dissenting). Complaining about the majority's treatment of the issue of actual purpose, Stevens writes: "As the majority acknowledges, if a state law which purports to promote environmental goals is actually protectionist in design, a virtually automatic rule of invalidity . . . is applied." 449 U.S. at 487 n.13. (Why only "virtually" automatic? Presumably because of the state-as-market-participant exception and its analogues. See section II.G. supra.)

The astute Justice-watcher might point out that Stevens appears to reject motive review in his dissent in Bacchus Imports, Ltd. v. Dias, 468 U.S. 263, 287 n.15 (1984) (Stevens, J., dissenting). I shall not stop to explain why I think that in context Stevens' comments in Bacchus Imports are not really inconsistent with the commitment to motive review evidenced in Clover Leaf. Suffice it to say that if they are inconsistent, that merely shows that Stevens speaks out of both sides of his mouth on motive review, as many other Justices do as well, and as the Court has done for two centuries. Given this history of equivocation, the statements in favor of motive review are stronger positive evidence for the claim that the Court (or any Justice) engages in such review (when it is appropriate) than the statements decrying motive review are negative evidence against that claim. Notice that since Bacchus Imports, Stevens has written the opinion of the Court in Wallace v. Jaffree, 105 S. Ct. 2479 (1985), a pure motive review case under the establishment clause. 
opinion on the substantive due process argument. 325 Stevens may have been mistaken (more on that possibility later), but he sees no protectionist purpose. Once we are clear about that, we can see also that the absence of protectionist purpose settles the case for him. Nothing else matters.

Consider Stevens' discussion of Hunt. Stevens claims explicitly that the North Carolina statute in Hunt discriminated in a way the Maryland statute does not. ${ }^{326}$ Notice what he does not say. He does not say that while the Maryland statute has disparate effects on foreign participants in the Maryland retail gasoline market, these disparate effects are less than the disparate effects of the North Carolina statute on Washington apple growers, either absolutely or relative to the benefits from the statute. For Stevens, the difference between the Maryland statute and the North Carolina statute is not a difference of degree, such as a balancer might rely on. It is a difference of kind. But, as Blackmun points out in his dissent, if we consider the effects of the two statutes, there is no difference in kind. ${ }^{327}$ Neither statute bars foreign competitors of the relevant local actors explicitly. Both statutes interfere with the most important source of foreign competition, while leaving certain other foreign competitors unaffected. Indeed, the Maryland statute is worse in one way: it flatly excludes the most important foreign competitors, while the North Carolina statute merely hampers them. Blackmun is right on all these counts, but he misses the obvious inference: Stevens is not ultimately concerned with effects at all.

Stevens says North Carolina discriminated and Maryland does not. There is only one thing he can possibly have in mind, namely, that the North Carolina legislature was motivated by protectionist purpose, while the Maryland legislature was not.

If this is what Stevens has in mind, why does he not say so? $\mathrm{He}$ does say that Maryland's purpose was innocent. ${ }^{328}$ What he omits to say explicitly is that North Carolina's purpose was guilty. But if the Court was unwilling to say that explicitly in Hunt itself, it is not surprising that Stevens would not say it here. I have argued that the opinion in Hunt strongly suggests bad purpose was the crux. Stevens participated in Hunt and knew what it was about. His treatment of Hunt in Exxon only a year later makes no sense unless protectionist purpose is the real issue in both cases, as I have claimed.

325. 437 U.S. at 124-25.

326. 437 U.S. at 126.

327. 437 U.S. at 145-48 (Blackmun, J., dissenting).

328. 437 U.S. at 124-25 (at the end of the substantive due process discussion). 
I said earlier that Stevens dismissed as irrelevant various considerations the balancer thinks must be balanced. Certainly Stevens is not interested in private interest balancing or in wide-ranging national interest balancing. He is totally unmoved by claims that some refiners may be pushed out of the retail market entirely, ${ }^{329}$ that consumers may lose "certain special services," 330 that the statute may alter the market structure, ${ }^{331}$ and that the consuming public may be injured. ${ }^{332}$ These arguments relate "to the wisdom of the statute, not to its burden on commerce." 333 Stevens is also not interested in protectionist effect balancing. Protectionist effect does not amount to discrimination in Stevens' eyes, since he says the statute does not discriminate; ${ }^{334}$ and protectionist effect does not give rise to a burden of justification by a showing of actual good effects, since Stevens all but concedes the statute may have no good effects. ${ }^{335}$ In sum, bad effects are not necessarily burdens, and disparate impact is not necessarily discrimination. By implication (and speaking now only of movement-of-goods cases), what makes a bad effect a burden and what makes disparate impact discrimination is bad purpose, a purpose aimed at foreign commerce as such.

To return to where we began, what is Stevens doing when he insists (irrelevantly) that the statute does not diminish the flow of gasoline into Maryland, and when he seems to give such weight to the fact that the statute does not explicitly exclude foreign firms as such and therefore leaves some foreign firms free to sell at retail in Maryland? The second point, about the lack of explicitness and the possibility of foreign competition, is of course highly relevant to the issue of purpose. If Stevens writes in such a way as to suggest that it is dispositive on the issue of purpose (which we know he does not believe), that may be an overreaction to Blackmun's claim that protectionist purpose is not even necessary to the invalidity of the statute. ${ }^{336}$ As to Stevens'

329. 437 U.S. at 127.

330. 437 U.S. at 127.

331. 437 U.S. at 127 .

332. 437 U.S. at 128 .

333. 437 U.S. at 128. Notice that what Stevens says here is not that there is no "impermissible" burden, but that there is no burden, period. ( $C f$. note 321 supra.) Obviously Stevens is not denying that some parties operating in interstate commerce are made worse off by the statute. That would be palpably silly. What Stevens is saying, when he says there is no burden, is that there is no effect on commerce which requires the Court to intervene or even to consider seriously (by "balancing") whether to intervene. None of the manifold effects mentioned in the text suggests to Stevens any ground at all for judicial investigation of the legislative wisdom of the statute.

334. 437 U.S. at $126,128-29$.

335. 437 U.S. at 128.

336. 437 U.S. at 150 (Blackmun, J., dissenting). 
point about the undiminished flow of gasoline, this also strikes me as an overambitious response to an argument Stevens imagines someone raising against him, namely the argument that a diminution of flow is a burden on commerce requiring balancing. Stevens would obviously (and correctly) deny that mere diminution of flow is significant. Unfortunately, instead of saying that, he says there is no diminution. That may be true, but it isn't the point. ${ }^{337}$

Let me say a word now about Blackmun's dissent. I referred to it above as a "balancing" dissent, in a context where I wanted to emphasize Blackmun's insistence that protectionist purpose is not the only issue. But Blackmun does not engage in any wide-ranging balancing, nor does he claim to. Blackmun's explicit theory is protectionist effect balancing along the lines stated by Burger in Hunt. ${ }^{338}$

We have seen already that protectionist effect balancing, which if genuine is best understood as an indirect form of motive review, may not be genuine. It may mask direct motive review. I suspect it does so for Blackmun. There is strong evidence in Blackmun's opinion that he believes the Maryland legislature's purpose was protectionist. At one point Blackmun observes that one of Stevens' arguments, taken literally, would invite purposeful protectionism, showing the states just how to get away with it. Blackmun describes Maryland as following Stevens' implicit prescription for protectionism step-by-step, ending up with the actual Maryland statute, which Blackmun then labels "ingenious discrimination."339 The word "ingenious" in this context indicates a covert purpose to discriminate, cleverly dissembled. It is just barely possible that Blackmun means his story to be about what Maryland might have done, as opposed to what he believes it did. But that is not the way I read it.

My thesis that movement-of-goods cases are being decided by a purpose-based analysis that often requires direct motive review is primarily a thesis about the behavior of the Court - it is not necessary that I show the thesis to be true of every individual Justice. As it happens, I think the thesis may well be true of every Justice now on the Court. ${ }^{340}$ In any event, my comments on Blackmun's dissent are intended to suggest that the same sort of analysis that reveals an un-

337. There is no reason to think the Supervisor's order in Pike v. Bruce Church, Inc., 397 U.S. 137 (1970), would have diminished the ultimate flow of cantaloupes across state lines, but that did not save the order from invalidation.

338. 437 U.S. at 136 (Blackmun, J., dissenting).

339. 437 U.S. at 147 (Blackmun, J., dissenting).

340. The one Justice, past or present, who strikes me as possibly a genuine balancer is Justice Stone. See the discussion of Parker v. Brown, 317 U.S. 341 (1943), in section III.C. infra (text at notes 421-22). But I have not asked myself the question specifically about each and every Justice. 
derlying concern with purpose in the opinions of the Court will reveal that concern in most dissents as well.

One last observation about Exxon. The Court may have been mistaken in its belief that Maryland's purpose was innocent. Without having read the legislative history for myself, I am prepared to believe with the Court that the purpose was innocent. Certainly there is a much more plausible legitimate purpose to credit here in Exxon than there was in, say, Hunt. Still, I can understand how someone might doubt the bona fides of the Maryland legislature. I want to point out, therefore, that all I claim is that the Court is ultimately concerned with legislative purpose; I do not need to claim the Court always makes the right decision about what the legislature's purpose was. (Of course, it would raise doubts about my thesis if I had to explain away a large number of outcomes as based on factual mistake; but in fact I am confident my theory, properly applied, judges fewer outcomes mistakes than does almost any other theory.) As I say, the Court may have been wrong on the facts in Exxon. If it was wrong, that is ironic, because in Exxon it is clearer than in almost any other case that the Court was looking at purpose, whether or not it saw truly. ${ }^{341}$

In Minnesota v. Clover Leaf Creamery Co., ${ }^{342}$ the Court upheld a Minnesota statute prohibiting the sale of milk in plastic nonreturnable containers. Minnesota justified the statute as an environmental and energy conservation measure. One effect of the statute was to divert some business from foreign producers of plastic resins to local producers of wood pulp. Justice Brennan writes the opinion of the Court.

Unlike Stevens in Exxon, Brennan quotes the Pike test and explicitly claims to balance. ${ }^{343} \mathrm{He}$ does not deny the relevance of purpose;

341. And now one last footnote observation about Exxon. Mark Tushnet has suggested to me that I am wrong to treat Exxon as a movement-of-goods case: because the commodity involved was gasoline, the Maryland law actually posed a threat to the efficiency of the interstate transportation network, which has gasoline as a major input. So the Court should have balanced.

There is a point here that I am willing to concede, indeed to embrace. A state law might implicate the national interest in an effective transportation network even though it did not, on its face, regulate transportation. Such a law would give rise to a transportation case, for my purposes. There would indeed be a plausible ground for balancing. $C f$. text at note 174 supra.

But none of this affects the treatment in the text of Exxon. Even if the Maryland law had bad effects on balance on the market for gasoline, there was no suggestion that these effects were so substantial as to affect significantly the transportation network. Furthermore, my main concern is with what the Court was actually doing in Exxon. The Court was plainly viewing Exxon as a movement-of-goods case; and in that context what is important is that the Court definitely did not balance.

342. 449 U.S. 456 (1981).

343. 449 U.S. at $471,472-74$. 
indeed, he specifically finds that Minnesota's purpose was innocent. ${ }^{344}$ But he claims that the finding of innocent purpose does not settle the case, that there is still balancing to be done. Since Brennan eventually finds for Minnesota on the balancing issue also and therefore upholds the statute, Clover Leaf is not the sort of case whose result could prove that I am wrong and the proponent of balancing right about what the Court is doing. But still, what of the balancing rhetoric?

For myself, I think there are many indications that balancing plays no role in Brennan's actual decision process and that what determines the outcome of the case is Brennan's view of Minnesota's purpose.

First off, it is worth noticing that Brennan gets the Pike test right, as self-proclaimed balancers often do not. Brennan remembers and refers repeatedly to the fact that according to Pike the statute must be upheld unless the burdens on commerce are "clearly excessive."345 As I have pointed out previously: If the only relevant burden is protectionist effect (and that is the only burden the Court has even made a pretense of taking seriously in movement-of-goods cases, as well as the only burden Brennan seriously considers here), then Pike calls for weak protectionist effect balancing, which is as close to direct motive review as one can get without being explicit about it.

Turning to Brennan's handling of the facts of Clover Leaf, we see that the section of Brennan's opinion in which he purports to balance is completely perfunctory. ${ }^{346}$ Brennan says there is some burden on commerce. In that case, there must be some benefit from the statute if the burden is to be justified on balance. When it comes to identifying the benefit, Brennan refers back to his discussion of possible benefits in the section of the opinion dealing with equal protection. ${ }^{347}$ In the equal protection discussion, however, Brennan stressed again and again that it was not the function of the Court to decide whether there actually were any benefits; the only question was whether the legislature might have thought there would be benefits. ${ }^{348}$ In short, Brennan never directly addresses the question whether there are any actual benefits to justify the burden on commerce.

Even the discussion of the burden on commerce in the balancing section of Brennan's opinion reflects more concern with purpose than with genuine balancing. Brennan makes no serious effort to quantify or evaluate the burden. His nearly exclusive concern is to minimize

344. 449 U.S. at 471 n.15.

345. 449 U.S. at $471,472,473,474$ ("clearly outweighs").

346. 449 U.S. at $472-73$.

347. 449 U.S. at 473.

348. 449 U.S. at $464,466,469$. 
the degree to which the burden of the statute falls disproportionately on foreigners. ${ }^{349}$ So, his object seems to be to reconfirm what he claims already to have decided, that the statute could well have been passed for the innocent purposes the legislature claimed.

Brennan's treatment of Hunt is also revealing. Like Stevens in Exxon, Brennan insists that Hunt involved discrimination of a kind that is absent in the case before him. ${ }^{350}$ But this claim about Hunt is as inappropriate here, at least on the face of things, as it was in Exxon. The North Carolina statute in Hunt and the Minnesota statute in Clover Leaf are both facially neutral, both have asserted innocent purposes, and both have protectionist effects. If North Carolina discriminated in a way Minnesota did not, it is only because the former had a bad purpose while the latter had the innocent purpose it claimed. Brennan's eagerness to recharacterize Hunt in terms of purpose not only confirms what I have already said about the true meaning of Hunt; it also supports the notion that purpose is the principal category of Brennan's thinking in Clover Leaf.

There is no denying that in Clover Leaf, as in many other cases, the Court claims to balance. And the Clover Leaf opinion is short enough (in its commerce clause section) and mushy enough so that if it stood alone we might do as well to take it as a balancing opinion (though not a very satisfactory one) as to take it as an anti-protectionist opinion. But against the general background of modern commerce clause jurisprudence which we are engaged in reinterpreting, Clover Leaf appears as just one more case that talks about balancing but turns on the issue of purpose. ${ }^{351}$

In Breard v. Alexandria ${ }^{352}$ the Court upheld a city ordinance forbidding most unsolicited door-to-door selling. One effect of the ordinance was to prevent national companies from selling magazine subscriptions door-to-door, and thus to benefit local newsstands and the like.

There is not much to be learned from Reed's majority opinion. Reed does not explicitly engage in balancing (except in that part of the

349. 449 U.S. at $472-73$.

350. 449 U.S. at 471 n.15, 472.

351. It is worth mentioning that while there are two dissenters in Clover Leaf (Powell and Stevens), both are moved primarily by the fear that the Court has mishandled the lower courts' factual findings and has overlooked an actual protectionist purpose behind the statute. See 449 U.S. at 474-77 (Powell, J., dissenting); 449 U.S. at 486-89 (Stevens, J., dissenting).

352. 341 U.S. 622 (1951). 
opinion dealing with the first amendment challenge to the ordinance $\left.{ }^{353}\right)$, but neither does he rely explicitly on any other general theory of commerce clause review. Certainly it is easy to believe the ordinance was passed for the legitimate purpose of protecting householders' privacy, and to believe this was dispositive for Reed. Reed dismisses the suggestion that the ordinance was passed at the selfish request of local retailers as "unsupported in the record." 354 Perhaps the ordinance could have been upheld on a balancing analysis also, but the purpose analysis seems simpler and fully adequate.

There is one feature of Reed's opinion that suggests he was thinking along specifically anti-protectionist lines. Reed undertakes to distinguish Breard from Nippert v. City of Richmond, ${ }^{355}$ which we have already mentioned in section II.F. In Nippert the Court struck down a flat-rate drummer's license tax. What Reed says is this: "Taxation that threatens interstate commerce with prohibition or discrimination is bad [citing Nippert], but regulation that leaves out-of-state sellers on the same basis as local sellers cannot be invalid for that reason." 356 Now, since the tax in Nippert and the ordinance in Breard were both nondiscriminatory on their face and both had some protectionist effect, it may seem that there is no sense in which the Breard ordinance but not the Nippert tax "leaves out-of-state sellers on the same basis as local sellers." But there is a difference in the nature of the protectionist effect.

The tax in Nippert, because it was a flat-rate tax, might affect differently interstate drummers (who are likely to cover a large territory) and local drummers (who are likely to concentrate their efforts). The ordinance in Breard, in contrast, affected interstate drummers and local drummers in exactly the same way - both were put out of business. To be sure, local store owners may have benefited from the Breard ordinance, in part at the expense of interstate drummers. But if local store owners are affected differently than interstate drummers, they also differ from interstate drummers in a respect other than merely being local as opposed to interstate. They do not knock on doors. It is one thing to discriminate in effect between foreign and local drummers and quite another thing to discriminate in effect between foreign drummers and local store owners.

What I have just said, of course, does not prove that the Nippert tax was passed with bad purpose. (Nor does it prove the Breard ordi-

353. 341 U.S. at 644-45.

354. 341 U.S. at 639.

355. 327 U.S. 416 (1946).

356. 341 U.S. at 638. 
nance was not.) It might make us think there should be a purposebased presumption against certain flat-rate taxes to go with the presumption against explicit discrimination. But we have seen in section II.F. that there is a broader reason to be suspicious of flat-rate taxes (or analogues like qualification-to-do-business requirements applied to entities with minimal contacts). Flat-rate taxes may discriminate in effect against multistate businesses as such (which is not precisely the same thing as discriminating against foreign businesses), and we may disapprove that effect regardless of purpose. In any event, I called attention to Reed's treatment of Nippert only to emphasize that Reed seems to be thinking along anti-protectionist, not balancing, lines.

\section{4}

I have already summarized the facts of Commonwealth Edison Co. v. Montana ${ }^{357}$ (in section II.D.), and I have already explained why the case is relevant here even though it involves a tax. It remains only to discuss Marshall's opinion for the Court upholding the tax.

Marshall neither balances nor claims to balance. He affirms at one remove the judgment of the trial court, which dismissed challenges to the tax without receiving any evidence. ${ }^{358} \mathrm{He}$ definitively rejects arguments against the tax that embody the Carolene Products theory of the dormant commerce clause. ${ }^{359}$

Appellants argued that Montana was exporting its tax burden to other states; that Montana was exploiting its market power in lowsulfur coal; that Montana's tax was unreasonably high. All of these claims Marshall sweeps away with the observations that the tax does not discriminate ${ }^{360}$ and (in effect) that it does not matter that the burden of the tax is borne primarily by out-of-state consumers. ${ }^{361}$ Later Marshall reiterates that it does not matter that interstate commerce is affected. 362 The states have a broad discretion in taxing activities within the state, ${ }^{363}$ and the Court does not sit to review the level of taxes. ${ }^{364}$

(The two last mentioned points might seem to apply specially to tax cases, but that is more a matter of rhetoric, admittedly very tradi-

357. 453 U.S. 609 (1981).

358. 453 U.S. at 613.

359. See especially 453 U.S. at 618-19.

360. 453 U.S. at 619.

361. 453 U.S. at 618-19.

362. 453 U.S. at 623.

363. 453 U.S. at 622-23.

364. 453 U.S. at $627-28$. 
tional rhetoric, than of substance. The states have a broad discretion in regulating activities within the state as well as in taxing such activities; indeed we have seen that the states' power to tax is actually subject to more dormant commerce clause constraints than is the power to regulate. ${ }^{365}$ Also, if the level of a tax seems a particularly arbitrary choice, so are many line-drawing decisions in the formulation of regulatory programs. Regulatory programs may even include decisions exactly analogous to choosing a tax rate, such as setting a minimum price. ${ }^{360}$ )

Marshall's crucial claim that the tax does not discriminate is elaborated as follows: the tax makes no distinction on its face between coal destined for local and foreign use; ${ }^{367}$ the tax is administered evenhandedly; ${ }^{368}$ and "the tax burden is borne according to the amount of coal consumed and not according to any distinction between in-state and out-of-state consumers." 369 Marshall never really explains why it is important that the tax is measured by the amount of coal consumed, but he cites Nippert 370 and we can observe that using that measure prevents any Nippert-like discriminatory effect between local and foreign consumers. (It would be a most unusual tax that had a significant Nippert-like effect in the present context, but Marshall's comment could still indicate a general preference for non-flat-rate taxes. The comment occurs in the context of trying to make something out of the "fourth prong" of the Complete Auto Transit ${ }^{371}$ test.)

What Marshall has to say can be summed up quite nicely in the observation that the tax is not protectionist. No local economic actor is favored, even in the effects of the statute, vis-à-vis any foreign competitor. Local citizens may be benefited at the expense of foreign consumers of coal and electricity. But the local citizens are benefited as citizens - as beneficial owners of the state's revenues - not as consumers. As citizens, they do not compete with foreign consumers (nor, of course, with foreign citizens); as consumers, they are treated the same as their foreign counterparts. In short, there is not even protectionist effect, much less protectionist purpose.

365. See section II.F. supra.

366. E.g., Cities Serv. Gas Co. v. Peerless Oil \& Gas Co., 340 U.S. 179 (1950), in which, incidentally, the minimum price was paid primarily by out-of-state purchasers.

367. 453 U.S. at 618.

368. 453 U.S. at 618.

369. 453 U.S. at $619 ;$ cf. 453 U.S. at 628-29.

370. 453 U.S. at 629.

371. Complete Auto Transit, Inc. v. Brady, 430 U.S. 274 (1977). 
C. "Golden Oldies": Baldwin, Henneford, Eisenberg, Hood, et al.

From the point of view of the essay as a whole, the main object of this section (III.C.) is to show that neither Baldwin v. G.A.F. Seelig, Inc. ${ }^{372}$ nor H.P. Hood \& Sons v. Du Mond ${ }^{373}$ is a balancing case, even though both are favorite sources of modern balancers' rhetoric. But Baldwin cannot be fully understood without understanding Henneford v. Silas Mason Co. ${ }^{374}$ and (to a lesser extent) Milk Control Board v. Eisenberg Farm Products. ${ }^{375}$ So, in the first subsection I shall discuss Baldwin and Henneford; in the second subsection I shall discuss Eisenberg and two later cases, Parker v. Brown ${ }^{376}$ and Cities Service Gas Co. v. Peerless Oil \& Gas Co., ${ }^{377}$ which illustrate the same principle as Eisenberg (as does Commonwealth Edison Co. v. Montana); and in the third subsection I shall discuss Hood.

How to reconcile Baldwin and Henneford is a classic puzzle. The statutes in the two cases have important formal features in common, but one is upheld and the other is struck down. Cardozo writes both opinions (one for a unanimous Court, the other for a seven-man majority) in the space of two years, with no hint that he thinks he has changed his position.

The common view seems to be that Baldwin and Henneford are not reconcilable at all; but that since Cardozo thought the cases were reconcilable and we are unable to understand his explanation, he must have been balancing, even though he does not say so. ${ }^{378}$ Cardozo deserves better than this. In fact, the cases are clearly reconcilable. Furthermore, although Cardozo does not discuss the cases with the greatest possible lucidity, it is clear, once we know what the right analysis is, that Cardozo has the right analysis in mind.

Let us ignore the opinions for the moment, and let us begin with the factual situation of Henneford. Henneford involved the State of Washington's use tax, imposed on goods purchased outside Washington by residents of Washington and then brought into and used within Washington. The use tax was set at the same rate as the state sales tax

372. 294 U.S. 511 (1935).

373. 336 U.S. 525 (1949).

374. 300 U.S. 577 (1937).

375. 306 U.S. 346 (1939).

376. 317 U.S. 341 (1943).

377. 340 U.S. 179 (1950).

378. See, e.g., G. GUNTHER, CONSTITUTIONAL LAW 281 (11th ed. 1985); W. LOCKHART, Y. KAMISAR \& J. ChOPER, CONSTTTUTIONAL LAW 327-28 (6th ed. 1986). 
imposed on goods purchased within Washington; and the use tax was forgiven if a comparable sales tax or use tax had been paid in the state of the actual sale. (This is a schematized version of the facts. I ignore transportation costs, which complicate the analysis without changing it fundamentally; and I have made it sound as if the use tax considered by itself was discriminatory on its face. Actually, the use tax was so drafted as not to be discriminatory on its face. This was wise drafting, but it makes no difference in the end to the proper analysis of the case.)

Considered in itself, the use tax almost certainly had a protectionist purpose. Specifically, it was designed to prevent the diversion of business from Washington retailers, who were subject to the Washington sales tax, to foreign retailers who, if untaxed, would enjoy a competitive advantage as a result of the Washington sales tax. Presumably another purpose of the use tax was to prevent the loss of tax revenue that would be occasioned by the diversion of retail sales to foreign retailers, and this pure revenue purpose would not count as protectionist in my scheme. But it strains credulity to think that the use tax was not motivated in part by solicitude for local retailers. So, the use tax, considered in itself, had a protectionist purpose.

Nonetheless, the use tax was properly upheld. The reason is that it was enacted in a context that makes its technically protectionist purpose unobjectionable.

As we have said, the purpose of the use tax was to prevent a diversion of business away from Washington retailers that would have been caused by the Washington sales tax standing alone. Washington is not trying to give local retailers any advantage. Nor is Washington even trying to remove any disadvantage except the disadvantage that the Washington sales tax itself creates. Surely it is clear intuitively that this merely compensatory or equalizing purpose - this purpose to avoid disfavoring local retailers by having a sales tax - is not objectionable in the way protectionism is objectionable.

We reach the same conclusion, that the Washington use tax is innocent, if we consider our three basic objections to protectionism. (1) The use tax is immune to the concept-of-union objection because Washington's desire not to give foreign retailers a special advantage by adopting a sales tax manifests no hostility to foreign retailers. (2) Because there is no hostility, resentment is unlikely. Nor is retaliation a problem. Henneford allows only compensating use taxes, that is, use taxes imposed by states that have internal sales taxes. A state with no sales tax would have to adopt a sales tax before it could "retaliate" against Washington's use tax with a use tax of its own, and it seems 
unlikely any state would behave so. (Indeed, it would get no advantage from behaving so, since its use tax would only compensate for the bad effects on its retail business of its sales tax.) A state that already has a sales tax may be moved by Washington's example and by the holding in Henneford to add a use tax; but if it does, there is little reason to think of its doing so as "retaliation," since resentment is not likely to be a significant aspect of its motivation. (3) As to efficiency, remember we said protectionism is inefficient because it diverts business away from presumptively low cost producers without seeking any federally cognizable benefit. But the point of Washington's use tax is to prevent a diversion of business that would be caused by the uncompensated sales tax. If any retailers deserve to be regarded as the presumptively low cost producers, it is the retailers who would have the relevant business in the absence of either sales tax or use tax; and the point of the compensating use tax is to see that those retailers are not deprived of business by the sales tax standing alone. (Even the modern welfare economist, versed in second-best analysis, would agree: given the sales tax, the use tax may be a good thing.)

To summarize, there is nothing in our constitutional scheme, and nothing in the idea that protectionism is forbidden, that suggests that if a state imposes a sales tax it must necessarily accept as the price of that imposition some diversion of business from local to out-of-state concerns.

There is much more that could be said about Henneford, quite apart from its relation to Baldwin. But in the interest of getting on with the main business, I relegate further discussion of Henneford itself to an Appendix (at the end of this subsection), which I recommend only to Henneford aficionados and to others who have specific questions or objections concerning what I have said.

Now, why does my analysis of Henneford not apply equally to Baldwin? Here are the facts. New York had a statute, whose constitutionality was unchallenged, imposing a minimum price on purchases of milk from producers in New York. Another statute, the one that was struck down, forbade the sale in New York of milk that had been purchased from out-of-state producers at less than the minimum price for local purchases. This second law could be defended as a mere attempt by New York to preserve the integrity of its scheme for regulating milk prices in New York: having imposed a minimum price to producers for purchases in New York, the state arguably needed to do something to prevent the diversion to out-of-state producers of business that would normally have gone to in-state producers. Why can we not say on behalf of the New York law just what we said on behalf 
of the Washington use tax: "There is nothing in our constitutional scheme ... that suggests that if a state imposes a [minimum price] it must necessarily accept as the price of that imposition some diversion of business from local to out-of-state concerns"?

The answer, in brief, is that while a use tax just exactly neutralizes the diversionary tendency of the sales tax, New York's law forbidding the sale in New York of milk bought elsewhere at a subminimum price threatens to do more than merely neutralize the diversionary tendency of the local minimum price law. (And, unfortunately for states that want to have minimum prices, there probably is no way they can neutralize the diversionary tendency without running into constitutional difficulty by threatening to do more.)

Imagine for the moment that Vermont dairy farmers have some natural competitive advantage over New York dairy farmers - lusher pasturage, say, or a more productive breed of cow. If Vermont farmers had such an advantage, then one effect of the statute invalidated in Baldwin would be to deprive them of the possibility of exploiting it. Even if Vermont farmers were economically in a position to undersell New York dairy farmers, they would be forbidden to do so. So, New York's exclusion of foreign milk bought at subminimum prices could have a protectionist effect beyond merely neutralizing the diversionary tendency of the local minimum price law. It could benefit local dairy farmers by depriving foreign dairy farmers of the chance to exploit an advantage that was not simply a consequence of the enforcement in New York of New York's minimum price scheme.

Now, I do not know whether Vermont farmers had any natural advantage, and I doubt that Cardozo knew when he wrote Baldwin. If Vermont dairy farmers did not have any natural advantage, then the challenged New York statute might indeed have done nothing more than prevent the diversion to Vermont dairies of custom that would have gone to New York dairies except for the minimum price scheme applied to New York purchases. In that case, the statute in Baldwin would have been doing just what the use tax did in Henneford.

Still, the effects of the statute in Baldwin depend on whether or not Vermont dairy farmers have a natural advantage. And therein lies the difference between Baldwin and Henneford. The statute in Baldwin could, under certain circumstances, do more than equalize for the effects of the in-state minimum price; the use tax in Henneford could not under any circumstances do more than equalize for the effects of Washington's sales tax. ${ }^{379}$

379. Others before me have noticed this difference between the Washington use tax and the New York statute. G. GUNTHER, supra note 378, at 281; L. TRIBE, supra note 177, at 359; 
We have not yet established that Baldwin was rightly decided. What we have established is that Henneford was right and that Baldwin is clearly distinguishable. The remaining question about Baldwin is whether the Court should have undertaken to investigate the real comparative position of New York and Vermont dairy farmers and to decide whether New York's exclusion of subminimum price Vermont milk actually did, or was intended to do, more than equalize for the effect of enforcing the minimum price in New York.

The answer to part of this question is clear: The Court should not attempt to evaluate the comparative positions of New York and Vermont farmers or the actual effect of New York's exclusion of subminimum price Vermont milk. There is no adequate reason to involve the courts in such problematic issues, especially since the facts may change from year to year.

It is not so clear that the Court should refuse to consider whether the New York legislature's purpose was limited to neutralizing the diversionary tendency of the local minimum price. This would be a plausible inquiry. Even so, a per se rule against exclusions of subminimum price foreign products, such as Cardozo seems to have adopted, is perfectly comprehensible. There is an undoubted technical protectionist purpose, just as there was in Henneford: there is a direct legislative intention to affect the competitive position of local actors vis-à-vis foreign competitors. It seems reasonable to hold that a state can avoid the prima facie objections to such protectionist purpose if and only if the measures it takes to neutralize the diversionary effect of the local tax or regulatory scheme are such that they self-evidently cannot do more than neutralize. The tax in Henneford passes this test; the statute in Baldwin does not.

Let us now consider Cardozo's opinions in Baldwin and Henneford. These opinions ought to be read together, and together they illustrate perfectly the truth that sometimes the best way to figure out what an opinion (or series of opinions) is saying is to figure out first what it should be saying and then to see whether it can be read as saying that. Judges often grasp intuitively more than they have the ability, or the time, or the patience, to explain. There is overwhelming evidence, once we open our eyes to it, that Cardozo saw these cases just as we have analyzed them.

First, both Baldwin and Henneford contain many references to

Brown, supra note 1 , at 235. But having noticed the difference, these authors miss its significance, which only appears clearly in the context of an anti-protectionist analysis. (See the immediate continuation in the text, and note also the paragraph of text at note 389 infra on Cardozo's claim that Baldwin and Henneford are very different.) 
customs barriers or tariffs, which establish the basic theme as protectionism. Thus Cardozo says in Baldwin that if New York can apply its minimum price to milk produced in Vermont, then it can "set a barrier to traffic between one state and another as effective as if customs duties, equal to the price differential, had been laid upon the [milk]."380 Later on, referring to state regulations like New York's: "Restrictions so contrived are an unreasonable clog upon the mobility of commerce. They set up what is equivalent to a rampart of customs duties designed to neutralize advantages belonging to the place of origin."381 In Henneford, of course, the point is how unlike a tariff Washington's use tax is. Cardozo emphasizes repeatedly that Washington's scheme is nondiscriminatory ${ }^{382}$ and that it lacks "any sem. blance of inequality or prejudice."383 Cardozo devotes a long paragraph to explaining why the scheme can not be "stigmatized as equivalent to a protective tariff." 384

As to the specific reasons why New York's statute is like a protective tariff and Washington's is not, Cardozo refers repeatedly in Baldwin to the tendency of the New York law to "neutralize advantages belonging to the place of origin."385 And on the question whether Vermont farmers really have any independently existing advantage: "There is neither evidence nor presumption that the same minimum prices established by order of the Board for producers in New York are necessary also [to guarantee the quality of the milk] for producers in Vermont."386 In Henneford the contrasting theme is that Washington's use tax merely neutralizes the diversionary tendency of its sales tax. "Equality is the theme that runs through all the sections of the statute."387 A statute will not be viewed as the functional equivalent of a tariff "when equality and not preference is the end to be achieved."388

380. 294 U.S. at 521.

381. 294 U.S. at 527.

382. E.g., 300 U.S. at $582,583,584-85$.

383. 300 U.S. at 587.

384. 300 U.S. at 586-87.

385. 294 U.S. at 527,528 (refers to neutralizing economic advantages belonging to the place of origin).

386. 294 U.S. at 524.

387. 300 U.S. at 583.

388. 300 U.S. at 586; see also 300 U.S. at 581, 584. Notice that Cardozo must be using "preference" here in the way I explained in section I.B. that I would use it. (And he is using "equality" as the opposite of "preference".) This must be the case because otherwise the attempt to distinguish Baldwin would make no sense. If "preference" meant preference in what I called the absolute-advantage sense (and if "equality" were the opposite of that), then it would be as true of the statute in Baldwin as of the use tax in Henneford that equality and not preference was the end to be achieved. The statute in Baldwin aims at no absolute advantage. (For a slightly 
It is noteworthy also that when Cardozo discusses Baldwin in his opinion in Henneford, he says "[that] case is far apart from this one." 389 And, "What Washington is saying to sellers beyond her borders is something very different [from what New York was saying]." 390 To anyone who is tempted to think Cardozo is balancing, these assertions that Baldwin and Henneford are very different must be incomprehensible. The balancer cannot really see any difference at all between Baldwin and Henneford; he has nothing like enough facts to say whether they are different or not. But still (the balancer thinks), if Cardozo is determined to decide the cases differently, would not the honest and decent course be to admit that the cases are really very much alike, but to claim there is a subtle line, barely discernible, that the cases fall just on opposite sides of? No. Cardozo was looking at the cases as possible instances of protectionism, and from that perspective we have seen that they are very different, as Cardozo says.

Turning to evidence that might be adduced against my reading of Cardozo's opinions: At one point in Henneford Cardozo seems to say that he is not concerned with legislative motive, ${ }^{391}$ whereas I suggest that protectionism is the central theme and that protectionism is a matter of motive. In context, what Cardozo is saying when he impugns the significance of motive is simply that a motive to protect local retailers against the disadvantage that would flow from a sales tax standing alone does not amount to protectionism. We have already seen why he is right about that. The same thought leads Cardozo to continue: "Catch words and labels, such as the words 'protective tariff,' are subject to the dangers that lurk in metaphors and symbols, and must be watched with circumspection lest they put us off our guard." ${ }^{392}$ Cardozo is not here turning away from the central metaphor of his own opinions in Baldwin and Henneford. He is recommending circumspection, just as he says.

There is a passage in Baldwin that Justice Frankfurter quotes in his dissent in Hood as evidence that Cardozo was balancing. Thus Frankfurter: "[I]t is the essential teaching of [Baldwin] that "considerations of degree' determine the line of decision between what a State may and what a State may not regulate, [when interstate commerce is in-

more expansive discussion of this point, see the first few paragraphs of the Appendix at the end of this subsection.)

389. 300 U.S. at 585.

390. 300 U.S. at 586 .

391. 300 U.S. at 586.

392. 300 U.S. at 586 . 
volved]."393 What Cardozo actually said involved "considerations of degree" was distinguishing between "direct and indirect restraints of commerce." 394 But of course we know, and Frankfurter knew, and Cardozo knew (even if he did not say it here) that the real question was not well rendered by the terms "direct" and "indirect." 395 What is the question, then, to which Cardozo is saying considerations of degree are relevant? Frankfurter thought it must be the question how some balancing process turns out. That shows the weakness of Frankfurter's imagination. The question Cardozo was asking, with respect to any challenged state statute, was rather: How much is it like a protective tariff? That is not a balancing question, but it can be a matter of degree, just as Cardozo suggests. On the other hand, Cardozo thought some distinctions under this standard were easy, like the distinction between Baldwin and Henneford.

Finally, there are the famous passages in Baldwin about the glories of economic union, which commentators have habitually overread. Cardozo writes: "[The Constitution] was framed upon the theory that the peoples of the several states must sink or swim together, and that in the long run prosperity and salvation are in union and not division."396 And: "What is ultimate is the principle that one state in its dealings with another may not place itself in a position of economic isolation." 397 These passages can be read and, in context, obviously should be read as rhetorically inflated reminders of the evil of protectionism. Nothing more.

\section{Appendix: More About Henneford}

This Appendix, as I have noted before, is for readers who have a special interest in Henneford or who have specific objections to my treatment that I have not yet dealt with. Other readers will want to skip over the Appendix and go immediately to subsection III.C.2. (on Eisenberg and similar cases).

(1) The result in Henneford has been criticized vigorously by Ernest Brown ${ }^{398}$ and Walter Hellerstein. ${ }^{399}$ Both Brown and Hellerstein complain that the Court has failed to see that the issue in Henneford is

393. H.P. Hood \& Sons v. Du Mond, 336 U.S. 525, 569 (1949) (Frankfurter, J., dissenting) (quoting 294 U.S. at 525).

394. 294 U.S. at 525.

395. Cf. Carter v. Carter Coal Co., 298 U.S. 238, $327-28$ (1936) (Cardozo, J., dissenting) (criticizing "direct/indirect" test as criterion for Congress' commerce power).

396. 294 U.S. at 523.

397. 294 U.S. at 527.

398. Brown, supra note 1 , at 234-36.

399. Hellerstein, supra note 8 , at 461-62; $c f$. Hellerstein's comments in the symposium dis- 
"protection - not preference but protection." 400 Now, I claim that protectionism essentially involves preference, and that once we have decided there is no preference, we have disposed of the issue of protectionism. Why do Brown and Hellerstein disagree?

One possibility is that they overlook the ambiguity of the word "preference," which I have discussed previously. ${ }^{401}$ I fully agree with Brown and Hellerstein that it is not an adequate defense of the use tax in Henneford to point out that Washington retailers receive no preference in the sense that even with the use tax in place they enjoy no absolute competitive advantage over Oregon retailers. That is a weak sense in which the use tax creates no preference; but that sense is not enough to validate the tax in Henneford since exactly the same thing could be said in defense of the New York milk price scheme in Baldwin. There is, however, a stronger sense in which the Washington use tax involves no preference: there is no reason at all to think that the use tax is motivated by preference for local interests as such over foreign interests. That cannot be said about the scheme in Baldwin (for reasons I have elaborated in the discussion of Baldwin); and in fact the claim that there is no preference in this sense does entail that there is no protectionism.

I do not mean to insist that Brown and Hellerstein say what they say about the issue being "protection - not preference" only because they overlook the ambiguity of "preference." That is probably not the complete explanation. They probably also believe that there are constitutional objections to some behavior which they would call protectionism but which falls outside my definition of protectionism. I shall get to that in (2) and (3) below. However, their view does seem to be colored by inattention to the subtleties of "preference." Evidence for that is that they both treat Henneford as indistinguishable from Baldwin by any plausible reasoning, whereas I have surely shown that Henneford is different from Baldwin even if one thinks there is still adequate reason to forbid the law in Henneford.

(2) Brown asks rhetorically:

Should one state in a federal system be able to raise its price levels, isolate itself and protect its markets from the outside price competition thereby stimulated? Or does the federal system demand at least that degree of economic unity which would require that consumers and buyers

cussion reported in REgULATION, FEDERALISM, AND INTERSTATE COMMERCE, supra note 3, at 125.

400. The quote is from Brown, supra note 1 , at 235 . Hellerstein echoes the thought in his article, supra note 8 , at 462 .

401. Section I.B., text preceding note 13 supra. 
within the state have some measure of access to a free market outside?402

Now, Brown's questions are not well formulated to help one distinguish between Baldwin and Henneford, and the rhetorical force of the questions is much more apposite to Baldwin. With regard to Henneford, there is no question of the state "isolating itself," nor is there any question of the state protecting its markets from outside competition except in the very weak sense that by imposing the use tax the state avoids the competitive distortion (of consumers' choices between retailers) that an uncompensated sales tax would cause. (The scheme in Baldwin, we have seen, might do more.) I have argued that there is nothing in the Constitution that prevents the state from trying to avoid that competitive distortion. On the face of it, Brown's appeals to "the federal system" and to "economic unity" seem only to mask a belief that taxes are presumptively bad and that in order to discipline states that want to interfere with a "free market" by imposing taxes we must constitutionally guarantee opportunities for tax-avoidance. But the Constitution embodies no presumption that taxes are bad.

(3) Hellerstein, who quotes Brown's complaint approvingly, ${ }^{403}$ also adumbrates a more sophisticated version of the complaint. Hellerstein suggests that the decision in Henneford inappropriately interferes with interstate tax competition. 404 Now, I see no reason to think that protecting tax competition is a constitutional value in itself (though of course many features of our federal system combine to guarantee a good measure of possible tax competition). But even if protecting tax competition were a constitutional value, it would provide no argument against the result in Henneford.

The primary point is this: If we changed the result in Henneford, the state would be unable to prevent free-riding. Residents of Washington living near the Oregon border would be able to divert their retail purchases to Oregon (thereby avoiding the Washington sales tax), but they would give up none of the benefits purchased with the sales tax revenues that Washington would still get from people unable to avoid the tax. Such free-riding is not an aspect of competition. Free-riding is antithetical to competition - at least if we value competition as the high road to economic efficiency, which is how most people now value it. Free-riding is a way of externalizing costs.

If it were the case that the benefits of programs supported by the

402. Brown, supra note 1 , at 234.

403. Hellerstein, supra note 8, at 462; also in Hellerstein's symposium comments in REGULATION, FEDERALISM, AND INTERSTATE COMMERCE, supra note 3, at 125.

404. Hellerstein's symposium comments in REgulation, FEDERALISM, AND INTERSTATE COMMERCE, supra note 3, at 124-25. 
sales tax were distributed to people in proportion to their actual payment of the tax, then the rule in Henneford would interfere with tax competition of a nonstandard sort (nonstandard because what would be in issue is the location, not of businesses or households, but of particular transactions). Washington's use tax would deny Washington residents the choice they would otherwise have between (on the one hand) paying the sales tax and getting the benefit or (on the other hand) avoiding the sales tax by buying in Oregon and forgoing the benefit. But the benefits of programs supported by the sales tax are not distributed in proportion to the beneficiaries' payment of the tax, and there is no constitutional preference for schemes in which the benefits are distributed that way. Given those facts, the Washington use tax does not prevent tax competition; it prevents free-riding. And the rule in Henneford, which allows the use tax, is sensible.

Notice that the rule in Henneford also does not interfere with tax competition of more standard sorts in connection with the sales tax. If Oregon has no sales tax, then despite Washington's use tax retail businesses deciding where to locate will still have reason to prefer Oregon to Washington, since most of an Oregon-based retailer's dealings will be with non-Washingtonians and will be unaffected by the Washington use tax. Similarly, individuals deciding where to reside will choose between Washington and Oregon partly on the basis of their judgment about whether the benefits they would get as citizens of Washington would justify the extra taxes they would pay. (I speak theoretically. Hellerstein admits that it is not clear how much difference any of this makes in practice. ${ }^{405}$ But if tax competition matters, Henneford allows it.)

In fact, the rule in Henneford has a positive effect on tax competition with regard to these decisions about where to locate a business or a home. For one thing, it expands the range of legal schemes a state may offer to its residents. If Henneford had been decided differently, a state would be limited to two alternatives. It could have no sales tax, or it could have an uncompensated sales tax (that is, a sales tax with no use tax). As it is, the state can do either of those things, but it has a third alternative also, namely, a compensated sales tax (a sales tax plus a use tax). And if the uncompensated sales tax invites free-riding, it may be that the compensated sales tax is really the only fair competitor for the no-sales-tax alternative in any event.

One last point in this connection. If Henneford had been decided differently and compensating use taxes were forbidden, then sales 
taxes would be to some extent less attractive, because of the inequity of free-riding, the damage to local retailers, and the revenue loss. There would be some pressure on states to shift toward other sorts of taxes where avoidance is more difficult, such as real property taxes. But there seems to be no adequate reason to push states toward those kinds of taxes which are naturally hard to avoid instead of allowing states to choose the bases of taxation on other considerations more relevant to sound social policy and then to prevent avoidance by such (nonprotectionist) means as compensating use taxes.

What remains to be discussed is a series of shorter, unconnected points.

(4) Although I think Henneford was rightly decided, I make no claim that the Court has also decided rightly all the subsequent cases on when a seller may be required to collect a compensating use tax. ${ }^{406}$ For example, I have doubts about the correctness of National Geographic Society v. California Board of Equalization, ${ }^{407}$ which may allow the burdening of interstate commerce as such by the imposition of excessive administrative requirements on foreign companies with minimal in-state contacts. ${ }^{408}$

(5) I recognize that a compensating use tax could be part of a genuinely protectionist scheme, if, for example, a state that made furniture mainly out of oak imposed a sales tax and a compensating use tax only on furniture made out of maple. The fact that the use tax on maple furniture "merely" compensated for the sales tax on maple furniture (insofar as we consider choices about where to buy by consumers committed to maple furniture) would not make up for the fact that the whole scheme for taxing maple furniture was adopted to favor local oak furniture, if that was in fact the purpose of the scheme. Here, as elsewhere, purpose is the crucial question.

(6) Some reader may wonder how my view of Henneford fits with my thesis that a law is unconstitutional if "any feature" of the law is protectionist. 409 The answer is that the "any feature" test does not direct our attention to "any feature, considered in isolation" but rather to "any feature, considered as part of the overall scheme." In Henneford, the use tax may look protectionist considered in isolation, but that appearance dissolves completely when we consider the use tax as

406. Cf. Hellerstein, supra note 8 , at $449-50$.

407. 430 U.S. 551 (1977).

408. Cf. the discussion of Allenberg Cotton Co. v. Pittman, 419 U.S. 20 (1974), in section II.F. supra, text at notes 184-87.

409. Cf. subsection II.A.1. supra, the end of the discussion of the revenue-tariff and analogous laws. 
part of the scheme which includes the sales tax as well. In the scheme as a whole there is no element of local preference. In contrast, if we consider the revenue-tariff (the prototype case for the "any feature" rule), the fact that the primary purpose is to raise revenue does not in any way eliminate the local preference embodied in the decision to raise revenue disproportionately at the expense of foreign producers.

(7) The reader might wonder whether, in the absence of a local sales tax, Washington could adopt a use tax applicable only to imported goods and could defend the use tax on the ground that local retailers pay higher property taxes than foreign retailers, or that foreign retailers pay lower payroll taxes than their local counterparts. My own answer would be, No. In this hypothetical, just as in Baldwin, we would have a conceded purpose to improve the competitive position of local actors, and it would be far from self-evident that the use tax did no more than neutralize the other tax differentials. (The Court's view on "equalizing" taxes may be more generous than mine, though I doubt it. It would take more effort than I am prepared to make here to discuss the Court's view adequately, because the issue of equalization is intertwined in the opinions with other issues about purpose that the Court has not been clear on.)

(8) Finally, the reader might wonder whether North Carolina could have justified the statute struck down in Hunt v. Washington State Apple Advertising Commission ${ }^{410}$ by claiming that the ban on foreign state apple grades merely equalized for North Carolina's decision not to have any state grading system of its own. The answer is clearly, No. As in Baldwin, there would be a significant danger that the supposed equalization in fact prevented foreign producers from exploiting advantages which existed quite independently of North Carolina's decision not to have a grading scheme. Chief Justice Burger seemed to recognize this possibility implicitly when he said the North Carolina statute had a "leveling effect which insidiously operates to the advantage of local apple producers." 411

\section{2}

Milk Control Board v. Eisenberg Farm Products ${ }^{412}$ involved Pennsylvania's minimum price for milk producers. The question was whether the minimum price law could be applied to purchases of milk for shipment out-of-state. In a brief and unilluminating opinion by

410. 432 U.S. 333 (1977).

411. 432 U.S. at 351.

412. 306 U.S. 346 (1939). 
Justice Roberts, the Court held that it could. Since Eisenberg was decided just four years after Baldwin, the question naturally arises: Why can Pennsylvania apply its minimum price to milk purchased in Pennsylvania for shipment elsewhere, while New York cannot apply its minimum price to milk purchased elsewhere for shipment into New York?

There are two standard explanations for the result in Eisenberg. One explanation is that only about ten percent of the milk to which Pennsylvania's minimum price applied was shipped out-of-state. It is unclear whether there is even a factual difference here between Eisenberg and Baldwin. Cardozo does not seem to care greatly in Baldwin how much of New York's milk comes from out-of-state; all he tells us is that thirty percent of the milk for the metropolitan area of New York City comes from out-of-state. ${ }^{413}$ The figure for the state as a whole is probably lower. Whatever we make of that, two later cases suggest that such percentages are not determinative. In Parker $v$. Brown the Court upheld California's marketing scheme for raisins, which in effect included a minimum price regulation, even though ninety percent of the raisins were shipped out-of-state. ${ }^{414}$ Similarly, in Cities Service Gas Co. v. Peerless Oil \& Gas Co. the Court upheld Oklahoma's minimum wellhead price on natural gas even though ninety percent of the gas went out-of-state. ${ }^{415}$ (Of course, there could be alternative explanations for Parker and Peerless. More on that presently.)

The other standard explanation of why Eisenberg is consistent with Baldwin is that Pennsylvania is regulating only the price paid to producers in Pennsylvania, while New York is trying to regulate the price paid to producers in Vermont. In other words, the New York statute is an attempt to legislate extraterritorially, while the Pennsylvania statute is not. But this will not do. In the first place, all New York regulates directly is sales in New York. New York does not say Vermont producers must be paid the minimum price; it says only that if they have not been paid the minimum price, the milk may not be resold in New York. Furthermore, New York's only ultimate concern is the effects in New York of subminimum price milk from beyond its borders.

There is one limited sense in which we might say New York's law is extraterritorial: the permissibility of certain transactions in New

413. 294 U.S. at 519.

414. 317 U.S. 341,345 (1943).

415. 340 U.S. 179, 181 (1950). 
York is made to depend explicitly on the terms of certain other transactions in Vermont. But the use tax upheld in Henneford was extraterritorial in that way. Because Washington's use tax was forgiven to the extent a sales tax had already been paid elsewhere, liability for the use tax (which was levied nominally on an in-state event, the use of the goods in Washington) depended on an aspect of the sale elsewhere. Henneford makes it clear that Baldwin is not about extraterritoriality, so the absence of extraterritoriality cannot be what distinguishes Eisenberg.

The proper explanation of Eisenberg is simple enough. The minimum price law, even as applied to milk for out-of-state shipment, is not in any way protectionist. The Pennsylvania statute benefits Pennsylvania milk producers at the expense of out-of-state distributors and consumers; but producers are not in competition with distributors and consumers. And in-state distributors and consumers pay the same higher prices that the out-of-staters pay. In short, there is no protectionist effect and a fortiori (as a practical matter, not as a logical matter) no protectionist purpose.

The reader might object that the statute affects local and foreign producers differently. Pennsylvania producers are benefited by the minimum price; foreign producers are not, since it does not apply to them. This is true (more or less), but irrelevant. The Pennsylvania law may benefit local producers, but not by improving their competitive position vis-à-vis their foreign competitors. No business will move from a foreign milk producer to a local producer as a result of the local producer's being guaranteed a minimum price. If anything, the minimum price will divert business away from the local producers; it will damage their competitive position. (This is why the foreign producers may actually benefit from the law themselves.) In any event, insofar as local and foreign producers are differently treated, there is no reason to think the difference results from a desire of the Pennsylvania legislature to prefer the locals. For all we know, Pennsylvania believes there ought to be minimum prices for the benefit of all producers everywhere - for all we know, it believes there should be a minimum price to producers in Wisconsin on milk to be consumed in Wisconsin (which will do nothing for Pennsylvania producers). But Pennsylvania cannot effect its vision for the milk producers of Wisconsin, only for those of Pennsylvania. That is a genuine matter of territoriality.

What of Roberts' opinion in Eisenberg? As I have said, the opinion is brief and unilluminating; but for what it is worth, it shows more indication of being concerned with anti-protectionism than with bal- 
ancing. Once the preliminaries are done with, the focused discussion of the case occupies a bare page and a half. Most of this is taken up with argument that the activity regulated is "essentially local"416 and that the effect on interstate commerce is "incidental." 417 Baldwin is discussed only in the last sentence of the opinion (ignoring the sentence decreeing reversal and remand); but the last sentence can reasonably be taken to reflect what Roberts sees as important:

In Baldwin ... this court condemned an enactment aimed solely at interstate commerce attempting to affect and regulate the price to be paid for milk in a sister state, and we indicated that the attempt amounted in effect to a tariff barrier set up against milk imported into the enacting state. 418

Roberts first appears to suggest that the vice of the statute in Baldwin was extraterritoriality. But we know that is not the true story. Roberts' further and final claim is that the statute in Baldwin amounted to a tariff barrier. We have seen that Roberts is right about that. An unavoidable implication of Roberts' claim about the statute in Baldwin is that the statute in Eisenberg does not amount to a tariff. We have seen that Roberts is right about that too: tariffs are instruments of protectionism and the Pennsylvania minimum price law is not protectionist. In sum, Roberts' opinion is at least as much an anti-protectionist opinion as it is anything else.

If the statute in Eisenberg has no protectionist effect, then neither do the minimum price regulations in Parker v. Brown 419 and Cities Service Gas Co. v. Peerless Oil \& Gas Co. 420 So these cases also could have been decided simply on the ground that they involved no protectionism. Is that how they were decided?

The opinion in Parker is normally regarded as a balancing opinion, and I concede (for once) that it may be rightly so regarded. The opinion is written by Chief Justice Stone, who may have been a genuine balancer. What is normally taken to have determined the result of the case is the clear federal policy in favor of California's raisin marketing scheme, and Stone discusses the federal support for the California scheme at considerable length. ${ }^{421}$

Assuming Stone is balancing, I have two further observations. First, my present anti-balancing thesis, as I have said, is about the

416. 306 U.S. at 352.

417. 306 U.S. at 353.

418. 306 U.S. at 353.

419. 317 U.S. 341 (1943).

420. 340 U.S. 179 (1950).

421. 317 U.S. at $364-68$. 
practice of the Court, not about the practice of every individual Justice. One balancing opinion does not make a judicial tradition. Second, even if Parker involves balancing of a sort, a case that relies so heavily on federal policy as expressed in congressional and administrative behavior is not much of a precedent for the Court's striking out on its own in a balancing mode when Congress and the agencies have been silent. ${ }^{422}$

Justice Clark writes for the Court in Peerless. He speculates about a federal policy in favor of gas conservation, ${ }^{423}$ but he has far less to work with than Stone did in Parker, and he sounds much less like a balancer. He distinguishes H.P. Hood \& Sons v. Du Mond ${ }^{424}$ on the ground that the regulation there discriminated.425 His explanation of why the Oklahoma regulation in Peerless does not discriminate has the simplicity and straightforwardness of Marshall discussing the Montana coal severance tax. ${ }^{426}$ As Clark says: "There is no [discrimination] here. The price regulation applies to all gas taken from the field, whether destined for interstate or intrastate consumers." 427 In the paragraph where Clark comes closest to balancing the effects of the Oklahoma regulation, he anticipates the "clearly excessive" aspect of the Pike test: "[W] cannot say that there is a clear national interest so harmed that the state price-fixing orders here employed fall within the ban of the Commerce Clause."428 After citing Parker and Eisenberg, and thus locating Peerless in the right line of cases, he continues (and concludes): "Nor is it for us to consider whether Oklahoma's unilateral efforts to conserve gas will be fully effective."429 There is not much balancing going on here.

If we now throw in Commonwealth Edison Co. v. Montana, ${ }^{430}$ to which I have just alluded, we have four essentially similar cases spanning forty years. (For some purposes, of course, a severance tax is quite different from a minimum price; but for present purposes it is very much the same.) All four cases can be straightforwardly decided by the rule that where there is no protectionist effect (and no national interest present of the sort that might appear in a non-movement-of-

422. Compare my remarks in section III.D. at notes 522-23 infra, on the relation between the balancing and preemption theories in Edgar v. MITE Corp., 457 U.S. 624 (1982).

423. 340 U.S. at 187-88.

424. 336 U.S. 525 (1949).

425. 340 U.S. at 188 .

426. See subsection III.B.4. supra.

427. 340 U.S. at 188 .

428. 340 U.S. at 188 .

429. 340 U.S. at 188.

430. 453 U.S. 609 (1981). 
goods case), the statute is to be upheld. That, I suggest, is the rule these cases stand for. ${ }^{431}$

The last old case I shall discuss is H.P. Hood \& Sons v. Du Mond. ${ }^{432}$ Hood was a Massachusetts corporation that bought milk from dairy farmers in New York State for distribution in Boston. Hood had long operated three milk receiving depots in New York. It now sought licensing for a fourth depot. The New York Commissioner of Agriculture and Markets, operating under a statutory grant of authority, refused to license the new depot, on the grounds (1) that the milk producers in the area of Hood's proposed new depot were already adequately served, (2) that competing milk purchasers might lose producers to Hood's new depot and suffer a rise in handling costs, (3) that Hood's new depot might cause milk shortages in Troy, New York, and, in sum, (4) that Hood's new depot would tend to cause "destructive competition," and would not be in the public interest. ${ }^{433}$ The Court, speaking through Justice Jackson, held that the denial of the license was unconstitutional. Justices Black and Frankfurter wrote the two dissenting opinions.

I am not certain Hood was correctly decided or, if it was, what is the best analysis. (It is worth noticing that Hood was decided by a five-to-four vote. That makes Hood unique among major movementof-goods cases, which are typically decided by lopsided divisions if not unanimously.) The main uncertainty is whether the New York Commissioner was motivated by protectionist purpose when he refused to license Hood's new depot. Both Black and Frankfurter seem to think the Commissioner was engaged in making perfectly evenhanded decisions, free of any local preference, aimed at protecting all producers and consumers local or foreign from disruption of existing patterns of

431. Of course, the absence of protectionist effect is being treated as all but conclusive evidence of the absence of protectionist purpose, which is what is really determinative.

It should be noted that these four cases do not show that the Court is enforcing the antiprotectionism principle proper as opposed to the no-singling-out principle (discussed in section II.D. supra). Not only is there no advantaging of locals vis-à-vis foreign competitors in these cases, there is no advantaging of locals vis-à-vis any foreigners who are similarly situated. So even under the no-singling-out principle the results would be the same. On the other hand, these cases are strong evidence that the Court has not adopted the no-hostile-treatment principle not because there is hostile treatment which the Court condones, but because the Court does not discuss the possibility. And similarly, these cases are strong evidence that the Court has not adopted Carolene Products-based private interest balancing.

432. 336 U.S. 525 (1949).

433. 336 U.S. at 529. 
milk distribution. ${ }^{434}$ And Jackson never denies this possibility specifcally and unambiguously.

Jackson repeatedly and explicitly condemns the denial of facilities to Hood by reference to the purpose of the denial, ${ }^{435}$ and for myself I have little doubt that he thought the Commissioner was motivated by local preference. But it must be admitted that all of Jackson's condemnations of the purpose of the denial could just possibly be read as saying that even a neutral anti-competitive purpose (that is, a purpose to discourage competition untainted by any form of local preference) is unconstitutional when, in a particular case, it operates to disadvantage a foreigner vis-à-vis a local competitor. ${ }^{436}$ If this is what Jackson is saying, then he appears to be going beyond anti-protectionism as I have defined it; but even that appearance is probably deceptive, for reasons set out in the next paragraph.

Even if the Commissioner had no protectionist purpose, the case may have been properly decided, under a sort of "void for vagueness" approach as suggested by Vincent Blasi. ${ }^{437}$ If administrative officials are given substantial discretion to decide on grounds of "public convenience" or on grounds of "suppressing destructive competition" cases in which the economic interests of local actors come into headto-head conflict with the interests of their foreign competitors, the danger of improperly motivated decision of such cases is obviously very great. Perhaps we should have a strong presumption against the regularity of such decisions, which the Commissioner in this case was not able to overcome. Or perhaps administrative schemes creating such discretion should just be flatly unconstitutional. If Jackson was not certain the New York Commissioner's purpose was protectionist, he (Jackson) almost certainly had some such analysis as this in mind as an implicit backup theory. ${ }^{438}$

434. See 336 U.S. at 547, 549 (Black, J., dissenting); 336 U.S. at 575 (Frankfurter, J., dissenting).

435. 336 U.S. at 526 ("the grounds of denial"), 530 ("avowed purpose"), 539 ("to protect"), 542 ("upon the ... grounds"), 545 ("for the benefit of").

436. Examples of the passages about which I am making this generous concession may be found quoted in the text at notes 439,440 , \& 441 infra.

437. See Blasi, supra note 1 , at 195.

438. Whatever Jackson had in mind, two later cases in which the states prevail show that the Court as a whole has not adopted an absolute ban on schemes creating substantial administrative discretion to favor locals over foreign competitors. See Tuscan Dairy Farms, Inc. v. Barber, 439 U.S. 1040, dismissing appeal from 45 N.Y.2d 215, 380 N.E.2d 179, 408 N.Y.Supp. 2d 348, (1978); Panhandle E. Pipe Line Co. v. Michigan Pub. Serv. Commn., 341 U.S. 329 (1951). Both of these cases, however, are consistent with the claim that the Court is engaged in motive review and even with the claim that there is a significant presumption against the regularity of discretionary anti-competitive decisions by state officials which disadvantage foreigners. In Panhandle the order which was upheld forbade local gas sales by a foreign pipeline company without a certificate of public convenience and necessity. The foreign pipeline company had not even ap- 
One thing is absolutely clear: whatever the proper result in Hood, and whatever the best analysis, Jackson's ultimate concern is with protectionism, conceived of as involving purposeful local preference, throughout. Let me elaborate.

I think many readers of Hood have taken from the dissents the claim that the Commissioner's purpose was innocent (or may have been innocent) and have concluded that the case could not be about purposeful protectionism. But the dissenters do not speak for Jackson. It is odd that Jackson does not respond directly to the dissenters' suggestions about the Commissioner's possibly neutral purpose; I shall suggest some possible reasons for that omission further on. Even so, if Jackson never flatly and unambiguously says the Commissioner's purpose is protectionist, he also never says it is not protectionist or even suggests by any positive word that he thinks it might not be protectionist.

No one reading Jackson's opinion for the first time, without benefit of the accumulated commentary and without having peeked at the dissents, would doubt for a moment that what Jackson was worried about, and what he thought he saw in the Commissioner's act, was old-fashioned protectionism, pure and simple. When, after reading Jackson, we read the dissents, they may give us pause. If we go back and reread Jackson's opinion to check our first impression of it, we may think it possible that Jackson was not absolutely convinced of the Commissioner's bad motive and was relying to some extent on a presumption or a "void for vagueness" analysis. But we find nothing to disturb our impression that purposeful protectionism is what Jackson sees as the problem.

Let us have some specifics. Here is the very first sentence of Jackson's opinion: "This case concerns the power of the State of New York to deny additional facilities to acquire and ship milk in interstate commerce where the grounds of denial are that such limitation upon interstate business will protect and advance local economic interests." 439 Consider the specific reference to purpose ("the grounds of denial"), the occurrence of the word "protect," and the pointed contrast between "interstate" business and "local" economic interests. Surely Jackson thinks he is confronting traditional, purposeful protec-

plied for a certificate. So all the Court held, in effect, was that the foreign pipeline company could be required to apply. In Tuscan Dairy Farms, decided under the same statutory scheme involved in Hood, there was much evidence that even though Tuscan Dairy Farms was a New Jersey company, the Commissioner who denied Tuscan Dairy Farms a license to expand its sales in New York was motivated by a neutral purpose to avoid destructive competition and not by local preference.

439. 336 U.S. at 526. 
tionism. Admittedly the sentence could be made more explicit, if there were any apparent need for greater explicitness; but Jackson could easily believe he has spoken clearly enough.

Or consider the practices to which Jackson assimilates the New York Commissioner's order in the following passage:

We need only consider the consequences if each of the few states that produce copper, lead, high-grade iron ore, timber, cotton, oil or gas should decree that industries located in that state shall have priority. What fantastic rivalries and dislocations and reprisals would ensue if such practices were begun! Or suppose that the field of discrimination and retaliation be industry. May Michigan provide that automobiles cannot be taken out of that State until local dealers' demands are fully met? Would she not have every argument in the favor of such a statute that can be offered in support of New York's limiting sales of milk for out-of-state shipment to protect the economic interests of her competing dealers and local consumers? Could Ohio then pounce upon the rubbertire industry, on which she has a substantial grip, to retaliate for Michigan's auto monopoly? 440

Jackson also discusses Eisenberg and Baldwin. He says that Hood, unlike Eisenberg, involves restrictions "imposed for the avowed purpose and with the practical effect of curtailing the volume of interstate commerce to aid local economic interests ...."441 Not only does this sound like a charge of protectionism; but also the attempt to distinguish Eisenberg fails unless we read Jackson as talking about a purpose to protect local economic interests as such, that is, as local. The regulatory scheme in Eisenberg protected interests that were both local and economic. But there was no evidence it protected them merely because they were local. There was no discrimination, even in effect, between locals and foreigners who were in competition with each other.

(Because Jackson talks about "curtailing the volume of interstate commerce," someone might think the distinction he is drawing between Hood and Eisenberg has to do with the quantity of goods moving across state lines. The New York Commissioner's order diminished the flow of milk across state lines; the Pennsylvania minimum price did not, at least not directly. But we know that cannot be the point. We know the flow of goods as such does not matter in theory; ${ }^{442}$ and to see that the Court does not care about the flow of goods as such, we have only to compare Pike, in which an order with no effect on the ultimate interstate flow of cantaloupes was struck

440. 336 U.S. at 538-39.

441. 336 U.S. at 530-31.

442. See section II.E. supra. 
down, with Clover Leaf, in which a statute eliminating the flow into Minnesota of nonreturnable plastic milk containers was upheld. There is no reason to think Jackson would have disagreed with the result in either Pike or Clover Leaf.)

With regard to Baldwin, Jackson obviously thinks Hood and Baldwin are essentially analogous, even though one involves a clog on exports of milk and the other a clog on imports. ${ }^{443}$ We have seen that Baldwin is about protectionism. There is nothing in Jackson's opinion which, properly understood, suggests that he has any different view of Baldwin.

There must of course be something in Jackson's opinion that the balancers point to. What is there? One sort of passage that has misled readers into thinking Jackson has more on his mind than protectionism occurs in the discussion of Baldwin. Thus: "In neither case [Baldwin nor Hood] is the measure supported by health or safety considerations but solely by protection of local economic interests ...."444 Five times in five pages Jackson appears to draw a distinction between considerations of health or safety and merely economic considerations; 445 and many readers have seen in this a direction for assigning weights to various interests preliminary to balancing them. But whenever Jackson distinguishes between laws passed for health or safety reasons and laws promoting economic interests, he can be read as merely characterizing in a rough and ready way the distinction between laws that are not protectionist and those that are. Laws that protect health or safety normally are not protectionist. (Every now and then a law partly so grounded or arguably so grounded is protectionist, and it is struck down, witness City of Philadelphia v. New Jersey ${ }^{446}$ and Dean Milk.) Laws that promote economic interests often are protectionist. (But when an economically motivated law is not protectionist, it is upheld, witness Eisenberg and Parker v. Brown.) Consideration of the complete passage in which Jackson draws this distinction makes it clear that protectionism is the evil that is feared.

The other aspect of Jackson's opinion that balancers have seized on is some purple prose reminiscent of Cardozo's opinion in Baldwin. Here are some famous quotations:

This principle that our economic unit is the Nation, which alone has the gamut of powers necessary to control of the economy ... has as its

443. See 336 U.S. at 531, 535.

444. 336 U.S. at 531.

445. 336 U.S. at 531, 532 (twice), 533, 535.

446. 437 U.S. 617 (1978), discussed in section III.D. infra. 
corollary that the states are not separable economic units. ${ }^{447}$

The material success that has come to inhabitants of the states which make up this federal free trade unit has been the most impressive in the history of commerce, but the established interdependence of the states only emphasizes the necessity of protecting interstate movement of goods against local burdens and repressions. ${ }^{448}$

Our system, fostered by the Commerce Clause, is that every farmer and every craftsman shall be encouraged to produce by the certainty that he will have free access to every market in the Nation . . . .449

But we know already that talk of the Nation as economic unit, talk of free trade, and talk of free access to markets may reflect nothing more than vehemence in the condemnation of protectionism. In fact, the phrase omitted from the first quotation above refers explicitly to customs barriers. The remainder of the sentence begun by the third quotation refers explicitly to embargoes and customs duties. And the second and third quotations bracket the long passage I have already quoted that inveighs against export embargoes and that concludes with Ohio pouncing upon its tire industry in retaliation for Michigan's withholding its automobiles. ${ }^{450}$ Like Cardozo before him, whom he quotes at length, ${ }^{451} \mathrm{Jackson}$ is just condemning protectionism in a rhetorically expansive mode. ${ }^{452}$

Let us now consider very briefly the dissents by Black and Frankfurter. Both, as I have mentioned, raise the issue whether the New York Commissioner really had a protectionist purpose. ${ }^{453}$ Fair enough. But beyond that, both dissents would have been better left unwritten. Black attacks Jackson intemperately and accuses him of trying to revive the doctrine of economic due process. ${ }^{454}$ Frankfurter wants to turn the Court into a regulatory agency; he lists almost a page of questions about the workings of the dairy industry that he

447. 336 U.S. at $537-38$.

448. 336 U.S. at 538 .

449. 336 U.S. at 539 .

450. Quoted in text at note 440 supra.

451. 336 U.S. at 532-33, 538. 84.

452. For similar claims about what Jackson is doing in Hood, see Sedler, supra note 3, at 983 -

Incidentally, another famous source of national economic union rhetoric from Jackson is his concurrence in Duckworth v. Arkansas, 314 U.S. 390, 400-02 (1941) (Jackson, J., concurring). There is no issue of discrimination in Duckworth, so Jackson cannot be merely condemning protectionism in his high-flown prose. But what was at issue in Duckworth was an Arkansas regulation requiring a permit to transport liquor through Arkansas (in this case, from Illinois to Mississippi). If we read Jackson's opinion with this background in mind, it seems clear that what bothers Jackson is the majority's nonchalance in upholding a state regulation of goods in transit. And Jackson is quite right to think that that is a special sort of issue. Cf. section II.F. supra. So again, we have extreme rhetoric in support of a narrow, reasonable claim.

453. See materials cited in note 434 supra.

454. 336 U.S. at 562-63 (Black, J., dissenting). 
needs answers to before he would see fit to decide the case. ${ }^{455}$ And, remarkably, both Black and Frankfurter question whether even an actual protectionist purpose should invalidate the Commissioner's order. Black announces that if he had his way he would hold that the commerce clause does not prohibit even explicit discrimination against interstate commerce; he would review such discrimination under the equal protection clause (presumably applying the minimum rationality standard). ${ }^{456}$ As to Frankfurter, he apparently wants to overrule Pennsylvania v. West Virginia, ${ }^{457}$ or at least to hold that it does not apply to milk. ${ }^{458}$ It is a pity Jackson does not speak directly to the possibility the dissents raise that the Commissioner was pursuing a neutral anti-competitive policy. But Jackson may well have thought such dissents as these deserved no response.

I cannot resist mentioning one last point of agreement between Black and Frankfurter. Given my evaluation of their contributions to Hood, I would not think of actually relying on them for any proposition - but for what it is worth, Black and Frankfurter agree that Jackson is not balancing. ${ }^{459}$

\section{A Post-Pike Survey: Filling in the Gaps}

I make no claim to encyclopedic coverage of the commerce clause case law. But to offer a semblance of coverage, and perhaps to reassure the reader that my interest in old cases has not made me overlook important recent developments, I shall now conduct a rapid survey of all the movement-of-goods cases decided by full opinion since Pike $v$. Bruce Church, Inc. that I have not already discussed. ${ }^{460}$ With one

455. 336 U.S. at 573-74 (Frankfurter, J., dissenting).

456. 336 U.S. at $551 \mathrm{n} .2$ (Black, J., dissenting).

457. 262 U.S. 553 (1923).

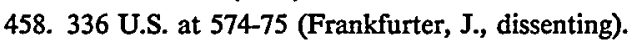

459. 336 U.S. at 555 (Black, J., dissenting); 336 U.S. at 564 (Frankfurter, J., dissenting).

460. The cutoff date for my survey is February 26, 1986. (A last-minute comment on BrownForman, from June 1986, is appended at the end of this note. And there is a footnote further on (note 465 infra) on Maine v. Taylor, also from June 1986.) Post-Pike movement-of-goods cases I have already discussed are Hunt v. Washington State Apple Advertising Commn. (section III.A.); Exxon Corp. v. Maryland and Minnesota v. Clover Leaf Creamery Co. (both in section III.B.); Allenberg Cotton Co. v. Pittman (section II.F.); and, in a brief footnote, Tuscan Dairy Farms, Inc. v. Barber (a memorandum opinion) (section III.C., note 438). I have also discussed to varying degrees a number of post-Pike non-movement-of-goods cases: Commonwealth Edison Co. v. Montana (sections II.D., II.F., III.B.4., and III.C.2.); Kassel v. Consolidated Freightways Corp. and Raymond Motor Transportation, Inc. v. Rice (both in section II.F., Kassel also in sections II.D. and II.C., note 132); and all the state-as-market-participant cases (in section II.G.).

In Brown-Forman Distillers Corp. v. New York State Liquor Auth., 106 S. Ct. 2080 (1986), the Court struck down a New York law requiring distillers to announce the price at which they would sell liquor to New York wholesalers in a future month and requiring the distillers also to affirm that no lower price would be offered during that month to any wholesaler anywhere in the United States. This prospective affirmation law was held to violate the commerce clause "on its 
exception, every law that was invalidated discriminated against interstate commerce explicitly or in avowed purpose.461 So most of what the Court was doing was straightforward suppression of obviously protectionist legislation. Some of the cases involved interesting wrinkles, which I shall comment on briefly as we go. But nothing has happened in the past fifteen years that casts doubt on the conclusions suggested by our discussion up to this point.

The most interesting and important of the post-Pike cases that we have not already discussed at length is City of Philadelphia v. New Jersey. ${ }^{462}$ Speaking through Justice Stewart, the Court struck down a New Jersey statute that effectively closed New Jersey landfills to solid or liquid waste from outside the state.

Of greatest general significance is the Court's clear recognition that protectionist motivation of any feature of a statute makes the statute unconstitutional. Stewart says it is unnecessary to decide whether the purpose of the statute as a whole is primarily to preserve New Jersey's environment or primarily to make landfill space cheaper for residents of New Jersey. Even assuming the general purpose is environmental, New Jersey cannot place the burden of achieving its environmental goal solely on the shoulders of foreigners while exempting their local competitors. ${ }^{463}$

face." 106 S. Ct. at 2084, 2088. The Court's opinion is unsatisfactory in various ways, but one thing is clear: there is no hint of balancing. The New York law is criticized both as embodying protectionist purpose ("While a State may seek lower prices for its consumers, it may not insist that producers or consumers in other States surrender whatever competitive advantages they may possess." $106 \mathrm{~S}$. Ct. at 2085 (citations omitted)) and as extraterritorial. Indeed these two grounds of criticism, which ought to be kept separate, are run together. Although it would be convenient for me simply to embrace the Court's conclusion on anti-protectionism grounds, I am unwilling either to endorse or to reject the Court's conclusion without more discussion than is possible here. The question just what New York's purpose was, and whether it was really to improve the competitive position of local consumers, is more complex than it appears. I do, of course, agree with the Court that the anti-protectionism theory is part of the right approach. As to the extraterritoriality theory, that is also a proper approach, though again I am unable to endorse the Court's discussion as it stands. However, the extraterritoriality theory is not a commerce clause theory (even though the Court says it is), for reasons I discuss in connection with Edgar v. MITE Corp. in the text below.

461. The one exception is Edgar v. MITE Corp., 457 U.S. 624 (1982) (discussed in this section).

462. 437 U.S. 617 (1978).

463. 437 U.S. at 626-27. Compare my discussion of Philadelphia v. New Jersey and of the "any feature" rule in connection with the revenue tariff in subsection II.A.1. (text at notes 6062).

It is perhaps worth noting that elsewhere in the opinion Stewart says "simple economic protectionism" is subject to a "virtually per se rule of invalidity." 437 U.S. at 624 . Since I claim that protectionism is absolutely forbidden, I should comment on why Stewart says "virtually." One possible reason, of course, is mere caution; when one's statements are authoritative, qualification becomes a refiex. Two further reasons involve the vagueness of the word "protectionism" in ordinary language. Stewart could be referring to mere explicitness, which we know is only virtually per se illegal. But even if Stewart is referring to protectionist purpose, remember that such purpose is not absolutely forbidden unless we have stipulated independently that we are ignoring 
The Court also correctly decides that the New Jersey statute cannot be upheld on the authority of the old quarantine cases. ${ }^{464}$ There are two reasons. First, although the quarantine cases indicate that a law can be valid despite being an explicit import embargo, there is always an implicit assumption in those cases either that the problem the quarantine is aimed at (say, a disease of cattle) simply does not exist locally, ${ }^{465}$ or else that local measures for control and suppression of the problem are in force that are generally comparable in their impact to the embargo on imports. There was no suggestion in Philadelphia v. New Jersey that New Jersey had done anything to discourage the internal creation of waste or to minimize the internal transportation of waste.

Second, and even more important, the easy assumption that quarantines are permissible depends on an implicit belief that disposal of unwanted goods is not a problem. Until recently the popular consciousness, the economic and technological consciousness, and the judicial consciousness took it for granted that when an object lost its value, it evaporated. We toss it in the garbage, we toss it in the ocean - but when we no longer want it, getting rid of it is easy. We have recently learned, of course, that getting rid of it may not be easy. Disposal has become a problem. As a result, resources that play a role in the disposal process (such as landfill space) have suddenly become scarce.

Landfill space is now a valuable commodity, and it is a commodity used in a special way. Instead of buying it and taking it off to one's home or one's factory for consumption or further transformation, one uses landfill space by bringing something else, one's waste, to it. So, a quarantine on the import of waste becomes in effect an embargo on the export of landfill space. Explicit export embargoes, we know, are virtually per se illegal; and it does not matter to that illegality whether the (privately owned) landfill space is regarded as a natural resource or as the product of economic development.

We should notice that there are many things New Jersey can still

cases involving the state as market participant (or other cases where protectionist purpose is allowed by part (b) of my definition of protectionism). Stewart simply is not speaking with a precise meaning when he refers to "simple economic protectionism." My claim that protectionism is absolutely forbidden depends on my more-than-ordinarily precise definition of protectionism.

464. 437 U.S. at 628-29.

465. For a recent case of this type, see Maine v. Taylor, 106 S. Ct. 2440 (1986), upholding a Maine quarantine on the import of live baitfish which was designed to protect Maine's unusually pristine and fragile environment from nonnative species and parasites. Even Justice Stevens' lone dissent raises only the issue of how strong should be the presumption of bad purpose triggered by the explicit state-line discrimination in the Maine statute. 
do to slow the use of its landfills and to protect itself from the dangers of solid and liquid waste. It can tax the consumption of landfill space. ${ }^{466}$ It can tax and regulate (evenhandedly) the internal transportation of waste. (This might technically produce a transportation case, under my classification of dormant commerce clause cases, but evenhanded taxation or regulation designed to reflect the nonmarket costs and to minimize the dangers of waste transporting would surely be upheld.) In my opinion, New Jersey could set out measures for discouraging the generation of waste and could deny access to the landfills to entities, local or foreign, that did not comply with these measures. If New Jersey then legally required compliance with these waste reduction measures throughout New Jersey, all New Jersey residents would have access to the landfills, along with foreigners who took similar measures to stop generating waste. (My suggestion that New Jersey might condition access to landfills on adoption of waste reduction measures will raise eyebrows and will attract the complaint that as applied to foreigners such legislation would be impermissibly extraterritorial. I think not. In any event, it is not the only thing I have suggested New Jersey could do. It is only, in some respects, the best thing they could do.)

Two quick final points: In deciding Philadelphia v. New Jersey, the Court implicitly reaffirmed that protection of local consumers counts as protectionism. The Court also implicitly recognized that municipal governments, who are important purchasers of landfill space, are in economic competition with each other as consumers of landfill space even though from the point of view of their residents they are performing a governmental function.

Now let us consider Great Atlantic \& Pacific Tea Co. v. Cottrell, ${ }^{467}$ in which the Court struck down Mississippi's "reciprocity" requirement with regard to milk. Mississippi forbade the sale in Mississippi of milk from other states unless those states accepted Mississippi Grade A milk for sale there.

The reciprocity requirement may not sound like a bad thing. Voluntary reciprocity is undoubtedly a good thing; and it might seem that Mississippi's object is merely to expand trade, not to restrict it. In order to see why Mississippi must not be allowed to impose reciprocity unilaterally, we must consider what might be going on (as we did in analyzing Baldwin).

Imagine that Mississippi's milk standards are lower than Louisi-

466. Cf. Commonwealth Edison Co. v. Montana, 453 U.S. 609 (1981).

467. 424 U.S. 366 (1976). 
ana's (in practice, whether or not on paper). Louisiana Grade A milk fully satisfies Mississippi's standards, but Mississippi Grade A milk does not satisfy Louisiana's standards. Now, since Louisiana milk is healthy by Mississippi standards, there is no ground on which Mississippi can properly refuse Louisiana milk. But since Mississippi milk does not meet Louisiana standards, Louisiana is perfectly within its rights in refusing Mississippi milk. So long as Louisiana's standards are not adopted or manipulated for the purpose of excluding foreign milk, Louisiana may set its health requirements as it will. (And if Louisiana's purpose is simply to exclude foreign milk, then Mississippi's remedy is to sue Louisiana, as Justice Brennan pointed out. ${ }^{468}$ ) Now, if Mississippi can enforce its reciprocity requirement, then either producers of healthful milk in Louisiana will be shut out of the Mississippi market, or else Louisiana will be compelled to lower its standards for milk from Mississippi. Mississippi should not be able to force on Louisiana such a choice.

Mississippi's threat to exclude Louisiana milk from Mississippi unless Mississippi milk is accepted in Louisiana cannot be defended on the ground that Mississippi wants its demand for acceptance of Mississippi milk in Louisiana to be complied with and is therefore merely trying to expand trade. ${ }^{469}$ In the first place, we do not actually know that Mississippi wants its demand to be complied with; possibly Mississippi is happier with the excuse to exclude Louisiana milk that Louisiana's noncompliance gives it. In the second place, whether Mississippi wants compliance or not, it is a good general rule that a state may not threaten what it may not do (in this case, exclude healthful milk originating in Louisiana). Finally, and most importantly, even if Mississippi wants the demand to be complied with, Mississippi's purpose is still protectionist: Mississippi is attempting to improve the competitive position of Mississippi milk producers vis-àvis foreign producers by gaining access for Mississippi producers to a market (in Louisiana) that the quality of their milk does not entitle them to enter. To be sure, protectionism is normally aimed at preserving home markets for local producers, as opposed to shoehorning local producers into foreign markets. There are not many techniques for forcing locals' interests in foreign markets. ${ }^{470}$ But reciprocity requirements are such a technique. When a coercive technique appears by

468. 424 U.S. at $379-80$.

469. This suggestion is found in Smith, supra note 3.

470. State-sponsored advertising and quality control requirements, as discussed in section II.G. supra, are techniques that can have an impact in foreign markets. But they are not coercive in the same way that tariffs and the like are. 
which a state can pursue local preference in regard to foreign markets, use of the technique is no less objectionable just because the market in question is foreign.

In Sporhase v. Nebraska ex rel. Douglas ${ }^{471}$ the Court struck down a Nebraska law that conditioned withdrawal of local groundwater for transportation across state lines on the destination state's granting reciprocal rights of withdrawal and transportation into Nebraska. Insofar as Sporhase stands for any doctrine at all, it merely reiterates a strong presumption against reciprocity requirements. ${ }^{472}$ Beyond that, the Court only temporizes, sensibly reluctant to dive headlong into the complexities of water law. As Rehnquist points out in his dissent, even though Nebraska technically loses, it is not at all clear Nebraska cannot persevere in denying Sporhase a permit to export groundwater consistently with the Court's opinion. ${ }^{473}$

There is a genuine threshold issue concerning whether the Nebraska scheme raises a dormant commerce clause problem at all. It is possible to sympathize with both Stevens' answer (for the Court) and Rehnquist's. Stevens wants to insist, rightly I think, that a law is not insulated from dormant commerce clause review just because on its face it is merely a regulation of landowners' use of groundwater. ${ }^{474}$ But Rehnquist may well be right that the facts of this case present no matter for commerce clause review. ${ }^{475}$ There is something in Rehnquist's "two tier" definition of commerce, as it is coming to be called, ${ }^{476}$ even if Rehnquist is too generous to the states in his own applications. The hypertrophied congressional power over commerce knows no limits; but the dormant commerce clause can hardly be thought to embody a completely general nondiscrimination principle applicable to all areas of legal regulation. On its facts, Sporhase may fall outside the proper scope of the clause in its dormant aspect.

At a less abstract level, Stevens and Rehnquist are less in disagree-

471. 458 U.S. 941 (1982).

472. Arguably the Court must be relying on the "no-singling-out" principle, and not on the anti-protectionism principle proper, since there is no market in groundwater and competing users are therefore not economic competitors in the fullest sense. But granting this, the expansion of the anti-protectionism principle that will cover the case is very slight (and need not take us nearly to the full-fledged no-singling-out principle), if we consider (1) that so long as withdrawable groundwater is in short supply there is a direct confiict of interest between various would-be users of the groundwater, and (2) that these various users may want to use the groundwater as an input to an activity in which they are in full market-mediated competition (if they are farmers, say).

473. 458 U.S. at $965 \mathrm{n} .3$ (Rehnquist, J., dissenting).

474. 458 U.S. at $945-54$.

475. 458 U.S. at 963-65 (Rehnquist, J., dissenting).

476. See, e.g., Hughes v. Oklahoma, 441 U.S. 322,326 n.2 (1979). 
ment. Both recognize, for example, that much federal law presupposes that state lines have a significance for water allocation that they do not have in other economic or quasi-economic areas. ${ }^{477}$ And Stevens seems to indicate that without the reciprocity requirement he might uphold Nebraska's still facially discriminatory scheme. ${ }^{478}$ Stevens is not abandoning anti-protectionism. His reasons for suggesting that he might uphold Nebraska's scheme include, in addition to the possibility that water is special, an argument that Nebraska's scheme may not be discriminatory in effect ${ }^{479}$ and also the notion that $\mathrm{Ne}$ braska may be entitled to favor its citizens in granting access to groundwater because state spending on conservation has contributed to the existence of the present supply. 480

In Lewis v. BT Investment Managers, Inc. ${ }^{481}$ the Court invalidated a Florida statute that explicitly discriminated against bank holding companies whose principal operations were outside Florida. ${ }^{482}$ The only shadow of a controvertible issue in the commerce clause analysis was whether this counted as discrimination against foreigners. As Florida pointed out, even a locally incorporated company would be restricted if its principal operations were elsewhere. ${ }^{483}$ The Court correctly decided that "discrimination based on the extent of local operations is itself enough to establish the kind of local protectionism we have identified." 484

As the Court saw, it is not possible to define once and for all what makes a business "local" or "foreign." There are any number of features of businesses that legislatures might use and have used as the basis for forbidden discrimination (place of incorporation, place of headquarters, place of principal operations, place of residence of principal owners, and so on); different forms of discrimination reflect preferences for different classes of local residents (white-collar employees, employees generally, customers, owners, people affected incidentally, or whatever). I do not mean to suggest a direct correspondence between the possible bases of discrimination I have listed and the possible classes of intended local beneficiaries. The point is that local/ foreign discrimination on any particular basis is likely to benefit some

477. 458 U.S. at 956 (Stevens, J., for the Court), 962 (Rehnquist, J., dissenting).

478. 458 U.S. at 955-57.

479. 458 U.S. at $955-56$.

480. 458 U.S. at 957.

481. 447 U.S. 27 (1980).

482. 447 U.S. at 32 n.2.

483. 447 U.S. at 40.

484. 447 U.S. at 42 n.9. 
class of local residents vis-à-vis foreign competitors. Any form of explicit local/foreign discrimination that seems likely to have been adopted in order to advantage some identifiable class of local residents vis-à-vis foreign competitors is objectionable, as the Court in $B T$ Investment effectively recognized.

The principal significance of Hughes v. Oklahoma 485 is that it overruled Geer v. Connecticut, ${ }^{486}$ which had long been moribund for dormant commerce clause purposes. In striking down a law that explicitly prohibited the export for sale of naturally seined minnows, the Court also implicitly reaffirmed what has sometimes been doubted, that favoring local consumers or retailers counts as protectionism quite as much as favoring local farmers or laborers or manufacturers.

In New England Power Co. v. New Hampshire 487 the Court struck down another fully explicit export embargo. The one interesting wrinkle was this: the technology of power distribution in New England made it impracticable to embargo the export of the actual electricity generated by hydroelectric stations in New Hampshire, so the New Hampshire legislature tried instead to compel New England Power to reserve for New Hampshire customers the "economic benefit" (in the form of low prices) of this specially cheap local energy source. Even this subtle (but still totally explicit) embargo could not survive. Incidentally, the Court rejected New Hampshire's claim that Reeves, Inc. v. Stake 488 authorized it to require New England Power to discriminate in favor of local residents because it (New Hampshire) owned the Connecticut River. ${ }^{489}$

Bacchus Imports, Ltd. v. Dias 490 struck down a discriminatory tax imposed by the state of Hawaii. Since the case involves no issue special to taxation and a number of issues of general relevance, I shall discuss it briefly. The tax did not discriminate explicitly by reference to state lines; rather, it exempted from a general excise on liquor two peculiarly local products ( $t i$-root brandy and fruit wine). But it was admitted all around that the purpose of the exemption was to help the local industries because they were local. What was not admitted was that the object of the exemption was specifically to secure a competitive advantage for the local industries. Hawaii claimed foreign liquor producers would not be hurt. So there was a sort of "revenue tariff" is-

485. 441 U.S. 322 (1979).

486. 161 U.S. 519 (1896).

487. 455 U.S. 331 (1982).

488. 447 U.S. 429 (1980).

489. 455 U.S. at 338 n.6.

490. 468 U.S. 263 (1984). 
sue. ${ }^{491}$ But the Court decided, as it had in Philadelphia v. New Jersey, that such subtlety was irrelevant. There was a clear purpose to spare local actors from burdens that were being imposed on the local actors' foreign competitors, even if the overall tax program aimed at an independently permissible goal. That was enough to invalidate the statute.

There were two other points of interest. First, the Court rejected out of hand Hawaii's attempted "infant industry" justification. ${ }^{492}$ Second, the Court held that state protectionism with regard to the liquor industry was not authorized by the twenty-first amendment. ${ }^{493}$ This issue provoked a dissent by Stevens, Rehnquist, and O'Connor. The Court has spoken delphicly on this issue in the past, ${ }^{494}$ and it is not yet able to speak with one voice.

The serious issue in Arkansas Electric Cooperative Corp. v. Arkansas Public Service Commission ${ }^{495}$ was whether federal statutes or regulations preempted Arkansas' attempt to regulate wholesale rates charged by a rural electric cooperative. The Court did, however, consider a commerce clause challenge based on Public Utilities Commission v. Attleboro Steam \& Electric Co. ${ }^{496}$ which was decided in 1927 under the old "direct/indirect" regime. The Court all but overruled Attleboro in the course of rejecting the commerce clause challenge.497 There was no claim that the Arkansas regulation was in any way discriminatory. Speaking for the Court, Justice Brennan noted that protectionism is "the most serious concern" identified in Pike v. Bruce Church, Inc. 498

In Northeast Bancorp, Inc. v. Federal Reserve System, ${ }^{499}$ involving interstate bank acquisitions, the Court recognizes, though strictly speaking it does not hold, that discrimination based on multistate regional lines is forbidden by the commerce clause. 500 This is the converse of the city line discrimination in Dean Milk, and equally objectionable. A state cannot validate discrimination against a protected class (foreigners) simply by excusing some members of the class from the relevant burden. (Michigan could not conserve gasoline in

491. See the discussion near the end of subsection II.A.1 supra.

492. 468 U.S. at 272-73; cf. subsection II.A.3. supra.

493. 468 U.S. at $274-76$.

494. Compare Joseph E. Seagram \& Sons v. Hostetter, 384 U.S. 35 (1966), with Healy v. United States Brewers Assn., 464 U.S. 909 (1983) (mem.), affg. 692 F.2d 275 (2d Cir. 1982).

495. 461 U.S. 375 (1983).

496. 273 U.S. 83 (1927).

497. 461 U.S. at 389-93.

498. 461 U.S. at 394.

499. 105 S. Ct. 2545 (1985).

500. $105 \mathrm{~S}$. Ct. at 2553-54. 
time of shortage by closing gas stations to blacks but excepting blacks with odd numbered license plates.)

The reason the Court does not actually produce a holding on regional discrimination under the commerce clause is that the discriminatory statutes under review were authorized by Congress and are thus upheld under the doctrine of Prudential Insurance Co. $v$. Benjamin. 501

The application of the Prudential doctrine in Northeast Bancorp would be totally unremarkable (Northeast Bancorp is an eight-to-zero decision), were it not for Metropolitan Life Insurance Co. v. Ward, ${ }^{502}$ decided less than three months previously. In Metropolitan Life, a five-to-four decision, the Court did an end run around Prudential, relying on the equal protection clause to invalidate Alabama's congressionally authorized discriminatory taxation of foreign insurance companies.

Whatever one thinks of Prudential v. Benjamin, the opinion and holding in Metropolitan Life are unfortunate. (Consider that the four dissenters are Justices O'Connor, Brennan, Marshall, and Rehnquist, who all sign a single opinion, by O'Connor.) To say that Alabama's discriminatory taxation was not rationally related to Alabama's purposes would be self-delusion or hypocrisy. Beyond that, there is nothing in equal protection doctrine to suggest either that discrimination on the basis of (current) residence involves a suspect classification or that protectionist purpose is illegitimate. Those ideas belong to the privileges and immunities clause of article IV and to the commerce clause. If Congress can authorize a certain discrimination so far as those clauses are concerned, and has done so, Congress' decision should not be upset by inappropriately transferring commerce clause ideas to the equal protection clause. The equal protection clause has been used in the past to shore up breaches in the law of interstate discrimination created by regrettable interpretations of the privileges and immunities clause and the commerce clause (regarding the status of corporations and what is commerce), ${ }^{503}$ but if we can get the privileges and immunities clause and the commerce clause right, the equal protection clause is simply irrelevant. And if we want to reject Prudential, we should say so.

(In suggesting that the idea of anti-protectionism belongs to the

501. 105 S. Ct. at 2554. (Prudential Ins. Co. v. Benjamin, 328 U.S. 408 (1946), is not actually cited.)

502. 105 S. Ct. 1676 (1985).

503. See generally Conard, Federal Protections of the Free Movement of Corporations, in 2 COURTS AND FREE MARKETS, supra note 1, at 363-84. 
commerce clause and not to the equal protection clause, I am not retracting what I said in section II.H. about the ultimate irrelevance of what textual hook we hang a structural argument on. Rather, I am relying on another point I alluded to in section II.H., that once doctrine has developed to a certain degree, ideas come in structured sets; and those structured sets get attached to certain clauses; and to transplant one idea alone risks destroying an important structure - in this case, the association between the idea that protectionism is generally forbidden and the idea that Congress can authorize protectionism if it wants to.)

Cases like Metropolitan Life have ill effects beyond their immediate holdings. For example, when Rehnquist comes to distinguish Metropolitan Life in the equal protection portion of his Northeast Bancorp opinion, he suggests that under the equal protection clause there is a difference between in-state/out-state discrimination, which is illegitimate, and regional discrimination, which is permitted. ${ }^{504}$ This is silly, as Rehnquist is surely aware and as O'Connor points out in her concurrence. ${ }^{505}$ A silly response may be all Metropolitan Life deserves; but there is the danger that someone will now decide this "distinction" Rehnquist makes is relevant to the commerce clause also and will hold that regional discrimination is permitted by the commerce clause (even though Rehnquist began by denying that). Another example, more briefly, of the threat of doctrinal corruption is the unfortunate comments Powell makes in his Metropolitan Life opinion about retaliation. In an attempt to distinguish Western \& Southern Life Insurance Co. v. State Board of Equalization, ${ }^{506}$ Powell virtually says that retaliation is a specially favored purpose. ${ }^{507}$ Cottrell shivers. Let us hope that the lopsided vote of Northeast Bancorp signals the silent interment of Metropolitan Life. ${ }^{508}$

The one case in which the Court struck down an apparently nondiscriminatory statute was Edgar v. MITE Corp. ${ }^{509}$ I say "appar-

504. See $105 \mathrm{~S}$. Ct. at $2555-56$.

505. 105 S. Ct. at 2556 (O'Connor, J., concurring).

506. 451 U.S. 648 (1981).

507. $105 \mathrm{~S}$. Ct. at $1680-81$.

508. A fuller discussion of Metropolitan Life can be found in Cohen, Federalism in Equality Clothing: A Comment on Metropolitan Life Insurance Company v. Ward, 38 STAN. L. REv. 1 (1985). Cohen agrees with me that there is no constitutional source outside the commerce clause and the privileges and immunities clause for a principle forbidding discrimination against foreign businesses (or the people who run them). Id. at 11-12. Cohen defends the result in Metropolitan Life by suggesting that the Court was covertly reinterpreting the McCarran-Ferguson Act, holding that the Act did not authorize state protectionism. Id. at 12-14, 20. If this is what Metropolitan Life stands for (and Northeast Bancorp supports the thesis that it is), then I have no quarrel with the result. But one wishes the Court had been more candid.

509. 457 U.S. 624 (1982). 
ently" nondiscriminatory. One might well make a case that the Illinois take-over statute invalidated by the Court was intended to protect Illinois cities that currently housed corporate headquarters from losing them. But the Court does not rely on that possibility; nor shall I. Indeed, the one Justice who adverts to this aspect of the matter is Powell, whose sympathies are with the state and the cities. ${ }^{510}$

MITE is one of those cases that produce multiple theories, multiple opinions, and a thoroughly fragmented Court. A reasonable response to the opinions (the right response, I think) would be to conclude that the case stands for no doctrine at all; it stands only for a particular result. The reader who takes this view of MITE is invited to skip over my discussion of $M I T E$ and proceed immediately to the concluding paragraphs of this section, which are set off by a row of asterisks.

I feel that I must discuss MITE, however. If one scrutinizes the opinions in MITE and applies standard nose-counting techniques, one can arrive at the conclusion that the Court in MITE relies on a Pikebased commerce clause balancing theory and relies on that theory uniquely. Obviously, I cannot have that. What I want to argue is that if we are going to scrutinize closely enough to argue that the Court relies on Pike, we ought to scrutinize a little more closely, or a little more thoughtfully, still. If we do, the seeming significance of the reliance on Pike will vanish.

The facts are simple enough. Illinois enacted a statute regulating corporate take-overs that was somewhat more restrictive than an already existing federal statute dealing with the same problem (the Williams Act). The Illinois statute, by its own terms, applied to a takeover offer when ten percent of the target company's shares subject to the offer were owned by shareholders located in Illinois, or when the target company met two of the following three conditions: it had its principal executive office in Illinois, it was incorporated in Illinois, or at least ten percent of its stated capital and paid-in surplus were represented in Illinois. ${ }^{511}$ The MITE Corporation had run afoul of the Illinois statute and was challenging its validity.

What is not simple is how the Justices lined up on the various legal issues. The first problem was whether the Court should decide the case on the merits at all. Marshall, Brennan, Rehnquist, and Powell all thought the case should be dismissed as moot. That left five Justices, however, who thought the case should be decided on the merits:

510. 457 U.S. at 646 n.* (Powell, J., concurring).

511. 457 U.S. at 627. 
White, Burger, Blackmun, Stevens, and O'Connor. I shall return presently to the importance of this division.

The principal opinion, certain portions of which constitute the Opinion of the Court, was written by Justice White. White has three different theories (on the merits) about why the Illinois statute is invalid. First, he thinks the Illinois statute is preempted by the very similar federal statute. ${ }^{512}$ Second, he argues that the Illinois statute is invalid because it is an attempt to legislate extraterritorially. The Illinois statute could apply to transactions occurring completely outside Illinois and involving corporations without a single Illinois shareholder. ${ }^{513}$ Finally, White argues on the basis of Pike that the statute is invalid under the commerce clause because the local benefits are too insubstantial to justify the burdens on interstate commerce. ${ }^{514}$

I have spoken as if only White's third theory was a commerce clause theory. White himself characterizes his second theory (on extraterritoriality) as a commerce clause theory also. I think he is mistaken about that. States are forbidden to legislate extraterritorially whether or not the regulation is a regulation of commerce. There is nothing in the text of the Constitution that says this in terms, but the conclusion is an obvious inference from the general structure of the federal system. In other contexts, the Court has located the prohibition on extraterritorial state action in the due process clause. ${ }^{515}$ But the proper way to justify this limitation on states is by reference to the structure of the system as a whole.

To be sure, the absence of a specific textual prohibition on extraterritorial legislation means that one may be tempted, when one is considering an extraterritorial law that is also a regulation of commerce, to say that the commerce clause prohibits extraterritoriality. But this analysis would be mere window dressing, and misleading. The principle involved is not essentially a commerce clause principle at all.

To the extent White speaks any traditional commerce clause language in his discussion of extraterritoriality, it is the language of direct and indirect restraints. ${ }^{516}$ But he can hardly mean to revive the old direct/indirect test in all its generality. In a different way White implicitly recognizes my point about the non-commerce clause ground-

512. 457 U.S. at $630-40$ (opinion of White, J.).

513. 457 U.S. at $641-43$ (opinion of White, J.).

514. 457 U.S. at 643-46.

515. See, e.g., Abrams \& Dimond, Toward a Constitutional Framework for the Control of State Court Jurisdiction, 69 MinN. L. REv. 75, 76-83 (1984) (disapproving of the use of the due process clause).

516. 457 U.S. at 641-43 (opinion of White, J.) ("directly regulates," "direct restraint," "regulate directly"). 
ing of the extraterritoriality argument. Although he refers to the extraterritoriality argument as a commerce clause argument, he distinguishes it unambiguously from the Pike-based argument about excessive burdens on commerce. ${ }^{517}$ In sum, we have three theories, the preemption theory, the extraterritoriality theory, and the Pike theory, of which only the last is really a commerce clause theory.

How do the Justices line up behind White's theories? White himself and Burger endorse all three theories. Blackmun, who also votes to invalidate the Illinois statute, relies only on the preemption theory. ${ }^{518}$ Stevens and O'Connor, who vote to invalidate the statute, eschew the preemption theory, but endorse both the extraterritoriality theory and the Pike theory. ${ }^{519}$ At this point we have five Justices voting to invalidate the law. We have enough votes to dispose of the case. But we do not have any particular theory which could be regarded as the theory of the Court. The preemption theory has three votes (White, Burger, Blackmun), and the extraterritoriality theory and the Pike theory each have four votes (the same four in each case; White, Burger, Stevens, O’Connor).

It turns out, however, that Powell, even though he thinks the case is moot, also votes on the merits once it is clear the case is going to be decided on the merits. ${ }^{520}$ Powell votes for invalidation, and he relies only on the Pike theory.521 It is Powell's vote that makes the Pike theory the one and only theory endorsed by a majority of the Court. Notice that while the Pike theory is the only theory endorsed by a majority of the Court, Powell is the only Justice who relies only on the Pike theory. Everyone else who addresses the merits endorses some other theory for invalidation instead of or in addition to the Pike theory. Since Powell's vote is not needed to dispose of the case, we would have the same disposition of the case even if the Pike theory were not in the running at all.

I have shown that MITE is a precedent for the Pike theory only by the skin of its teeth; but still, it is a precedent, is it not? Not really; not in the present context. There are two reasons why MITE is substantially weaker as a precedent than it looks already. One reason has to do with the relationship between the Pike theory and the preemption

517. 457 U.S. at 640-46 (opinion of White, J.). The extraterritoriality argument is discussed in Part V.A. of White's opinion; the Pike-based argument is discussed in Part V.B.

518. Of the relevant portions of White's opinion, Blackmun joins only in Parts III and IV (both about preemption).

519. Stevens and O'Connor join in Part V (both A. and B.) of White's opinion, but not in Parts III and IV.

520. 457 U.S. at 646 (Powell, J., concurring).

521. Of the relevant portions of White's opinion, Powell joins only in Part V.B. 
theory. The other reason involves a further fact about Powell's crucial vote.

First, even though the Pike theory is the "theory of the Court" and the preemption theory is not, the two theories are closely intertwined in this case. When the Court strikes down a state statute, appealing to Pike, it always minimizes the claimed benefits of the statute. In this case the way White (speaking for the Court) minimizes the benefits from the Illinois statute is by saying that most of what it accomplishes would be accomplished anyway by the federal statute. ${ }^{522}$ In other words, the state statute is to be credited with only the marginal benefits (if any) that it produces over and above the benefits from the federal statute. This is a defensible mode of application of the Pike test; and it does leave the Pike test theoretically distinct from the preemption test. Still, it makes the Court's Pike analysis depend essentially on the existence of the federal statute covering the same ground. A related point is this: In the absence of the federal statute, the Court would be very poorly situated to decide whether the benefits from the Illinois take-over statute exceed the burdens. This is a question of extraordinary complexity, even as compared to the normal run of possible balancing questions. It is only the fact that the Williams Act is less restrictive than the Illinois statute that gives the Court any real ground for deciding the Illinois statute goes too far..$^{523}$

Even more important in undermining the significance of MITE as an indicator of the continuing vitality of Pike are the circumstances of Powell's vote. All the indications are that Powell would have preferred to uphold the statute. He describes poignantly the costs to communities of losing corporate headquarters, and his explicitly announced reason for relying on the Pike theory is that, of the three theories White advances, it is the least restrictive of state power. ${ }^{524}$

In fact, there is no way to explain Powell's voting on the merits at all except by assuming that he was trying to shape the holding of the case in such a way as to leave the states as much room as possible for passing and enforcing take-over legislation. As I have noted, Powell thought the case was moot. But five Justices wanted to proceed to the merits. Now, it would be one thing for Powell to vote on the merits of the case even though he regarded it as nonjusticiable if a majority of the Court regarded the case as justiciable but were unable to agree on

522. 457 U.S. at $644-45$.

523. Compare the analogous extreme reliance on federal statutory and administrative policy for the "balancing" in Parker v. Brown, 317 U.S. 341 (1943), discussed in subsection III.C.2. supra.

524. 457 U.S. at 646 (Powell, J., concurring). 
a disposition. Powell might then vote on the merits to allow a disposition.525 But Powell's vote on the merits was not needed to secure a disposition in MITE. It was needed (if "needed" is the word) only to produce an official theory for the disposition. All Powell says about why he votes on the merits is that five other Justices have decided to address the merits; and all Powell says about why he prefers the Pike theory is that it is the least restrictive. The only plausible explanation of what he is about is that he is trying to minimize the effect of the case as precedent, so far as that is within his power, by establishing as the theory of the Court the narrowest theory in contention.

But I am arguing in this essay for a narrower interpretation of the commerce clause than is generally assumed to be correct. If Powell is the Justice whose vote makes Pike the theory of the Court; if Powell is the only Justice who relies only on Pike, while everyone else relies in part on some non-commerce clause theory; and if Powell votes only in order to make the holding of the case as narrow as possible; then, I submit, MITE has no weight at all as evidence for the vitality of Pikebased balancing as opposed to some narrower view of what the commerce clause is about.

I have written as if the principal challenge to my anti-protectionism thesis comes from scholars who recommend doing and Justices who claim to do more than just suppress protectionism. If our perspective is that of the whole modern era, this is surely where the principal challenge comes from. But someone might suggest that on the present Court the challenge is from the other side, from Justices who want to do less than suppress protectionism.

Justice Rehnquist (dissenting) voted to uphold explicitly or avowedly discriminatory statutes in City of Philadelphia v. New Jersey, ${ }^{526}$ Hughes v. Oklahoma, ${ }^{527}$ Sporhase v. Nebraska ex rel. Douglas, ${ }^{528}$ and Bacchus Imports, Ltd. v. Dias. 529 Burger joined him twice; 530 O'Connor joined him in both cases decided since her arrival on the Court; 531 and Stevens joined him in Bacchus Imports. As I have mentioned, Stevens showed signs of being willing to uphold facially dis-

525. Compare Justice Rutledge's voting against his own preferred outcome to make a disposition possible in Screws v. United States, 325 U.S. 91, 113 (1945).

526. 437 U.S. 617,629 (1978).

527. 441 U.S. 322, 339 (1979).

528. 458 U.S. 941,961 (1982).

529. 468 U.S. 263, 278 (1984).

530. In Philadelphia v. New Jersey and Hughes v. Oklahoma.

531. Sporhase and Bacchus Imports. 
criminatory legislation in Sporhase, ${ }^{532}$ and Powell was sympathetic to possibly protectionist motivation in MITE. 533 And of course, every Justice but White has voted to uphold explicitly discriminatory behavior in one or another of the "state-as-market-participant" cases. ${ }^{534}$

Even so, the basic anti-protectionism principle is in no danger. Stevens' position in Sporhase I have already discussed; and Powell's position in $M I T E$ is idiosyncratic. As to the state-as-market-participant exception, we saw in section II.G. that there is solid justification for it. Otherwise, the votes to allow protectionism have all been in cases involving natural resources (Hughes v. Oklahoma, Sporhase, and Philadelphia v. New Jersey - although admittedly Rehnquist does not rest squarely on this point in his Philadelphia v. New Jersey dissent), or else in a case involving the twenty-first amendment (Bacchus Imports). Whether the anti-protectionism principle covers natural resources and how it interacts with the twenty-first amendment are questions about the boundaries of the principle. Disagreement about these boundary questions suggests no serious retreat from the principle itself. Remember that Cottrell, BT Investment, and New England Power were all decided unanimously, with Rehnquist's participation in all three and with O'Connor's participation in the last of the three. (Given Stevens' stand on reciprocity in Sporhase, it seems hardly worth mentioning that he did not participate in Cottrell.) New England Power is even something of a natural resources case. In sum, the anti-protectionism principle is alive and well.

\section{E. Why Does the Court Not Preach What It Practices?}

If the Court is really only suppressing protectionism in movementof-goods cases, why does it claim so persistently to be balancing? I cannot be right about what the Court is actually doing unless there is some possible explanation for this discrepancy between word and deed.

I shall attempt to explain the discrepancy, but before I get to specific suggestions, I have two observations. First, about the nature of the discrepancy: $I$ do not think the Justices are intentionally misrepresenting their decision processes. Rather, I think they are imperfectly aware of what they are doing. I have suggested before that judges' intuitive grasp of problems may outstrip their analytic understanding.

532. See text at notes 478-80 supra.

533. See text at note 510 supra.

534. Everybody but Blackmun and White endorsed the state-as-market-participant argument in White v. Massachusetts Council of Constr. Employers, 460 U.S. 204 (1983), and Blackmun wrote the majority opinion in Reeves, Inc. v. Stake, 447 U.S. 429 (1980). 
Second, about the magnitude of the discrepancy: There is less balancing talk in the opinions than the scholarly commentary might lead us to believe. There is no genuine balancing talk in Baldwin or Hood. At the other end of the modern era, there is no balancing talk in Exxon or Commonwealth Edison Co. v. Montana. Nor is balancing talk prevalent before 1970. But since 1970 superficial balancing talk has come into its own, mainly because citation of Pike v. Bruce Church, Inc. has become boilerplate in dormant commerce clause opinions. Of course, even this requires explanation. If the Court does not balance, how could citation of Pike have become boilerplate?

The observation that much of the balancing talk revolves around Pike leads into my first point about why the Court claims to balance. Although the Court cites Pike most prominently in movement-ofgoods cases, the Pike test purports to cover all dormant commerce clause cases, or at least all cases involving state "regulation." In particular, the Pike test clearly purports to cover transportation cases. But as we have seen, there is a place for balancing in transportation cases. So, if the Court wants to state a general test, reference to balancing is not only understandable but necessary. It is unfortunate that the Court has never produced a more refined analysis, recognizing the difference between transportation cases and movement-of-goods cases. But that omission, while not necessary, is still understandable.

The next point is that if the Court did not claim to balance, it would have to admit it was engaged in motive review, which it is obviously loath to do. Although I think the Court is right to engage in motive review, the mere weight of past denials is some explanation of reluctance to admit it now. In addition, the Justices no doubt feel some disinclination to accuse state officials of improper purpose, especially since the issue of purpose, for all that I have argued it is a properly judicial issue, can be difficult.

The Court may even have got itself into a trap regarding motive review. Because the Court has so often denied that purpose is the issue, lower courts have probably been deterred from making findings of bad purpose, ${ }^{535}$ and parties challenging statutes may have deemphasized claims of bad purpose in their litigation strategies. ${ }^{536}$ This means the Court often could not rely squarely on a claim of bad pur-

535. Consider, e.g., the unwillingness of the trial court in Hunt to make an explicit finding of bad purpose. See text at notes 288-89 supra.

536. Justice Black asserts that H.P. Hood \& Sons did not even question the New-York Commissioner's motivation in H.P. Hood \& Sons v. Du Mond, 336 U.S. 525 at 547, 549 (1949) (Black, J., dissenting). 
pose without making the initial finding of fact itself, which may seem particularly uninviting.

If the Court is engaged in motive review but does not want to say so, balancing talk provides an ideal cover. Protectionist effect balancing, and especially weak protectionist effect balancing (with the "clearly excessive" test), comes as close to mimicking motive review as any non-purpose-based test could be expected to come.

Indeed, one could slide between motive review and protectionist effect balancing quite unconsciously. By and large, the evidence that is relevant to one test is the same as the evidence that is relevant to the other. ${ }^{537}$ And motive review itself involves a sort of balancing, namely, the balancing of bits of evidence regarding purpose. There is an important logical difference between interest balancing (where the good and bad effects must be identified by the Court and assigned normative weights before they can be balanced) and evidence balancing (where much the same bits of evidence about likely effects must be assigned epistemological weights as bearing on the question of legislative purpose). But a Justice might easily lose track of this logical difference as he studied a record under the pressure of time and with the primary need to reach some decision.

Aside from the specific resemblance of a certain form of balancing to motive review, balancing talk has the advantages of familiarity and vagueness. Not only is the Pike language now comfortingly familiar; so also is the general idea that constitutional cases are resolved by balancing. The idea is familiar both to judges and to their audience. If the Court announces that it is balancing in some class of cases, it will encounter little pressure from scholars or from the bar to modify or clarify that claim. Instead, scholars and lawyers alike will busy themselves with identifying and persuasively characterizing every imaginable interest so it can go in the balance.

As to the advantages of vagueness, the Court that is engaged in balancing need have no fear of being shown to be definitively wrong, as it might be on the issue of legislative purpose. Also, if the test is balancing, there is less call for deference to lower court findings than if the test is the factual question of purpose. Balancing involves what in another context we call a mixed issue of law and fact. Finally, talk of balancing leaves the Court a permanent loophole. The Court may decide case after case by implicit or all-but-explicit motive review; but as long as it repeats the balancing test, it need never feel completely locked into that framework. I do not claim that the Court is inten-

537. This appears most clearly in the discussion of Hunt in subsection III.A.2. supra. 
tionally maximizing its freedom of action, though it may be. The considerations I mention in this paragraph, like those mentioned previously, can operate unconsciously on the judicial mind.

\section{Envoi}

My picture of dormant commerce clause theory and practice is unevenly realized. I have sketched the broad outlines and filled in some detail, but I have omitted much detail also. If the picture is well conceived, the detail will fall into place. Take up the brush, Reader. See if the blank spaces on the canvas do not almost paint themselves. 